\title{
A FRAMEWORK FOR THE COLLECTION, RETENTION AND USE OF HUMAN BODY PARTS
}

by

Cordelia Mary Thomas

\author{
A thesis \\ Submitted to the Victoria University of Wellington \\ in fulfilment of the \\ requirements for the degree of \\ Doctor in Philosophy \\ in Law
}

Victoria University of Wellington

2006 


\begin{abstract}
Organ transplantation and biotechnological research depend on the availability of body parts, which necessitates the willing involvement of the public. The rapid development of biotechnology has led to a search for an adequate decision-making framework for the acquisition, retention and utilisation of body parts. It has also lead to disquiet about the commercialisation of research with the source being the only participant who is unable to benefit financially. In developing such a framework it is necessary to conceptualise the nature of the interest that individuals have in their bodies.

The principle of autonomy may form a basis for structuring decision-making and weighing conflicting principles. As a society we value autonomy in the sense that a competent adult may make decisions about his or her own health care. The concept is that of an individual separated from others by a wall of rights. This may be of assistance as a basis for formulating competing rights, but this must then be mediated with reference to other principles. In this context this thesis applies the concepts of property interests to the human body.
\end{abstract}

The purpose of this research is to consider selected bioethical issues in an attempt to formulate a principled approach to issues of consent and control over the body and its component parts. It argues that a living person should have a property interest in excised body parts during life. There should also be a property interest in the cadaver that arises at the point of death, which can be passed to the deceased's personal representative, who would be required to deal with the cadaver in accord with the previous instructions of the deceased. However, it does not argue that there are property interests in entire living persons.

It does not suggest that property alone is adequate to resolve the issues, but that it should operate alongside existing concepts such as autonomy, informed consent and privacy. It proposes draft legislation to illustrate the operation of the suggested medico-legal framework.

It recognises that any framework should be respectful of Māori cultural values, in light of the special position of Māori as tangata whenua, as expressed in the Treaty of Waitangi. It argues that the framework allows Māori the freedom to choose collective or individualistic decision-making, in recognition of the diversity of values within the Māori population.

In addition, it considers areas where public policy might determine that the free disposition of this property interest should be restricted to protect vulnerable persons, such as incompetent persons and living organ donors. 


\section{ACKNOWLEDGEMENTS}

I became interested in this area of research some years ago, having read about the experiences of John Moore. I then discussed my ideas with Dr David Collins and was encouraged by his enthusiasm and willingness to assist me to develop a proposal for a thesis. I consider I have been most fortunate in my choice of supervisors, as both Dr Collins and Prof Bill Atkin have been supportive and encouraging.

I would like to thank Dame Joan Metge and Dr Waiora Port for giving helpful advice relating to chapter 5 and Aroha Te Pareake Mead and Sarah Jane Paine for reading and commenting on chapter 5. I would also like to thank Jane Hubbard for her attention to detail.

I would like to thank my family and my colleagues for their encouragement and their willingness to debate issues with me. 


\section{TABLE OF CONTENTS}

\section{INTRODUCTION}

I PURPOSE OF THESIS 1

II STRUCTURE OF THESIS 3

Chapter 1

\section{PROPERTY RIGHTS}

I INTRODUCTION 6

$\begin{array}{lll}\text { A } \quad \text { Work and Skill } & 7\end{array}$

B First Occupancy $\quad 8$

PART I

I THE NATURE OF PROPERTY RIGHTS 9

$\begin{array}{lll}\text { A Reified Perspective } & 10\end{array}$

B Bundle of Rights $\quad 11$

C Natural Rights Theory $\quad 13$

D Labour Theory 14

E Social Utility Theory 15

1 Traditional Utility Theory 16

2 The Economic Utility Theory 16

F Application of Theories of Property Justification 17

1 Gaus 17

2 Munzer $\quad 18$

3 Reed 19

4 Gold 20

5 Radin 21

$6 \quad$ Beyleveld and Brownsword $\quad 22$

G Property in Intact Bodies 24

H Property in Body Parts 25

PART II

$\begin{array}{lll}\text { I } & \text { AUTONOMY } & 27\end{array}$

$\begin{array}{lll}\text { A Principlism } & 27\end{array}$

B Criticisms of Principlism 28

II PROPERTY INTERESTS 29 
A Policy Arguments 29

B Control 31

C Public Trust $\quad 31$

D Informed Consent $\quad 32$

1 Bodily integrity $\quad 33$

2 Dignity 34

$3 \quad$ Chill research? 35

$4 \quad$ Third parties 36

III ARGUMENTS AGAINST A PROPERTY CONSTRUCT 36

A Economic Inefficiency 36

B Commodification of the Person 38

$1 \quad$ Futures market $\quad 41$

C Professional Relationships $\quad 42$

D Altruism and the Common Good 43

IV CONCLUSIONS

Chapter 2

BODY PARTS FROM THE DEAD

$\begin{array}{lll}\text { I INTRODUCTION } & 46\end{array}$

II MODERN SCANDALS 46

A United Kingdom $\quad 48$

B New Zealand 49

C United States $\quad 50$

III PROCUREMENT SYSTEMS 51

A Conscription $\quad 52$

B Presumed Consent 54

C Required Request $\quad 55$

D Mandated Choice $\quad 56$

E Preferred System

IN COMMON LAW PERSPECTIVES ON PROPERTY

A Effect of Framework on Common Law Position 62

\begin{tabular}{ll|l} 
VI QUASI-PROPERTY & 64
\end{tabular}

VII SHOULD PROPERTY IN A DEAD BODY BE RECOGNISED? 65

$\begin{array}{lll}\text { A Societal Changes } & 65\end{array}$ 
B Conflicting Interests $\quad 66$

C Retention of Tissue Samples $\quad 67$

D Respect $\quad 67$

PART II

I PRESENT FRAMEWORK

II COMPARISON BETWEEN THE UNITED KINGDOM HUMAN TISSUE ACT AND THE HUMAN TISSUE BILL

$\begin{array}{lll}\text { A } & \text { Structure } & 72\end{array}$

B Human Tissue Authority $\quad 72$

C Application $\quad 72$

$\begin{array}{lll}\text { D Consent } & 72\end{array}$

E When Consent Required $\quad 73$

F Research $\quad 75$

$\begin{array}{lll}\text { G Surrogate consent } & 76\end{array}$

H Organ donation $\quad 78$

I Commercialisation $\quad 79$

$\begin{array}{lll}J & \text { Philosophical bases } & 79\end{array}$

$\begin{array}{lll}\text { III CONCLUSIONS } & 81\end{array}$

Chapter 3

BODY PARTS FROM THE LIVING

$\begin{array}{lll}I & \text { INTRODUCTION } & 84\end{array}$

II ORGANS AND CELLS

$\begin{array}{llr}\text { A Moore } & 84\end{array}$

$1 \quad$ Policy arguments $\quad 86$

2 Fiduciary duty $\quad 86$

3 Waste 87

$4 \quad$ Interpretation $\quad 88$

B Subsequent US Cases

$\begin{array}{ll}\text { C Canavan Children } & 90\end{array}$

$1 \quad$ Informed consent 91

$2 \quad$ Breach of fiduciary duty 92

3 Unjust enrichment 92

$4 \quad$ Fraudulent concealment 92

5 Conversion 93

$6 \quad$ Misappropriation of trade secrets 93

D Washington University v Catalona 93

E Comment on Cases $\quad 95$

III THE CONTEXT OF THE 
A Collection of Samples $\quad 96$

B European Guidelines $\quad 98$

C “Guthrie” Test Samples 99

D Amendment to the Code 101

E Anonymisation of Samples $\quad 101$

F Res Nullius 102

$\begin{array}{lll}G \quad \text { Waste } & 103\end{array}$

H Adequacy of Informed Consent to Protect Sources 104

I PXE International and the University of Hawaii 105

IV LIVING DONOR TRANSPLANTATION 107

$\begin{array}{lll}\boldsymbol{A} & \text { Gender Issues } & 108\end{array}$

$\begin{array}{lll}B & \text { Informed Consent } & 108\end{array}$

C Compulsion 110

D Ethical Aspects 110

VI CONCLUSIONS 113

A Biological Samples $\quad 113$

B Living Donor Transplantation 115

Chapter 4

PERSONHOOD

$\begin{array}{lll}I & 117\end{array}$

II THE CONCEPT OF A PERSON 118

III AIREDALE NHS TRUST V BLAND 120

IV THE STATUS OF GAMETES AND THE UNBORN CHILD 121

$\begin{array}{lll}\text { A } & \text { Gametes } & 121\end{array}$

B Is an Unborn Child a Person? 124

C Is an Unborn Child Property? 127

D Research Using Embryos 129

$\begin{array}{lll}\boldsymbol{V} & \boldsymbol{D E} \boldsymbol{A T H} & 131\end{array}$

A Development of the Concept of Brain Death 131

B Concerns about Brain Death 134

$\begin{array}{lll}\text { VI CONCLUSIONS } & 136\end{array}$

Chapter 5 
THE MĀORI PERSPECTIVE

\begin{tabular}{|c|c|c|}
\hline $\boldsymbol{I}$ & INTRODUCTION & 139 \\
\hline II & BASIS OF THE MĀORI WORLD VIEW & 140 \\
\hline$A$ & Contemporary Health Model & 140 \\
\hline $\boldsymbol{B}$ & The Relevance of the Treaty of Waitangi & 142 \\
\hline$C$ & Concepts Relating to Human Tissue & 144 \\
\hline 1 & Тари & 144 \\
\hline 2 & Mauri & 144 \\
\hline 3 & Whakapapa & 145 \\
\hline 4 & Kaitiakitanga & 146 \\
\hline III & CONSULTATION & 146 \\
\hline IV & ISSUES OF IMPORTANCE TO MĀORI RELATING & \\
\hline & UMAN MATERIALS & 147 \\
\hline$A$ & Organ Transplantation & 147 \\
\hline 1 & Living donation & 148 \\
\hline 2 & Organs from deceased donors & 149 \\
\hline $\boldsymbol{B}$ & Uses of Biological Materials & 151 \\
\hline 1 & Research & 153 \\
\hline 2 & Genetic modification & 155 \\
\hline 3 & Informed consent & 155 \\
\hline $\boldsymbol{V}$ & GENETIC MODIFICATION & 158 \\
\hline$A$ & The Transgenic Sheep & 158 \\
\hline $\boldsymbol{B}$ & The Transgenic Cow & 158 \\
\hline$V I$ & CONCLUSIONS & 161 \\
\hline
\end{tabular}

Chapter 6

\section{CONTENTIOUS CLASSES OF DONORS}

$\begin{array}{lll}\text { I INTRODUCTION } & 164\end{array}$

II CHILDREN 166

$\begin{array}{llr}A & \text { Competence } & 166\end{array}$

$\begin{array}{lll}\text { B } & \text { Best Interests } & 168\end{array}$

C Substituted Judgment 170

D The New Zealand Legal Position 170

1 The New Zealand Bill of Rights Act 1990

2 International covenants 171

$3 \quad$ Health and Disability Commissioners Code of 
Health and Disability Services Consumers' Rights 171

$4 \quad$ Children of or over the age of 16 years 171

$5 \quad$ Children under the age of 16 years 172

$6 \quad$ Children and families $\quad 172$

$\begin{array}{lll}\boldsymbol{E} & \text { Guidelines } & 173\end{array}$

III ORGAN DONATION BY MENTALLY INCAPACITATED DONORS 175

A Protection of Personal and Property Rights Act 1988

$1 \quad$ Best interests 176

$2 \quad$ Substituted judgment 177

$3 \quad$ Public policy 178

$4 \quad$ Advance directives 178

IV INCOMPETENT PERSONS AND RESEARCH 179

A Children as Research Subjects $\quad 180$

B Incompetent Adults as research subjects 183

$\begin{array}{lll}V & \text { CONCLUSIONS } & 184\end{array}$

Chapter 7

PATENTING OF BIOTECHNOLOGICAL INVENTIONS

$\begin{array}{lll}\text { I INTRODUCTION } & 185\end{array}$

II INTELLECTUAL PROPERTY 186

A Techniques used in the Manipulation of Living Organisms 186

B Patent Requirements 187

C Review of the Patents Act 188

$1 \quad$ Human being 190

C Opposition to Patenting of Genes 191

$1 \quad$ Inventive step 191

2 Novelty 192

3 Usefulness 193

$4 \quad$ Products of nature 193

$5 \quad$ Analogy with drug patenting 195

$\begin{array}{lll}\text { III PROFIT } & 195\end{array}$

IV MULTIPLE PATENTS 195

V RESEARCH OR TREATMENT USE 196

$\begin{array}{lll}\text { VI POTENTIAL SOLUTIONS } & 197\end{array}$

$\begin{array}{lll}\text { A Licensing } & 197\end{array}$ 
B Inventorship 198

C Joint inventorship 198

D Causation 199

VII PROPERTY RIGHTS 199

$\begin{array}{ll}\text { A Contribution approach } & 201\end{array}$

B Patent unenforceability 201

C The Shop Right Doctrine 202

D Contract 202

VIII GLOBALISATION 204

$\begin{array}{lll}\text { IX CONCLUSIONS } & 205\end{array}$

Chapter 8

FRAMEWORK

$\begin{array}{lll}\text { I INTRODUCTION } & 207\end{array}$

II PROPERTY INTEREST 208

III NON-THERAPEUTIC USE OF TISSUE 209

$\begin{array}{llr}\text { A Living Sources } & 209\end{array}$

1 Incompetent adults 211

$2 \quad$ Children and consent $\quad 212$

B Powers to Dispense with the Need for Consent 214

$1 \quad$ Public interest 214

2 Third parties $\quad 214$

C Research Use of Existing Holdings 215

D Future Unspecified Research 216

$\begin{array}{ll}\text { E Anonymisation } & 218\end{array}$

$\begin{array}{ll}\text { IV DEAD BODIES } & 219\end{array}$

A Appointment of Representative 219

$\begin{array}{lll}\boldsymbol{B} & \text { Title } & 221\end{array}$

C Information to be Provided at the Time of Appointment 221

D Point at which Appointment is Effective 221

E Duties of Representative 222

F Priority List 222

G Consent 223

H Preservation of the Body $\quad 224$

$\begin{array}{lll}\text { I Sanctions for Breach } & 225\end{array}$

$\begin{array}{lll}\text { V ORGAN TRANSPLANTATION } & 226\end{array}$

A Enforcement of the Wishes of the Deceased 226

B Person Lawfully in Possession 227 
$\begin{array}{lll}\text { C Relatives } & 228\end{array}$

$\begin{array}{lll}\text { VI LIVING DONOR TRANSPLANTATION } & 229\end{array}$

$\begin{array}{lll}\text { A Children } & 231\end{array}$

VII POST-MORTEMS AND RETENTION OF TISSUE

VIII FUTURE-PROOFING 231

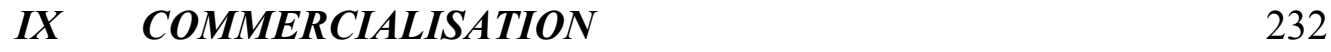

A Work and Skill $\quad 232$

B Sale of Organs 233

C Tissue 234

D Reimbursement of Expenses 235

$\begin{array}{lll}\text { IX INSTITUTIONS } & 235\end{array}$

A Ethics Committees 235

B Constitutional Justification 236

VII CONCLUSIONS 239

CONCLUSIONS 240

BIBLIOGRAPHY 246 


\section{INTRODUCTION}

The issue I find so bizarre is that these guys could claim as theirs something that was totally mine, genetically mine. They could claim it for themselves - claim ownership - but I couldn't. ${ }^{1}$

\section{PURPOSE OF THESIS}

The collection and use of human body tissue has evoked concerns, from eighteenth century practices of dissection, through to twentieth century organ transplantation and twenty-first century cell line creation and cloning. The inability of the law to keep pace with technological advances leads to fears regarding the ownership and use of such tissue. As was observed in 1970 by Windeyer J, the law marches with medicine, "but in the rear and limping a little."2

Both private and public value can be attached to the body and its parts. The private value of the body relates to a person's sense of self. As individualism has increased, the body has acquired a moral significance, as an extension of the "self". Autonomy has come to be the primary concept in bioethics, reflecting the notion of each person as a separate entity. Andrews and Nelkin argue that to be psychologically healthy, people need to experience both self-agency, which is the ability to control what is done to their bodies, and self-coherence, which is the ability to maintain nonfragmented whole bodies. ${ }^{3}$ Thus, they assert that taking or using tissue, without the individual's knowledge or consent, can compromise psychological development and emotional well-being.

The public values relate to the economic and social benefits from organ transplantation and the technological advances achieved by utilising body parts in research. The biotechnology revolution "has become modern alchemy, aiming to transmute diseased biological material into gold, and to find the panacea of human genetic illness." 4 Market forces and scientific advances in medical research have merged, creating tension between the profit-based goals and expectations of the market, the scientific expectations of freely shared knowledge, and the expectation that sources donate body parts without compensation. This has led to equity considerations in apportioning the financial and therapeutic benefit from such discoveries.

There are great benefits for individual recipients from transplantation and states wish to implement policies that will result in the harvest of the greatest possible number of organs. ${ }^{5}$ These policies may challenge autonomy because consent of the

\footnotetext{
${ }^{1}$ Comments of John Moore, reported in Adam Stone "The Strange Case of John Moore and the Splendid Stolen Spleen" (1996)

$<$ http://socrates.berkeley.edu:4050/moore.html> (last accessed 10 September 2004).

${ }^{2}$ Mount Isa Mines Ltd v Pusey (1970) 125 CLR 383, 395 HCA (Windeyer J).

${ }^{3}$ Lori B Andrews and Dorothy Nelkin "Whose Body Is It Anyway? Disputes Over Body Tissue in a Biotechnology Age" (1988) 351 Lancet 53, 54.

${ }^{4}$ Anne Nichols Hill "Note: One Man's Trash is Another Man's Treasure, Bioprospecting: Protecting the Rights and Interests of Human Donors of Genetic Material” (2002) 5 J Health Care L \& Pol'y 259.

${ }^{5}$ In 2005, New Zealand had only 29 organ donors- the lowest figure ever: Give Life "Organ donor Rates for 2005 Worst Ever" Scoop Independent News 11 January 2005 <www.scoop.co.nz> (last accessed 12 January 2006).
} 
source may be lacking, in some strategies, such as presumed consent or where the views of the relatives are allowed to prevail over the wishes of the deceased.

Organ donation and research using human biological materials are dependent for their continued viability on the participation of the public. As the public and private values of body parts may conflict, the purpose of this thesis is to devise a legal framework that reconciles such conflicts, while encouraging and supporting organ and tissue donation. The rights of living persons over their excised biological materials and their prospective rights to control the disposition of their bodies after death raise complex legal issues and recent rapid scientific developments relating to the human genome necessitate articulation of the legal rights of the person from whom the biological material was harvested (the "source").

The fundamental question relates to which legal principles might best protect these interests. Some commentators argue that the law should recognise that sources have property rights either in their whole bodies or in excised body parts. ${ }^{6}$ Others argue that such recognition is unjustified at law, or could have a chilling effect on research. $^{7}$ This thesis is intended to relate this ongoing debate to New Zealand jurisprudence and, in particular, to suggest a legislative framework that would encompass property rights alongside present provisions relating to informed consent and privacy, to allow sources to control the collection, retention and use of body parts and share in the profits derived from them. This thesis makes an original contribution to these conversations by demonstrating draft legislation. ${ }^{8}$ Supporters of property rights have not generally considered how their proposals would be put into effect, particularly in the New Zealand context. Although they have acknowledged the need to ensure that New Zealand law respects Māori values and customs, commentators have not considered how this might be achieved.

Property rights would enable sources who allege that their body parts were misappropriated to have civil remedies, such as conversion, and they would be able to enter into contractual relationships with researchers to share in the profits made from patenting of inventions based on their body parts. However, it is argued that asserting that sources have a property interests in excised body parts will not, in itself, solve the concerns that have lead to this thesis. For example, it is argued that property must exist alongside regulated consent structures and that vulnerable persons may need particular legislative protections.

In 2004, the Ministry of Health reviewed the use of human tissue for therapeutic and non-therapeutic purposes and on 7 November 2006 the Government introduced the Human Tissue Bill (HTB). ${ }^{9}$ This thesis argues that the bill has

\footnotetext{
${ }^{6}$ B Dickens "The Control of Living Body Materials" (1977) 27 U Toronto L J142, 183; G Dworkin and I Kennedy "Human Tissue: rights in the Body and its Parts" [1993] 1 Med L Rev 291, 311; C Hammond "Property Rights in Human Corpses and Human Tissue: The Position in Western Australia" (2002) 4 U Notre Dame Australia L Rev 97, 113.

${ }^{7}$ L Skene "Proprietary Rights in Human Bodies, Body Parts and Tissue" (2002) 22 Legal Studies 102, $123-127$.

${ }^{8}$ Chapter 8 contains selected sections of a proposed statute.

${ }^{9}$ The Human Tissue Bill provides a framework for regulating the collection, storage and use of tissue and organs, primarily from the deceased. It also regulates trading in tissue, export and import of tissue, and the use of tissue for non-therapeutic purposes (e.g. audit, anatomical examination, research and post mortem). The Bill is discussed in chapter 2.
} 
substantial weaknesses and does not adequately protect the interests of sources. It provides for a complex consent regime, with no protection of the right of a person to veto any use of their cadaver, should their relatives be willing to give consent.

This thesis argues that New Zealand law should recognise that sources have property rights over excised body parts and that a property interest in the cadaver arises at death. This interest would pass to a representative, and be administered according to the previously expressed wishes of the deceased person. It is argued that the aims of protecting the interests of sources and encourage their participation in organ donation and research will only succeed if the framework respects the interests of living and previously living persons, even if such respect conflicts with the wishes of families.

This thesis is grounded in medico-legal concepts and, despite the emphasis on property, it is not intended to develop a new concept of the law of property. The thesis does not focus on the regulation of medical and genetic information, or whether the law regards information as property. Rather, it is concerned with appropriate medico-legal structures for the collection, retention and use of body parts and cadavers. These recognise that even if body parts are treated as property, they are a special category and that the law must also incorporate concepts of autonomy and informed consent. Consequently, this thesis suggests draft legislative provisions to demonstrate the practical application of the proposals.

\section{STRUCTURE OF THESIS}

A property right equates to the right to make decisions about matters such as the right to use, the right to sell, and the right to destroy the item. Property rights are both positive in that they allow actions such as consumption or destruction of the item and negative in the sense that they permit the holder of the property right to prevent others from doing things- such as using the item. Thus, property rights to the body or body part result in the authority to make decisions about disposition or use, while protecting the rights of the parties and providing remedies where appropriate. As stated, commentators have argued for and against property rights in human body parts and some of these arguments will be traversed in this thesis. However, proponents of a property approach have not generally teased out how such a construct could be combined with structures to respect autonomy and the commonly accepted concept of informed consent, as is intended here.

Chapter 1 establishes the theoretical foundation for the thesis and introduces property theory as applied to body parts. It argues that there is no property interest in the whole body, but that there is such an interest in excised body parts and the cadaver after death. It considers how body parts may be transformed into things capable of being subject to property rights. It discusses whether informed consent is sufficient to protect sources, interests and concludes that, although vital, it does not resolve the issue of ongoing control over body parts or the sharing of profits from products and services made from them. The chapter introduces arguments for and against property interests in body parts.

Chapter 2 considers the development of the no-property rule with respect to dead bodies. It explores various regimes for consent to organ donation after death. 
The problems with the present legislation, the Human Tissue Act 1964, are outlined. The issues considered in this thesis have been addressed, to some extent, in the United Kingdom in the Human Tissue Act 2004 (UKHTA). It is argued that the UKHTA is philosophically grounded in property rights and interests, even though this is not acknowledged in the Act. The UKHTA is considered and contrasted with the proposals for legislation in the HTB. ${ }^{10}$ It is argued that the HTB does not adequately address many of the issues in this area and that the proposed framework is a more effective solution.

Chapter 3 explores materials excised from living bodies and, as there has been minimal litigation in this area in New Zealand, judicial decisions from the United States and United Kingdom are considered and analysed. It is argued that utilisation of tissues and samples for research is a societal good, but that participation in research should not be a matter of conscription. The research use of biobanked material is considered and also whether sources should be able to consent to unspecified future uses of their body parts.

Additionally, this chapter explores living donor transplantation and commentators' arguments that such donors should be protected in light of their vulnerability to coercion. Donors would have property interests in their organs once the organs were excised, which they could agree to pass to the recipient. That agreement would be expressed by way of the donor's informed consent. However, the chapter concludes that it is impossible to ensure that such consent is freely given, other than by way of robust procedures at the time of consent. It is argued that the property construct is applicable to living organ donation, because it provides a means for donors to control the collection and use of donated organs and provides remedies for misuse.

As the thesis argues that persons have property interests in excised body parts it is necessary to explore when this interest arises, to establish the parameters of the thesis. Consequently, chapter 4 considers the status of embryos and the unborn child. Similarly, as the framework provides that a property interest in a cadaver arises at death, the nature of death is explored, particularly with regard to brain death.

This thesis is primarily concerned with a framework for New Zealand. Consequently, chapter 5 explores whether the proposed framework is sufficiently respectful of Māori cultural values, in light of the special position of Māori as tangata whenua, ${ }^{11}$ as expressed in the Treaty of Waitangi. It will be argued that the human body is a taonga ${ }^{12}$ and, as such, any legislative framework must be respectful of the strongly held tikanga ${ }^{13}$ around human bodies and body parts. Māori beliefs about whakapapa $^{14}$ suggest that, to some Māori, individualistic decision-making is inappropriate. It will be argued that the proposed framework is sufficiently flexible to

\footnotetext{
${ }^{10}$ Ministry of Health Review of the Regulation of Human Tissue and Tissue-based Therapies (Ministry of Health, Wellington, 2004) <http://www.moh.govt.nz> (last accessed 23 March 2006) and the Human Tissue Bill 2006..

${ }^{11}$ Local people, hosts, indigenous people of the land - people born of the whenua, i.e. of the placenta and of the land where the people's ancestors have lived and where their placenta are buried.

12 Treasure.

${ }^{13}$ Customs or culture.

${ }^{14}$ Geneology.
} 
allow an individual to choose either collective or individualistic decision making. However, it argues that it is inappropriate to impose any particular cultural framework on individuals, in light of the diversity of Māori and the pluralistic nature of New Zealand society. With regard to research use of body parts, it is argued that cultural values are more appropriately considered at the stage of research approval, by involved collective groups such as whānau, ${ }^{15}$ iwi, ${ }^{16}$ or hapu ${ }^{17}$ having a wānanga ${ }^{18}$ around the broad purposes and processes of the research, before any individuals are approached to provide research materials. New Zealand differs from other jurisdictions, in that Māori values are valued and respected, but there has been scant academic debate considering how Māori values about body parts might fit into a western individualistic paradigm. It is argued that the framework proposed in this thesis advances existing writings, by adding an original dimension in the form of practical solutions.

Children and mentally incompetent persons may have impaired ability to make or communicate their decisions. Although they are potential sources of organs and body parts, they may be unable to consent to such use. Chapter 6 considers the present New Zealand legislation with regard to incompetent persons and the consequences of the accommodation of property rights into such law. It concludes that parents may have a conflict of interests when making decisions about organ donation within the family and recommends that such decisions be overseen by the Family Court or the recommended Human Tissue Authority.

Patenting biotechnological inventions encourages the investment of the capital necessary to fund research, but it may result in loss of control by human sources over the uses of their body parts and may reduce the affordability of resultant tests and treatments. The decision in Moore $v$ Regents of the University of California ${ }^{19}$ allowed the biotechnology industry to utilise and profit from genetic raw materials, while failing to adequately protect Moore's autonomy, or provide any incentive for others to allow research using their body materials. Chapter 7 argues that application of the property construct would provide a means for the human sources of biological material to participate in the profits resulting from the patenting of biotechnological inventions and considers potential approaches to achieve this.

Chapter 8 develops a proposed framework for collecting, retaining and utilising body parts. It suggests draft sections to demonstrate the practical effect of the framework. The framework proposes that living persons have inchoate property rights in their bodies. Once body parts are excised, the source has a property right in those parts. If conditions are imposed by the source, the doctor or researcher obtains limited possessory rights to use the body parts. It is accepted that some people may be indifferent as to the fate of such parts and may either impliedly or expressly abandon them, in which case property will pass to the doctor or researcher who obtains

\footnotetext{
${ }^{15}$ Family group.

${ }^{16}$ Tribe.

${ }^{17}$ Clan, tribe or sub tribe.

${ }^{18}$ Discussion.

${ }^{19}$ Moore $v$ Regents of the University of California (1988) 249 Cal Rptr 494, 215 Cal App 3d 709 (App Div) modified (1990) 51 Cal 3d 120, (1990) 271 Cal Rptr 146, (1990) 793 P 2d 479 cert denied, (1991) 499 US 936. This case is considered in detail in chapter 3.
} 
possession and asserts ownership. It argues that a property right in a cadaver should arise briefly at the point of death, then pass to the representative of the deceased.

Once a body part was reintegrated into the body of another, the source's rights would be extinguished and the part become part of the recipient's body and thus, included in that person's personal rights.

The proposed framework would allow living persons or representatives of deceased persons to control, transfer or destroy body parts and would provide remedies for misuse. Representatives would be required to carry out the wishes of the deceased and these wishes could not be overridden by family members.

The legislation would prohibit the sale of organs, although payment of expenses to living donors and a funeral benefit to the estates of deceased donors is recommended. The framework would enable the parties to negotiate the equitable distribution of the profits from the commercialisation of human tissue and, in particular, from the patenting of inventions based on it. Negotiation of benefits could be on an individual basis, if a person had unique properties required for the research, by patient groups, or by the Human Tissue Authority. However, in most cases, the consent process would include the intended arrangements for profit sharing and sources would decide whether or not to participate on that basis. 


\section{Chapter 1}

\section{PROPERTY RIGHTS}

\section{INTRODUCTION}

In common usage, the term "property" relates to material objects, whereas the legal definition of property is the collection of interests a person may have, incident to ownership, and protected by the state. The characteristics of property relating to its use, transfer and enjoyment are known as property interests and the aggregate of these interests connotes ownership. Property owners may be subject to restrictions on the use of their property or may extend ownership by creating ownership interests in other persons, such as by gift. Legal ownership can arise through a variety of interest combinations, including exclusive possession or enjoyment, transferability, alienability and divisibility.

The relationship between persons and their bodies has many of the characteristics of ownership, such as possession, exclusive use, the ability to waste, modify, destroy or alienate, immunity from forced appropriation and the ability to give body parts to others. Courts' decisions as to whether there are property interests in body parts have varied, depending on the public policy objectives and the factual circumstances. ${ }^{1}$ Property is a complex notion that varies in different situations and most normative theories of property initially seem ill-suited to body parts.

The fundamental argument against property interests in human body parts is that if persons are able to exercise control over their own bodies in a way that characterises their having commercial property in their bodies, this results in them treating themselves as means only and not as ends in themselves, consequently violating their human dignity. In contrast, the pro-property position is that to deny people the right to exercise property control over their bodies violates their human dignity, especially if third parties who obtain the body parts are able to have property rights. This thesis argues that once body parts are excised, a property-based framework with reasonable restraints is less offensive than the current situation, whereby the source does not have property rights, but subsequent possessors of the parts do acquire such rights. ${ }^{2}$ It would allow the source to restrict the uses to which the property might be put, and the control and protection provided by property law could prevent the degradation of personhood, by protecting autonomy and giving the source enforceable interests. stating: ${ }^{3}$

Andrew Grubb considers the reasons why human rights alone are inadequate,

\footnotetext{
${ }^{1}$ See the cases in chapters 2 and 3. Historically, the feudal doctrine of tenures and slavery were examples of property rights in the human body. This continued until slavery was abolished in the nineteenth century. See H Catterall Judicial Cases Concerning American Slavery and the Negro (Irish University Press, Shannon, 1968) 13.

${ }^{2}$ Examples of the source's lack of control over body parts include the potential for unconsented use of biobanked material (see chapter 3 ) the patenting of genes (see chapter 7) and the ability for family members to override the deceased's wish to be an organ donor (see chapter 2).

${ }^{3}$ Andrew Grubb “I, Me, Mine': Bodies Parts and Property" (1998) 3 Medical Law International 299317.
} 
English law has developed in the last decade to provide significant protection to individuals' self-determination - by recognising a "right of bodily integrity"such that the taking of any tissue from a competent adult person would be unlawful without the consent of the source. The law is, however, solely concerned with the 'taking' rather than the 'use' of extra-corporeal organs or tissue. By contrast, property law would have something to say about subsequent 'use' and 'control'.

A right to bodily integrity is a right not to be physically harmed against one's will. A right not to have body parts removed without consent derives from a right to bodily integrity in so far as consent is required, because removal amounts to physical harm. Consequently, to assert the source has rights over subsequent uses cannot be attributed to a right to bodily integrity, as no further physical harm ensues.

It might be argued that property rights are not the only rights that may allow control over excised body parts, as a right to prevent certain uses may be claimed to be the exercise of a right to personal integrity. For example, some Māori might object to the use of their genetic material in research involving genetic modification, because of cultural beliefs around whakapapa. ${ }^{4}$ Participants might also object to research that might expose particular groups to discrimination, as with research into Māori and the "warrior gene". 5 A requirement to obtain consent for future uses of excised body parts could be grounded in the need to protect such a personal right. Justification could take one of the following two forms:

- An interest or primary-right specific form, which exists subject to the subsequent use offending the source's personal integrity. Objection would require the source to establish some conscientious objection to prohibit the use; or

- $\quad$ Respect for the personal integrity of the source could be sufficiently important that the source may prohibit future use without pointing to offence to personal dignity, with the only relevant factor being that it is the source's body part.

The second form is preferable, because it avoids the necessity to decide on a schedule of grounds for objection, a proposition that should be rejected because it requires value judgments about personal beliefs. Consequently, in order to assert that the rights of control are based on a property right, rather than some other right, it is necessary to decide what aspect is uniquely a property right.

It will be argued that the entire body falls more naturally within notions of personal rights that safeguard an inviolable corporeal identity. Such an assertion requires justification for the distinction between body parts within the entire body, as contrasted with excised parts, to determine, how a body part that is not property whilst part of the entire body becomes property once it is excised.

\section{A Work and Skill}

\footnotetext{
${ }^{4}$ See chapter 5.

5 Agençe France-Presse "Maori Slam 'Warrior' Gene Study" (9

August 2006) <http://www.abc.net.au/science/news/stories> (last accessed 20 August 2006).
} 
Doodewood $^{6}$ is authority for the proposition that human material can be the subject of property if a body has undergone a process or other application of human skill. If the work and skill is the surgical removal of an organ in transplantable condition, or the collection and preservation of samples, this would point to the property interest being held by the hospital, surgeon or researcher, rather than the source. However, living sources must subject themselves to some discomfort or inconvenience for the harvest of body parts. This equates to work and skill and doctors act as agents for sources when removing the parts. Alternatively, as excised body parts have different attributes, or a use or significance beyond their mere existence, ${ }^{7}$ they are different things from the entire body, so property interests might arguably arise under the Doodewood exception. ${ }^{8}$ Thus, an excised kidney in a dish awaiting transplantation is a different entity and has a use or significance beyond its mere existence, when compared with a kidney forming part of a complex entire living body. $^{9}$

\section{B First Occupancy}

An alternative approach is first occupancy- the argument that property rights arise when an unowned resource is occupied or possessed and the intention made clear that a person claims ownership. Thereafter, others have a duty not to interfere with the first owner's private ownership of the resource. Becker stated that the occupier must show with reasonable clarity how much is being occupied and there must be some limits to occupation. ${ }^{10}$ Waldron argues that this theory satisfactorily resolves disputes about ownership of a resource, but does not explain why private property is preferable to other types of property system, as first occupancy allows individuals to impose duties on everyone else. ${ }^{11}$ Becker argues that it may give a right to possession, but not necessarily a claim-right to keep the thing. ${ }^{12}$

One method of demonstrating a person's ownership of a thing is to show that it was acquired fairly from a person who had title. However, at the beginning of the chain, the issue of original title remains. In terms of this thesis, a body part does not exist as a separate entity until excised from the entire body. First occupancy would suggest that if the part is unowned, it is then able to be claimed by the doctor or hospital that has possession of it. Consequently, the source would have no ability to direct the recipient of an organ or control the research use of body parts. The public policy disadvantages from such an approach were discussed in Colavito. ${ }^{13}$

This thesis proposes legislation providing for a property interest in excised body parts and cadavers. This leads to consideration of a theory under which such

\footnotetext{
${ }^{6}$ Doodeward v Spence (1908) 6 CLR 406, 414 (HCA) Griffith CJ, Barton, Higgins JJ.

${ }^{7} R v$ Kelly [1998] 3 All ER 741, 750.

${ }^{8}$ Doodeward $v$ Spence, above. See the discussion in chapter 2.

${ }^{9} R v$ Kelly, $R v$ Lindsay [1999] Q B 621, 631C (CA) Rose LJ, Ognall, Sullivan JJ. See the discussion in chapter 2 .

${ }^{10}$ Lawrence C Becker Property Rights: Philosophic Foundations (Routledge \& Kegan Paul Ltd, London, 1977) $\mathrm{ch} 3$.

${ }^{11}$ Jeremy Waldron The Right to Private Property (Oxford University Press, New York, 1990) 285.

${ }^{12}$ Becker, above, 28-30.

${ }^{13}$ Colavito $v$ New York Organ Donor Network Inc (2006) 438 F 3d 214; 2006 US app LEXIS 4309

(US App Ct) Sack J. See the discussion later in this chapter.
} 
rights arise. Some theories proposed by commentators are considered in this chapter. This thesis does not aim to develop an original concept of property, nor add to the established body of property law jurisprudence. Rather, it suggests a legislative framework for the collection, retention and utilisation of body parts. ${ }^{14}$ This section attempts to define property right in the sense that is expressed in the framework, rather than considering the broader justifications for private property. ${ }^{15}$

Part I of this chapter outlines the general conceptions of property upon which the thesis is based. Part II considers whether sufficient protection can be achieved through human rights, by way of the principle of respect for individual autonomy, which embodies a view of the individual as an independent moral agent whose choices must be respected. It argues that the conflation of informed consent with autonomy restricts autonomy, while only giving an illusion of power and control to the individual and that personal rights are inadequate to protect sources' interests in controlling body parts after excision and benefiting from their economic value.

\section{PART I}

\section{THE NATURE OF PROPERTY RIGHTS}

This section will consider what it means to assert that there are "property rights" over an object. This involves consideration of the nature of property rights and which objects might be "property". No single definition of private property has produced a universal or general meaning and, apart from the idea that property rights are rights of control over objects, there appears to be little consensus about what constitutes having an object as one's property. ${ }^{16}$ As stated by Bernard Dickens: ${ }^{17}$

To enquire whether a person has property in the in situ or separated materials of his own living body requires a more precise definition of property, possession, ownership, and associated legal concepts than seems to exist.

This thesis argues that a property right is a right to a thing, which is generally enforceable against others. There are two dominant senses in which the word "property" is understood. The first is that property is a physical or tangible thing, which is the reified perspective; the second is that property is a bundle of rights.

\section{A Reified Perspective}

\footnotetext{
${ }^{14}$ See the discussion of the UK Human Tissue Act 2004 in chapter 2, in which it is suggested that legislation does not specify a property interest but, in many respects, treats body parts as though they are property.

${ }^{15}$ As in J W Harris Property and Justice (Clarendon Press, Oxford 1966); S R Munzer A Theory of Property (CUP, Cambridge, 1990); J Waldron The Right To Private Property (Clarendon Press, Oxford, 1988).

${ }^{16}$ Lawrence C Becker Property Rights: Philosophical Foundations (Routledge, London, 1977) 2-4; J Waldron The Right to Private Property (Clarendon Press, Oxford, 1988) 28-30; S R Munzer A Theory of Property (CUP, Cambridge, 1990) 15-36; J W Harris Property and Justice (Clarendon Press, Oxford 1996) 6-8; R A Posner Economic Analysis of Law (5ed, Aspen, New York, 1998) 39; J E Penner The Idea of Property in Law (2ed, Clarendon Press, Oxford, 1997) 1-6.

${ }^{17}$ Bernard Dickens "The Control of Living Body Materials" (1977) 27 U Toronto L J 142, 144.
} 
Most writers in the nineteenth century adopted the reified perspective, as is shown by Strahan, writing in the nineteenth century, who said: ${ }^{18}$

Only things which can be owned are determinate things, that is, an actually existing physical object....We cannot in this sense own a debt, or a patent, or a copyright, all of which are mere creations of the law, without any physical embodiments over which physical power can be exercised. Accordingly, strictly speaking, such rights are not property.

\section{Kant stated: ${ }^{19}$}

Man cannot dispose over himself because he is not a thing; he is not his own property; to say he is would be self-contradictory; for in so far as he is a person he is a subject in whom the ownership of things can be vested, and if he were his own property, he would be a thing over which he could have ownership. But a person cannot be property and so cannot be a thing which can be owned, for it is impossible to be a person and a thing, the proprietor and the property.

\section{Similarly, Strahan stated: ${ }^{20}$}

Physical objects alone, then, are subjects of ownership. But all physical objects cannot be owned. For example, there cannot by English law be any property in a human body, living or dead, though the executors of a dead testator are entitled to possession of his body for the purposes of burial.... With this exception, however, it may be said generally that any material thing of which physical possession can be taken may be owned.

Property was restricted to the tangible, because it was theoretically connected to control and domination over the thing or the ability to alter the original nature of the thing by the expenditure of labour. The concept was that once a person has control or dominion over a thing, or has altered it from its naturally occurring state, then it becomes that person's property. This idea of control and alteration led Locke to opine that every person has a proprietary interest in his or her body. ${ }^{21}$

Locke said that we have a property right in our moral persons, not that we have a property right in our physical bodies. This implies that we have title in that with which we have mixed our labour, because labour is the expression of our agency and status as persons. We only have title to that which we have worked to make, so we do not own our bodies just because we inhabit them. Property is thus linked to self ownership and is derived from the interrelationship between value creating labour, purposeful activity and our agency, from ownership of our entire bodies. However, this thesis argues that the excision of body parts from the whole body requires intentionality and control and involves a variety of procedures, some of which are highly invasive (such as living organ donation). Thus, sources have property in their

\footnotetext{
${ }^{18}$ James Andrew Strahan A General View of the Law of Property (2 ed, Stevens and Sons Ltd, London, 1897).

${ }^{19}$ Immanuel Kant "Lectures on Ethics" in H J Paton (ed) Groundwork of the Metaphysics of Morals (Hutchinson, London, 1953) 165.

${ }^{20}$ Strahan, above, 4.

${ }^{21}$ John Locke The Second Treatise of Government Thomas P Peardon (ed) (The Liberal Arts Press Inc, New York, 1952) 17.
} 
own labour. ${ }^{22}$ The labour of the surgeon who removes the organ is provided as the source's agent and would not result in the doctor having separate property rights.

Commentators have disagreed about whether property is limited to tangible objects $^{23}$ or whether it includes the intangible. ${ }^{24}$ This thesis relates to excised body parts, which are tangible objects, but argues that property rights may include the intangible. $^{25}$

\section{B Bundle of Rights}

Having argued that sources' property in excised body parts can justifiably be regarded as conferring Lockean property rights, the type of right will now be considered. Commentators such as Hohfield ${ }^{26}$ and Honoré ${ }^{27}$ argue that private property consists of in rem rights between people in relation to things, thus liable to be exacted against a thing. The commonly accepted "bundle of rights" theory is derived from a combination of Hohfeld's "framework of legal relations" and Honoré's concept of "full ownership". ${ }^{28}$ Hohfeld contended that there was confusion in the usage of terms such as "right" and "duty." His response was to devise a series of fundamental legal rights and obligations, which were set out as correlatives or opposites. They included rights, duties, privileges, no-rights, powers, liabilities, immunities and disabilities. Correlatives describe the view of the legal relationship from the perspective of each side of the relation. Thus, a right is an affirmative claim against another, which creates a correlative duty in the person on the other side of the legal relationship to act or avoid acting in a certain manner. A privilege is the legal freedom from the claim of another person. The person against whom the privilege exists has a correlative "no right" to determine that the person with the privilege must act or not act according to the privilege.

Modern property rights models build on these concepts to formulate the incidents of ownership. Honoré developed a concept of "full ownership", which consisted of rights, or incidents, of ownership. ${ }^{29}$ These included the right to possess, the right to use, the right to manage, and the power of transmissibility. He argued that all were necessary to have full ownership, but not all incidents were needed to have some form of ownership. His incidents were subject to varying definitions and he allowed for limitations on the scope of these incidents, so, even though a person may have the right to use a parcel of land, that use could be limited by the law. ${ }^{30}$ Honoré

\footnotetext{
${ }^{22}$ Labour in this context would include the pain and suffering involved in the donation.

${ }^{23}$ B Boukhart "What is Property?" (1990) 13 Harv J L \& Pub Pol'y 775, 796.

${ }^{24}$ J W Harris Property and Justice (Clarendon Press, Oxford, 1996).

${ }^{25}$ Chapter 7 considers patenting and accepts that intellectual property rights exist separate from the physical existence of the patented invention.

${ }^{26}$ Wesley Hohfeld "Fundamental Legal Conceptions as Applied in Judicial Reasoning” (1913) 23 Yale Law Journal 16.

${ }^{27}$ Tony Honoré Making Law Bind: Essays Legal and Philosophical (Oxford University Press, Oxford, 1987);

${ }^{28}$ Lawrence C Becker Property Rights: Philosophic Foundations (Routledge and K Paul, London, 1977); J E Penner “The 'Bundle of Rights' Picture of Property” (1996) 43 UCLA L Rev 711; Tony Honoré Making Law Bind: Essays Legal and Philosophical (Oxford University Press, Oxford, 1987); Wesley Hohfeld "Fundamental Legal Conceptions as Applied in Judicial Reasoning" (1913) 23 Yale Law Journal 16.

${ }^{29}$ Becker, above, 19.

${ }^{30}$ Becker, above, 20.
} 
argued that property rights are typically aggregates of different sorts of rights (or liberties) and rights-correlatives, and so a person may have the right to use and may exercise the right, which amount to a privilege. An essential feature was that "none of the characteristics which define the full or liberal notion of ownership in modern legal systems is necessary to all varieties of ownership." ${ }^{31}$ Consequently, there are a wide range of sets of rights which, when held by a person, can justify the claim of ownership. These sets have come to be known as "bundles of rights".

Relativity of title also flows from Hohfield's theory. This is the notion that property rights are neither absolute nor good against the whole world, but rather are relative and limited, circumscribed by the conflicting interests of others. This meaning has the difficulty that it does not indicate what part of a bundle of separable rights, which includes, for instance, rights of possession, control, use, and exchange, is the necessary minimum to constitute property, implying that the word may have no common convention. Honore suggests that ownership in the fullest sense requires all eleven elements, which severely restricts the scope for having property rights.

There are several difficulties that arise when applying these "sticks" to body parts, such as the power to alienate, the right to security and the liability to execution. ${ }^{32}$ Munzer proposes to remove from the "bundle of rights" such incidents as are inappropriate for body parts and classifies body rights into personal rights and weak and strong property rights. ${ }^{33}$ Body parts fit within the description of property under the Hohfeldian framework to the extent that a source has rights, privileges, powers and immunities in relation to others. Each person has the right to possession and use of their body parts free from interference from others, leading to a duty on others to avoid interrupting in that person's use. The person has the right to refuse a request for a body part, even if donation would cause minimal inconvenience, and the other person has no right to demand that a sample be given. ${ }^{34}$ The source has the right to alienate body parts, by giving them to another or by placing them under the control of another. This demonstrates that the legal relation between the source and others with respect to body parts consists of a combination of rights, privileges, powers and immunities, even if it does not amount to "complete property". 35

The Hohfeld-Honoré model has been extended by the addition of accession and specification to resolve problems that are too complex for the model. An accession is something added to existing property. The general rule is that the value of the accession follows the object to which it has attached, so the owner of a chattel owns all things united with that chattel. ${ }^{36}$ If new property is created from the labour of one person and the material of another to transform the material into an entirely

\footnotetext{
${ }^{31}$ Becker, above, 22.

32 Jasper A Bovenberg Property Rights in Blood, Genes and Data (Martinus Nijhoff, Boston, 2006) 132.

${ }^{33}$ S R Munzer A Theory of Property (Cambridge University Press, Cambridge, 1990) 54-55.

${ }^{34}$ As considered in McFall v. Shimp (1978) 10 Pa D \& C 3d 90. However, body parts may be compulsorily acquired in forensic contexts, such as blood alcohol testing.

${ }^{35}$ For example, the source does not retain control of a blood sample given for laboratory testing, but the source can demand that the sample be returned or destroyed after testing. See Health and Disability Commissioner (Code of Health and Disability Services Consumers' Rights) Regulation 1996, Right 7(9).

${ }^{36}$ Erik B Seeney "Moore 10 Years Later- Still Trying to Fill the Gap: Creating a Personal Property Right in Genetic Material" (1998) 32 New England L Rev 1131, 1151.
} 
different species, the owner of the original material has lost the right to the new species. This is known as the doctrine of specification. ${ }^{37}$ If the person who transforms the material is an innocent trespasser, the owner of the original material may recover the value of the materials before their conversion but, if the trespasser was not innocent, the Courts have tended to award the full market value of the converted material to the rightful owner. ${ }^{38}$ Commonly, in research the samples are processed, from storage through to the creation of cell lines. If a sample is cultured it may not be representative of the total specimen used and the longer it is in culture the less it is like the original specimen. Consequently, it becomes difficult to consider the cell line or culture as the "fruits" of the original sample. Under the theory of accession the owner of the material would be entitled to such fruits. However, specification would apply, which would vest full title in the person who added the most value to the final product.

In Moore $v$ Regents of the University of California, ${ }^{39}$ the researcher added value to Moore's cells by inventing a method of reproducing them. The patent was given for the modified biogenetic product, not the cells themselves, so the method could be argued to be an accession. As the value of the accession follows the object to which it is attached, the owner of the object has all those things united with that chattel, thus, if he owned his spleen, Moore would have title to the patent. However, as the material was combined with the labour of another, the theory of specification comes into play. So Moore would only have a claim for the market value of the spleen and would not have a claim to the resultant new species- the cell line. However, as the property was wilfully converted, the labourer should receive no benefit from the labour.

In deciding which rights must be present before private property exists, various theories have arisen.

\section{Natural Rights Theory}

The natural rights theory of property argues that every person has property in his own body and that the person's individuality, created by nature, is innate and cannot be separated from the person. ${ }^{40}$ This conception of property arises from the laws of nature, rather than from the laws of man, since individuality is of natural origin. ${ }^{41}$ Personal identity and individuality are necessary for individual selfrealisation. Property, (which is expressed in terms of ownership), is an extension of the concept of personal identity to relations between persons with respect to objects. ${ }^{42}$

This theory justifies the recognition of a property interest in body parts because they are necessary for an individual's self-realisation and self-identity. ${ }^{43}$ The

\footnotetext{
${ }^{37}$ Seeney, above, 1151.

${ }^{38}$ Seeney, above, $1152-3$.

${ }^{39}$ Moore $v$ Regents of the University of California (1988) 249 Cal Rptr 494, 215 Cal App 3d 709 (App Div) modified (1990) 51 Cal 3d 120, 271 Cal Rptr 146, 793 P 2d 479 cert denied, (1991) 499 US 936. This case is considered in detail in chapter 3 .

${ }^{40}$ Thomas Hodgskin The Natural and Artificial Right of Property Contrasted (B. Steil, London,1832) 18; <http://oll.libertyfund.org > (last accessed 12 June 2006).

${ }^{41}$ Hodgskin, above, 29, 41.

${ }^{42}$ Hodgskin, above, 29. These objects need not be tangible.

${ }^{43}$ Hodgskin, above $28-29$.
} 
physical body is essential for the person's identity, and having been given by nature, it cannot be denied by law. If the right of control over one's body, the right to exclude others from exercising that control, and the right to dispose of the body or parts of it are fundamental rights, then the conclusion must be that natural law theory recognises a property right in the human body. ${ }^{44}$ The natural rights perspective hinges on the individuality of the person, which requires that the person be able to control its expression, through autonomy and self-determination. ${ }^{45}$

Hegel argued that ownership of one's body necessarily precedes ownership of any external things. ${ }^{46}$ However, unlike Locke, he argued that no absolute property rights in the body could exist; rather, sources could decide when and how they wish to relinquish their rights to "the members of [their] bodies." ${ }^{47}$ Hegel took Locke's natural rights theory and added the element of human choice into the calculus of defining property rights.

The right of dominion over one's body, inherent in autonomy and selfdetermination, involves the right to possess, use, and dispose of the elements of the body, subject to certain limitations, such as the duty to avoid actions that harm others. These interests are characteristic of property and are fundamental interests under a natural rights theory. Consequently, informed consent is a subset of property interests under a natural rights framework.

\section{Labour Theory}

The labour theory of property asserts that each person is entitled to the ownership of whatever they acquire or create through their own labour. Locke asserted that each individual has a "property in his own person" and that no one other than that individual has a claim to that property. ${ }^{48}$ The property in one's person is one's individuality, which cannot be separated from the person. Accordingly, Locke asserted that since the labour of one's body is also one's property, then anything mixed with labour necessarily becomes property. Thus, everything of value derives from the individual's body and from the labour of that body.

Becker argues that since labour increases the value of the thing and unappropriated things are "no use", the labourer is entitled to property rights in the thing laboured upon. The conclusion is that one is entitled to the value one's labour adds to the thing, not the thing itself. ${ }^{49}$ An alternate argument is that since things are of no use until appropriated and appropriation usually involves labour that would not

\footnotetext{
${ }^{44}$ Ellen F Paul "Natural Rights and Property Rights" (1990) 13 Harv J L Pub Pol'y 10 (arguing that the appellate majority and dissenting opinions in Moore display the tension between the natural rights and the utilitarian views of property).

${ }^{45}$ As discussed below, the need for individuals to maintain control over their persons and identities has focussed on informed consent.

${ }^{46}$ Georg Wilhelm Friedrich Hegel Philosophy of Right (T M Knox trans) (Oxford University Press, Oxford, 1967) $§ 44$.

${ }^{47}$ Hegel, above, $\S 47$.

48 John Locke The Second Treatise of Government Thomas P Peardon (ed) (The Liberal Arts Press Inc, New York, 1952) para 123.

${ }^{49}$ Lawrence C Becker Property Rights: Philosophic Foundations (Routledge \& Kegan Paul Ltd, London, 1977) 34.
} 
be undertaken except for the anticipated benefits, the labourer should get property rights in the thing laboured upon. ${ }^{50}$

Nozick asked why mixing one's labour with a thing should make the thing the property of the labourer, rather than losing the labour. ${ }^{51}$ If Locke's argument that mixing labour with the property of another does not give the labourer property is accepted, why then should the first labourer obtain rights superior to the common rights held by all ${ }^{52}$ For Mill, property comprised the rights to things that human beings produce by their own labour because those who are excluded have not lost anything if they cannot share in a thing that otherwise would not have existed at all. Thus, no property right in the entire human body could exist, since the body is not a product of human labour, but, as has been argued, body parts are created through the mental and physical endeavours of sources and their agents.

Bodies contain the elements of individual identity and as each person's individuality is that person's property, the embodiment of that identity in their body parts must also be their property. Thus, the labour theory does not justify finding property in body parts as a consequence of an individual's labour, but as a result of the initial theoretical assumption of property in the person. ${ }^{53}$

\section{E Social Utility Theory}

Social utility theory justifies the legal protection of property because property promotes the maximum fulfilment of human happiness. ${ }^{54}$ Society as a whole benefits from encouraging individuals to capture unutilised resources and improve them for more efficient use and, as protection of property interests maximises social welfare, the individual's claim to the created object must be protected against others who assert a claim to it. Utilitarianism counters natural rights theory and argues that property rights exist only because human behaviour and laws create and grant them. Thus, while early natural rights theorists assumed that property rights exist in the human body, utilitarians denied this right.

The two major strands of social utility theory are the traditional utility argument, which defines happiness broadly to include the entire spectrum of human needs and aspirations and the economic argument, which defines happiness as that which can be obtained through market transactions. ${ }^{55}$ The focus of both is on society as a whole, not on the individual, since the goal of each strand is to maximise social welfare. This theory only protects property interests to the extent that they promote overall social welfare, so it is contrary to the natural rights perspective, as social utility theory does not accept the prospect of individual interests trumping the common good. ${ }^{56}$

\section{$1 \quad$ Traditional Utility Theory}

\footnotetext{
${ }^{50}$ Becker, above, 35 .

${ }^{51}$ Robert Nozick Anarchy, State and Utopia (Basil Blackwell, Oxford, 1974) 174-175.

52 Jeremy Waldron The Right to Private Property (Oxford University Press, New York, 1990) 189_ 190.

${ }^{53}$ Robert Nozick Anarchy, State, and Utopia (Basil Blackwell Oxford, 1974) 206 - 207.

${ }^{54}$ Alan Ryan Property (University of Minnesota Press, Minneapolis, 1987) 54.

${ }^{55}$ Lawrence C Becker Property Rights (Routledge \&Keegan Paul, London 1977) 57.

${ }^{56}$ Ryan, above, 53.
} 
This theory assumes that attaining human happiness is desirable and the maximisation of human happiness across society should govern the outcome of all individual and societal choices. ${ }^{57}$ In addition, each incident must individually contribute to societal welfare. ${ }^{58}$

In Moore ${ }^{59}$ George J placed the various "competing interests" on the appropriate sides of the property interest question and concluded that Moore's interests did not promote the common good and that the interests of the public would maximise societal welfare. This analysis has the advantage of flexibility, but that is also a weakness, as it results in uncertain outcomes and may justify either radical change or the status quo. ${ }^{60}$ The utilitarian perspective often determines the outcome of the required balancing and the result depends not on the nature of the property interest, but on its perceived impact on society.

Moore suggests the format of a utilitarian analysis of enforceable property interests in body parts, but not the likely outcome. On the one side, the utilitarian would identify the source's interests in autonomous decision making, control and economic interests. On the other side would be the interests of medical researchers and the interests of society in maintaining public health. The outcome of weighing these interests against each other will depend on the court's view of the consequences of recognising a property interest. Consequently, the traditional utility theory cannot predict the acceptance of property interests in body parts without some knowledge of the perspective of the utilitarian performing the balancing test.

\section{The Economic Utility Theory}

This unpredictability led to the development of a utility theory based on economic concepts. ${ }^{61}$ The economic utility theory justifies the protection of property interests as a means of creating incentives for the efficient use of resources. ${ }^{62}$ Economic utility theory is a variant of the traditional utility theory, in that social welfare is narrowly defined as only that obtainable through market transactions.

This theory assumes that all market participants are rational maximisers of their own economic satisfactions and does not contemplate irrational or inefficient decisions. ${ }^{63}$ The economic utility theory generally ignores justice and other unmeasurable normative principles. Under the economic utility theory, any result is acceptable, irrespective of the motives of the participants or the consequences of the transactions.

The economic utility theory of property would recognise a source's property

\footnotetext{
${ }^{57}$ Becker, above, 59.

${ }^{58}$ Ryan, above, 54.

${ }^{58}$ Becker, above, 61.

${ }^{59}$ Moore v Regents of the University of California (1988) 249 Cal Rptr 494, 537-40 (Cal Ct App)

(George J dissenting) aff'd in part, rev'd in part, (1990) 793 P2d 479 (Cal) cert denied (1991) $111 \mathrm{~S} \mathrm{Ct}$ 1388. See the discussion in chapter 3.

${ }^{60}$ Ryan, above, 115 .

${ }^{61}$ Becker, above 67.

${ }^{62}$ Richard Posner Economic Analysis of Law (Little Brown, Boston, 1973) 10-13.

${ }^{63}$ Becker, above, 70.
} 
interest in body parts, if the parts have an inherent value in the marketplace. Clearly, body parts have value to researchers, recipients and sources. Under the economic utility theory, any valuable object will be more efficiently distributed through a series of voluntary market transactions than through other allocation systems. Thus, body parts should be exchangeable through the free market.

Since they will be available to market participants, they must be owned initially by someone. The original owner should be the individual whose body is the source of the parts and so has possession of them and is able to control their transfer to others. The source's property interests must be transferable, to allow the source to make the most efficient productive use of the resource. ${ }^{64}$ Therefore, if body parts are a valuable resource, the property interests should be protected in order to create economic incentives for market participants to use the resources efficiently. Restraints on alienation would resolve the problem of unauthorised use. ${ }^{65}$

\section{F Application of Theories of Property Justification}

The following section will consider how some commentators have applied property theory to body parts, to demonstrate the complexity of this issue. For example, Narveson argues that to be free to do something means to be free to use what one owns and, because he argues further that all rights are freedom rights, it is plausible to argue that all rights are property rights. ${ }^{66}$ Clearly, if such a broad definition of property is adopted, it will be easier to justify an item as property than if a definition is used such as that proposed by Honoré.

\section{$1 \quad$ Gaus}

Gaus suggests a "core" definition of property would be that for a person to have unimpaired ownership rights over something that person must have at least the following rights:

- $\quad$ Right of use;

- Right of exclusion;

- $\quad$ Right of transfer;

- Right to compensation. ${ }^{67}$

He argues that when liberal theorists claim that people own their bodies, their claim is "attenuated" unless these four conditions apply to their relations to their bodies. This is because they apply to those things that liberals most characteristically claim to be property. He states that the right of transfer distinguishes property rights from rights to bodily integrity and the claim that persons own their bodies is controversial because it is not generally accepted that persons may permanently transfer rights over their own bodies to others. However, that argument is less convincing when considering extracorporeal body parts, as these are commonly transferred to others, for example, in living organ donation.

\footnotetext{
${ }^{64}$ Posner, above, $10-13$.

${ }^{65}$ Alienability is an incident of property ownership, by transfer, gift, devise or abandonment.

${ }^{66}$ Jan Narveson The Libertarian Idea (Temple University Press, Philadelphia, 1988) 66.

${ }^{67}$ Gerald F Gaus "Property, Rights and Freedom" in Ellen Frankel Paul, Fred D Miller Jr and Jeffrey Paul (eds) Property Rights (Cambridge University Press, Cambridge, 1994) 213-214.
} 
In contrast to the approach that attempts to identify an essence of property as a set of necessary and sufficient conditions for something to be property, other commentators, such as Thompson, argue that "ownership is really no more than a cluster of claims, privileges and powers." 68 If a person has rights over a thing that sufficiently resemble rights that people have over things commonly recognised as property, then there is no harm in considering those rights to be property rights. This view leads to the concept of property as a shifting bundle of rights, because not everything that someone will consider to be sufficiently like core instances of property will have the same characteristics and there may be variations in the notion of core instances.

Munzer argues that there are three main principles for justifying property. ${ }^{69}$ These are a principle of utility and efficiency, a principle of justice and equality, and a principle of desert, based on labour. The theory is pluralist in the sense that the principles are irreducible and sometimes conflict. He states that when conflicts occur, priority rules can resolve most, but not all, conflicts. The principle of utility and efficiency requires that property rights should be allocated so as to maximise utility and efficiency. The principle of justice and equality provides that unequal property holdings are justifiable if:

- $\quad$ Everyone has a minimum amount of property; and

- The inequalities do not undermine a fully human life in society.

He argues that this principle is a standard of justice, as it morally regulates the sharing of benefits and burdens among persons and also a standard of equality as, if persons have different property holdings, it must be shown why the difference is morally and politically acceptable. The theory includes a principle of desert or entitlement, which rests on a conception of persons as agents who, by their actions in the world, are responsible for changes in it and so deserve or are entitled to a fitting recompense or response. Whereas the first two principles emphasise, in different ways, the equal worth of persons, this final principle focuses on differences in merit.

The labour-desert principle maintains that a person's work gives a qualified justification for private property rights. This justification of property rights for the labourer is qualified by the rights of others, limitations on the process of acquisition, post-acquisition changes in situation, restrictions on transfer, general scarcity, and the nature of work as a social activity. The principle of justice and equality involves the idea that persons have rights not to have certain of their interests traded for overall utility. This principle therefore differs from the idea, latent in the principle of utility and efficiency, that equal moral worth is just counting persons equally. Equal counting is compatible with sacrificing the individual utility of some to promote overall utility, and any such sacrifice ignores or undervalues the separateness of persons. Munzer argues that as body parts are potentially a highly valuable medical

\footnotetext{
${ }_{68}^{68}$ Judith Jarvis Thompson The Realm of Rights (Cambridge University Press, Cambridge, 1990) 225.

${ }^{69}$ Stephen R Munzer "The Special Case of Property Rights in Umbilical Cord Blood for

Transplantation" (1999) 51 Rutgers L Rev 493, 497.
} 
resource, they should not be allowed to go to waste. One way to prevent such wastage is to establish and protect property rights in them. ${ }^{70}$

\section{$3 \quad$ Reed}

It is possible to define property as a negative right, the right of exclusion as applied to limited resources. Reed argues that property is the constitutional and legal right to exclude others from specifiable limited resources originally possessed or acquired without coercion, deception, or theft. ${ }^{71}$ According to his definition, property has several characteristics. They are that it is:

- a constitutional right;

- $\quad$ recognised and enforced by the laws of the state;

- a right that excludes others from specifiable limited resources; and

- $\quad$ originally possessed or acquired without coercion, theft, or deception.

If it is accepted that property interests protect the resources that are "appropriately" exclusive to an individual, which are those that are originally possessed or acquired without coercing, stealing from or deceiving others, then the relationship indicated by property is one not only between individuals, but also between the individual and the state. Although property in particular resources depends upon values prior to law and arises out of informal ways of ordering, there would be no need for the state to enforce property if people always respected the resources held by others. In this sense property establishes and preserves social order and encourages resource development, by protecting private resources acquired without coercion, theft, or deception from the predations of others in the general community.

Reed stated that: "at the very heart of property lies its singular conceptual core, which is the private right of exclusion." 72 This means that the owner can exclude others from the resource owned and that others have a duty not to infringe this right. Thus, the positive "bundle" of rights like possession, use and alienation can all be derived from the negative exclusionary right. For example, if owners can legally exclude others from interfering with the resources of their land, they can possess the land, use it in a myriad of ways that leave an equal right in others to use their resources, or transfer it through sale, lease, or gift to others.

He argues that people who argue against the "commodification" of certain resources, such as objecting to the selling and buying of particular aspects of the body, are not rejecting the definition of property, only property's application to specific resources. According to these views, property still exists in body parts and human services in the sense that the owner can partially exclude others from them, but the property right has been weakened, in that the owners of these resources are no longer able to exclude others from interfering with the exchange of these resources in the private market. Thus, the objections to property in the exchange of these resources are moral, rather than definitional.

\footnotetext{
${ }^{70}$ Munzer, above, 568.

${ }^{71}$ O Lee Reed "What is 'Property'?” (2004) 41 Am Bus LJ 459, 473.

${ }^{72}$ Reed, above, 487.
} 
From this he argued that individuals own themselves, such self ownership being acquired through original possession and constituting the central organising principle behind most human rights. Reed argues: "From the beginning, individuals own their faculties and the expressions of these resources in all activities of life that do not harm others.", 73

However, Mossoff disagrees with the exclusion thesis. He maintains that exclusion is merely "the formal means by which Anglo-American legal rules identify and protect the substantive core of rights that constitute property", which he identifies as "the rights of acquisition, use, and disposal." 74

\section{$4 \quad$ Gold}

Gold states that property rights are rights that members of society have against each other, and when property rights are granted, this is on the basis of one or more ways of valuing the object or the individual to whom the rights are granted. ${ }^{75} \mathrm{He}$ states that property discourse is based on the assumption that things that are property are best allocated through the market. As property is premised on encouraging economic value, it is not possible to translate other non-economic values into a money price and thus allocate rights of control of body parts through a ranking of these translated money prices. ${ }^{76}$ The status quo, whereby researchers are able to obtain patent rights in human tissues while the sources receive no compensation is unacceptable, so he proposes a comprehensive statutory scheme to regulate the rights and duties of the various participants, which would incorporate economic and noneconomic values. Such a scheme would exclude the application of property law, including patent law, to human biological materials. ${ }^{77}$

Gold does not explain how such a scheme would operate in practical terms. In most cases, it is not the biological materials that are patented, but some development from them (such as a cell line), or some invention (such as a genetic test or treatment). ${ }^{78}$ The biomedical industry is premised on free market principles, thus, implementation of Gold's proposal favouring the creation of a non-profit, nongovernmental organisation to control valuable tissue would be difficult to implement and would have to be globally adopted. ${ }^{79}$

\section{$5 \quad$ Radin}

\footnotetext{
${ }^{73}$ Reed, above, 499.

${ }^{74}$ Adam Mossoff "What is Property? Putting the Pieces Back Together" (2003) 45 Ariz L Rev 371, 396.

${ }^{75}$ E Richard Gold Body Parts: Property Rights and the Ownership of Human Biological Materials (Georgetown University Press, Washington DC, 1996) 3.

${ }^{76}$ Gold, above, 17.

${ }^{77}$ Gold, above, 177.

${ }^{78}$ John Moore's spleen was not patented. The patent related to a cell line derived from the cells from his spleen. See the discussion in chapters 3 and 7.

${ }^{79}$ E Richard Gold "Owning Our Bodies: An Examination of Property Law and Biotechnology" (1995) 32 San Diego L Rev 1167, 1242-46.
} 
Radin argues a personhood analysis of property, based on Hegel's Philosophy of Right. ${ }^{80}$ Hegel viewed property as "the embodiment of personality", the means by which people express their wills in the world. ${ }^{81}$ Radin argues that property is protected, not as a means of expressing personality, but because it is part of a person's identity and personality. ${ }^{82}$ Those aspects, attributes, and qualities of the human person that are so qualitatively vital to the concept of human identity as to be quintessentially "human" should never receive property status.

Crucial to Radin's thesis is the notion of separability: "[ $t$ to conceive of something personal as fungible assumes that the person and the attribute, right, or thing, are separate." 83 She contends that the law should recognise property rights in things to which the person is connected. The strength of the connection is assessed by the effect of loss of the object. Property is on a continuum between personal and fungible, reflecting varying levels of connection between person and object.

Although Radin did not directly address the issue of whether the human body is property under this "personhood" paradigm, she appreciated that all body parts could be esteemed as so "integral to the [human] self that they are essentially distinct from vulgar, fungible market commodities." ${ }^{\prime 4}$ To view a human organ, which likely would be deemed as truly personal to human self and identity, as "monetizable or completely detachable from the person ... . is to do violence to our deepest understanding of what it is to be human." 85 To separate the human person from the body, risks viewing all other people as objects, able to be owned as personal property.

She further developed the concept of separability within the context of alienability. Following Hegel, she defined alienation as "the separation of something ... from its holder." ${ }^{86}$ Applying that model to the human person, she argued that only those things inherently separate from the human self can be alienated from it. ${ }^{87}$

Radin argued that certain things are market-inalienable, meaning that they can never be transferred by contract for sale in exchange for valuable consideration, ${ }^{88}$ although non-saleability does not prohibit donative transfers. ${ }^{89}$ If the human body is treated as an article of commerce, it would eventually lead to the human body itself being thought of as a fungible commodity. ${ }^{90}$ "By making something nonsalable we proclaim that it should not be conceived of or treated as a commodity." 91 Thus, no rights, attributes or things intrinsically unique to the human

\footnotetext{
${ }^{80}$ Georg Wilhelm Friedrich Hegel Philosophy of Right (T M Knox trans) (Oxford University Press, Oxford, 1967).

${ }^{81}$ G Hegel, above, 44.

${ }^{82}$ Margaret Radin "Property and Personhood" (1982) 34 Stan L Rev 957, 986.

${ }^{83}$ Margaret Radin "Market-Inalienability" (1987) 100 Harv L Rev 1849, 1907.

${ }^{84}$ Radin, above, 1907.

${ }^{85}$ Radin, above, 1907.

${ }^{86}$ Radin, above, 1852.

${ }^{87}$ Radin, above, 1852.

${ }^{88}$ Radin, above, 1850.

${ }^{89}$ Radin, above, 1854-1855.

${ }^{90}$ Radin, above, 1907.

${ }^{91}$ Radin, above, 1855.
} 
person should be commodified..$^{92}$ Non-commodification of the human body can be achieved by deeming it and its composite parts market-inalienable.

Radin states: "If the body is property, then objectively it is property for personhood." 93 Thus, it is entitled to the highest entitlement under the law. She considers the existence or not of a property right in body parts is a paradox. They might become fungible commodities, but "on the other hand bodily parts may be too "personal" to be property at all." 94 In this context she refers to the parts prior to excision from the entire body. She suggests: ${ }^{95}$

We have an intuition that property necessarily refers to something in the outside world, separate from oneself....This intuition makes it seem appropriate to call parts of the body property only after they have been removed from the system.

The conclusion from her personhood analysis seems inevitably to be that it is reasonable and necessary to allow sources' property rights in excised body parts, because our bodies are integral to our identity and sense of being. Such property rights are closely connected with personhood and should be protected from interference by others.

\section{$6 \quad$ Beyleveld and Brownsword}

Beyleveld and Brownsword argue: ${ }^{96}$

We suggest that a right to exclusive use of an object is necessary and sufficient to characterize property rights substantively, and that the essential function of a justification on the basis of a property right is to justify a right to exclusive use in a characteristic way.

They argue that, rather than a bundle of rights approach, the general conception of property with regard to body parts is that persons own their bodies according to a "rule-preclusionary" conception of property. ${ }^{97}$ The claim that a person owns an object is a claim that the person has the right to use the object in any legitimate way and to exclude others from using it, because the person stands in a relation to the item that precludes that person having to account on a case-by-case basis for the rights to use it and to exclude others from using it. Thus, property rights are prima facie rights and, if there are reasons that another may use the item that outweigh the person's interest, then the person will not be permitted to control the use of the item. This does not mean that the item is not the person's property- just that the property right is overridden.

Confiscation, which removes the property right, must be distinguished from legitimate removal of control from the property owner, which does not remove the property right. This would be the case if there was a prohibition of the right to

\footnotetext{
${ }^{92}$ Radin, above, 1907.

${ }^{93}$ Margaret Radin "Property and Personhood" (1982) 34 Stan L Rev 957, 966.

${ }^{94}$ Radin, above, 966.

${ }^{95}$ Radin, above, 966.

${ }^{96}$ Deryck Beyleveld and Roger Brownsword Human Dignity in Bioethics and Biolaw (Oxford University Press, Oxford, 2001) 177 (emphasis in original).

${ }^{97}$ Beyleveld and Brownsword, above, 172.
} 
exercise the property right, which is justified on the basis that, in the circumstances, such exercise would conflict with the more important rights of others. Essentially, this is asserting that if property rights over body parts do not exist, there will, as a general rule, not be adequate protection for specific rights.

They argue that if the living body and attached body parts cannot be the source's property, then nothing else can be. ${ }^{98}$ From this they deduce that it does not follow automatically that excised body parts are the source's property, because it does not follow that anything else can be the person's property. To justify that anything else can be property, it must be established that other things stand in the same relation to the source as the living body. They assert that excised body parts have a varying level of importance for the self-agency of the source, yet those differences do not affect the conclusion that sources should be granted a degree of rule-preclusionary control over them, proportional to the degree of seriousness of the claims of others required to override the control of the source. rights:

They support the views of Gewirth, who provides two arguments for property

- A consequentialist argument that such rights protect both the well-being and the freedom that are needed for purposive action and generally successful action. ${ }^{99}$ A person can claim as private property those things over which it is necessary to have control, in order to protect that person's generic rights. However, this construct does not distinguish between the amounts of property that different persons should have or determine whether work in producing items should place the producer in a privileged position.

- An antecedentalist argument deals with these issues by referring to circumstances prior to distribution, suggesting that property rights belong to the persons who produced the objects, in order to prevent exploitation and to protect generic rights. ${ }^{100}$

Gewirth's approach results in body parts attached to the person being property, because to deprive the source of them affects generically the person's capacity to act (or act successfully) and so, deprivation without agreement violates the person's generic rights. Thus the person should have autonomous control unless the use violates the rights of others, or violates human dignity.

Beyleveld and Brownsword argue that to grant the source rule-preclusionary control over body parts best protects the source. It is necessary to avoid the undesirable situation where others would have a right to use the body parts if that use was not specifically harmful to the source, and the source would have to justify any objection. ${ }^{101}$ They argue that the body is vital to personal interests and subject to personal cultural or emotional significances. ${ }^{102}$ Rule-preclusionary control should also be granted to excised parts and body parts after death. Although use of the

\footnotetext{
${ }^{98}$ Beyleveld and Brownsword, above, 182.

${ }^{99}$ Alan Gewirth The Community of Rights (University of Chicago Press, Chicago, 1996, 171.

${ }^{100}$ Gewirth, above, 182.

${ }^{101}$ Beyleveld and Brownsword, above, 187-188.

${ }^{102}$ Beyleveld and Brownsword, above, 188.
} 
corpse cannot be to the detriment of the bodily integrity of the deceased, various uses may offend the personal integrity of living persons, so persons must be able to dictate legitimate uses of their body parts after removal, or death. The benefits of generic rights may be waived, but the generic rights themselves may not be, so a person cannot surrender the right to exclusive use of their body while alive. ${ }^{103}$ Thus, consent should be required both for removal of body parts and their subsequent use, even if there is no known specific promotion of, or threat to, the source's interests. ${ }^{104}$

\section{G Property in Intact Bodies}

Property rights and human persons first arose in the context of slavery, whereby slaves were considered to be chattels and not legal persons. ${ }^{105}$ Subsequent to Sommersett's Case, ${ }^{106}$ it was held that habeas corpus meant that a slave being stored in England should be set free. Consequently, a living person could not be considered property.

Ruth Chadwick states, with respect to intact human bodies: ${ }^{107}$

[A]lthough there is a sense in which persons do own their bodies, this is not the same as the sense in which they own tables and chairs. There is so great a difference between our bodies and other material objects that it is just a mistake to apply the institution of property, with what that is normally taken to imply for rights of transfer and sale, to the body. For my body is not simply 'mine': it is in some sense 'me'.

The issue of property rights or ownership of the body, prior to any severance of body parts from the living body, is of little practical significance, other than as an addition to existing personal rights. ${ }^{108}$ A person's intact body forms part of that person's personal interests, which are principally protected through rights of selfdetermination and respect.

The Law Reform Commission of Canada questioned: ${ }^{109}$

Why, then, should bodies not be regarded as ordinary property? An important answer may be that notions of bodily property do violence to our concepts of personal autonomy and human dignity. Property is traditionally associated with things, not with the human body. To equate the body with a thing is to dehumanise human existence; in the extreme, it suggests the repulsive notion that human beings may be owned. This answer hinges in a thing-person dualism, and an inference that human body parts are reflective of our notion of self.

\footnotetext{
${ }^{103}$ Beyleveld and Brownsword, above, 189-190.

${ }^{104}$ However, that is not necessarily the case as Right 7(10) of the Health and Disability

Commissioner's Code permits unconsented use with ethics committee approval. See the discussion in chapter 3.

${ }^{105}$ Such as in Roman law where slaves could be bought and sold. R Campbell (ed) J Austin Austin's Lectures on Jurisprudence or the Philosophy of Positive Law (5ed) (Murray, London, 1885) vol 1, 387. ${ }^{106}$ Sommersett's Case (1172) Loft 1; 98 ER 499.

${ }^{107}$ Ruth F Chadwick "Corpses, Recycling and Therapeutic Purposes" in Robert Lee and Derek Morgan (eds) Death Rites Law and Ethics at the End of Life (Routledge, New York, 1996) 61.

${ }^{108}$ John Harris "Who Owns My Body?" (1996) 16 Oxford J Legal Studies 55, 66.

${ }^{109}$ Law Reform Commission of Canada Procurement and Transfer of Human Tissues and Organs Working Paper 66 (Ministry of Supply and Services, Ottawa, 1992) 57.
} 
This thesis does not argue that the entire living body is property, but argues that this does not necessarily imply that excised parts of it may not be property. As Grubb argues: ${ }^{110}$

\begin{abstract}
Not only does no one else own my body, neither do I. Legal conceptions of "property" do not extend to ownership of another or self-ownership. This is not to say a person cannot assert property interests in parts or tissue that were part of his body or that property interests cannot be claimed over a dead body or its parts.
\end{abstract}

\title{
H Property in Body Parts
}

This thesis is based on the notion that property rights are only contingently connected to persons and are not intrinsic aspects of them. ${ }^{111}$ Thus, for an object to be the subject matter of property, a human subject must be separate from it. Consequently, body parts are theoretically capable of being characterised as things, because once excised they can be considered to be contingent material possessions. ${ }^{112}$

The argument for treating excised body parts as property is particularly convincing when human sources are alive and have interests in their excised body parts. It would allow individuals to bring claims to protect their interests in stolen or misappropriated body parts, as theft is generally only possible if someone has property in the item taken. ${ }^{113}$

In some jurisdictions, renewable body parts can be the subject of ownership. Blood is commonly sold in America ${ }^{114}$ and is deemed to be full-fledged property - a "product" whose sale constituted "income" under the tax code, while the "business expenses" incurred by the seller in creating this "product" are deductible for the purposes of tax. ${ }^{115}$ There has been recognition of property in hair, urine and bone marrow. In New Zealand, the sale of blood and blood products is prohibited, ${ }^{116}$ as is the sale of gametes and embryos. ${ }^{117}$

\footnotetext{
${ }^{110}$ A Grubb “'I, Me, Mine’: Bodies Parts and Property” (1998) 2 Med L Intl 299.

111 J E Penner The Idea of Property in Law (2 ed, Clarendon Press, Oxford, 1997) 111.

112 Penner, above, 122.

113 Crimes Act 1961, s 217. However, the Human Tissue Act 1964 creates a regime whereby certain classes of person may have a special right of possession to a human corpse. If the corpse or body parts were removed for purposes other than those specified in the Act, this might be held to be a taking from a person with a special property in the body and so be theft within section 220 of the Crimes Act 1961 . This section requires the intent "[t]o deprive the owner, or any person having any special property or interest therein, permanently of such thing or such property or interest."

${ }^{114}$ Blood has become one of the most valuable commodities in the United States. While refined petroleum sells for around US\$40 per barrel an equivalent quantity of blood products is worth US\$67,000. Richard Bernstein “A Science and a Business, a Saver and a Killer” review of Douglas Starr Blood: An Epoch History of Medicine and Commerce (23 September 1998) New York Times New York E7.

${ }^{115}$ P Matthews "Whose Body? People as Property" (1983) 36 CLP 193.

${ }^{116}$ Health Amendment Act 1998, which inserted Part 3A into the principal Act to deal with trading in human blood and controlled human substances.

${ }^{117}$ Human Assisted Reproductive Technology Act 2004, s 13. A similar provision is anticipated in the New Zealand Human Tissue legislation which is to be enacted in 2006 or 2007. See the discussion in chapter 2 .
} 
In Colavito $v$ New York Organ Donor Network Inc, ${ }^{118}$ the plaintiff was the intended recipient of a kidney, which had been implanted into another. He sued the state organ donor network for fraud, conversion and violations of the New York Public Health Law. Sack J held that: "there is by no means a modern consensus that body parts are excluded from conversion actions at common law." ${ }^{119} \mathrm{He}$ added that even if public policy prohibited the sale of organs, this: ${ }^{120}$

.....does not necessarily imply that it also intends that no one can acquire a property right in them. It does not follow from a law that forbids the sale of a functioning human kidney, that a third party may with impunity take the organ against the express wishes of a potential donor and potential donee.

This thesis suggests a legislative framework that would allow the sources of extracorporeal body parts to have property rights, as a basis for handling evolving issues regarding retention, use and control. At the point of transplantation into a recipient, property rights would cease to exist in either the human source or any other person and, as the organ becomes part of the recipient, it is included in that person's personal rights. Thus, if a living donor's kidney was transplanted into the incorrect recipient, the donor would be unable to recover the kidney, but would still have an action against the hospital or medical professional at fault. ${ }^{121}$

\section{PART II}

Although the common law has been reluctant to recognise property rights in body parts, it has for many years provided legal protection to protect invasions of the human body. This section will consider human rights, particularly the right to bodily integrity, which is grounded in notions of autonomy and human dignity, to determine whether the protections of that right are sufficient to enable the source to control the collection, retention, use and commercialisation of body parts.

\section{AUTONOMY}

The right to bodily integrity derives from the concept of autonomy, which is generally expressed as the capacity of individuals to act independently. Autonomy is also linked to the concept of human dignity. ${ }^{122}$ The recognition of human dignity as a fundamental right is expressed in a number of international instruments. ${ }^{123}$ It is an imprecise concept that has not been developed greatly in English law, ${ }^{124}$ but this thesis considers autonomy as an aspect of the broader concept of human dignity. ${ }^{125}$

\footnotetext{
118 Colavito v New York Organ Donor Network Inc (2006) 438 F 3d 214; 2006 US app LEXIS 4309 (US App Ct) Sack J.

${ }_{119}$ Colavito $v$ New York Organ Donor Network Inc, above, 28.

${ }^{120}$ Colavito v New York Organ Donor Network Inc, above, 32-33.

${ }^{121}$ Such action might arise in negligence. Although beyond the scope of this thesis, difficulties could arise in assessing the quantum of damages. However, in jurisdictions where claims arise for personal injury, such assessment is common.

${ }_{122}$ Rees v Darlington Memorial Hospital NHS Trust [2004] 1 AC 309 (HL) 349, Lord Millett.

${ }^{123}$ Preamble to the Charter of the United Nations signed June 261945 USTS 993; Universal

Declaration of Human Rights adopted 10 December 1948 UNGA Res 217 A (III); UNESCO Universal Draft Declaration on Bioethics and Human Rights Paris 24 June 2005 SHS/EST/05/CONF.204/3 REV.

${ }^{124}$ D Feldman "Human dignity as a Legal Value-Part I" [1999] Public Law 682, 682.

${ }^{125}$ McFarlane v Tayside Health Board [2000] 2 AC 59 (HL) 114, Lord Millett.
} 
Autonomy is often conflated with self-ownership. However self-ownership is a proprietary concept, whereas autonomy is not.

The law protects a person's right to act independently by way of the doctrine of informed consent. Although some commentators argue that this is sufficient protection of human rights, it will be argued that informed consent alone is not sufficiently powerful to ensure the protection of the rights of human sources.

Consent is based on the idea that it is not the proper role of the State to interfere in what is done (or not done) consensually to a person, especially if there is no harm to others, because an individual is an autonomous being. In certain circumstances, the State has a role to intervene to protect and promote superior moral interests, but, if no public interest exists condemning the particular action, the primary ethical issue has come to be seen to be whether the competent human source of biological materials has given informed consent.

Thus, autonomy has come to be equated with informed consent. However, this assumption is misleading as, in most cases, consent amounts to either a "yes" or "no" decision, whereas an autonomous decision may be much more complex and involve conditions or limitations. The modern developments in medical research and the potential benefits from utilisation of samples held in biobanks suggest that informed consent alone may be insufficient to determine the resulting complex ethical issues. $^{126}$

\section{A Principlism}

The development of medical ethics had four overlapping periods. ${ }^{127}$ The first was a long period in which the Hippocratic tradition was accepted, having been enriched over centuries by contact with the Stoics and with religious traditions. This period continued until the mid-twentieth century. The second period, beginning in the mid-1960s, was marked by philosophical inquiry and principle-based moral theories began to vary the Hippocratic ethic. In the mid-1960s there was a general upheaval in moral values as a result of a series of societal changes.

The third period, in the late twentieth century, was one of challenge to the ideas of principlism, with competing moral theories challenging the primacy of principles. The fourth period, still continuing, is one in which conceptual conflicts in ethics and the scepticism of moral philosophy challenge the very idea of a universal, normative ethic for medicine.

The theory of prima facie principles, developed by Ross, became the dominant approach to ethics. ${ }^{128}$ Ross listed several moral principles and stated that, if the principles were in conflict, the greatest duty must be found by balancing right and wrong in that particular context. He distinguished between prima facie duties and

\footnotetext{
${ }^{126}$ See the discussion of informed consent below. See also: Ministry of Health Guidelines on the Use of Human Tissue for Future Unspecified Research Purposes Discussion Document (Ministry of Health, Wellington, 2006).

${ }^{127}$ Edmund D Pellegrino "The Metamorphosis of Medical Ethics: A 30-year Retrospective" (1993) 269 JAMA 1158.

${ }^{128}$ William David Ross The Right and the Good (Hackett Publishing Co Inc, Indiana, 1988) 19.
} 
actual duties. A prima facie duty is one always to be acted upon unless it conflicts on a particular occasion with an equal or stronger duty. It is always right and binding, all other things being equal. An actual duty is determined by balancing the respective weights of the competing prima facie duties.

This approach was adapted to medical ethics by Beauchamp and Childress. ${ }^{129}$ They recognised the difficulties of attaining agreement on the most fundamental questions of ethics, such as the nature of the good, the ultimate sources of morality, and the epistemological status of moral knowledge. To bypass these problems, they followed Ross and turned to principles that, on face value, should always be respected, unless some strong countervailing reason exists to justify overruling them. In this prima facie category, they choose principles especially appropriate for medical ethics- autonomy, nonmaleficence, beneficence and justice.

\section{B Criticisms of Principlism}

Principlism lacks explicit decision rules for when the principles conflict, but it does have the advantage that the principles can be accepted by health professionals and be compatible with their underlying, or overarching, moral, religious, political or philosophical theories. Adapting the principles to a particular theory of health-care ethics requires culture-specific interpretation, specification and harmonisation when the principles conflict.

Criticisms of the four principles include that principles are too abstract, too rationalistic, and too removed from the psychological milieu in which moral choices are actually made. Additionally, they ignore a person's character, life story, cultural background and gender. They imply a technical perfection in moral decisions that is frustrated by the psychological uniqueness of each person or action. Commentators have suggested various remedies to replace, complement, or supplement prima facie principles. These include Engelhardt, who places autonomy in the first order of priority, ahead of beneficence, ${ }^{130}$ and Pellegrino and Thomasma, who favour beneficence-in-trust. ${ }^{131}$ Additional alternatives or supplements to principle-based theories include an ethic based in virtue, caring, "experience," or a return to theological and biblical sources as the only reliable grounding for medical morals.

Conventional ethical frameworks, such as principlism, seem inadequate to meet the normative challenges posed by human tissue collections. Informed consent has limitations when material is retained for future unspecified research purposes. ${ }^{132}$ The fact that an individual has given consent does not give that person any control; rather, it assigns control to others.

\section{PROPERTY INTERESTS}

\footnotetext{
${ }^{129}$ T L Beauchamp, J F Childress Principles of Biomedical Ethics (2ed, Oxford University Press, New York, 1983).

${ }^{130}$ H T Engelhardt The Foundations of Bioethics (Oxford University Press, New York, 1986); H T

Engelhardt and M A Rie "Morality for the Medical-Industrial Complex: A Code of Ethics for the Mass Marketing of Health Care"(1988) 319 N Engl J Med 1086.

${ }^{131}$ Edmund D Pellegrino and David C Thomasma For the Patient's Good: The Restoration of

Beneficence in Health Care (Oxford University Press, New York, 1988).

${ }^{132}$ See the discussion in chapter 8 .
} 
Commentators have argued for and against the recognition of property interests in body parts. In this section, common argument are explored and discussed as an introduction to the arguments that will be further explored throughout the thesis.

\section{A Policy Arguments}

This thesis argues that the concepts of informed consent and breach of fiduciary duty relied on in Moore ${ }^{133}$ are insufficient, because they are limited to the doctor-patient relationship. In Moore ${ }^{134}$ Mosk $\mathrm{J}$ argued that the law should, at least, recognise: ${ }^{135}$

...[Moore's] right to do with his own tissue whatever the defendants did with it: i.e., he could have contracted with researchers and pharmaceutical companies to develop and exploit the vast commercial potential of his tissue and its products.

This reflects a view that the persons contributing biological materials should share in the rewards resulting from their contributions. ${ }^{136}$

An advantage of property rights is that they can be asserted not only against the original recipient of the material, but also against any subsequent users who did not have a relationship with the source by way of contract or informed consent. Privacy, informed consent or fiduciary interests would be likely to result in low rates of compensatory or punitive damages, which would be insufficient to deter misuse, whereas property rights would provide for remedies such as an action for the return or destruction of the samples, injunctive relief or damages. Gitter argues that without a property interest "research participants will be left without a remedy, because the harm they suffered affected not their medical interests but rather their dignity and autonomy." 137

A further policy argument relates to equity and justice, in that the sources' role in research is indispensable and it is only fair that they should share in the profits to some extent- just as suppliers of other materials are normally paid.

A contrary argument is that individuals should not profit from their natural endowments, such as Moore's valuable spleen, but only from the benefits resulting from voluntary choices. However, as people are able to freely exploit their beauty, athletic ability, or intelligence, such an argument does not justify denying benefits to contributors of tissue samples for research.

\footnotetext{
${ }^{133}$ Moore $v$ Regents of the University of California (1990) 793 P 2d 479 (Sup Ct Cal). See the discussion in chapter 3.

${ }^{134}$ Moore $v$ Regents of the University of California (1990) 793 P 2d 479 (Sup Ct Cal).

${ }^{135}$ Moore $v$ Regents of the University of California, above, 510 Mosk J.

${ }^{136}$ This argument suggests a property interest which is subject to the contract. See the discussion of PXE International in chapter 3.

${ }^{137}$ D M Gitter "Ownership of Human Tissue: A Proposal for Federal Recognition of Human Research Participants’ Rights in their Biological Material” (2004) 61 Wash \& Lee L Rev 296.
} 
Researchers contribute labour and inventiveness, which are argued to be more deserving of reward than mere contributions. ${ }^{138}$ However, this thesis argues that all participants should be involved in decisions affecting ownership, access to and use of commercialised products and services. Merz argues that this is best achieved by negotiated arrangements with patient groups and that, in the case of individual participants, researchers and institutional review boards should compensate individuals, as a matter of equity. They argue that this is achievable without a need for property or other rights, but just because "it is the right thing to do." ${ }^{139}$ However, this thesis argues that the need to control the use of body parts and have remedies for breaches necessitates a legal framework.

It may be more difficult to provide an individual with a share of the profits than if researchers work with a patient advocacy group. ${ }^{140}$ Clearly, demands must be reasonable in relation to the contributions, the likely benefits and the risks. If a contribution-based formula was adopted, the inventor would receive the major share of the profits. Sources may prefer to influence access, pricing, ownership and control of products and treatments, rather than receive payment.

Harrison claims that neither the necessary public debate nor fully informed individual choice is possible, if most contributors are unaware that their tissue might be used to generate profit. ${ }^{141}$ She suggests that the calculation of compensation should be based on the material's relative scientific and commercial utility in research and development. ${ }^{142}$ Thus, Moore would have a strong case for compensation, because his contribution was indispensable for the discovery, whereas the Canavan families would have a lesser claim because their biological contributions were aggregated with many other samples with similar characteristics, and so their reward should be the collective or public benefit derived from the availability of new diagnostic tests or healthcare treatments. ${ }^{143}$

These arguments suggest an apportionment of the benefits between the sources and the inventor is justifiable, with the greater proportion available to the party providing the intellectual input. ${ }^{144}$

\section{B Control}

As already discussed, a personal property paradigm would operate in tandem with existing laws relating to autonomy, confidentiality and privacy. Property interests add to these the ability to empower individuals and communities and provide ongoing control and thus, moral and legal influence over body parts. Members of the Native American Havasupai Tribe claimed they felt violated and stigmatised after supplying samples for diabetes research and then having scientists

\footnotetext{
${ }^{138}$ K Berg "The Ethics of Benefit Sharing” (2001) 59 Clinical Genetics 240, 240.

${ }^{139}$ Jon F Merz and others "Protecting Subject's Interests in Genetics Research" (2002) 70 Am J Hum Genet 965, 970 .

${ }^{140}$ See the discussion of PXE International in chapter 3.

${ }^{141}$ Charlotte H Harrison "Neither Moore nor the Market: Alternative Models for Compensating Contributors of Human Tissue" (2002) 28 Am j law med 77, 82.

${ }^{142}$ Harrison, above, 83.

${ }^{143}$ See the discussion of these cases in chapter 3 .

${ }^{144}$ The possible amendments of patent law to allow the contributors to share in the benefits are explored in chapter 7 .
} 
use them without consent to study schizophrenia and inbreeding. ${ }^{145}$ Such interests can be harmed by research uses, even if the samples are anonymised. An example is Māori beliefs about harm from disruption of whakapapa, ${ }^{146}$ which could arise independent of any knowledge of the breach. Further concerns are the replication of cell lines for a prolonged period, and the inability to be fully informed about future unspecified research. A property approach allows the enforcement of restrictions on the type or extent of future use, which is one of the major problems of the current consent-based approach to the use of samples. ${ }^{147}$

In Washington University $v$ Catalona, ${ }^{148}$ Limbaugh $\mathrm{J}$ appeared to accept that sources either unconditionally gift materials to researchers, or the researcher obtains a property right over the tissue by entering into contractual arrangements, which may allow for conditional use. It was argued that patients would be unlikely to allow the use of their tissue if they had no control over how it might be used and no right to withdraw it. ${ }^{149}$

\section{Public Trust}

Public trust in doctors and researchers is essential to ensure ongoing participation in donation and research. The Medical Research Council found evidence of public cynicism towards the medical profession, although most people thought research was worthy and worthwhile. ${ }^{150}$ The perception that others are making unjust profits may result in reluctance to provide tissue. This mistrust may then extend to the therapeutic setting. ${ }^{151}$ Thus, it is important that the public are provided with a clear and justifiable explanation of the uses of donated tissue and the allocation of any significant benefits.

Cain argues that recognising property rights in human biological materials may diminish the fear that people feel when considering advancing biotechnology, because the property construct can mediate disputes over human biological materials. ${ }^{152}$ Consequently, she states that property rights would encourage organ donation, assure greater personal autonomy, diminish the international market in human body parts and diminish fears of the commodification of the human body. ${ }^{153}$

She asserts that if the public perceive that they are being exploited, the doctorpatient relationship will be damaged to a point where donations will reduce. Incidents

\footnotetext{
${ }^{145}$ R Dalton "When Two Tribes Go to War" (2004) 430 Nature 500; Tilousi v Arizona State University Board of Regents No 04-CV-1290-PCT-FJM (3 March 2005).

${ }^{146}$ See the discussion of concerns about genetic modification in chapter 5 .

${ }^{147}$ See the discussion of informed consent.

${ }^{148}$ Washington University $v$ Catalona (2006) US Dist LEXIS 22969, Limbaugh J. See the discussion in chapter 3.

${ }^{149}$ Testimony of Dr Ellen Wright Clayton referred to in: Lori Andrews "Who Owns Your Body? A Patient's Perspective on Washington University v Catalona (2006) J Law Med Ethics 398, 405.

${ }^{150}$ Medical Research Council Public Perceptions of the Collection of Human Biological Samples

(Wellcome Trust, London, 2000) < http://www.ukbiobank.ac.uk/docs/perceptions.pdf $>$ (last accessed

20 February 2006).

${ }^{151}$ See the discussion in chapter 3 of the "Guthrie tests".

152 Amy S Pignatella Cain "Property Rights in Human Biological Materials: Studies in Species

Reproduction and Biomedical Technology” (2000) 17 Ariz J Int'l \& Comp Law 449.

${ }^{153}$ Cain, above, 474.
} 
such as the "unfortunate experiment" at National Women's Hospital ${ }^{154}$ and the Greenlane Hospital heart library ${ }^{155}$ have contributed to mistrust of researchers in New Zealand. Despite this, there is strong support for measures to improve human health and reduce suffering. ${ }^{156}$

\section{Informed Consent}

Autonomy is a notable value in the context of medical treatment, as from it flow the interests in self determination and bodily integrity, which in turn lie behind the moral and legal rights to consent to and refuse medical treatment. The right to self-determination encompasses more than just a narrow interest in bodily integrity, as it includes a broader dignitary interest in the person's own body and extra corporeal body parts. This supports the contention that individuals should have the right to control excised tissues and cells. Informed consent was derived from malpractice cases involving non-consensual touching of the body. If a patient had not authorised treatment, or a doctor had performed treatment substantially different from that consented to, the patient had a cause of action for the tort of battery.

Consent is the dominant ethical concept in the Code ${ }^{157}$ and it requires disclosure and comprehension of information. The consent must be voluntary and the person consenting must be competent. Informed consent makes it possible for people to choose autonomously, but it does not guarantee or require that they do so. Consequently, it often amounts to no more than the right to choose or refuse procedures on offer, and the corresponding obligation on the medical professional not to proceed without consent.

Informed consent generally presupposes that consenting people are "in the maturity of their faculties", ${ }^{158}$ but their ability to give informed consent may be impaired if they are ill or stressed by decision making on behalf of another. As stated by O'Neill: ${ }^{159}$

These arise because informed consent is always given to one or another description of a proposal for treatment. Consent is a propositional attitude: it has as its object not a procedure or treatment, but rather one or another proposition containing a description of the intended procedure or treatment.

Informed consent can be superficial, related to the actual descriptions used, without comprehension of the consequences. Full disclosure of information is often practically unachievable and, even if it is attempted, it is unlikely that it would be

\footnotetext{
${ }^{154}$ Sylvia Cartwright The Report of the Cervical Cancer Inquiry (Government Printing Office, Auckland, 1988).

${ }^{155}$ D Gareth Jones and Kerry A Galvin "Retention of Body Parts: Reflections From Anatomy” 2, 2 $<$ http://anatomy.otago.ac.nz > (last accessed 21 April 2005); D Skegg "The Removal and Retention of Cadaveric Body Parts: Does the Law Require Parental Consent?” (2000) 10 Otago L Rev 425, 425. See also the discussion in chapter 2 .

${ }^{156}$ Toi te Taiao The Bioethics Council The Cultural, Ethical and Spiritual Aspects of Animal-to-Human Transplantation (Bioethics Council, Wellington, 2005) 27.

${ }^{157}$ Health and Disability Commissioner's Code of Health and Disability Services Consumers' Rights $<$ http://www.hdc.org.nz> (last accessed 1 March 2006). Right 6 is the Right to be Fully Informed and Right 7 is the Right to Make an Informed Choice and Give Informed Consent.

${ }^{158}$ Mill On Liberty as referred to in Onora O'Neill Autonomy and Trust in Bioethics, The Gifford Lectures University of Edinburgh, 2001 (Cambridge University Press, Cambridge, 2002) 43.

${ }^{159}$ O’Neill, above, 43 (emphasis in the original).
} 
fully understood. With the development of new biotechnologies, such as reproductive and genetic technologies, new choices and wider ranges of choices are probable, although not necessarily matched by greater cognitive involvement in consent.

Despite these issues, it is commonly accepted that people undergoing medical treatment should give informed consent. Such treatment often involves the collection of biological material. If the material is destroyed after the treatment, it could be argued that destruction was included implicitly in the consent to undergo the procedure. If the material is stored and later used in research, it could be argued that a donation takes effect when there is a transfer of property coupled with an intention, often implied, to make the gift. An alternative construct is that the material has been abandoned and, consequently, property passes to the researcher or hospital authority who obtains possession of it. In either case, the patient has no further interest in it.

However, consent to medical treatment does not, in itself, imply consent to further research uses of such material. It is true that most people do not expect the return of such material. ${ }^{160}$ Despite this, they may oppose research use because of objections that others might profit from their tissues and cells, or because of ethical or cultural concerns about the type of research.

\section{$1 \quad$ Bodily integrity}

English law has for many years recognised that everyone has a right to bodily integrity - the right to exclusive possession and use of their own bodies as against everyone else. This right derives from the concept of autonomy, which in turn is closely linked to human dignity. ${ }^{161}$

In medical law, bodily integrity is the means to protect autonomy and is protected by the torts of trespass to the person or negligence. ${ }^{162}$ Informed consent is premised on the right to self-determination, a right that has been interpreted narrowly as resting solely on the person's interest in bodily integrity. ${ }^{163}$

Persons who consent to medical treatment have already consented to the physical invasion of their bodies. The subsequent use of their body parts does not further threaten their bodily integrity. The consent related to the removal of certain materials and that is what has happened, so the right to control their own body has not been violated. Bodily integrity focuses on the need to inform the patient about the risks of the procedure and, as the removal of body parts in the course of normal treatment does not increase the risk, informed consent would not require the further

\footnotetext{
${ }^{160}$ Health and Disability Commissioner above, Right 7(9) "Every consumer has the right to make a decision about the return or disposal of any body parts or bodily substances removed or obtained in the course of a health care procedure."

${ }^{161}$ I Kennedy and A Grubb Medical Law (3ed, Butterworths, London, 2000) 575; Rees v Darlington Memorial Hospital NHS Trust [2004] 1 AC 309 (HL) 349 (Lord Millet).

${ }^{162}$ Re F (Mental Patient: Sterilisation) [1990] 2 AC 1 (HL) 72 (Lord Goff).

163 Sharon Nan Perley "Note: From Control Over One's Body to Control Over One's Body Parts: Extending the Doctrine of Informed Consent” (1992) 67 NYUL Rev 335, 346.
} 
disclosure of the fate of these parts. ${ }^{164}$ However, the proposed property-based legislation would to allow the source ongoing control.

\section{Dignity}

Perley argues that informed consent should be extended by interpreting the right of self determination as including an individual's right to dignity. ${ }^{165}$ She points to the example of the permanently insentient person who no longer has any interest in whether their body continues to live or not, yet an assault upon that person's dignity causes injury. ${ }^{166}$ Thus, an interest in one's dignity extends beyond the physical integrity of the body itself, to the values an individual holds. People have an interest in knowing their body parts will not be used contrary to their beliefs, so they should have the right to consent or refuse consent to the use of body parts and put restrictions on the use of them.

Perley proposes a remedy if the patient could prove the doctor failed to disclose information about the use of body parts and, had the information been given, consent to research use would have been refused. ${ }^{167}$ Damages would be related to the emotional injury suffered. However, at the time of excision, no research use may be envisaged by the treating doctor. Additionally, the loss may not be confined to emotional harm and may include loss of the profits or loss of the ability to control the cost and availability of tests and treatments.

The Convention on Human Rights and Biomedicine is predicated on a basic premise of respect for human dignity. ${ }^{168}$ Similarly, The Universal Draft Declaration on Bioethics and Human Rights provides: "Human dignity, human rights and fundamental freedoms are to be fully respected." 169 However, some bioethicists believe that human dignity has little to contribute to ethical advancement, if it simply acts as a way of expressing concern about some new possibility in science or medicine. ${ }^{170}$ Brownsword states: "What we need is a defensible concept of human dignity as the basis on which human rights and human virtue are founded." ${ }^{171} \mathrm{He}$ points out that human dignity is dominated by two ideologies. One is that human dignity is the foundation of human rights and the basis of individual autonomy. The other is that certain procedures are intrinsically wrong, as they compromise human

\footnotetext{
${ }^{164}$ Allen B Wagner "The Legal Impact of Patient Materials Used for Product Development in the Biomedical Industry" (1985) 33 Clinical Res 444, 446 arguing that as there is no further risk to the patient, tissue may be used for research without further consent.

${ }^{165}$ Perley, above, 347.

${ }^{166}$ See the discussion of such interests in chapter 4.

${ }^{167}$ Perley, above, 362.

${ }^{168}$ Convention for the Protection of Human Rights and Dignity of the Human Being with regard to the application of Biology and Medicine: Convention on Human Rights and Biomedicine (4 April 1997). CETS No: 164. "Parties to this Convention shall protect the dignity and identity of all human beings and guarantee everyone, without discrimination, respect for their integrity and other rights and fundamental freedoms with regard to the application of biology and medicine."

${ }^{169}$ Universal Draft Declaration on Bioethics and Human Rights, Article 3 (a).

${ }^{170}$ Roger Brownsword "Stem Cells, Superman, and the Report of the Select Committee" (2002) 65 MLR 568, 576.

${ }^{171}$ Brownsword, above, 576.
} 
dignity. ${ }^{172}$ Thus, dignity can provide humans with rights against one another, but superimposed upon such rights are concepts of responsibility, in light of human vulnerability.

Public policy might determine that the proposed framework is insufficient to protect human dignity in some situations, and consequently, there may be a need to restrict the retention and use of body parts. For example, unfettered autonomy has not been allowed in assisted reproduction. ${ }^{173}$ The arguments supporting such regulation include the welfare of the future child and public policy around issues such as surrogacy. ${ }^{174}$ However, this thesis argues that if property rights confer better control to people over the future disposition of their bodies after their death and their excised body parts during their lives, in general, their dignity will be enhanced, rather than diminished.

Chill research?

Research is socially beneficial and some commentators argue that a need to obtain and retain individual consent for the use of every retained biological sample might chill research and, potentially, cause researchers who did not provide the treatment to be at risk of liability. ${ }^{175}$ Others argue that property rights would stimulate research by providing incentives for otherwise reluctant or indifferent sources to supply material. ${ }^{176}$ There would be administrative requirements, but these must be weighed against the rights of the sources and the importance of preserving the trust and willing involvement of the public, both in organ transplantation and in research. Uncertainty about how body parts will be treated is a threat to continuing developments in biotechnology. A property approach would increase certainty by applying a well developed system of law, even if public policy necessitates restrictions on commercialisation.

\section{$4 \quad$ Third parties}

A major weakness in reliance on informed consent alone is that it does not effectively deal with researchers who obtain body parts from other researchers or biobanks and those who formulate a research use after obtaining them from the sources. This thesis argues that the property construct incorporates consent, which will remain the main mechanism by which human sources transfer their interests in biological materials. The availability of remedies such as conversion will impose an obligation on researchers to check the provenance of research materials. Such a requirement has been proposed by the Ministry of Health for established human embryonic stem cells. ${ }^{177}$ It is likely that researchers who obtain biological material

\footnotetext{
${ }^{172}$ The United Nations has this view of reproductive cloning. United Nations General Assembly, Declaration on Human Cloning, 8 March 2005. See also UNESCO Universal Declaration on the Human Genome and Human Rights 1997, article 11.

${ }^{173}$ Human Assisted Reproductive Technology Act 2004.

${ }^{174}$ Note that wider consideration of assisted reproduction is beyond the scope of this thesis.

${ }^{175}$ See the discussions about the development of the Human Tissue Act 2004 (UK) in chapter two and the amendment to Right 7(10) of the Code of Rights in chapter 3.

${ }^{176}$ G Laurie Genetic Privacy A Challenge to Medico-Legal Norms (Cambridge University Press, Cambridge, 2002) 324.

${ }^{177}$ Ministry of Health Guidelines on Using Cells from Established Human Embryonic Stem Cell Lines for Research Discussion Document (Ministry of Health, Wellington, 2005$) 42$.
} 
from biobanks will protect themselves from liability by relying on generic "blanket" consent or "authorisation". ${ }^{178}$

\section{ARGUMENTS AGAINST A PROPERTY CONSTRUCT}

\section{A Economic Inefficiency}

It has been argued that property rights could require researchers to engage in costly and time-consuming negotiations with numerous sources, or risk failing to secure clear title to the samples on which their products and patents were based. Researchers could face considerable transaction costs in locating and negotiating compensation arrangements with each individual source and, as studies may involve samples from sources worldwide, the complex and protracted negotiations might discourage research. Additionally, tissue is frequently obtained from other researchers or biobanks and the identities of the sources are unknown.

Tissue samples are often acquired in clinical situations, before research applications have been determined, or at an early stage of development of the research proposal. At this stage, it would be difficult to predict the ultimate commercial utility of any products that might result from the research. There would be a particular risk to scientists in the non-profit sector, who do not necessarily plan to commercialise their findings. In many cases, the material would never be used in a commercially profitable product and the costs involved in acquiring the rights to the samples might render the research impractical. ${ }^{179}$ Generic consent forms would overcome the need to re-contact sources to seek consent once research information is available.

Heller and Eisenberg assert that inefficiencies can result from excessive protection of individual property rights in biomedical research. ${ }^{180}$ They argue that the "anti- commons" arises when people hold too little in common, so that too many people have a private right to prevent others from using property of mutual interest. ${ }^{181}$ Biotechnology companies would need to strike a separate bargain with every person whose intellectual or tangible property might be needed to produce a commercial product. Thus, it would be better if fewer property rights were recognised.

Harrison argues that it is important to separate concerns about efficiency from differences in strategic or policy goals. ${ }^{182}$ Each party has a strategic interest in obtaining an acceptable financial return, while retaining the long term goal of developing new and better healthcare products. Individual tissue donors may be influenced by financial considerations, as well as particular concerns about research into the cure, treatment or prevention of diseases. She states: ${ }^{183}$

\footnotetext{
${ }^{178}$ Se the discussion in chapter 8 .

${ }^{179}$ Robert J Levine "Research That Could Yield Marketable Products from Human Materials: The Problem of Informed Consent" (1986) IRB 6, 6.

${ }^{180}$ Michael A Heller and Rebecca S Eisenberg "Can Patients Deter Innovation? The Anticommons in Biomedical Research” (1998) 280 Science 698, 698.

${ }^{181}$ Heller and Eisenberg, above, 699.

${ }^{182}$ Charlotte H Harrison "Neither Moore nor the Market: Alternative Models for Compensating Contributors of Human Tissue" (2002) 28 Am j law med 77, 86.

${ }^{183}$ Harrison, above, 87.
} 
In a market that serves the dual purpose of medical care and entrepreneurship, the extent of protection afforded to a tissue contributor's non-economic interests is a public policy question...It should be considered in conjunction with, but not subsumed by, concerns about financial returns and efficiency.

She suggests that the solution is to adopt non-market mechanisms for assessing value and transferring compensation to contributors of human tissue. The values would be determined by predictable standards after the commercial usefulness of a sample had been demonstrated in research and development, and only for those relatively few samples demonstrating a certain level of utility. She states: ${ }^{184}$

Standards for assessing utility could be set through the political process and interpreted in particular circumstances by an administrative agency or tribunal.

Bovenberg argues that the most equitable solution may be for the government to levy taxes on the corporate income generated by the biotechnology industry and redistribute the profits, subject to democratic control. ${ }^{185}$ New Zealand has a largely state funded health system. It could be argued that if individuals were able to claim a portion of the profits from inventions the solidarity of the system could be undermined, because the costs of treatment are largely funded by taxation. ${ }^{186}$ However, the same argument could be applied to anyone who supplied goods or services to the government, while also benefiting from using them.

Sources should have the option of negotiating on their own behalf or choosing that negotiations be conducted on a group basis by a patient group or an independent agency. ${ }^{187}$ Researchers would be required to keep track of sources, cell lines, the source's contribution to each cell line and the role of each cell line in developing end products. ${ }^{188}$ Although the studies and applications may take some years, careful record keeping should be part of good research practice, and maintenance of adequate records is relatively straightforward with use of computer databases.

It is likely that the sources' body parts would be transferred by way of a standard form, which would include the conditions, such as any financial arrangements. In most cases an individual's contribution would not be vital for a particular research project, however if it was, or if insufficient donors are prepared to accept the conditions, a more acceptable offer would be required. ${ }^{189}$

\section{B Commodification of the Person}

\footnotetext{
${ }^{184}$ Harrison, above, 88 .

185 Jasper A Bovenberg Property Rights in Blood, Genes and Data (Martinus Nijhoff, Boston, 2006) 138.

${ }^{186}$ Bovenberg, above, 137.

${ }^{187}$ See the discussion in chapter 8.

${ }^{188}$ A similar structure is proposed by the Ministry of Health in its proposed Guidelines for Using Cells from Established Human Embryonic Stem Cell Lines for Research (Ministry of Health, Wellington, 2005) 42. Researchers would be required to provide evidence that excess IVF embryos were used to create cell lines and also evidence details of the consent process.

${ }^{189}$ See the discussion in chapter 7 .
} 
One reason this thesis argues for recognition of a property interest in body parts is to enable sources to control the uses of and share in the profits made from the utilisation of body parts. However, many people feel discomfort with the concept of financial value being attributed to the human body and its parts, because such concepts are incompatible with human dignity and breach their sense of the significance of the human body. They argue that the dignity of a human being is diminished if the body is treated like a commodity that can be traded in exchange for money. Commodification is seen as a type of objectification or reductionism, which may lead people to see human beings as "repositories of body parts with a market worth rather than entities with...dignity.", "190

Despite this, the existence of markets for body parts does not necessitate that market prices are the only measure of their worth. Money is only one dimension of human interaction and valuing, and recognition of the monetary value of body parts may increase the level to which we value them. It is commonly argued that, as the law should prevent the sale of biological material, the material can only be classified as incomplete property. However, property rights do not need to be complete in order to be able to be protected, ${ }^{191}$ as the material could still be considered personal property carrying "sticks" from the bundle of rights. ${ }^{192}$ The legislation would clarify which incidents of ownership are removed from the bundle. ${ }^{193}$ However, if most of the rights normally associated with property were eliminated, then, at some point, there would be insufficient remaining rights to sustain a property interest. ${ }^{194}$

If body parts were classified as market-inalienable, as proposed by Radin, ${ }^{195}$ they could be given away, but not sold ${ }^{196}$ and sources would retain the right to exercise ongoing control. The problem with this approach is that property rights could not be invoked as the basis for profit sharing.

In most countries, a market-based system of organ trade is considered to be unethical. In the United States, the sale of blood and sperm is permitted, but not the sale of non-renewable body parts. In Australia, there are prohibitions against trading in such tissue, ${ }^{197}$ whereas in New Zealand there is, as yet, no such specific prohibition on the sale of organs, although such a contract may be void as being contrary to public policy. The Ministry of Health considered various arguments for and against the sale of tissues and concluded that such commercialisation should not be allowed in New Zealand. ${ }^{198}$ The Human Assisted Reproductive Technology Act 2004

\footnotetext{
${ }^{190}$ Stephen R Munzer “An Uneasy Case against Property Rights in Body Parts” (1994) 11 Social Philosophy \& Policy 259, 286.

${ }^{191}$ Catherine M Valerio Barrad "Comment, Genetic Information and Property Theory" (1993) 87 Nw

U L Rev 1037, 1059-60.

192 Barrad, above, 1058.

${ }^{193}$ See chapter 8 where the framework recognises property rights but prohibits certain forms of commercialisation on public policy grounds.

${ }^{194}$ This was argued in Moore $v$ Regents of the University of California (1990) 793 P 2d 479, 491-2 (Sup Ct Cal). See the discussion in chapter 3.

${ }_{195}$ Margaret Radin "Market- Inalienability” (1987) 100 Harv L Rev 1849, 1853.

196 This is the outcome from the cases discussed in chapter 3.

${ }^{197}$ See Human Tissue Act 1985 (Tas) Part IV; Transplantation and Anatomy Ordinance 1978 (ACT), s 27; Human Tissue Transplant Act 1979 (NT); Transplantation and Anatomy Act 1979 (Qld); Human Tissue Act 1982 (Vic); Human Tissue Amendment Act 1987 (Vic); Human Tissue and Transplantation Amendment Act 1987 (WA); Human Tissue Act 1982 (NSW).

${ }^{198}$ Ministry of Health, above, 95-97.
} 
prohibits valuable consideration for the supply of a human embryo or human gamete $^{199}$ and the proposed human tissue legislation will contain a prohibition of the sale of organs.

Price argues: 200

Objections to selling body parts for transplantation are most commonly voiced independently of the issue of "property rights", however, and instead insist that the donation of organs should be based on altruism.

He argues that payment is not necessarily incompatible with altruism and, in any event, living organ donation is commonly not truly altruistic, as it is based on selfinterest, as the donor may consent primarily to preserve the family unit.

There are concerns that commercialising the supply of organs would lead to the harvest of organs from the vulnerable and a loss of respect for persons. If the recipient of an organ pays the donor or the donor's family directly, the poor may be compelled, through economic necessity, to donate organs to the more financially advantaged. This might increase the number of diseased organs being made available. The same concerns were expressed about the sale of blood in the United States. This fear centres on the belief that the poor, especially people who are malnourished, alcoholics, or drug users, might comprise the largest group of donors. Such donors could have an incentive to misrepresent their health status. ${ }^{201}$

Similarly, in the United Kingdom the HFEA has permitted "egg sharing" whereby parents who agree to donate eggs to other couples or for research obtain fertility treatment at a reduced cost. ${ }^{202}$

If there were a market in organs, then free donations might reduce, as people are less likely to donate an item for which payment is available, but monetary value for organs may result in increased availability. Testing might not always be able to identify defective organs to ensure they are not transplanted into unwary recipients. ${ }^{203}$ However, the quality of organs would not necessarily decline, as suppliers of potentially poor quality organs would not be competitive in the market. ${ }^{204}$ These concerns can be countered by the argument that an increased supply of body parts would be a societal good and the difficulties could largely be addressed by assessment and testing of donors.

Cain suggests that as altruistic organ donation has proved unsuccessful in maintaining a sufficient supply of organs, controlled commercialisation is necessary to increase the supply, but this should exclude paid living donation and protect

\footnotetext{
${ }^{199}$ Human Assisted Reproductive Technology Act 2004, s 13.

${ }^{200}$ David Price Legal and Ethical Aspects of Organ Transplantation (Cambridge University Press, Cambridge, 2000) 9 (emphasis in original).

${ }^{201}$ J Brams "Transplantable Human Organs: Should Their Sale be Authorised by State Statutes?" (1977) 3 Am J Law and Med 183, 192.

${ }^{202}$ As there is only one State funded cycle per couple and these are not always available, poorer parents may be unable to access fertility treatment unless they agree to donate.

${ }^{203}$ However this is no different from the present situation.

${ }^{204}$ A purchaser would tend to select a vendor who has been tested and the results indicate as far as possible that the donor is healthy.
} 
indigent donors. ${ }^{205}$ She argues that as an international "black market" in organs and tissue already exists, regulation would provide controls to protect the vulnerable. ${ }^{206}$ The recognition of property rights would also promote autonomy, by allowing human sources to participate in the commercial development of their biological materials.

Munzer argues that the mere assignment of value to a body part does not necessarily entail commodification. He concludes that commodification is not created if the amount to be paid for a particular body part is assessed on a collective, non-market basis rather than in private negotiations, under a liability rule, rather than a property rule. $^{207}$

Commerce already pays a central role in the distribution of human biological materials. $^{208}$ Once they have been donated, they are bought and sold throughout the medical industry, but the property rights vest in the secondary individuals and institutions, rather than the donor. Such property rights provide an incentive for researchers and pharmaceutical companies to do research that will prove commercially profitable, but this does not necessitate that individuals be denied property rights.

There is no obvious public policy justification for failing to generously compensate living organ donors for expenses and loss of income. Similarly, a statefunded funeral benefit payable to the estates of deceased donors would not be sufficiently significant to equate to families selling their relatives' bodies and could be justified as social recognition of a worthy act.

It is not the purpose of this thesis to explore the opposing arguments mounted by a large number of commentators regarding the sale of organs, nor to argue in favour of a market for transplantable organs, because it is clear that such a move would be contrary to public policy. However, it is argued that sources should have the ability to control the uses of their body parts and make contractual arrangements to share in the profits arising from patenting products based on them and this is best achieved by treating body parts as property. ${ }^{209}$ It would be possible to devise controls, to avoid the degradation of individuals or of personhood in general, as limitations on uses of property are common in other situations. ${ }^{210}$

\section{$1 \quad$ Futures market}

Some commentators suggest that a futures market would be a more acceptable form of commercialisation than sales of body parts. A futures market for bodily organs would involve a contractual commitment being entered into by the source of the organs, to make those organs available to the other contracting party for

\footnotetext{
${ }^{205}$ See the discussion of commercialisation of body parts above.

${ }^{206}$ Amy S Pignatella Cain "Note: Property Rights in Human Biological Materials: Studies in Species Reproduction and Biomedical Technology” (2000)17 Ariz. J Int'l \& Comp Law 449, 478.

207 Stephen R Munzer "An Uneasy Case against Property Rights in Body Parts" (1994) 11 Social Philosophy \& Policy 259, 281.

${ }^{208}$ For an indication of the scale of the black market in organs see

$<$ http://sunsite.berkeley.edu/biotech/organswatch> (last accessed 14 March 2004).

${ }^{209}$ See chapter 7.

${ }^{210}$ Susan Rose-Ackerman "Inalienability and the Theory of Property Rights" (1985) 85 Colum L Rev 931, 931. See the proposed jurisdiction of the Human Tissue Authority in chapter 8.
} 
transplantation, or other purposes, on the death of the source. They argue that the sale of an organ to be removed while the source is still alive should be prohibited and that the organ buyer under a futures contract would be under no obligation to harvest those organs upon the death of the source, or to dispose of the cadaver, but would merely have an option right to choose to harvest the organs.

An important issue would be whether organ buyers would make current payments to sources, in exchange for obtaining future rights to organs, or whether payments would only be permitted to be made to the estate of the deceased person. The payment could be cash, lower health premiums, or a payment to a charity. Alternatively, payment or a state-funded funeral benefit could be given to the successors, once the donor died in a sufficiently healthy state for the organs to be useful, and the required consents were given. The amounts paid to sources for entering into futures contracts could be set by competitive forces, or there could be regulatory restrictions on the contracting process.

One issue is to determine whether the hospital or other institution in which the source dies would be obliged to notify the organ buyer of the death and to preserve the organs until they were able to be harvested. Legislation could specify that a governmental agency would be the sole buyer, or a number of private or public entities could be allowed to compete to obtain futures contract commitments. It would also have to be decided to what extent a secondary resale market in future organ rights might be permitted.

Crespi has proposed a structure for a futures market in bodily organs. ${ }^{211}$ Issues arising include the status of such a contract and the implications of the contractual obligations, should the organs not be used. Although individuals may contract to sell future goods, such contracts do not in themselves transfer property rights. Legal title to property cannot ordinarily be transferred until it comes into existence. Under the proposed framework, that would be at the time of the separation of body parts from the living person, or the death of the source. Kennedy and Dworkin assert that as a purported transfer of future property may only amount to a contract to transfer the title once the property is created, the title must first vest, at least momentarily, in the donor. ${ }^{212}$

A futures market would be unlikely to markedly increase the rate of organ donation in New Zealand because, generally, the donor must have been declared dead in an intensive care unit and maintained on a ventilator. There are comparatively few intensive care beds in New Zealand, compared to other Western countries. ${ }^{213}$ The practice of limiting intensive care if patients are considered to have a poor prognosis restricts the rate of organ donation. Nevertheless, the structure proposed in this thesis would facilitate futures contracts and if the potential to reduce public health costs by increased transplantation is recognised, a policy decision may be made to direct additional resources toward intensive care.

\footnotetext{
${ }^{211}$ Gregory S Crespi "Overcoming the Legal Obstacles to the Creation of a Futures Market in Bodily Organs" (1994) 55 Ohio St L J 1, 35.

${ }^{212}$ I Kennedy and G Dworkin "Human Tissue: Rights in the Body and its Parts" (1993) 1 Med L Rev 291, 302.

${ }^{213}$ New Zealand has 69 intensive care beds per million people, compared to France with 384, Australia with 88, Spain with 148 and the United States with 305.
} 


\title{
C Professional Relationships
}

Various scandals involving body parts have resulted in public mistrust in researchers, ${ }^{214}$ as is demonstrated by the parties in Moore ${ }^{215}$ and Greenberg. ${ }^{216}$ There is a perception that consent to donation of body parts could result in reduced efforts to keep the human source alive, or unnecessary extension of the dying process. Physicians may be seen to have conflicts of interests, although this could be reduced by separating the persons involved in treatment from those involved in research or transplantation. Dickens states: ${ }^{217}$

\begin{abstract}
A prudent safeguard against the appearance of abuse, and also against the legal presumption of undue influence lies in consent for donation for research being sought by a stranger to the patient who does not appear to be an authority figure or to have any influence over the patient's treatment or daily comfort. The possibility remains, however, of the physician taking extra tissue or, for instance, blood required for diagnosis to serve his interests in research or instruction.
\end{abstract}

A similar approach is commonly adopted when seeking consent for organ donation, with the process being removed from the treatment of the donor.

As already considered, there is a level of public distrust of science, resulting from perceived misconduct by researchers. ${ }^{218}$ This is more likely if the public perceive that sources are unfairly excluded from benefits, or otherwise disadvantaged, such as being unable to afford tests because of the effect of licensing agreements. Secondary uses of material supplied for medical diagnosis or treatment may impact on the therapeutic relationship, especially if it is perceived that there are commercial benefits from such use. Similarly, concern about the potential for unconsented secondary uses of the "Guthrie test" samples has resulted in increasing numbers of people wishing to obtain the return of the sample cards. ${ }^{219}$ It is essential to devise structures to ensure that the public maintain confidence that treatment decisions are not compromised by the potential for secondary uses of tissue or organ harvest.

\section{Altruism and the Common Good}

It is commonly believed that people should donate organs or participate in medical research for altruistic reasons, and that a focus on the sharing of financial benefits could attenuate people's willingness to participate for idealistic reasons. Price suggests the emphasis on altruism is a source of ambiguity and confusion and is based, erroneously, on the work of Titmuss, which related to blood donation. ${ }^{220}$

\footnotetext{
${ }^{214}$ See the discussion in chapter 2.

${ }^{215}$ Moore v Regents of the University of California (1990) 93 P 2d 479, 484 (Sup Ct Cal).

${ }^{216}$ Greenberg and others v Miami Hospital Research Institute and others (2003) 64 F Supp 2d 1064.

${ }^{217}$ Bernard Dickens "The Control of Living Body Materials" (1977) 27 U Toronto L J 142, 151.

${ }^{218}$ Such as the Greenlane Hospital heart library and the "unfortunate experiment" at Auckland

Women's Hospital. See the discussion in chapter 2.

${ }^{219}$ See the discussion in chapter 3.

${ }^{220}$ David Price Legal and Ethical Aspects of Organ Transplantation (Cambridge University Press, Cambridge, 2000)
} 
The acknowledgment of property rights would not necessarily end gratuitous gift-giving, as human sources could to choose whether to make a gift of biological materials, or to enter into some alternative arrangement. ${ }^{221}$ The common good would be best served by increased public involvement in organ and tissue donation. Price suggests that: ${ }^{222}$

[G]reater regard for the autonomy of the participants would yield ethical goods both in increasing protection and respect for involved individuals and in reducing suffering and mortality through organ failure.

This thesis argues this is more likely if the source is able to control excised body parts, negotiate profit sharing and have remedies for misappropriation.

\section{CONCLUSIONS}

This chapter argued that a legislative framework incorporating property rights over excised body parts, would be more protective of the interests of sources. Some concepts of property were applied to body parts and it was concluded that organs and body parts assume a different nature once removed from the whole body, so for example, a kidney inside a person's living body forms an integrated part of the wholeit is perfused with the person's blood and it interacts with the entire system. Once it is removed, it assumes a different character and becomes an inert tangible item. Additionally, in order to have body parts removed, a person must undergo a process which is, to some extent, invasive and involves pain and suffering or inconvenience. A doctor generally removes the parts, but that work is done as an agent on the source's behalf and should not lead to property rights that would trump those of the source, unless ownership is transferred or there is clear evidence of abandonment. A dead body is clearly a different thing from a living person so, at the point of death, ${ }^{223}$ it becomes a tangible item, albeit with significance for the living. ${ }^{224}$

The development of the dominance of autonomy in western bioethics was outlined and it was argued that consent has come to be seen as being synonymous with autonomy and, as such, is an individualistic and atomistic concept, as it focuses on the individual and the furtherance of a person's interests. It was argued that the ethical value of autonomy is more than informed consent, as autonomy reflects various different aspects of personhood that are worthy of respect, such as choice, independence, freedom of action, self-governance and control. Thus, it is suggested that equating autonomy with consent restricts the concept of autonomy, which is best perceived as a universal ethical good.

To acknowledge that people have property rights in body parts would enhance the value of individuals and their autonomy. At present, researchers or institutions that develop products utilising human material acquire property rights, but the sources are precluded from benefiting from the commercialisation of their biological materials. Much of the tissue used in biotechnology research is acquired by express donations,

\footnotetext{
${ }^{221}$ See the discussions in chapter 3 about the Canavan families, who were concerned to ensure availability of the tests and about living donor transplantation.

${ }^{222}$ David Price Legal and Ethical Aspects of Organ Transplantation (Cambridge University Press, Cambridge, 2000) 466.

${ }^{223}$ See the discussion of death in chapter 4.

${ }^{224}$ See the critique of the "no property in a dead body" rule in chapter 2.
} 
or obtained in the course of medical treatment. This tissue is, supposedly, abandoned by the sources, even though they may be unaware of its potential value. ${ }^{225}$

The increasing need for body parts for transplantation and research provides an impetus to refine the existing ethical framework, to ensure better respect and protection for sources and their families. There would still be a place for altruistic donation, but property interests would allow negotiation of a share in the profits and on-going control over the uses of the material. An increased willingness to donate should result, thus benefiting society.

${ }^{225}$ As in the case of John Moore. See Moore v Regents of the University of California (1990) 793 P 2d 479 (Sup Ct Cal) discussed in chapter 3. 


\section{Chapter 2}

\section{BODY PARTS FROM THE DEAD}

Our son David was all heart, and he was buried without his heart.... He isn't resting in peace. He's resting in pieces. ${ }^{1}$

\section{INTRODUCTION}

The next two chapters consider dead and living bodies separately. This structure is adopted, not as an assertion, but because the proposed New Zealand Human Tissue Bill makes this distinction. Also, although courts have indicated that cadavers may be the subject of property because of an application of human skill, similar logic has not been applied to the creation of cell lines from cells derived from the living body. ${ }^{2}$

Corpses have prospective significance for living persons and emotional significance for families, so treatment of the corpse in a manner that is incompatible with personal or cultural values may be disturbing to persons with emotional ties to the deceased. Consequently, it appears paradoxical that the law enforces testamentary dispositions of property after death, while the common law asserts that no one has a property interest in a dead human body, or its composite parts. ${ }^{3}$

The use of cadavers is controversial, partly because of the ambiguous legal status of the corpse. From a consequentialist point of view it is desirable, or even morally necessary, to use corpses to prolong lives or facilitate medical research, as the dead have no preferences or interests. However, duties regarding the dead are indirectly duties towards living persons, who do have preferences about how the dead should be treated. These may be the preferences of relatives of the deceased, or those of living persons about procedures to be carried out on their bodies after death.

Consequentialists argue that it would benefit society if people could be convinced that that the benefits of recycling corpses outweigh their, allegedly, irrational objections. Harris suggests that, as it is accepted that the need for an autopsy must outweigh the wishes of relatives, it is irrational to allow their preferences to take priority in organ donation. ${ }^{4}$ Feinberg denies the notion that organ collection causes psychological harm to dying people and their relatives. He considers that people who object to routine organ recovery are overly sentimental or superstitious, stating: ${ }^{5}$

\footnotetext{
${ }^{1}$ Tom Mashberg "Parents Sue Hospital for Harvesting Child’s Organs" (19 May 2003) Boston Herald Boston, 016.

${ }^{2}$ However the Human Tissue Act 2004 (UK), s 32(a) applies the work and skill exemption to tissue, irrespective of whether the source was alive or dead.

${ }^{3}$ With respect to the disposition of property, see the Wills Act (UK) 1837 (as amended). The executor of a deceased person is entitled to custody of the body and has a duty to bury it. Awa $v$ Independent News Auckland Ltd [1995] 3 NZLR 701, 710 (HC) Hammond J. Although a person may express wishes about the disposition of their body, these requests are not binding.

${ }^{4}$ John Harris The Value of Life: An Introduction to Medical Ethics (Routledge \& Kegan Paul, London, 1985) 119.

5 Joel Feinberg “The Mistreatment of Dead Bodies” (1985) 15 Hastings Cent rep 31, 36.
} 
It is difficult to understand how the thought of bodies having their organs removed before burial can be more depressing than the thought of them festering in the cold ground or going up in flames.

A contrary argument is that a person's interest in his or her body should only be lost to the State if a strong interest or need can be demonstrated and that society does not have an interest sufficient to justify the collective ownership of corpses. The emotional impact of such issues was demonstrated by the parents of the dead children involved in scandals at Alder Hey in the United Kingdom and Greenlane Hospital in New Zealand, who were intent on reclaiming body parts from deceased children.

As stated in chapter one, it is conceptually difficult to argue that living persons have property in their intact bodies. However, property concepts are more readily applicable to excised body parts and cadavers. A dead person cannot directly own anything, so it is argued that a regulatory framework for the control of body parts should permit a living person to appoint a representative, to whom a property interest in the corpse would pass at the appointer's death. ${ }^{6}$ That person would be required to carry out the deceased's express wishes as to the disposition of the body. If no such instructions were given, the representative would have decision-making authority. If the deceased had not appointed a representative, then the person specified in a priority list would assume the role, similar to intestate succession.

The legislation should specify the information to be provided to the person at the time of making the appointment and giving the instructions, to ensure that the decision is fully informed. ${ }^{8}$ The appointment process should be prescribed, similar to the appointment of an executor. ${ }^{9}$ The disadvantage of this proposal is the potential for offence to family members, but this thesis argues that if a property interest is acknowledged, then there is no conceptual coherence in permitting family members interests to trump the wishes of the deceased and the interests of potential recipients. It is acknowledged that this proposal may concern some Māori, as they have strong cultural views about death and the interment of the whole body and that the proposed framework should honour the provisions of the Treaty of Waitangi, particularly with regard to taonga. ${ }^{10}$

The respective positions of the representative and the possessor of the materials would be that a form of bailment would apply until the transplant or research use is complete. The hospital or researcher would obtain possessory rights to the materials, subject to the terms of the bailment established by the personal representative, who could take action if the materials were misused. Once organs were transplanted to another, they would become part of that person and no longer subject to property interests.

Part I of this chapter will outline some recent controversies regarding cadavers and consider potential procurement systems. It will examine the accepted view that there is no property in a dead body and consider whether quasi-property is

\footnotetext{
${ }^{6}$ The details of the framework are set out in chapter 8 .

${ }^{7}$ Administration Act 1969, s 77. Once a grant of administration was made, the administrator would assume the role of representative.

${ }^{8}$ See the discussion in chapter 8 .

${ }^{9}$ A will must be in writing, signed and witnessed.Wills Act 1837 (UK), s 4.

${ }^{10}$ Treasures. See the discussion in chapter 5 .
} 
an adequate solution. In Part II it will outline the current law with regard to dead bodies and demonstrate its conceptual incoherence. It will compare the United Kingdom Human Tissue Act 2004 (UKHTA) with the New Zealand Human Tissue Bill (HTB), to analyse whether either provide a solution to the issues addressed in this thesis and as a basis for the suggestion that both imply underlying notions of property.

\section{MODERN SCANDALS}

There have been a series of scandals in different countries regarding the retention of body parts. Additionally, concern has arisen about exploitation of research participants. ${ }^{11}$ These concerns have led to calls for benefit sharing and protection of indigenous resources. $^{12}$

\section{A United Kingdom}

In 1999, the public became aware of the retention and storage of dead children's body parts without parental consent. ${ }^{13}$ Initially, Alder Hey Hospital admitted retaining the hearts of 2,087 children. Later, it was discovered that other organs were removed during post-mortem examinations. ${ }^{14}$ Following an inquiry, it was determined that the general practice at Alder Hey was to remove every organ from every deceased child between 1988 and 1995. ${ }^{15}$ An official inquiry, involving a census of organ retention, found that at the end of 1999, 210 National Health Service trusts and medical schools were holding 104,300 organs, body parts and entire bodies of still-born babies and foetuses.

Many parents gave consent for "tissue" to be removed, not realising this could include organs and body parts. The report of the subsequent inquiry recommended that parents be informed of each organ retained and the purpose for which it is to be used. ${ }^{16}$ The implication was that parents have an interest in their children's bodies, whether or not the child was born alive. ${ }^{17}$ It recommended that when the next of kin sign the consent form they relinquish control, subject to retaining the right to specify how the material should be respectfully disposed of after completion of the purpose for which it was retained. In order to avoid repeated requests for consent, it recommended that further consent would not be necessary should the original research develop or diversify, or if new interests arose. ${ }^{18}$ It recommended a consent paradigm and did not specifically recommend recognition of property interests in

\footnotetext{
${ }^{11}$ Zbigniew Bankowski and Robert Levine (eds) Ethics and Research on Human Subjects: International Guidelines : Proceedings of the XXVIth CIOMS Conference, Geneva, Switzerland, 5-7 February 1992 (CIOMS, Geneva, 1993) 43; Leonard H Glantz and others "Research in Developing Countries: Taking 'Benefit' Seriously” (1998) 38 Hastings cent rep 38, 38.

${ }^{12}$ See the discussion in chapter 5 .

${ }^{13}$ Nigel Bunyon "Milburn Orders Inquiry into Baby Organ Scandal" (4 December 1999) The Telegraph London <http://www.telegraph.co.uk> (last accessed 7 October 2003).

${ }^{14}$ Tim Reid "Doctor Denies Storing Organs for Research" (4 December 1999) The Times, London $2 \mathrm{~W} 4$.

${ }^{15}$ House of Commons The Royal Liverpool Children's Inquiry Report (The Stationery Office, London, 2001) HC [session 2000-2001] 112-II <www.rlcinquiry.org.uk> (last accessed 10 September 2004).

${ }^{16}$ House of Commons, above, 22.

${ }^{17}$ See the discussion of personhood in chapter 4.

${ }^{18}$ These issues have been addressed in the Human Tissue Act 2004 (UK) discussed below.
} 
dead bodies and body parts, although the provisions of the resulting UKHTA do indicate an implicit acceptance of notions of property. ${ }^{19}$

The revelations resulted in a loss of confidence in the medical profession and an abrupt drop, in organ donations of up to 50 per cent, ${ }^{20}$ but the $2002 / 3$ figures showed some recovery. ${ }^{21}$ There were also reductions in research and other procedures using human tissue, including tissue acquired from pathological archives, and fewer hospital post-mortems performed. Donations of corpses for anatomical examination reduced and there was a substantial drop in the referral of brain specimens for examination across the United Kingdom. ${ }^{22}$

\section{B New Zealand}

Following the overseas organ retention disclosures, experts stated that these issues could not arise in New Zealand. Jane Zucollo, paediatric pathologist at Capital Coast Health, perhaps reflecting a common public perception, stated that the problems in the United Kingdom arose because “...we didn't remember the child was the property of the family....,23

Despite this, in 2002, Greenlane Hospital admitted that approximately 1,300 babies' hearts had been retained, in many cases without parental consent, between the 1950s and late 2001. The hearts were used for research and teaching. The majority were from deceased children who had congenital heart conditions, although there were also adult hearts from cases in which children with congenital heart conditions had survived until adulthood.

The hearts, which had been removed by pathologists at autopsy for further examination, were sent to Greenlane Hospital, where the specialists in cardiac morphology were based. They were then either returned, or kept at Greenlane for educational purposes. After 2002, a search by the Auckland District Health Board found specimens in a decommissioned laboratory building and also discovered that Labplus ${ }^{24}$ had stored limbs and other specimens, which were intended to be returned to families but had not been collected. Some unidentified skeletons were also used for teaching purposes. Additionally, it was found that the Christchurch School of Medicine had a teaching collection of over 3,000 organs, mostly obtained without consent since 1945 .

\footnotetext{
${ }^{19}$ See the discussion of the UKHTA later in this chapter.

${ }^{20}$ David Charter "Milburn Accused of Scaring Away Organ Donors" (6 February 2001) The Times London 4M4.

${ }^{21}$ UK Transplant <http://www.uktransplant.org.uk> (last accessed 3 December 2004). A six per cent increase in solid organ transplants, a four per cent increase in cadaveric donation, a two per cent increase in live donors and a six per cent increase in cornea donors on the previous year, but a five per cent decrease in heart donors.

${ }^{22}$ N Carr and others "The Autopsy: Lessons from the National Confidential Enquiry into Perioperative Deaths" (2002) 95 J Royal Soc Med 328, 329.

${ }^{23}$ Val Aldridge "Bodies of Evidence" (15 March 2001) The Dominion Wellington A4.

${ }^{24}$ The Auckland District Health Board pathology service.
} 


\section{United States}

There have been scandals in the United States involving anatomy departments, tissue banks, ${ }^{25}$ non-profit and for-profit private biotechnology companies ${ }^{26}$ crematoria $^{27}$ and medical schools. ${ }^{28}$ While some of these cases involve commercial interests, the underlying issue is the necessity to obtain human tissue for research, therapy and teaching. Although public support is strong for products and services that make use of human tissue, the distribution of the financial returns is controversial. ${ }^{29}$

The denial that sources have property interests results in the ironic outcome that they must act gratuitously, while subsequent transfers to transplant programmes, pharmaceutical companies, and the like, are commercial transactions. Donations of transplantable solid organs are made pursuant to the Uniform Anatomical Gift Act. ${ }^{30}$ The National Organ Transplant $\mathrm{Act}^{31}$ prohibits payments for any organ to be used in transplantation. ${ }^{32}$ However, the possession of transplantable organs can generate considerable amounts of money. Organ Procurement Organisations receive payment from transplanting hospitals for procuring organs from sources and delivering them to transplant programmes, pursuant to the system established and administered by the United Network for Organ Sharing. These payments are often called "acquisition fees." 33

The National Organ Transplant Act prohibits the "transfer of any organ for valuable consideration for use in human transplantation, if the transfer affects interstate commerce," but organ procurement organisations are permitted to receive "reasonable payments associated with removal and transportation." 34 In a 1993 study, the median "donor acquisition charges" billed to transplant patients ranged from approximately \$US12, 000 to \$US16, $000 .^{35}$

Transplant programmes provide these organs to patients as part of a package of transplant services and are paid considerable amounts for these services by

\footnotetext{
${ }^{25}$ Emily Waltz "The Body Snatchers" (2006) 12 Nature Medicine 487.

${ }^{26}$ M Katches, W Heisel and R Campbell "The Body Brokers: Parts 1-5” (16-20 April 2000) Orange County Register Orange County, California <http://www.ocregister.com> (last accessed 11 April 2005); Lori B Andrews and Dorothy Nelkin Body Bazaar (Crown Publishers, New York, 2001) 25.

${ }^{27}$ J McDonald "Mortician May Have Sold Body Parts" (22 February 2002) San Diego Union-Tribune San Diego <http://www.signonsandiego.com> (last accessed 1 April 2005).

${ }^{28}$ J Wampler "Body Parts Use by University of Kentucky Questioned” (25 February 2002) Kentucky Kernel University of Kentucky <http://www.kykernel.com/news> (last accessed 14 October 2004).

${ }^{29}$ James F Childress "Organ and Tissue Procurement: Ethical and Legal Issues Regarding Cadavers. Religious and Humanistic Beliefs, Attitudes and Practices" Warren Thomas Reich (ed) Encyclopaedia of Bioethics (2 ed, Macmillan, New York, 1995) 1854, 1866.

${ }^{30}$ Uniform Anatomical Gift Act (amended 1987), 8A ULA $\S 19$.

${ }^{31}$ National Organ Transplant Act, 42 USC § 273-274 (f).

${ }^{32}$ National Organ Transplant Act, above, $\$ 274$ (e).

${ }^{33}$ Roger W Evans "Organ Procurement Expenditures and the Role of Financial Incentives" (1993) 269 JAMA $3113,3114$.

${ }^{34}$ National Organ Transplant Act, above, § 274e.

${ }^{35}$ Evans, above, 3115-16.
} 
recipients and their insurance companies. ${ }^{36}$ Although the organ is not sold and patients only pay for medical services, the services have no value without the organ, which cannot be acquired in a separate transaction.

Changes in federal laws during the 1980s encouraged corporate investment in academic research, especially in potentially profitable areas of biotechnology. University medical researchers were permitted to profit from research they undertook, often using public funds. ${ }^{37}$ After the Supreme Court allowed the patenting of new life-forms, researchers and biotechnology companies moved to patent their findings. ${ }^{38}$ This meant claiming ownership of the cell lines and genes provided by research subjects. $^{39}$

Tissue donors commonly believe donations are a non-profit endeavour for the benefit of the community and are unaware that the collection, processing and distribution of tissue are a billion-dollar nation-wide business. ${ }^{40}$ There is no federal requirement that tissue banks disclose to families what will happen to the tissue they collect and the requirements of informed consent vary from state to state.

The Food and Drug Administration (FDA) is the federal agency responsible for the regulation of human cellular and tissue based products. It derives its regulatory authority from the Public Health Service Act, ${ }^{41}$ which relates to those regulations necessary to prevent the introduction, transmission or spread of communicable diseases from state to state, or from foreign countries into the United States. In the late 1980s and early 1990s, several examples of transmission of serious illnesses from tissue donors prompted attempts in Congress to pass comprehensive legislation regulating human tissue banks. ${ }^{42}$ However, the proposed legislation never became law and safety concerns have remained, recently regarding the theft and use of parts from cadavers. $^{43}$

\section{PROCUREMENT SYSTEMS}

There are a number of commonly proposed organ procurement systems and it is reasonable to employ the system that results in the largest pool of organs or research materials without violating human rights. Most jurisdictions require either the express or presumed consent of the deceased prior to death, or the express consent of a relative, to permit the harvest of transplantable organs. It is widely accepted that this respects the autonomy interests of the deceased, presumably on the basis that

\footnotetext{
${ }^{36}$ In 1994, mean charges for the first year following transplantation ranged from \$US116, 000 for a kidney transplant to \$US314, 000 for a liver transplant: Richard H Hauboldt Cost Implications of Human Organ and Tissue Transplantations, An Update 1996 (Milliman and Robertson Inc, Minneapolis, 1996) 27-28.

${ }^{37}$ Lori B Andrews and Dorothy Nelkin Body Bazaar (Crown Publishers, New York, 2001).

${ }^{38}$ Diamond $v$ Chakrabarty (1980) 448 US 303 (SC).

${ }^{39}$ See the discussion in chapter 7 .

${ }^{40}$ For example, the patent held by Amgen for the human erythropoietin gene, which codes for a protein needed by kidney disease patients, is worth more than US\$1.5 billion per year, because a genetically engineered treatment can be made from it.

${ }^{41}$ Public Health Service Act, 42 USC $§ 264$ (1994), s361.

42 Lynn Wagner "Tough Rules Urged for Tissue Banks" (1992) Mod Healthcare 17, 17.

${ }^{43}$ Michael Powell and David Segal "In New York, a Grisly Traffic in Body Parts: Illegal Sales Worry Dead's Kin, Tissue Recipients" (28 January 2006) Washington Post Washington A03.
} 
relatives can best reflect the wishes of the deceased or that they have a greater interest in the formerly living person than has anyone else.

This thesis argues for a system that would ensure that the wishes of deceased persons were respected, irrespective of the views of relatives. ${ }^{44}$ The proposed structure would respect the values and desires of the deceased person and provide a mechanism to ensure that, if practically possible, the wishes are carried out. To refuse consent to the harvest of the organs of a person who wished them to be used, is to fail to respect that person's autonomy, even if the family opposes organ collection. ${ }^{45}$

It could be argued that respecting autonomy does not require the satisfaction of the prior desires of the dead, because the dead cease to exist as autonomous beings. Consequently, self-determination after death is meaningless, because there is no self. However, this thesis proposes that sources have property interests in their bodies, so the body can be disposed of in a manner similar to other property that is subject to testamentary disposition. ${ }^{46}$

The framework proposed would respect the autonomy of the previously living person and remove decision-making from relatives. It would allow individuals to make binding, enforceable, decisions about the eventual disposition of their bodies ${ }^{47}$ and avoid decision-making by emotionally distressed relatives when a person was dying. This thesis argues that the proposed framework would result in the collection of most organs where that was the wish of the deceased and also respect those who did not wish to have their organs harvested, which is the preferred outcome in a pluralist society. ${ }^{48}$

Some commonly suggested procurement systems are:

\section{A Conscription}

Governments could legislate that all cadavers are the property of the State. Few countries have taken such an extreme step and, in those that have, there have been concerns about human rights violations, especially where the organs of criminals have been removed following execution. ${ }^{49}$ China has allowed the harvest of organs from executed prisoners since 1984 and this practice harvests 2,000 to 3,000 organs per year. ${ }^{50}$ The law of the Syrian Arab Republic permits the removal of organs from

\footnotetext{
${ }^{44}$ See chapter 8 .

${ }^{45}$ Assuming the organs are in a suitable condition to be used and that there is a suitable recipient available.

${ }^{46}$ A will is made for the purpose of making dispositions of property, to take effect on or after the testator's death. It may also appoint executors whom the testator wishes to manage the estate. During the life of the testator, it is a mere declaration of intention and may be freely revoked or altered in a prescribed manner. On death, it crystallises and takes effect according to its tenor. Wills Act (UK) 1837.

${ }^{47}$ Including the burial instructions, subject to the estate having sufficient funds.

${ }^{48}$ See chapter 8 .

49 Christian Williams "Combating the Problems of Human Rights Abuses and Inadequate Organ Supply through Presumed Donative Consent” (1994) 26 Case W Res J Int'l L 315, 323.

50 Allison Owen "Death Row Inmates or Organ Donors: China's Source of Body Organs for Medical Transplantation" (1995) J Ind Int'l and Comp L Rev 495, 496; British Transplantation Society "British Transplantation Society criticizes the alleged use of organs without consent from prisoners executed in
} 
persons whose death is a consequence of capital punishment. ${ }^{51}$ Such seizure is premised on the notion that cadavers belong to the State, or that the taking is a form of confiscation or forfeiture.

Emson argues that the right of control over the cadaver should be vested in the State, with control vested in an organisation at arms length from it. ${ }^{52}$ He states: ${ }^{53}$

The concept of the right of a person to determine before death, the disposal of their body after death, made sense only when there was no continuing use for that body; it makes neither practical nor moral sense now, when the body for which the dead person no longer has any use, is quite literally a vital resource, potential source of life for others.

However, he recognises that such a policy may be politically unattractive in light of prevailing public opposition.

Similarly, Neri argues that property rights in the body should be eliminated and courts should not be permitted to consider the issue of entitlements after death. ${ }^{54}$ She favours the concept of mandatory organ conscription, in which medical providers would harvest every cadaveric organ suitable for transplantation, without regard to any contrary wishes previously expressed by the deceased, or by relatives after death.

This approach would increase the supply of organs, but at the cost of breaching cultural and personal sensibilities and reducing trust in the medical profession. People might resist hospital treatment, because of concern that they would be given lesser treatment in order to hasten death and make their organs available. Auckland Hospital intensive care specialist, Stephen Streat, commented: ${ }^{55}$

\footnotetext{
I believe an individual's spirituality and dignity are not things the state or others have a right to subsume or demand. And this applies to your body after you're dead. People have strong attachments to people they love. This doesn't stop the moment they die. If we, in a utilitarian way, ride over that, then we are debasing something about our humanity and spirituality.
}

Few States have adopted such policies, because of a widely held view that individuals have interests in the future treatment of their cadavers, or that family members have emotional attachment to the bodies of their kin. The involvement of family is a safeguard to ensure that human rights violations do not occur, however, the family will not necessarily be aware of the wishes of the deceased, or may choose not to follow such wishes. ${ }^{56}$

\footnotetext{
the Peoples Republic of China" 19 April 2006< http://www.bts.org.uk/morenews.htm> (last accessed 4 November 2006)

51 David Price Legal and Ethical Aspects of Organ Transplantation (Cambridge University Press, Cambridge, 2000) 83.

${ }^{52} \mathrm{H}$ E Emson "It is Immoral to Require Consent for Organ Donation" (2003) 29 J med ethics 125.

${ }^{53}$ Emson, above, 128.

${ }^{54}$ Rebecca M Neri "New Organ Donations" (2002) 10 Digest 67, 71.

55 Jenny Chamberlain “To Give or Not to Give?" (March 2004) North and South Auckland 33, 38.

${ }^{56}$ See the discussion of brain death in chapter 4 and the difficulty some people have in accepting that such a person is dead.
} 
Presumed consent is based on the notion that, if structures are in place to allow for dissent and no steps have been taken, then consent can be presumed. It is assumed to increase the donation rate by collecting organs from people who have taken no steps, either because they are willing to donate or are indifferent. Erin and Harris categorised presumed consent as a "fiction" and state that "without the actual consent of the individual, there is no consent." out", such a system is, in some sense, consensual. However, presumed consent is likely to impact most on the lower socio-economic groups, who lack the knowledge or confidence to access the opt-out processes.

Presumed consent systems are diverse in their character and impact. In "strong" systems, the lack of objection of the deceased is, in itself, sufficient authorisation for organ harvest to proceed. In "weak" systems, the agreement or lack of objection of relatives is required for the limited purpose of ascertaining whether they know of any unrecorded objection by the deceased. ${ }^{58}$

It is difficult to assess the extent to which presumed consent laws solve the organ shortage as, in some countries, ${ }^{59}$ even though there are strong laws, in practice clinicians defer to the wishes of relatives. ${ }^{60}$ However, it seems such systems do increase the rates of donation, especially if combined with a highly organised and well resourced system. ${ }^{61}$

If autonomy is ethically essential, then presuming consent is wrong. The empirical basis for such a system is unclear. Is it a belief that reasonable persons do not object to the use of their organs for transplantation and so there is no objection to unconsented harvest? If not, then presumed consent disrespects autonomy. Alternatively, is it that most people would consent to donation if they took any steps, but for various reasons, such as procrastination or a reluctance to consider their own mortality, they never actually give consent? Thus, presumed consent is actually doing for them what they would have done, had they ever sufficiently overcome apathy to take any steps at all.

If empirical foundations are irrelevant, then the normative foundation may be the value of saving lives. The Report of the Conference of European Health Ministers supported this approach, stating: ${ }^{62}$

\footnotetext{
${ }^{57}$ C Erin and J Harris "Presumed Consent or Contracting Out" (1999) 25 J med ethics 365, 365 (emphasis added).

${ }^{58}$ G Wolfslast "Legal Aspects of Organ Transplantation" (1992) 11 J Heart and Lung Trans 160.

${ }^{59}$ Such as France, Spain and Poland. A Council of Europe survey in 1987 found that 21 Member States and Finland had presumed consent systems.

${ }^{60}$ David Price Legal and Ethical Aspects of Organ Transplantation (Cambridge University Press, Cambridge, 2000) 87.

${ }^{61}$ Price, above, 92. The lack of intensive care beds is a major impediment to increased organ harvest in New Zealand, together with a failure to ask for consent in every case where a person might be a donor. ${ }^{62}$ Third Report of the Conference of European Health Ministers (Paris 16-17 November 1987) Organ Transplantation: Legislative Measures in Relation to Organ Transplantation and to European Cooperation (Council of Europe, Strasbourg, 1987) 105-6.
} 
When the right to life and health of the diseased person awaiting transplantation comes into conflict with the supposed "right" of a cadaver, which is no longer a person, the right of the living recipient is certainly predominant over that of the dead donor. The interest of the community prevails over that of the individual dead body.

The British Medical Association recommended that the UKHTA include presumed consent. However, the Government decided against it ${ }^{63}$ and the Health Minister stated that full consent is the cornerstone of the new legislation because, "[o]ur bodies are not the property of the state, they are not the property of doctors or scientists or researchers." She added: ${ }^{64}$

There is no evidence that a policy of presumed consent increases the number of organs for transplantation. Evidence from Spain, which has the highest organ donation rates in the world, has shown that having a person responsible for identifying possible organ donors in hospital is the most effective way of increasing donors.

In many European countries, presumed consent is being replaced with voluntary systems ${ }^{65}$ and in North America there are opt-in policies. In New Zealand, individualism is overlaid by cultural and historical influences and, in light of the need to respect Māori cultural values, any movement toward presumed consent would necessitate prior consultation with Māori, who would be unlikely to support it. ${ }^{66}$ Consequently, it is not proposed in the HTB.

Presumed consent is not necessarily incongruous with a property construct, because the public interest overrides private title in other contexts. However, a presumed consent system would require persons wanting the property interest in their bodies to pass to their representatives to opt-out; otherwise the interest would be overridden by the interest of the state in acquiring transplantable organs. Presumed consent is, in effect, a form of nationalisation of body parts and, for the reasons discussed above in the context of conscription, it is not recommended.

\section{Required Request}

In most jurisdictions where express consent is required prior to organ removal, there are no legal requirements to approach relatives, or dying patients, to seek consent for organ removal. If the possibility of donation has not occurred to them, organs may be lost. There is no apparent objection to requesting donation, so long as this function is separated from the provision of medical care to the dying patient, to avoid the suspicion of a conflict of interests. However, if the patient or family belong to a religion or culture that that does not accept donation or believes that the body must be interred whole, such an approach might be distressing or culturally offensive. Alternatively, the relatives might be so distraught that such an approach is inappropriate.

\footnotetext{
${ }^{63}$ Matthew Tempest “'Opt-out' Organ Donations Ruled Out” (15 January 2004) The Guardian Unlimited London <http://politics.guardian.co.uk> (last accessed 4 March 2004).

${ }^{64}$ Richard Woodman "UK Rules out Presumed Consent for Organ Donation" (14 January 2004) Reuters $<\mathrm{http}: / / \mathrm{www}$. reuters.com $>$ (last accessed 21 February 2004).

${ }^{65}$ Troy R Jensen "Comment: Organ Procurement: Various Legal Systems and their Effectiveness" (2000) 22 Houst j int law 555, 573.

${ }^{66}$ Māori cultural values are considered in chapter 5.
} 
Health-care professionals are reluctant to be required to make such approaches in every case and some clinicians would object to bureaucratic intervention that intruded on their clinical discretion. In a study of deaths in New Zealand intensive care units in the year to 31 March 2000, it was found that of the 104 people who died, consent was not sought from 16 potential donors, because the doctors felt the family's circumstances made approaching them for consent inappropriate. Organs were retrieved from only 36 persons. ${ }^{67}$

By 1990, 26 states in the United States and the District of Columbia had enacted required request laws, and a further 18 had routine enquiry laws. ${ }^{68}$ Required request laws require documentation of a request and its outcome on the death certificate, whereas routine enquiry laws require that hospitals develop policies, or protocols, to ensure that families are asked to donate. These have not been highly successful, with levels of non-compliance by physicians exceeding 50 per cent in some states. ${ }^{69}$ There has not been the anticipated increase in rates of donation, with initial modest increases that tailed off after about two years.

The proposed framework would encourage prior discussion of donation and representatives would be aware of their appointment. Consequently, if an appointer was on life support, the representative would anticipate an approach and not be offended by it. If staff made the approach, there would be no need for legislated required request. Streat argues that this role should be assumed by intensivists, who should adopt a morally neutral position, as they often facilitate decision-making in other contexts, such as whether to withdraw intensive care. ${ }^{70}$

\section{Mandated Choice}

Mandated choice requires persons to specify whether or not their organs may be transplanted as a condition of receiving some benefit, such as a driver's licence. This appears to respect personal rights, as the person is free to agree or decline. However, mandated choice is in tension with autonomy, because choice is mandated. A person's autonomy is compromised if forced to choose, especially as a condition of receiving a benefit, as the decision may have been made in order to receive the benefit, rather than being genuine consent.

\section{E Preferred System}

It is impossible to devise a perfect system for acquiring organs. The current opt-in system results in an inadequate supply. If the system involves conscription, it is likely to violate individual autonomy and impact on personal rights. In New Zealand, the HTB retains the present opt-in system but, contrary to present practice, if a person consented to donation prior to death, harvesting would proceed, despite the objections

\footnotetext{
67 "Death Tests Could Ease Organ Need" (14 November 2000) The Dominion Wellington A4.

${ }^{68}$ A Gaber and others "An Assessment of the Impact of Required Request Legislation on the Availability of Cadaveric Organs for Transplantation" (1990) 22 Transplant proc 318, 318.

${ }^{69}$ V Robertson and others "Concentrated Professional Education to Implement Routine Referral Legislation Increases Organ Donation” (1998) 30 Transplant proc 214, 214.

${ }^{70}$ Stephen Streat "Clinical Review: Moral Assumptions and the Process of Organ Donation in the Intensive Care Unit” (2004) 8 Critical Care 382, 386.
} 
of relatives. So long as the consent was fully informed, this policy would respect the autonomy and rights of the previously living person and allow their rights and the needs of the recipient to trump the rights of relatives. However, as is discussed below, the HTB focuses on consent alone rather than respecting the source's right to dissent.

This thesis argues that property rights would carry greater weight, allow remedies in the event of a breach and avoid the need to make the request to relatives (other than the representative) at a distressing time. If the person wished only to express a lack of objection to donation, rather than actually consent, then the appointment could specify that certain relatives would have a power of veto, and the personal representative would be required to respect this. ${ }^{71}$

\section{COMMON LAW PERSPECTIVES ON PROPERTY IN THE DEAD BODY}

Property rights in dead bodies have been questioned since the seventeenth century, ${ }^{72}$ originating with Haynes' case in $1614 .{ }^{73}$ Haynes was indicted for the theft of four winding sheets, used in the burial of three men and a woman. It was essential for the success of the indictment to state the person with property in the sheets. It was decided that property remained with the owners at the time the bodies were wrapped in the winding sheets, because the dead body is not capable of owning property. It did not decide, as has since been claimed, that the dead body is not capable of being property.

Blackstone stated that a corpse cannot be property, but did not cite any authority. ${ }^{74}$ Sir Edward Coke stated that as "[t]he burial of the Cadaver (that is, caro data vermibus) is nullius in bonis and belongs to Ecclesiastical cognizance." 75 As the cadaver was "in the goods of no one," no property rights could exist. Similarly Roman law held "Dominus membrorum suorum nemo videtur"76 Thus, as Paul Matthews states: ${ }^{77}$

The classical writers of the common law, then, for the most part agree that there is no property in corpses, but they either cite each other or the case of a buried corpse where the question did not even arise, much less was decided.

In $R v$ Sharpe ${ }^{78}$ the defendant's mother had been buried in unconsecrated ground. When his father died, the defendant was permitted to open his mother's grave in order to bury his father there, but instead he took both bodies to be buried in a consecrated graveyard. He was convicted of unlawfully, wilfully and indecently opening a grave and removing a body. However, he was not charged with larceny, because: "Our law recognises no property in a corpse..." 79

\footnotetext{
${ }^{71}$ See the proposals in chapter 8 .

${ }^{72}$ Sir Edward Coke The Third Part of the Institutes of the Laws of England: Concerning High Treason, and Other Pleas of the Crown and Criminal Causes (W Clarke and Sons, London, 1817) 203.

${ }^{73}$ Haynes' case (1614) 12 Co Rep 113, 77 E R 1389 as discussed in Paul Matthews "Whose Body?

People as Property" (1983) 36 CLP 193, 197.

${ }^{74}$ William Blackstone Commentaries Vol 2, 429; William Blackstone Commentaries Vol 4, 236.

${ }^{75}$ Coke, above, 110

${ }^{76}$ Ulpianus, Dig 9, 2, 13 translatable as "It appears to be the case that no one is the owner of his/her own body parts."

77 Paul Matthews "Whose Body? People as Property" (1983) 36 CLP 193, 198.

${ }^{78} R$ v Sharpe (1857) Dears \& Bell 160, 163, 169 ER 959, 960.

${ }^{79} R v$ Sharpe, above, 163 Erle J.
} 
Subsequent common law cases have applied the general rule that human body parts cannot be property, ${ }^{80}$ although in England a few decisions have recognised that substances from the body such as blood and urine are property capable of being stolen. ${ }^{81}$ The persons charged by the law with the duty of interring the body have a right to the custody and possession of it until it is properly buried. ${ }^{82}$ There does not appear to be such a duty on next-of-kin. ${ }^{83}$ If there is no duty, there is no legal right to possession of the corpse.

The issue was considered in relation to an intestate death, when a dispute arose about the funeral arrangements between, on the one side, the widow, her sister and the deceased's sister and, on the other side, the chief kaumatua ${ }^{84}$ of the sub-tribe to which the deceased belonged. ${ }^{85} \mathrm{~A}$ defamation claim was brought by the kaumatua, whose actions in seizing the body were referred to in a press report as "body snatching." Hammond J stated: ${ }^{86}$

\begin{abstract}
At common law a person does not "own" his or her body. But those responsible for the estate of a deceased person have a duty to see to a proper burial according to law .... Here nobody had a common law right to Billy T's body at the relevant time. But the body was in the legal possession of the widow and those in the Muriwai house.
\end{abstract}

Hammond $\mathrm{J}$ applied $R v$ Sharpe,${ }^{87}$ but did not refer to the fact that the case related to a buried corpse and that the comments were obiter. Matthews argues that it is difficult to understand why the statement in $R v$ Sharpe $^{88}$ should also apply to an unburied corpse, in which there is a limited right to possession. ${ }^{89} \mathrm{He}$ states: "If the right of possession is only for the purposes of burial (or other lawful disposal) then the right is effectively subject to something like a trust." $" 90$

Doodeward $v$ Spence ${ }^{91}$ is authority for the proposition that once a body has undergone a process or other application of human skill, such as stuffing or embalming, it can be the subject of property. Griffith CJ stated that “... so far as it constitutes property, a human body, or a portion of a human body, is capable by law of becoming the subject of property." ${ }^{92} \mathrm{He}$ added: ${ }^{93}$

\footnotetext{
${ }^{80}$ William Boulier "Sperm, Spleens and Other Valuables: The Need to Recognise Property Rights in Human Body Parts" (1993) 23 HOFSTRA L Rev 693, 693; Williams v Williams (1882) 20 Ch D 659, 662-663; J F Clerk, W H B Lindsell and A M Armitage Clerk and Lindsell on Torts (17ed, Sweet and Maxwell, London,1995) 653, para 13-50.

${ }^{81} R v$ Rothery [1976] RTR 550, 552-553; $R v$ Welsh [1974] RTR 478, 479; $R v$ Herbert [1961] JPLGR 12, 13.

${ }^{82}$ Clerk, Lindsell and Armitage, above, 653.

${ }^{83}$ Dobson and Another v North Tyneside Health Authority and Another [1996] 4 All ER 474, 478

(CA) Butler-Sloss, Gibson, Thorpe LJJ.

${ }^{84}$ Elder or person with high status.

${ }^{85}$ Awa v Independent News Auckland Ltd [1995] 3 NZLR 701 (HC) Hammond J.

${ }^{86}$ Awa v Independent News Auckland Ltd, above, 705.

${ }^{87} R v$ Sharpe (1857) Dears \& Bell 160, 169 ER 959.

${ }^{88} R$ v Sharpe, above.

${ }^{89}$ Paul Matthews "Whose Body? People as Property" (1983) 36 CLP 193, 211.

${ }^{90}$ Matthews, above, 214.

${ }^{91}$ Doodeward v Spence (1908) 6 CLR 406, 414 (HCA) Griffith CJ, Barton, Higgins JJ.

${ }^{92}$ Doodeward v Spence, above, 414.

${ }^{93}$ Doodeward v Spence, above, 414.
} 
When a person has by the lawful exercise of work or skill so dealt with a human body or part of a human body in his lawful possession that it has acquired some attributes differentiating it from a mere corpse awaiting burial, he acquires a right to retain possession of it, at least as against any person not entitled to have it delivered to him for the purpose of burial...

Barton J stated that an unburied corpse was not the subject of property, while Higgins $J$ stated that no one could have property in another human being, alive or dead. Barton $\mathrm{J}$ and Higgins $\mathrm{J}$ differed in the result, because Barton $\mathrm{J}$ held that a stillborn foetus did not constitute an unburied corpse within "the general rule."

In Dobson and another $v$ North Tyneside Health Authority and another, ${ }^{95}$ the next of kin of a deceased woman wanted the hospital to produce the brain, which had been removed at post-mortem, but not sectioned for histology. The hospital could not do so. The Court held that while it was "arguable" that a body or body part that had been embalmed or fixed might become property, a brain held in storage, but later lost or destroyed, was not. The Court did not wish to impose a duty on hospitals to retain tissue removed at post-mortem just in case it could be required for any future litigation. The brain was lawfully removed for the post-mortem and the obligation to retain the material continued only so long as the coroner required. The plaintiffs could not establish a right of possession at the time the brain was disposed of because although the executor has a limited right to possession of the cadaver, the next-of-kin does not.

Similarly, in $A B v$ Leeds Teaching Hospital NHS Trust, ${ }^{96}$ Gage J held that the rights following a post-mortem are unclear, but favoured the view that pathologists are entitled to possess removed body parts, because the removal was lawful and parents had no right to possession of them once their children were buried. The preservation of the parts fell within the Doodeward ${ }^{97}$ exception. However, Gage J held that if the parents: ${ }^{98}$

...when consenting to a post-mortem specifically asked for the return of an organ I can see that in certain circumstances ..... a cause of action based on conversion exists....But in the absence of such a cause of action in respect of the body of a deceased person being recognised by an English Court I am not prepared to hold that one does exist.

Gage $\mathrm{J}$ further stated that, should the doctor fail to pass such a condition on to the pathologist, a claim for negligence might arise. ${ }^{99}$

It is not the application of work and skill, in itself, that creates the ownership rights over the tissue, but the creation of a new object. If tissue is donated on a permanent basis, the researcher may obtain lawful possession and this may provide the opportunity for the creation of proprietorship rights if the item has genuinely

\footnotetext{
${ }^{94}$ Doodeward $v$ Spence, above, 416. See the discussion on personhood in chapter 4.

${ }^{95}$ Dobson and Another v North Tyneside Health Authority and Another [1996] 4 All ER 474, (CA) Butler-Sloss, Gibson, Thorpe LJJ.

${ }_{96}^{96}$ A v Leeds Teaching Hospital NHS Trust [2004] EWHC 644, para 156 (QB) Gage J.

${ }^{97}$ Doodeward $v$ Spence, above.

${ }^{98}$ AB v Leeds Teaching Hospital NHS Trust, above, para 161.

${ }^{99}$ AB v Leeds Teaching Hospital NHS Trust, above, para 161.
} 
changed its identity. In Doodeward, the application of skill amounted merely to the preservation of the two-headed foetus. However, it was stated in Dobson that the mere preservation of pathological or anatomical specimens by fixing would not be sufficient to amount to the required change in identity, and that preservation was not on a par with stuffing or embalming a corpse. ${ }^{100}$

The Royal College of Pathologists issued a Consensus Statement with the Institute of Biomedical Science stating: ${ }^{101}$

Pathologists, in the course of ordinary medical practice, substantially transform specimens from their original state. The durable materials thus produced (slides and blocks) can fairly be claimed as the property of the entity which produced them.

Such material has not been altered to become something other than preserved human tissues. However, the creation of a cell line from human cells is more clearly a change that could create property rights for the creator. Cell lines are routinely sold by providers of laboratory supplies and are believed to be outside the prohibitions on selling human tissue that apply in many countries. ${ }^{102}$

Preservation of bodies arose in another context in $R v$ Kelly, $R v$ Lindsay, ${ }^{103}$ where body parts were "stolen" from the Royal College of Surgeons in London, to be used for artistic purposes. On appeal, it was argued that the trial judge had been wrong to say that these preserved body parts were property in the Doodewood sense. The Royal College might have been custodian of the parts, but since they were not property it could not own them, so they could not be stolen. Rose LJ stated that the common law does not stand still, so the courts might, in the future, hold that body parts are capable of being property, even without the acquisition of different attributes, if they have a use or significance beyond their mere existence. He stated, as examples, where they are intended for use in an organ transplant operation, for the extraction of DNA, or as an exhibit in a trial. ${ }^{104}$

The present position seems to be that the dead body is presumed to have no value. This may have been so in the eighteenth century, but clearly is not so today. As stated by Cowan J: ${ }^{105}$

Human remains can have significant commercial value, even though they are not typically bought and sold like other goods. Although remains which are used for these medical and scientific purposes are usually donated, rather than bought and sold, this does not negate their potential commercial value.

Furthermore, when misappropriation is claimed, value per se is not relevant. In Colavito $v$ New York Organ Donor Network Inc ${ }^{106}$ the New York Court of Appeals

\footnotetext{
${ }^{100}$ Dobson, above, 479G.

${ }^{101}$ Royal College of Pathologists Consensus Statement of Recommended Policies for Uses of Human Tissue in Research Education and Quality Control (Royal College of Pathologists, London, 1999) 12.

${ }^{102}$ See the discussion in chapter 3 of Moore $v$ Regents of the University of California (1990) 793 P 2d 479, 479-97 (Sup Ct Cal) Panelli J, Lucas C J, Eagleson, Arabian and Kennard JJ concurring, Broussard J (concurring and dissenting), Mosk J (dissenting).

${ }^{103} R$ v Kelly, $R$ v Lindsay [1999] Q B 621 (CA) Rose LJ, Ognall, Sullivan JJ.

${ }^{104} R v$ Kelly, $R v$ Lindsay, above, $631 \mathrm{C}$ Rose $\mathrm{J}$.

${ }^{105}$ Onyeanusi v Pan Am (1992) 952 F 2d 788, 792 (3d Cir).
} 
considered the misappropriation of a human kidney that the deceased's widow had agreed could be harvested for the purpose of transplantation into the plaintiff. Regarding conversion, Sack J stated that: "there is by no means a modern consensus that body parts are excluded from conversion actions at common law." ${ }^{107}$ He held that the quasi-property cases relating to emotional harm caused by misuse of a corpse were inapplicable, ${ }^{108}$ because a person who fails to receive a donated organ is not suing for control over a body. He stated that rather, a prospective recipient would sue for the loss of a functioning organ, and added: ${ }^{109}$

Plaintiffs such as Colavito are not using the term "property" as a legal fiction upon which to base a claim for emotional harm. They have-or assert they have - a practical use for the organ, not a sentimental one.

Although New York public policy prohibits the sale of organs, Sack J held that this does not necessarily imply that policy also intends that no one can acquire a property right in them. He stated: ${ }^{110}$

It does not follow from a law that forbids the sale of a functioning human kidney, that a third party may with impunity take the organ against the express wishes of a potential donor and potential donee.

He added that it is arguable that both the source's widow and the recipient had enforceable rights to have their wishes as to the donation of the kidneys honoured. In deciding the recipient had such rights, he referred to privity of contract principles. ${ }^{111}$ This suggests that the widow had a property right in her deceased husband's kidneys that she had agreed to transfer to the recipient.

Property was also considered in an Australian case in which the plaintiff wished to establish whether the deceased was her father through DNA tests of body specimens taken from him during surgery. ${ }^{112}$ The legislation provided for the making of orders with respect to property. Master Sanderson considered the case law and quoted with approval the following passage from Palmer and McKendrick: ${ }^{113}$

Proprietary actions such as theft and conversion are clearly appropriate to ensure that the terms of a tissue bailment are respected. In the Australian context, the terms of bailment would limit the purposes to which donated tissue could be put to the purposes specified in human tissue legislation. Similar terms, it is submitted, would also be implied at common law, where tissue is donated for transplantation or scientific research. In both Australia and the UK, proprietary remedies are necessary since no specific legislative offences exist for the maltreatment or destruction of validly donated tissue. To apply the "no property" rule here would be to open up a cavernous regulatory vacuum which will rapidly widen as

\footnotetext{
${ }^{106}$ Colavito v New York Organ Donor Network Inc (2006) 438 F 3d 214 (US App) Sack J.

${ }^{107}$ Colavito $v$ New York Organ Donor Network Inc, above, 27.

${ }^{108}$ Quasi-property is discussed below.

${ }^{109}$ Colavito v New York Organ Donor Network Inc, above, 30-31.

${ }^{110}$ Colavito $v$ New York Organ Donor Network Inc, above, 33.

111 The court stated that a third party can enforce an agreement for their benefit even though there is no consideration from, nor privity with, nor obligation to, the third person.

${ }^{112}$ Roche $v$ Douglas as administrator of the Estate of Edward John Hamilton Rowan (Dec) [2000] WASC 146 (7 June 2000) Civ 2115 (WASC) Master Sanderson.

${ }^{113}$ Norman Palmer and Ewan McKendrick (eds) Interests in Goods (Lloyd's of London Press, London, 1998) 25.
} 
umbilical cords, frozen blood vessels, bones, joints and freeze-dried nerves (to name just a few) join blood and blood products as items of storage in tissue banks.

The authors also concluded that tissue removed during medical procedures should be regarded as gifted to the relevant hospital in the absence of specific agreement which, they assert, is only possible if the tissue has the status of property. Master Sanderson also referred to a 1977 Australian Law Reform Commission Report, which stated that such tissue had no status at law. The Master commented that the world has moved on since 1977 and, in light of the need to apply the principles of law in line with reason and good sense, decided that it is proper to hold that human tissue is property. He commented: ${ }^{114}$

\begin{abstract}
In the wider sense it defies reason to not regard tissue samples as property. Such samples have a real physical presence. They exist and will continue to exist until some step is taken to effect destruction. There is no purpose to be served in ignoring physical reality. To deny that tissue samples are property, in contrast to the paraffin in which the samples are kept or the jar, in which both the paraffin and the samples are stored, would be in my view to create a legal fiction.
\end{abstract}

However, he declined to determine who holds the proprietary interests in the tissue. This is a fundamental issue, if the human source is to retain rights. ${ }^{115}$ Although this case could be seen as confined to the particular facts, the need for the law to adapt to rapid change in this area is clearly enunciated.

\title{
A
}

\section{Effect of Framework on Common Law Position}

This thesis suggests that the proposed framework should not differentiate between organs and samples. The public policy pressures are unclear as enforceable property rights may have the effect of deterring doctors and hospitals that need to act urgently to preserve organs. ${ }^{116}$ However, as was suggested in Calovito, ${ }^{117}$ if there are no such rights, with legal remedies to enforce them, donors or their families may refuse to donate.

The present enforceable rights with respect to corpses, such as the rights to possess for the purposes of conducting a post-mortem, or for disposal of the body, are possessory rights, rather than proprietary rights of the type normally involved in property. A conceptual problem is that in other contexts where possessory rights exist, such as a bailment, some other person will have title in the goods. If the executors have extended possessory rights in the corpse, these will exist in the absence of property interests, resulting in the corpse being res nullius.

\footnotetext{
${ }^{114}$ Roche $v$ Douglas as administrator of the Estate of Edward John Hamilton Rowan (Dec), above, para 24. See also the discussion of $H v G$ (14 May 1999) High Court Auckland M1868/98 Salmon J discussed in chapter 3 .

${ }^{115}$ Moore v Regents of the University of California (1990) 793 P 2d 479 (Cal SC) directly considers whether a source can assert a property right over removed samples. See the discussion in chapter 3.

${ }^{116}$ Note the suggestion in chapter 8 that if such parties act in good faith they will be immune from liability.

${ }^{117}$ Colavito v New York Organ Donor Network Inc, above, 27 .
} 
There are conceptual difficulties in attempting to argue that that the deceased person has property rights in the corpse, because a non-existent entity cannot be said to own anything. As stated by Price: ${ }^{118}$

The former person's autonomy therefore receives due consideration and respect through personal rights rather than property rights subsisting after death. Thus, if a body could potentially become property at death, any ownership rights would have to be in the hands of third parties.

Where administration of the estate of a deceased person has been granted, the administrator has power to bring any action in respect of the estate comprised in or affected by the grant. ${ }^{119}$ The framework suggests that title in the corpse arises briefly prior to death and at death passes to the representative, who may be the administrator of the estate or may be a person appointed for this task alone. The representative will have title in the corpse, arising from the appointment, which will not require a grant of administration to be effective. ${ }^{120}$ The representative will be able authorise possessory rights of others, such as the doctor or hospital carrying out the organ transplantation, or transfer title to researchers in accordance with the instructions of the deceased. If the deceased instructed that conditions be imposed, such as the type of research or the time for which the body parts could be retained and utilised, the representative would permit possession and use by the researchers, subject to these conditions.

Institutions carrying out transplantation or research would obtain possessory rights to the materials, subject to the terms of the bailment as established by the representative, who could bring an action in conversion if the cadaver was misused. The remedy would be damages and/or an order for the return of the biological material, if it was being used in research. The estate would have a right to claim the benefits from a patent, if the materials were improperly acquired. ${ }^{121}$ Alternatively, if so instructed by the deceased, the representative could transfer the cadaver unconditionally. In any event, once organs were transplanted into the body of a recipient, they would become part of that person's body and no longer subject to claims for recovery by the representative.

Rapid identification of the representative would be vital, as delay is likely to be fatal to any potential organ transplantation. ${ }^{122}$ The Human Tissue Bill (HTB) proposes a complex consent structure, plus an organ donation register, ${ }^{123}$ but this thesis proposes a similar structure to that presently applying to enduring powers of attorney, with a copy of the appointment retained by appointer and representative. ${ }^{124}$

\footnotetext{
${ }^{118}$ David Price "From Cosmos and Damian to Van Velzen: The Human Tissue Saga Continues" (2003) 11 Med L Rev 1, 33 (emphasis in the original).

${ }^{119}$ Administration Act 1969, s23.

${ }^{120}$ To require such a grant would result in delay which would render the organs unusable.

${ }^{121}$ See the discussion in chapter 7.

${ }^{122}$ See the discussion in chapter 8 .

${ }^{123}$ A person could consent before death, or appoint a nominee, or make an entry on the register. See the discussion later in this chapter.

${ }^{124}$ Protection of Personal and Property Rights Act 1988, Schedule 3. However the Protection of Personal and Property Rights Amendment Bill proposes strengthening witnessing requirements so that the donor's signature must be witnessed by a lawyer or authorised officer of a trustee corporation engaged independently of the attorney and requiring certification by the witness at the time the
} 
Representatives would then be able to act immediately they became aware that the source was in intensive care and unlikely to survive. As with an enduring power of attorney, ${ }^{125}$ the source could authorise the representative to act generally, in relation to the whole or a specified part of the property right over the body, or limit the power to act to specified things, and such authorisation could be given subject to conditions and restrictions. ${ }^{126}$

\section{QUASI-PROPERTY}

In Britain, matters relating to the interment of corpses were dealt with by the ecclesiastical courts, until jurisdiction was gradually transferred to the common law courts. However, in the United States, there were no ecclesiastical courts and so cadavers and body parts fell within the common law, which did not recognise property rights in them. ${ }^{127}$ The no-property tradition needed to be reconciled with the need to ensure that corpses were given proper disposition and due regard. ${ }^{128}$ Consequently, American courts began to move closer to a property based approach, by adopting a quasi-property standard. It was held that the no-property rule was unsound in light of the rights of the next of kin with regard to burial. ${ }^{129}$

A quasi-property right in a cadaver refers to the rights of the family to claim the body for burial purposes, but not for any other reason. As stated in Bogert $v$ City of Indianapolis: ${ }^{130}$

We lay down the proposition, that the bodies of the dead belong to the surviving relatives, in the order of inheritance, as property, and that they have the right to dispose of them as such, within restrictions analogous to those by which the disposition of other property may be regulated.

This concept of quasi-property is a consequence of the inherent ambiguity of the term "property". It results in the body being the subject of property-based causes of action or jurisdiction, without allowing any proprietary rights in it. Quasi-property does not amount to a true right of ownership and there is no right to transfer or use the body, other than for the prescribed purpose, such as burial. ${ }^{131}$

Quasi-property is an attempt to balance two competing interests, by refusing to fully recognise a property right in a dead body, while at the same time ensuring proper respect for the dead. However, recent cases have been less clear. In Brotherton $v$ Cleveland, ${ }^{132}$ the Court of Appeals considered a statute that permitted the coroner to remove the corneas, so long as he knew of no objection from the decedent's spouse or

enduring power of attorney is created that certain specified matters have been explained to the donor before the donor signed it.

${ }^{125}$ Protection of Personal and Property Rights Act 1988, s97 (1) and (2).

${ }^{126}$ See the legislative proposals in chapter 8.

${ }^{127}$ William Boulier "Sperm, Spleens and Other Valuables: The Need to Recognise Property Rights in Human Body Parts” (1993) 23 HOFSTRA L Rev 693, 707.

${ }^{128}$ Boulier, above, 707.

${ }^{129}$ Renigan $v$ Wright (1890) 25 NE 822, 824-825 (Ind).

${ }^{130}$ Bogert $v$ City of Indianapolis (1859) 13 Ind 134, 138.

131 The United States Congress, Office of Technology Assessment, New Developments in Biotechnology: Ownership of Human Tissues and Cells - Special Report (US Government Printing Office, Washington DC, 1987) 72.

${ }^{132}$ Brotherton v Cleveland (1991) 923 F 2d 477, 482 ( $6^{\text {th }}$ Cir $)$. 
the person authorised to dispose of the body. The widow advised the hospital of her objection, but this was not conveyed to the coroner, who removed the corneas. It was held that the removal amounted to a deprivation of the constitutionally protected due process rights of the spouse under the United States Constitution, as she had a "legitimate claim of entitlement" in the body.

This was followed in Michigan in Whaley $v$ County of Tuscola. ${ }^{133}$ It was held that the next of kin had a constitutionally protected property interest in a deceased relative's body, including the eyes, as such rights "are the heart and soul of the common law understanding of "property'."134 This decision has been criticised because it disregards the historical reason for a "quasi-property" right, which was to prevent a property interest in dead bodies. ${ }^{135}$

Constitutional challenges to presumed consent laws have been unsuccessful ${ }^{136}$ because it has not been accepted that there is a privacy right in the human body that extends beyond death and the quasi-property rights, where accepted, do not amount to constitutional protection. In Arnaud v Odom, ${ }^{137}$ a coroner was unsure of the effect of a drop from a certain height on the skull of an infant. He performed experiments on the corpses of two other infants, by dropping them on their heads from different heights. The court held that such experiments, while abhorrent, did not support a claim for interference in a property right in a corpse. ${ }^{138}$ It was accepted that there were quasi-property rights in corpses, but they did not amount to the constitutional protection guaranteed by the due process clause.

The major distinction between a property right and a quasi-property right is the basis in which the law is grounded. The quasi-property right does not relate to the injury to the dead body, but rather whether the improper actions cause emotional or physical pain and suffering to the surviving family members. ${ }^{139}$ Even if the dead body is damaged in some way, there will be no redress if the parties were not demonstrably affected by it. Thus, as was discussed in Colavito, ${ }^{140}$ quasi-property is not an adequate solution to the body parts conundrum, because of the need to address the ongoing control of the retention and use of body parts and the sharing of profits arising from biotechnological inventions, rather than just the harm to relatives. ${ }^{141}$

\section{SHOULD PROPERTY IN A DEAD BODY BE RECOGNISED?}

\section{A Societal Changes}

\footnotetext{
${ }^{133}$ Whaley $v$ County of Tuscola (1995) 58 F 3d 1111, (6 ${ }^{\text {th }}$ Cir), cert denied (1995)116 S Ct 476.

${ }^{134}$ Whaley $v$ County of Tuscola, above, 1114.

135 Thomas L O’Carroll “Over My Dead Body: Recognizing Property Rights in Corpses” (1996) 29 HOSPLW 238, 238.

${ }^{136}$ Tillman v Detroit Receiving Hospital (1985) 360 NW 2d 275 (Mitch Ct App); Georgia Lions Eye Bank Inc v Lavant (1985) 335 SE 2d 127 (Ga); State v Powell (1986) 497 So 2d 1188 (Fla).

${ }^{137}$ Arnaud v Odom (1989) 870 F 2d 304 ( $5^{\text {th }}$ Cir).

${ }^{138}$ In the Unites States, the constitutionality of a statute may be contested on the basis that property rights have been infringed. If private property is taken for public use, compensation is required to be paid under the "Takings Clause" in the Fifth Amendment.

${ }_{139}$ Culpepper v Pearl St Building (1994) 877 P 2d 877, 880 (Colo).

${ }^{140}$ Colavito $v$ New York Organ Donor Network Inc (2006) 438 F 3d 214 (US App) Sack J. See discussion above.

${ }^{141}$ See the discussion in chapters 3 and 7.
} 
On the few occasions the courts dealt with body parts, they only used property terminology as a last resort. Cadavers were treated differently from other inanimate objects, because medical science was insufficiently advanced to remove organs from the living, and there were compelling public health reasons to prevent access to dead bodies, other than for disposal. There were no medical reasons for such access, except for educational purposes.

Society has changed markedly since the times of Coke and Blackstone. The ecclesiastical influence has disappeared, and New Zealand society is multi-cultural and mainly secular. Handling human tissue now has minimal health and safety risks and it can be used in many previously inconceivable ways. The societal pressures that previously pointed away from lawfully possessing and using human tissue from cadavers now point towards it. As stated by Matthews: ${ }^{142}$

The non-property solutions of yesterday are inadequate to the task of today. That does not mean that a property analysis is the only - or even the best - way to deal with that task, but it at least invites the inquiry. If the answer is favourable, property law could be developed to the right level.

\section{B Conflicting Interests}

The common law essentially sees property as a negative concept, in that it confers a right to exclude others. ${ }^{143}$ As stated by Price: ${ }^{144}$

Whilst property rights may entitle one to take action, typically for damages, against specific individuals, property rights are rights against the world and permit the potential continuing exercise of control with respect to the items concerned.

Living persons have continuing interests in their tissue, ${ }^{145}$ including being able to control the uses to which such tissue may be put. At present, the family has an interest in ensuring the proper disposal of the body and the executor has a duty in this regard, but neither owns it. This does not provide an independent basis for donating, utilising or selling the cadaver. Consequently, in the absence of specific legislative provision, there appears to be little justification for allowing the family to consent in the absence of any prior consent by the deceased. However, if a cadaver is property, the representative would have ownership rights, but would be required to carry out the deceased's instructions. Consequently, the interests of the previously living person would trump those of relatives.

The arguments against this include the concern that if doctors harvest organs in the face of family opposition, there is the potential for distressing altercations with, or between, family members, in very highly charged emotional circumstances. New Zealand is a multi-cultural society, and different cultural values may be reflected within one family, resulting in potential conflicts about organ donation, or even in the type of funeral that is appropriate.

\footnotetext{
${ }^{142}$ Paul Matthews “The Man of Property” (1995) Med L Rev 251, 256.

${ }^{143}$ See chapter 1.

${ }^{144}$ David Price "From Cosmos and Damian to Van Velzen: The Human Tissue Saga Continues" (2003)

11 Med L Rev 1, 26 (emphasis in the original).

${ }^{145}$ See chapter 3 for interests in living bodies.
} 
Publicity arising from disputes might to give rise to implications of "body snatching", leading to a loss of trust in the medical profession and, potentially, an increased number of people deciding not to donate. Further, even if family objections are overridden, in most cases it is necessary that the family co-operates by providing the donor's medical and social history, or the organs may not be able to be used. ${ }^{146}$

Despite these arguments, this thesis favours decision-making by a representative because it would ensure compliance with the wishes of the deceased.

\section{Retention of Tissue Samples}

Different values are commonly given to whole organs than to tissue samples. ${ }^{147}$ There is an emotional distinction and the purpose of retention is different. As microscopic examination of tissues is an integral part of an autopsy, pathologists argue that consent to autopsy includes the retention of blocks of tissue preserved in paraffin for the preparation of microscopic slides and microscopic diagnosis. Removal of organs from bodily cavities is also an essential part of an autopsy. Normally, these are replaced in the body cavity and retention may not be justified. However, sometimes retention is necessary for diagnostic purposes. For example, the brain may have to be fixed in formalin for several weeks before it can be properly examined. ${ }^{148}$ If the brain is to be reunited with the body once the examination is complete, the funeral would need to be postponed for several weeks, which is likely to be distressing to families and culturally unacceptable to Māori.

Since the early 1990s, if organs are retained for further examination, the nextof-kin are informed and advised of the likely delay. They then have the choice of leaving the body in the mortuary until the retained organs could be replaced, or collecting it for the funeral and dealing with the retained organ later. ${ }^{149}$ However, the Greenlane Hospital heart retentions demonstrate that these processes were not always followed.

\section{Respect}

Some people perceive a link between respecting dead bodies and respecting living persons, in that treatment of dead bodies as "spare parts" might lead to deterioration of our treatment of each other during life, because of adverse social learning. Although the learning effects from the symbolism of social practices are

\footnotetext{
${ }^{146}$ The Human Tissue Bill, clause 86 permits disclosure of health information by health authorities without consent in such circumstances.

${ }^{147}$ The Auckland District Health Board Body Parts Tissues and Substances Review Panel defined a body part as "a solid discrete mass of tissue- limbs, organs or part of the body composed of more than one tissue that forms a structural unit responsible for a particular function." Tissue was defined as "a collection of cells specialised to perform a particular function." Substances were defined as "any free flowing liquid/matter produced by the body or as a result of any body function associated with physiology." Auckland District Health Board, above, 18.

${ }_{148}$ J K Mason and G T Laurie "Consent or Property? Dealing with the Body and its Parts in the Shadow of Bristol and Alder Hey” (2001) 64 MLR 710, 712.

${ }^{149}$ Auckland District Health Board, above, 28.
} 
empirically uncertain, they may be important for the development of societal norms of mutual aid and respect. ${ }^{150}$

An alternative argument is that maintaining respect for the dead by preserving the bodily integrity of cadavers has little effect in maintaining respect for the living. From this viewpoint, respect for the dead relates to the intangible, rather than physical aspects, of the former person. Thus, it neither shows disrespect for the dead nor discounts the value of their lives if their bodies are used to preserve life in others.

Emotional attachment to the dead exists in most cultures, as is demonstrated by burial rituals. ${ }^{151}$ The families involved in the unconsented retentions at Greenlane hospital did not dispute that the retained hearts were used for the benefit of other children, through improvements in surgical techniques. Despite this, many stated that the retention was unacceptable and disrespected their deceased child. Some stated that they might have consented, if asked. This suggests that even though the alleviation of suffering is valued, it must be weighed along with other values. A system of organ procurement that disrespects these values would be socially and politically unacceptable. ${ }^{152}$ An advantage of the proposed framework is that it is sufficiently flexible to allow respect for the wide variety of viewpoints in a pluralistic society. ${ }^{153}$

\section{PART II}

This Part will consider the present legislation and then compare the provisions of the UKHTA with the Human Tissue Bill (HTB), to assess whether the aims of this thesis have been achieved by either.

\section{PRESENT FRAMEWORK}

The present law relating to body parts is derived from the common law, the Human Tissue Act 1964 (HTA) ${ }^{154}$ the Coroners Act 1988 and the Coroners Act 2006, which apply to cadavers and the Code of Health and Disability Services Consumers' Rights (the Code) which applies to living persons. ${ }^{155}$

The HTA applies if tissues are taken from a dead body for any reason other than to determine the cause of death. Section 3 relates to the removal of human body parts for therapeutic purposes, medical education, or research. It does not apply to the use of the whole body, as it refers to the removal from the body of any part; thus, whole bodies fall within the common law. The HTA emphasises consent, but does not provide for property rights in a corpse or parts of it. ${ }^{156}$ The Coroners Act requires the coroner's consent for the removal of organs, if an inquest or post-mortem is required.

The HTA provides:

\footnotetext{
${ }^{150}$ Ruth F Chadwick "Corpses, Recycling and Therapeutic Purposes" in Robert Lee and Derek Morgan (eds) Death Rites: Law and Ethics at the End of Life (Routledge, New York, 1996) 64.

${ }^{151}$ See the discussion of the Māori world view in chapter 5.

${ }^{152}$ As discussed below, the Human Tissue Bill provides a complex consent regime, but inadequate provision for the source to veto the use of the cadaver.

${ }^{153}$ See the proposed framework in chapter 8.

154 The Human Tissue Bill will repeal the HTA.

${ }^{155}$ Criminal offences also apply: see Crimes Act 1961 s 150 Misconduct in respect of human remains.

${ }^{156}$ Human Tissue Act 1964, s 3. Possessory rights are some of the "strands" of property.
} 
- $\quad$ Organs may be removed for therapeutic use if the donor has made a specific request that his or her body, or a specific part of it, be so used. This may be in writing, or oral in the presence of two witnesses if during the donor's last illness;

- $\quad$ The person lawfully in possession of the body may authorise the removal of organs, according to the request;

- The person lawfully in possession of the body is not required to act on the request. In practice, this discretion means donation does not occur if opposed by the immediate family; ${ }^{157}$

- If no request has been made, the person lawfully in possession of the body may authorise removal of the organs for therapeutic purposes if, after such reasonable enquiry as may be practicable, that person has no reason to believe that the deceased had expressed an objection to such use, or that the surviving spouse or relatives so object. ${ }^{158}$

If authority has been given in these circumstances, both the removal and transplantation are lawful, provided that they are performed by a registered medical practitioner, ${ }^{159}$ who must be satisfied by a personal examination of the body that life is extinct. ${ }^{160}$

Section 2 provides that, without limiting the rights, powers or duties of any person entitled under any rule of law to the possession of any body, for the purposes of the Act, the Medical Superintendent or other medical officer in charge of any hospital, or Superintendent of any penal institution is deemed to be lawfully in possession of any body lying in the relevant institution.

The hospital's right to possession cannot limit the relatives' or executor's rights under any rule of law. Consequently, if a relative or executor claims that possessory right, they have the power to authorise or refuse removal and transplantation of organs. The hospital can only act in the absence of such right being asserted. However, a person entrusted with a body only for the purpose of burial or cremation cannot give the authority for the removal of organs. ${ }^{161}$

The Code of Practice for Transplantation of Cadaveric Organs states that, if the deceased has expressed a wish, in accordance with the Act, that the relevant parts of the body may be used after their death for therapeutic purposes, there is no legal requirement to establish lack of objection on the part of the relatives. ${ }^{162}$ It does recognise the reluctance of medical professionals to harvest organs in the face of objections by relatives, by providing that, in such circumstances, the person lawfully in possession of the body may decline to authorise the removal. ${ }^{163}$ This may also have

\footnotetext{
${ }^{157}$ Kidney Foundation of New Zealand The Gift of Life (Kidney Foundation of New Zealand, Wellington, 1995) 3.

${ }^{158}$ Human Tissue Act 1964, s 3(2).

${ }^{159}$ Human Tissue Act 1964, ss 2(1), 3(3) and 3(4).

${ }^{160}$ Human Tissue Act 1964, s 3(4).

${ }^{161}$ Human Tissue Act 1964, s 3(6).

162 Department of Health A Code of Practice for Transplantation of Cadaveric Organs (Department of Health, Wellington, 1987) 2.

${ }^{163}$ Department of Health, above, 2.
} 
been acknowledgment of the common law rights of relatives over the remains of family members. Lamb has argued there is an inconsistency in that "if we uphold the right not to donate, as a right which cannot be vetoed, then the right to donate without veto should also exist." 164

Approximately 43 per cent of drivers' licence holders have indicated that they wish to be donors. ${ }^{165}$ Many people believe that the notations on their licences are binding, although they are inadequate for the purposes of the HTA. However, notation provides an indication of the person's wishes at the time the application was made. The form states that, in the event of the licence holder's death, family will be asked for their agreement to the donation of organs even if the "yes" box has been ticked. It does not allow the person to indicate which organs they might wish to donate, nor does it provide information about the processes involved, such as brain death. It does not advise how to revoke the notation, should the decision change.

Stating a preference at a given time may be an imperfect index of the person's preferences, or their intensity. When a person applies for a driver's licence, there is generally no perceived immediacy to a question about willingness to be an organ donor. Alternatively, it could be argued that decision making in the face of an immediate crisis is less likely to be reflective decision making, because of the immediate demands of the situation. There is no ideal time for such consent - reality may always be too far, or too near.

Neither the relatives, nor any other person lawfully in possession of the body, have any "right of consent" to the use of a dead body under the HTA. Consent is only relevant in that it is implied within the expressed wish of the deceased that the body be used for medical or scientific purposes. In its absence, no one else can actively consent. However, the person lawfully in possession of the body can authorise the use of the body, provided that, after having made such reasonable inquiry as may be practicable, there is no reason to believe that the deceased had expressed any objection to organ removal, nor that the surviving spouse or relative objects to the body being so dealt with. Thus, theoretically, consent given by those in possession of the body does not remove the potential veto through dissent that any relative might express.

Many people believe that the preferred approach to organ donation is for the individual to decide the issue prior to death. Only 14 per cent of respondents in a survey of more than 1,000 adults in the United States believed that the issue should be decided by family members, ${ }^{166}$ and only about a half of those wishing to donate had told their family. ${ }^{167}$

\footnotetext{
${ }^{164}$ David Lamb Organ Transplants and Ethics (Routledge, London, 1990) 145.

${ }^{165}$ Ministry of Health Review of the Regulation of Human Tissue and Tissue-based Therapies (Ministry of Health, Wellington, 2004) $64<$ http://www.moh.govt.nz> (last accessed 23 April 2004).

${ }^{166}$ A Spital "Mandated Choice: A Plan to Increase Public Commitment to Organ Donation" (1995) 273 JAMA 504, 505.

${ }^{167}$ US Department of Health and Human Services "Clinton Administration Launches National Organ and Tissue Donation Initiative” Press Release (15 December 1997)

$<$ http://www.hhs.gov/news/press/1997pres/971215a.html > (last accessed 12 April 2005).
} 
The Body Parts Tissues and Substances Review Panel concluded: ${ }^{168}$

The Human Tissue Act recognises the deceased's right to consent to tissue or organs being used after death, however in practice clinicians will not do so against the express objection of family members. The panel acknowledges that this is a difficult issue. The majority consider that the prior informed consent of the deceased person should prevail and be respected.

This thesis supports this view, as the major weakness of the current organ donation system is that far fewer organs are available than are needed. ${ }^{169}$ Difficulties with the HTA include:

- defining the concept of the "person lawfully in possession of the body";

- uncertainty about the legality of common procedures, such as preserving organs for transplant by way of the insertion of a catheter into the femoral artery and the injection of cooling solution after death. Although the HTA permits the use of the body for therapeutic purposes, it presupposes the removal of the relevant parts for such purposes;

- defining who is a "relative";

- interpreting the phrase "such reasonable enquiry as may be practical", to ascertain objections to organ harvest. Skegg has suggested that generally all that is required is to enquire of "either the spouse or a close relative whether he or she has reason to believe that the deceased had expressed an objection, or whether some other person whose objection is relevant objects"; ${ }^{170}$ and

- lack of any provisions providing for sanctions in the event of a breach.

\section{COMPARISON BETWEEN THE UNITED KINGDOM HUMAN TISSUE ACT AND THE HUMAN TISSUE BILL}

Commentators have expressed concerns about the low rate of organ donation in New Zealand and dissatisfaction with the HTA. Consequently, the Ministry of Health undertook public consultation during 2004, leading to the introduction of the Human Tissue Bill (HTB) in November 2006. The Bill attempts to address the concerns, but this thesis asserts that the processes it establishes are unsatisfactory, particularly with regard to the consent regime.

The UKHTA covers all human tissue, whereas the HTB relates to body parts from the dead, trading in tissue, export and import, and use for non-therapeutic purposes. The collection and use of tissue from the living will remain within the Code and the common law. An exception is that the Bill covers analysis of tissue from the

\footnotetext{
${ }^{168}$ Auckland District Health Board Body Parts Tissue and Substances Review Panel Report (Auckland District Health Board, Auckland, 2002) 22.

${ }^{169}$ During 2005, there were 29 deceased donors and no non heart beating donors. Organ Donation in New Zealand Organ and Tissue Donation and Transplantation in New Zealand: 2005 Report 6 $<$ www.donor.co.nz> (last accessed 4 October 2006).

${ }^{170}$ P D G Skegg "Human Tissue Act 1964" (1976) 16 Med Sci Law 197; see also Department of Health Code of Practice for Transplantation of Cadaveric Organs (Department of Health, Wellington, 1987).
} 
living, if this is not in the course of a health care procedure. It also covers the use after death, for a secondary purpose, of tissue taken from the living.

\section{A Structure}

Part 1 of the UKHTA outlines the activities for which consent is required and the criminal penalties that may apply if consent is not obtained. Part 2 sets up an infrastructure to monitor the regulated activities. It describes the remit and membership of the Human Tissue Authority and lists the activities for which a licence must be obtained from the Authority. Provisions in this Part also regulate organ donation and create a criminal offence for commercial dealings ("trafficking") in a limited range of transplantable material. Part 3 includes definitions and a criminal offence for holding DNA with a view to analysing it without consent.

Part I of the HTB gives the purposes and an overview of the bill and defines the terms used, Part II covers the lawful collection and use of all tissue, the consent required for collection and use from cadavers, the consent required for genetic testing other than during a health care procedure, and secondary uses after the living donor's death. Part III creates offences for breaches, such as trading in human tissue.

\section{B Human Tissue Authority}

The UKHTA established an over-arching authority to rationalise existing regulation of activities like transplantation and anatomical examination, and regulate other activities, like post-mortem examinations and the storage of human materials for education, training and research. ${ }^{171}$ The Human Tissue Authority has a licensing remit similar to that of the Human Fertilisation and Embryology Authority. ${ }^{172}$ A variety of activities must be licensed and the Secretary of State may, by regulation, add to, remove, or alter the activities to which the section applies. ${ }^{173}$ This allows for relatively rapid changes; however, there may be a lack of Parliamentary, and thus public scrutiny of many of the key aspects of the legislation and subsequent changes.

Although this thesis suggests that a similar authority is necessary in New Zealand, ${ }^{174}$ the HTB does not propose the establishment of a human tissue authority. It is extraordinary that the need for an overarching body is recognised in the area of assisted reproduction, ${ }^{175}$ yet no such body is to be established with regard to human tissue, a sensitive area similarly affected by new technologies.

\section{Application}

The UKHTA applies to "relevant material", defined as "material, other than gametes, which consists of or includes human cells", ${ }^{176}$ but excluding hair and nails

\footnotetext{
${ }^{171}$ Human Tissue Act 2004 (UK), s 14. United Kingdom Parliament Human Tissue Bill: Explanatory Notes (2003) < http://publications.parliament.uk> (last accessed 27 April 2004).

${ }_{172}$ It is planned to combine the two authorities into the Regulatory Authority for Tissues and Embryos.

${ }^{173}$ Human Tissue Act 2004 (UK), s 16(4).

${ }^{174}$ See chapter 8.

175 The HART Act established the Advisory Committee on Assisted Reproductive Technologies (ACART) to produce guidelines for the ethics committee and advice to the Minister, where necessary.

${ }^{176}$ Human Tissue Act 2004 (UK), s 53.
} 
from a living person and embryos outside the human body." 177 This definition does not distinguish between bodies, body parts, tissues or cells that may be derived from the human body, or the technological artefacts being generated from human materials. Thus, no distinction is made between a whole organ removed post-mortem and a few cells taken as a biopsy, for diagnostic purposes.

Similarly, the HTB applies to human tissue or tissue which is derived from material collected from a living individual or from a cadaver and includes human cells, but does not include an in vitro human embryo or in vitro human gamete. Cell lines derived from human cells are human tissue only for the purposes of clauses 48 and 63, which relate to standards for collection and use of human tissue for nontherapeutic purposes and standards for export and import of human tissue. ${ }^{178}$ Consequently, profit-sharing, in situations such as that in Moore ${ }^{179}$ have not been addressed. Thus, the HTB covers whole bodies, body parts and organs, blood, cell lines derived from tissue, stillborn and foetal material, bodily substances that are excreted or shed by the body naturally, such as hair and urine, but excludes material covered under the HART Act.

\section{Consent}

Section 1 of the UKHTA contains a mandatory requirement to seek consent before carrying out most activities that use cells, tissues or organs of a deceased person. It revises the law governing the storage and use of tissues obtained from living persons and even if tissue might be described as "waste" or "abandoned" that does not mean that a third party can take control of it and use it for their own purposes. ${ }^{180}$ Coroners' investigations are an exception to the consent rule, but the Act is silent about when consent is needed to bury a corpse.

The notion of consent is the fundamental concept unifying the UKHTA, described as its "golden thread". ${ }^{181}$ The scope and specificity of "appropriate consent" 182 is not set out on the face of the Act and these facets will be determined by the Human Tissue Authority or fall to the common law. Commentators have stated that the legislation should rectify the lack of clarity within the common law about the scope and specificity of consent. ${ }^{183}$

The UKHTA only specifies that written consent (from the now-deceased person) is required for anatomical examination and the public display of corpses. Consequently, the implication is that explicit consent is not necessarily required in

\footnotetext{
${ }^{177}$ Gametes and embryos are partially regulated by the Human Fertilisation and Embryology Act 1990. Hair and nails were excluded because of their discardability. Cell lines are also excluded.

${ }^{178}$ Human Tissue Bill, clause 6.

${ }^{179}$ Moore v Regents of the University of California (1990) 793 P 2d 479, 479-97 (Sup Ct Cal) Panelli J, Lucas C J, Eagleson, Arabian and Kennard JJ concurring, Broussard J (concurring and dissenting), Mosk J (dissenting). See the discussion in chapter 3.

${ }^{180}$ Although s 44 permits "surplus tissue" from treatment diagnosis or research to be discarded without consent.

${ }^{181}$ Dr Ladymann HC Standing Committee G col 6627 January 2004 and col 14229 January 2004.

${ }^{182}$ Human Tissue Act 2004 (UK), ss2 and 3.

${ }^{183}$ Cambridge Genetics Knowledge Park and King's College Bioethics Research Centre Report of Human Tissue Workshop King's College Cambridge

$<$ http://cgkp.org.uk/human_tissue/htw_report.doc> (last accessed 14 May 2004).
} 
other circumstances. However, the UKHTA appears to favour the notion of positive consent, rather than a psychological state inferred from a lack of objection. Article 22 of the Council of Europe Convention on Human Rights and Biomedicine states that a part of the human body may only be used for a purpose other than that for which it was removed where it is done in conformity with appropriate information and consent procedures. This indicates that consent is required for each use, which would involve recontacting individuals. This is not the intention of the UKHTA, which appears to envisage generic and enduring consent for "research".

Similarly, the HTB establishes a consent framework for the collection, use, retention and disposal for therapeutic and non-therapeutic purposes of tissue from cadavers. Informed consent is required for genetic testing of tissue taken from living people, in circumstances where the Code does not apply. It is also required for use after death for secondary purposes of tissue taken from a living person. The consent for use of cadavers is consistent with that in the Code ${ }^{184}$ and the definition of informed consent is broadly consistent with that in the Health and Disability Commissioner Act 1994. ${ }^{185}$

The consent structure is one of the weaknesses in the bill. Organ harvest will require the formally recorded consent of the source, or a person nominated by the source to make the decision. ${ }^{186}$ There is no requirement that the nominee should do as instructed by the deceased or make the decision that they believe the deceased would have wished. Clause 45 provides that the consent given by the deceased or the nominee will override any objection by the family or the person lawfully in possession of the body. However, it only says the consent may be acted upon and it is likely that doctors will continue to be unwilling to "snatch" a body in the face of objections by family members. This thesis also recommends that the consent of the source should be paramount, but requires the representative to act as the deceased instructed.

The HTB provides that if "no consent can be given" by the source or the nominee, then the decision will be made by a "majority" of the immediate family. ${ }^{187}$ The definition of "immediate family" is contestable, particularly where more than one culture is represented in the family- a common situation in New Zealand. If no consent can be given by the immediate family, the HTB provides for decision-making by a "senior available next of kin". ${ }^{188}$ This process could result in persons who wish to harvest organs continuing to seek consent until a family member is found who will give consent. The weaknesses of this process include its complexity, which it is likely to lead to conflicts within families and the potential for delays, which may result in the organs being unusable or the source being retained on life support in a brain dead condition for an extended period while consent is obtained. Despite the wish to increase the numbers of organs available, this should not be achieved by continuing

\footnotetext{
${ }^{184}$ Ministry of Health, above, 6.

${ }^{185}$ Human Tissue Bill, clause 7.

${ }^{186}$ Human Tissue Bill, clause 28.

${ }^{187}$ Human Tissue Bill, clause 33. The definition of family is broadly consistent with the Coroners Act 2006. The HTB defines "immediate family" as members of the family who were in a close relationship with the deceased or had responsibility for the deceased's interests, in accordance with the customs and traditions of the deceased's community. Human Tissue Bill, clause 5.

${ }^{188}$ Human Tissue Bill, clause 28(d). Schedule 2 provides a priority list for the senior available next of kin.
} 
non-beneficial treatment of unconscious patients. People often express concerns that their death will be hastened, or that it will be unnecessarily prolonged, in order to enable the harvest of organs.

Clause 3 states that a purpose of the Act is to ensure that collection and use of human tissue occurs only with proper respect for the autonomy and dignity of the source, so it seems extraordinary that there is no requirement to respect sources' vetos (or refusals of consent). There is no provision stating that a veto trumps subsequent familial consent. It is not even clear whether clause 41 would mean that a veto put on the organ register would prevent harvest, as "other donor information" as defined does not include a refusal. However, it is a criminal offence to collect or use tissue from cadavers without consent, although that does not necessarily mean the consent of the source, or even that families have to do what the deceased would have wished.

A national organ and tissue donor register is being established and those proposing to collect organs or tissue will be required to take all reasonable steps (including consulting the responsible person ${ }^{189}$ and checking the register) to ascertain whether consent was given. ${ }^{190}$ The disadvantages of a register include its cost in light of the small number of potential donors, ${ }^{191}$ and the likelihood that donor rates might drop in the short term, as low numbers on the register are anticipated initially and it might be assumed from the absence of an entry that the deceased did not wish to donate. In other countries with consent registers, they have had little impact on donor rates, as professionals continue to consider it unreasonable to retrieve organs without family consent. However, the proposal in this thesis that the representative be required to implement the wishes of the deceased would change this emphasis.

\section{E When Consent Required}

The UKHTA provides that the purposes for which consent will normally be required for storage and use of tissue are: ${ }^{192}$

- $\quad$ Anatomical examination;

- $\quad$ Determining the cause of death;

- $\quad$ Establishing after death the efficacy of a drug or treatment;

- $\quad$ Obtaining scientific or medical information about a living or dead person which may be relevant to another person (including a future person);

- $\quad$ Public display;

- $\quad$ Research in connection with disorders, or the functioning of, the human body;

- Transplantation

\footnotetext{
${ }^{189}$ The responsible person is the person lawfully in possession of the body, such as the person in charge of a hospital; Human Tissue Bill, schedule 1.

${ }^{190}$ Human Tissue Bill, clause 42.

${ }^{191}$ There are only around 100 potential deceased donors in New Zealand each year ( those with organs suitable for donation) and around 40 of those become cadaveric organ donors. There is, therefore, limited potential for a register to increase donation rates.

${ }^{192}$ Human Tissue Act 2004 (UK), Schedule 1, part 1.
} 
No consent is required for the use or storage for any specified purpose of any existing holding from the human tissue archive which was held immediately before the day on which the relevant part of the Act comes into effect.

Part 2 of schedule 1 sets out purposes for which consent will not normally be required, with regard to tissue taken from living persons. These are clinical audit, education or training relating to human health, public health monitoring, quality assurance and performance assessments. Consequently, clinical audit procedures are exempt while research on such tissue will usually require consent. Similarly there is little distinction between public health monitoring and epidemiological "research". Regulations may allow the High Court to issue an order dispensing with the need for consent for research on tissue from living or dead persons in connection with disorders or the functioning of the human body, where this is in the public interest. ${ }^{193}$ This is intended to address extraordinary circumstances and would allow the court to override a refusal of consent to the removal of material from a dead person.

The UKHTA provides that it is lawful for material that came from a person's body in the course of treatment, testing or research, which has ceased to be used or stored for use, to be dealt with as waste, ${ }^{194}$ but it does not specify the status of this waste. ${ }^{195}$

The HTB will establish a consent framework for the collection and therapeutic and non-therapeutic uses of body parts, including the retention and disposal of human tissue from bodies. There will be a requirement, subject to some exceptions, for informed consent for analysis of tissue taken from living people where the Code does not apply and the analysis is for the purpose of obtaining genetic or other information about a particular actual or potential condition, or trait, of the source. There will also be a requirement for informed consent for use for a secondary purpose, after the donor's death, of tissue taken from living persons.

\section{F Research}

One contentious aspect of the original UK Bill was whether generic consent would be sufficient to permit the research use of tissue. If not, further consent would be required if the tissue was to be used for research projects, or projects not explicitly consented to. ${ }^{196}$ Doctors argued that it would be impossible to take and record consents and that specific consent is unnecessary, as most patients are happy to have tissue that is taken from them used for research and teaching. ${ }^{197}$ Such willingness equally supports an argument that consent should be obtained. However, there are logistical and thus budgetary implications involved in obtaining and recording consents.

The government acceded to the demands of biomedical researchers, and so, the UKHTA criminalises the retention and use of tissue for "research in connection with disorders, or the functioning, of the human body" unless the material has come from a

\footnotetext{
${ }^{193}$ Human Tissue Act 2004 (UK), s 7(4).

${ }^{194}$ Human Tissue Act 2004 (UK), s 44.

${ }^{195}$ Schedule 1 activities are prohibited, even if the material is waste.

${ }^{196}$ Parry, above, para 7.

${ }^{197}$ Scott, above.
} 
living person, ${ }^{198}$ the research is ethically approved ${ }^{199}$ and the person from whom the material came cannot be identified. ${ }^{200}$ It also includes "obtaining scientific or medical information about a living or deceased person which may be relevant to any other person (including a future person)." 201

This has compromised the philosophy of the legislation and the logistical concerns could have been addressed by requiring the recording of objections to research use in general, or certain types, of research. If the majority of people would have no objection, this would have been less administratively onerous than recording all consents. This thesis argues that, even if the material is anonymised, human sources retain an interest in their biological materials. They may oppose certain types of research, based on their cultural, ethical or spiritual values. ${ }^{202}$

In New Zealand, the Code states that consumers must be informed of any proposed participation in teaching or research, including being informed whether the research requires and has received ethical approval. ${ }^{203}$ It also requires that consent to participate in research, as part of a health care procedure, must be informed consent, and must be given in writing. ${ }^{204}$ However, Right 7(10) permits unconsented research use, utilising samples that are not necessarily anonymised, with ethics committee approval. $^{205}$

The HTB provides that where consent was obtained for one purpose, but a secondary purpose is proposed, consent to the secondary use must, in general, be obtained. ${ }^{206}$ However, there will be certain limited circumstances where the public good associated with the use of tissue will outweigh informed consent requirements. ${ }^{207}$ These provisions are based on the amendments to Right 7(10) of the Code. ${ }^{208}$ It will make certain exceptions on the need to obtain consent, ${ }^{209}$ including that retained tissue may be tested or disposed of, if that is necessary to avoid endangering public health or safety or where, despite all reasonable attempts, the tissue has not been able to be returned to a family member. ${ }^{210}$ Also, the consent provisions will not cover existing holdings of tissue or existing anatomical specimens of educational, historical or other cultural significance that were retrieved from a human body prior to the legislation coming into force. This will include tissue held by museums, schools of anatomy, and medical schools. ${ }^{211}$

\footnotetext{
${ }^{198}$ Human Tissue Act 2004 (UK), s 1(7).

${ }^{199}$ Human Tissue Act 2004 (UK), s 1(9)(a).

${ }^{200}$ Human Tissue Act 2004 (UK), s 1(9)(b).

${ }^{201}$ Human Tissue Act 2004 (UK), Sch 1 part 1(4).

${ }^{202}$ See the discussion in chapter 8 .

${ }^{203}$ Code of Health and Disability Services Consumers' Rights, Right 6(1)(d).

${ }^{204}$ Code of Health and Disability Services Consumers' Rights, Right 7(6).

${ }^{205}$ Discussed in chapter 3.

${ }^{206}$ Human Tissue Bill, clauses 28-31.

${ }^{207}$ These circumstances include research approved by an ethics committee, professionally recognised quality assurance programmes, or external audit or evaluation activities.

${ }^{208} \mathrm{CAB}$ Min (03) 40/8. See the discussion in chapter 3. The Health (National Cervical Screening

Programme) Amendment Act 2004 also allows the use of cervical smears for evaluation purposes in certain cases without the specific consent of the women involved.

${ }^{209} \mathrm{Such}$ as crime detection and post-mortems.

${ }^{210}$ Human Tissue Bill, clause 21.

${ }^{211}$ Human Tissue Bill, clause 16.
} 
The HTB extends the provision in Right 7(10) of the Code to human tissue from cadavers and provides that unconsented use secondary purposes is permissible, with ethics committee consent, even if the committee knew that informed consent had not been and would not be obtained for the research. ${ }^{212}$ The meaning of this provision is unclear, but it is unfortunate if it includes a situation where it is known that the source would not have wanted to research to proceed.

This thesis proposes greater emphasis on the autonomy of the source of the material, arguing that only in the case of extant material should unconsented use be permitted of material obtained from living or dead bodies and then only if the material is anonymised and the research is not of a sensitive nature. ${ }^{213}$ This is because the sources may be untraceable or dead and a requirement for individual consent might have the effect of rendering existing biobanks unusable for research. With future collection, it is argued that the source, or the representative of a dead source, must give consent to specified research or authorisation for unspecified future research.

\section{G Surrogate consent}

The UKHTA provides that "appropriate consent" refers to the consent given by the deceased, prior to death. If an adult person made no decision, consent may be given by a "nominated representative", if appointed. If not, then a person who stood in a "qualifying relationship" 214 immediately prior to death may consent. With children, consent may be given by a parent, or a person who stood in a qualifying relationship to the child. Once the consent of one qualifying relative has been given, no other relative can veto that consent. Consequently, a relative who knows of an objection by the deceased might be unable to dispute the decision of a relative of the same, or higher, rank. Thus, there is a need for a mechanism to record objections or for a concerted effort to encourage people to appoint a representative.

The HTB provides that sources can appoint nominees to give consent after the source's death. ${ }^{215}$ The appointment may be made orally (before two witnesses), in writing, or in the source's will.

A person over 16 is presumed to be capable of giving consent or making a nomination. ${ }^{216}$ The senior available next of kin of a deceased child under the age of 16 years is a parent, but if no parent is available, it is a guardian of the child and, if the child died with no available guardian, then it is a sibling over the age of 16.

The Gillick approach is not followed with regard to children under the age of 16 and their capacity is based solely on their age. This is contrary to the widely accepted approach based on actual competence. ${ }^{217} \mathrm{~A}$ child under 16 will be able to

\footnotetext{
${ }^{212}$ Human Tissue Bill, clause 23. See the discussion of the amendment to Right 7(10) in chapter 3.

${ }^{213}$ See the discussion in chapter 8 .

${ }^{214}$ Qualifying relationships are set out and ranked in Human Tissue Act 2004 (UK), s 27 (4).

${ }^{215}$ Human Tissue Bill, clause 32. As stated, the nominee is not required to make the decision that the deceased wished.

${ }^{216}$ Human Tissue Bill, clause 43.

${ }^{217}$ Human Tissue Bill, clause 37(2). Note this is based on the child's status as a child rather than competence- see the discussion on chapter 6 .
} 
consent to the non-therapeutic collection or use of tissue to be used for genetic testing, but they can not consent to anything else under the Bill, apparently because it is difficult to decide after death whether a child was competent. However, the same concerns could apply to an adult who was impaired prior to death. This thesis recommends a Gillick approach to consent by children. ${ }^{218}$

The HTB provides for a "responsible person" who is "the person lawfully in possession of the body". The responsible person will, if consulted by a person proposing to harvest tissue from a cadaver, "help" that person to ascertain whether appropriate consent has been given. ${ }^{219}$ The nature of such help in unclear, but intensivists will doubtless continue to believe that there are circumstances in which it is inappropriate to make an approach to the family of a prospective donor. This thesis recommends a less complex provision- that the institution may proceed with the arrangements for organ harvest if the person in control believes in good faith that consent has been given. This is particularly important as the bill introduces criminal liability for collection and use without consent. ${ }^{220}$

\section{H Organ donation}

The cadaveric transplantation consent regime in the UKHTA is similar to the previous practice in the United Kingdom, which has operated an explicit consent policy for many years. The Act will probably increase the influence of relatives, as most people have expressed no opinion about donation prior to death. Although the British Medical Association argued for a presumed consent law, this was not accepted by the government.

Presumed consent is not proposed in New Zealand and the HTB emphasises the role of the family. Although this thesis also recommends a priority list of persons to make the decision should the deceased fail to do so or appoint a representative, the structure is much simpler and has a priority list of decision-makers. Thus, the process would involve less delay and minimise family disputes.

Section 33 of the UKHTA provides that living organ donation or transplantation from a living donor is illegal, unless the Secretary for State has by regulation permitted this to take place and the Human Tissue Authority is satisfied that no reward has been given. This applies to both genetically related and non-related donors. No such provision is proposed in New Zealand, and consent to living organ donation remains within the Code. However, this thesis argues that aspects of living donor transplantation, such as sibling donation, require oversight by an independent authority. ${ }^{22}$

\section{Commercialisation}

The UKHTA prohibits trafficking in human material intended for the purposes of transplantation, ${ }^{222}$ unless the person engaging in the activity is designated by the

\footnotetext{
${ }^{218}$ See chapter 6.

${ }^{219}$ Human Tissue Bill, clause 42.

${ }^{220}$ Human Tissue Bill, schedule 4.

${ }^{221}$. See the discussion in chapter 8 .

${ }^{222}$ Human Tissue Act 2004 (UK), s 32.
} 
Human Tissue Authority as a person who may lawfully do so. ${ }^{223}$ It does not impose a broader prohibition on commercial dealings in bodily material and it exempts gametes, embryos, ${ }^{224}$ hair and nails from a living person, and material that is the subject of property because of an application of human skill. ${ }^{225}$ Initially, this provision also applied to commercialisation of human material for purposes such as research, but the bill was amended in light of concerns from companies involved in drug development and other work involving human tissue. Thus, the distinction between tissue to be used for transplantation and tissue for other purposes fails to fully comply with Article 21 of the Council of Europe Biomedicine Convention.

Human organs and tissue are frequently processed in complex ways, requiring the investment of work and skill. The UKHTA exempts such products from regulation, as they are the property of the scientist or technician who has applied skill in the manufacture. However, it is not specified how much, or how little, skill has to be applied to human tissue to make it the subject of property rights. ${ }^{226}$ There seems little conceptual basis to continue this dubious construct which has its basis in the common law. ${ }^{227}$ It will not, of itself, prevent the commission of offences by commercial companies or remove the contradictions within the common law as to the status of body parts.

Section 4(7) provides that material shall not be regarded as from a human body if it is created outside the human body. Thus, once a cell line is created, it appears to be exempt from the provisions of the Act, although the human source would have had to consent to use of the initial cells. The point at which sufficient work and skill has been applied to transmute the possessory right in the cells into a property right in the cell line is unclear. An alternative interpretation of the UKHTA is that, as the cell line was created outside the body, the Act does not apply anyway. The source will only be able to recover expenses, but the material will be able to be sold by research institutes, subject to the permission of the Authority.

The HTB will prohibit the sale and purchase of tissue (including blood) from both living and deceased people, with exemptions if it is in the public interest to allow such sale or purchase, and it is authorised in writing by the Minister of Health and gazetted. ${ }^{228}$ This provision will authorise hospitals, and the like, to purchase tissue for audit, diagnosis or treatment and receive payment for the expenses incurred in the processing of tissue. Researchers will also be able purchase tissue or imported cell lines for research purposes. The current policy of allowing welfare assistance for living donors would not be affected by this provision.

The HTB does not address the fundamental injustice of permitting parties other than the source to treat body parts as property and thus commercialise them or the issues of profit sharing that are addressed by the framework proposed in this thesis. However, it seems to acknowledge that such parts are property once they pass from the control of the source.

\footnotetext{
${ }^{223}$ Human Tissue Act 2004 (UK), s 32(3).

${ }^{224}$ Gametes and embryos are regulated under the Human Fertilisation and Embryology Act 1990 (UK).

${ }^{225}$ Human Tissue Act 2004 (UK), s 32(a).

${ }^{226}$ See the discussion above.

${ }^{227}$ See the discussion above.

${ }^{228}$ Human Tissue Bill clauses 54-58.
} 


\section{J Philosophical bases}

Neither the UKHTA nor the HTB specify what rights or interests are breached if tissue is stored or used without consent. Price states: "The failure to obtain consent is not a wrong per se; it is not ethically or legally 'self-supporting'." 229 He argues that informed consent relates to medical procedures on living persons, where the person is able to weigh the benefits and risks in deciding whether to undergo a procedure that is potentially harmful and may compromise personal integrity. ${ }^{230}$ In the case of donation of tissue for research or transplantation, any rights do not relate to the infringement of personal integrity in the same sense.

During the Parliamentary debates, it was stated that the UKHTA was based on the right of an individual to control body materials. However it is not clear whether these rights are autonomy rights, privacy rights, dignity rights or property rights. The rhetoric of ownership was expressed in the House of Commons ${ }^{231}$ when it was stated that "we all own our bodies." 232 Despite this, Price asserts that government had no intention of altering the established "no property" rule. ${ }^{233}$

Similarly, the New Zealand Cabinet paper stated: "It has long been considered a matter of common law that there is no property in the body of a deceased person." 234 That document then extrapolated that dubious construct ${ }^{235}$ to propose that tissue may not be sold by the source.

Price argues that the UKHTA is: ${ }^{236}$

...philosophically grounded in property rights and interests even despite the modifications to the Bill obviating the need for consent, but which in any event apply only to non-identifiable tissue as regards research.

Both the UKHTA and the HTB protect the source's right to control excised body parts, while denying that property rights are the rationale for such control. Thus, the basis of both appears to be the infringement of personal integrity. ${ }^{237}$

\section{CONCLUSIONS}

It has been frequently stated that in English law, there is no property in a corpse, thus it cannot be bequeathed. This means that there are people who have rights, duties and liabilities with respect to a corpse, although not proprietary rights, but these are not the deceased persons themselves.

\footnotetext{
${ }^{229}$ David Price "The Human Tissue Act 2004" (2005) 68 MLR 798, 815.

${ }^{230}$ Price, above, 815.

${ }^{231}$ Dr Ladyman "The fundamental principle that we must apply to interpreting the Bill is that material provided by people from their own body is theirs to control, and they must consent to how it is used." HC Standing Committee G col 5927 January 2004.

${ }^{232}$ House of Commons, above, col 65.

${ }^{233}$ Price, above, 816.

${ }^{234}$ Ministry of Health, above, 6 .

${ }^{235}$ See the discussion above.

${ }^{236}$ Price, above, 817 (emphasis in original).

${ }^{237}$ See the discussion of personal rights in chapter 1.
} 
Excised body parts or cadavers have the characteristics of "things", distinct from the person from whose body they were derived and thus are amenable to notions of property. It is necessary to decide who has rights over the corpse, in terms of controlling or authorising its use. Possessory rights are granted for specific purposes to coroners, next of kin, and executors. Possession includes the right of control and yet the traditional view is that there are no property interests in dead bodies or excised body parts, in the absence of work having been carried out to change the nature of the body or body part.

The HTB proposes a complex consent regime, with scant protection for the right to refuse consent for the collection of body parts from the dead. At each level, if consent is not forthcoming, the person wishing to harvest the organs may seek consent from a person on the next level. Organ collection will only require consent from one family member and a lack of expressed opposition from the others. This is insufficiently respectful of the autonomy rights of the living to control what happens to their bodies after death and is likely to result in family disputes.

This thesis proposes legislation which provides that a property interest held by the deceased person arises briefly at the point of death. After death, that interest will pass to the representative or if the deceased failed to appoint a representative, the highest person on the priority list. ${ }^{238}$ Direct evidence of the deceased's wishes would be honoured irrespective of the views of relatives, as with the disposition of other property by way of a will. If the deceased appointed a representative, but expressed no preferences as to the disposition of the body, the representative would have the decision-making power, based either on substituted judgment, or in accord with the representative's own preferences.

This approach is similar to that in the UKHTA and reflects the individualistic, libertarian nature of our culture. However, the individualistic approach may be inappropriate in cultures where such decision making is considered a collective matter, or where elders or other relatives are considered the appropriate persons to make such a decision. In such cultures, individual property interests in the human body may be culturally offensive. The proposed framework would be sufficiently flexible to encompass such a world view, as the source could choose a kaumatua ${ }^{239}$ as the representative and/or instruct the representative to dispose of the body in accord with cultural imperatives. Any new framework should only be introduced after careful consultation and, in particular, after consideration of Māori cultural preferences. ${ }^{240}$

Some people might argue that to fail to harvest all tissue and organs suitable for recycling, or to fail to adopt a system of presumed consent, indicates a lack of moral progress in the valuation of human life. However, presumed consent or conscription may be perceived as an assault on the autonomy of living persons, who wish to control the disposition of their bodies. Relatives may believe they should retain control over the corpse of a deceased family member and that their interest

\footnotetext{
${ }^{238}$ See the discussion in chapter 8 . An administrator who obtains a grant of administration will assume the role of representative.

${ }^{239}$ Elder.

${ }^{240}$ See the discussion in chapter 5 .
} 
trumps the previous views of the deceased or the needs of prospective organ recipients.

These are complex issues and consensus is unlikely. Treating bodies and tissues as property would provide strong protection of personal autonomy, but has costs in terms of possible losses to the collective interests in transplantation and research. The suggested approach treats the cadaver in a similar manner to other property and promotes the interests of human sources over the interests of family or those who would benefit from use of the cadaver, because of the resultant conceptual and practical benefits. 


\section{Chapter 3}

\section{BODY PARTS FROM THE LIVING}

\section{INTRODUCTION}

This chapter considers body parts excised from living persons. Unlike the cases considered in chapter 2, some of which apply the work and skill exemption to cadavers, the cases in this chapter tend to be based on public policy considerations rather than specifically relying on potentially relevant theories of property, such as first occupancy or labour.

This chapter builds on the argument in chapter one that the interests of the sources of biological materials would be more effectively achieved by a legislative framework incorporating notions of property rights, than relying solely on informed consent. It suggests that property rights underlie the present treatment of body parts and the denial of them by the courts is little more than a convenient fiction that has arisen because of concerns that such rights could chill research and lead to the sale of organs.

It also considers whether additional protection is necessary for living organ donors and concludes that a property construct alone cannot prevent conflicts of interest and protect sources, especially those who are vulnerable. However, it concludes that sufficient protection should be achieved through procedural guidelines that emphasise a right to withdraw at any stage which, together with the professionalism of medical professionals, would result in a refusal to proceed if there was apparent reluctance to donate.

\section{ORGANS AND CELLS}

\section{A Moore}

John Moore suffered from hairy-cell leukaemia. He consented to treatment involving the removal of his spleen, but he was unaware that Dr Golde planned to retain part of it for research purposes. His cancerous blood cells possessed Tlymphocyte features, only the second such recorded occurrence in medical literature. ${ }^{1}$

For seven years he regularly returned, ostensibly for treatment of his condition. Samples of blood, blood serum, skin, bone marrow aspirate and sperm were taken and used, without his knowledge, for research. A cell-line was developed using genetic engineering, with an estimated commercial value of \$US3 billion. Moore had not been informed of this use or the value of his tissue.

\footnotetext{
${ }^{1}$ A T-lymphocyte is a type of white blood cell. T-lymphocytes produce lymphokines, or proteins, that regulate the immune system. Some lymphokines have potential therapeutic value. If the genetic material responsible for producing a particular lymphokine can be identified, it can sometimes be used to manufacture large quantities of the lymphokine, through the techniques of recombinant DNA. Moore's T-lymphocytes were interesting to the defendants because they overproduced certain lymphokines, thus making the corresponding genetic material easier to identify.
} 
When he was asked to sign a complex consent form, he refused. However, commercial exploitation of his cell line continued, and the name of the cell line was altered to avoid detection. In 1984, the researchers received a patent for the cell line and assigned the rights to the University of California. When Moore eventually discovered these actions, he sued, seeking damages based on 13 causes of action, including conversion of his spleen.

Conversion derived from the common law action of trover. To maintain an action in trover, the plaintiff had to allege possession of certain goods, that the goods had been lost, that the defendant found the goods and instead of returning them the defendant converted the goods to his or her own use. Gradually, the elements of losing and finding the goods were not required. The plaintiff needed only to demonstrate a right to possession and the fact of conversion of the personal property by the defendant. The plaintiff was entitled to damages amounting to the full value of the personal property at the time of conversion.

The Californian Court of Appeal held that Moore's spleen was an item over which he had "an unrestricted right [of] ... use, enjoyment and disposition and thus it fits under the traditional legal provisions of property." ${ }^{2}$ It held that Moore could claim that the defendants had converted his tissue and held that he had not abandoned his spleen. The Court noted that the "intense moral, religious and ethical concerns" that could accompany the use of a person's body or body part without consent made an inference of abandonment, even of a diseased organ, "inappropriate". ${ }^{3}$

The Supreme Court held that spleen cells are not the property of the person from whose body they are withdrawn. ${ }^{4}$ It stated that human biological materials were considered by the law as sui generis and their disposition regulated in deference to public policy considerations, rather than "abandoning them to the law of personal property." 5 It stated that should Moore be granted a property right, this would set a precedent that would have a chilling effect on medical research. ${ }^{6}$ In any event, it was not necessary to recognise a property right, as he had an appropriate remedy based on lack of informed consent. ${ }^{7}$ However Broussard J (dissenting) stated: ${ }^{8}$

It is clear under Californian law that a patient has the right, prior to the removal of an organ, to control the use to which the organ will be put after removal. It is also clear, under traditional common law principles, that this right of a patient to control the future use of his organ is protected by the law of conversion.

The majority held that the defendants failed to convert Moore's cells, because he abandoned them when the doctors removed them from his body, but they could

\footnotetext{
${ }^{2}$ Moore v Regents of the University of California (1988) 249 Cal Rptr 494, 504.

${ }^{3}$ Moore $v$ Regents of the University of California, above, 510.

${ }^{4}$ Moore v Regents of the University of California (1990) 793 P 2d 479, 479-97 (Sup Ct Cal) Panelli J, Lucas C J, Eagleson, Arabian and Kennard JJ concurring, Broussard J (concurring and dissenting), Mosk J (dissenting).

${ }^{5}$ Moore v Regents of the University of California (1990) 51 Cal 3d 120, 137 (Sup Ct Cal) Panelli J.

${ }^{6}$ Moore $v$ Regents of the University of California, above, 154 Panelli J.

${ }^{7}$ Moore $v$ Regents of the University of California, above, 164 Panelli J.

${ }^{8}$ Moore v Regents of the University of California (1990) 793 P 2d 479, 502 (Sup Ct Cal) Broussard J.
} 
become the property of the scientists who harvested them and transformed them into a valuable cell-line, as a proprietary interest arose once a patent was issued.

\section{$1 \quad$ Policy arguments}

The policy arguments supporting the researchers’ property right included:

- $\quad$ the need to ensure an adequate supply of biological materials;

- $\quad$ the importance of economic incentives for research; and

- $\quad$ the need for certainty of title to research materials.

The Supreme Court held that to allow an action in conversion could hinder research and product development by restricting access to necessary raw material. However, the court did not point to any empirical evidence that recognition of sources' property rights would chill research. It further argued that such a right would damage the free exchange research culture but, as Mosk $\mathrm{J}$ stated, ${ }^{9}$ the biotechnology research industry is already commercialised and so there is limited free exchange. Both economic incentives and certainty of title are possible if the source has title, as this can be transferred by sale or gift and good research practice requires adequate record keeping.

Another policy concern was to ensure that parties who engage in socially useful activities, such as medical researchers, are not threatened with civil liability. Conversion is a strict liability offence, so if a patient owned cells excised from his or her body and had not abandoned them, he or she might be entitled to their return or to compensation for their market value, even if the researcher did not know that the cells belonged to someone else.

Had Moore succeeded in conversion, future researchers could have obtained detailed consents, such as the form that Moore refused to sign. As tissues used in research usually come from multiple sources and the products are not based directly on a specific component in one, a property interest would not necessarily adversely impact on the progress of scientific research. Even if it did have some minor impact, this thesis argues that such concerns are outweighed by the importance of the principle that sources should be able to determine what is done with their body parts.

The Court attempted to solve the problem by separating the sticks in the bundle, by distinguishing the power to determine disposition from the ability to sell and by tying the separation to the different causes of action alleged in the complaint. It accordingly upheld the action for breach of fiduciary duty because of the failure to secure informed consent, while dismissing the action for conversion.

It held that physicians must tell their patients if they have personal research or economic interests unrelated to the patient's health, which might affect their judgment. Breach of fiduciary duty depends on the doctor's failure to inform the patient of circumstances that may affect the patient's decisions about medical care,

\footnotetext{
${ }^{9}$ Moore v Regents of the University of California, above, 513, Mosk J.
} 
rather than any wish to share in the profits from the doctor's research. A patient who knows that the doctor may derive a benefit from a given course of care may (for example) want a second opinion, but that would have been unlikely to change the course of treatment. Moore's leukaemia was life-threatening and removal of his spleen was not elective surgery. At most, he might have chosen subsequent care closer to home, instead of continuing to travel to California. The doctors' duty to inform him of their potential conflict of interest has little to do with Moore's desire to negotiate the most lucrative arrangement possible, in return for consent to use his spleen. This approach can protect patients from physicians who collect tissue, but it does not protect them from researchers, employers and other institutions that may be collecting or testing tissue samples without the person's consent.

The Court avoided consideration of the distinction between a property interest sufficient to assert decision making power and one that would permit sale of human cells, by appearing to deny the existence of any property interest at all. Panelli $\mathrm{J}$ stated: ${ }^{10}$

\begin{abstract}
It may be that some limited right to control the use of excised cells does survive operation of the statute. There is, for example, no need to read the statute to permit "scientific use" contrary to the patient's expressed wish. A fully informed patient may always withhold consent to treatment by a physician whose research plans the patient does not approve. That right, however, as already discussed, is protected by the fiduciary-duty and informed-consent theories.
\end{abstract}

This passage, however, misses the distinction between the remedies to the two causes of action. If the doctors sold Moore's tissue in violation of his expressed wishes, what would be the measure of damages? Moore consented to the surgery, and appeared at that time to have no special attachment to his cells. His only real loss was the market value of his tissue. If the court were to award such a remedy, it would in effect have created an action for conversion. To refuse to do so may render meaningless the breach of informed consent (in the sense of the above quote). The court did not apply the Doodewood "11 "work and skill" argument that creation of a cell line resulted in the specimen acquiring features beyond its mere existence, although cell lines could arguably fall within this exception.

Moore's tort claims for breach of fiduciary duty and lack of informed consent for removal of his spleen were allowed to proceed and were eventually settled.

\title{
$3 \quad$ Waste
}

The researchers argued that Moore's spleen was "waste", as he would not expect, or wish, to retain it. There are two different senses of the word "waste", either superfluous matter that is normally shed or cast away, or matter that is useless or valueless. The spleen might have been waste in the first sense, but not in the second. Categorising it as waste suggests it was valueless, yet, in the age of biotechnology, human tissue certainly does have value. The California Court of Appeals suggested that the extraordinary lengths to which Golde had gone to obtain

\footnotetext{
${ }^{10}$ Moore v Regents of the University of California (1990) 793 P 2d 479, 488 (Sup Ct Cal) Panelli J.

${ }^{11}$ Doodeward v Spence (1908) 6 CLR 406 (HCA). See the discussion in chapter 2.
} 
specimens for his research demonstrated his belief in the value of the tissue. ${ }^{12}$ Moore is now one of many individuals whose cell lines can be ordered by perusing the American Type Culture Collection, or one of its foreign counterparts. ${ }^{13}$

Moore affirms a person's right to exclude others from taking body parts without consent, while it simultaneously protects the researchers' rights in the resultant cell-lines. Rao argues that Moore is capable of at least three different constructions: ${ }^{14}$

- $\quad$ The Court's refusal of Moore's conversion claim was recognition that body parts cannot be property so long as they are contained in a living human being. Rao suggests that the Court could have recognised Moore's ownership of his spleen at the point it was detached from his body, without making his whole person a form of property;

- $\quad$ Even if the spleen was initially Moore's property, its "owner”, for whom the diseased organ was valueless, had abandoned it and thus it was available to be used by another;

- $\quad$ The Court may have implied that body parts, once removed, return to the public commons, available to all, and become a form of communal property available for "capture" by the first person who recognises their commercial potential and puts them to productive use.

\section{B Subsequent US Cases}

In Miles Inc $v$ Scripps Clinic and Research Foundation, ${ }^{15}$ there was a property dispute between researchers. Dr Zimmerman provided Scripps-Miles with an antigen, later used to create a monoclonal cell line whose antibodies possessed an affinity for Factor VIII:C. ${ }^{16}$ When the corporation dissolved, Miles acquired the laboratory. However, Zimmerman and Scripps continued to use the cell line for research and eventually obtained a patent for a process utilising the antibodies to produce purified Factor VIII:C. Miles sued Zimmerman and Scripps, alleging conversion and breach of fiduciary duty. The District Court held that although, because of the decision in Moore ${ }^{17}$ California law appears to recognise a right to commercialise a cell line, conversion fails to protect this intangible right. The Court distinguished this case from Moore, because Miles had a property interest in the

\footnotetext{
${ }^{12}$ Moore $v$ Regents of the University of California (1990) 51 Cal 3d 120, 126 (Sup Ct Cal) Panelli J.

${ }^{13}$ American Type Culture Collection <http://www.atcc.org> and World Data Centre for Microorganisms <http://wdcm.nig.ac> (last accessed 18 September 2003). John Moore’s cells are for sale as CRL-8066.

${ }^{14}$ Radhika Rao “Property, Privacy, and the Human Body” (2000) 80 BUL Rev 359, 374.

${ }^{15}$ Miles Inc v Scripps Clinic and Research Foundation (1991) 951 F 2d 361 (9 $9^{\text {th }}$ Cir).

${ }^{16}$ Factor VIII:C is a substance that permits a hemophiliac's blood to clot. Without Factor VIII:C, hemophiliacs run great risks of blood loss. Purified Factor VIII:C serves this vital function without risk of transmitting AIDS or hepatitis through treatment. For a general discussion of the use of Factor VIII:C, see Scripps Clinic \& Research Foundation v Genentech, Inc (1991) 2d 1565, 1568 (Fed Cir). ${ }^{17}$ Moore v Regents of the University of California (1988) 249 Cal Rptr 494, 215 Cal App 3d 709 (App Div) modified (1990) 51 Cal 3d 120, 271 Cal Rptr 146, 793 P 2d 479 cert denied (1991) 499 US 936.
} 
commercialisation of the cell line. In Moore ${ }^{18}$ the plaintiff's raw materials led to the creation of a cell line, whereas in Miles, "the cell line is the starting point."19

The Court refused to extend California conversion law to cover Miles' intangible right and stated that such a decision is "more appropriately the subject of legislative deliberation and resolution." ${ }^{20}$ It noted that conversion is as a strict liability tort and stated that contract law and patent law protections are adequate to protect personal interests. The case was dismissed.

In United States $v$ Arora,${ }^{21}$ it was alleged that Arora had tampered with culture flasks leading to cell deaths. A civil suit was filed against Arora for conversion or trespass. The Court held that, in Maryland, a cell line exists as a form of property capable of being converted. Although Arora did not steal the cell line, it was alleged that he had interfered with, destroyed, or altered its nature, thus satisfying an allegation of conversion. The court distinguished Miles ${ }^{22}$ by concentrating on the differences between an actual cell line and the intangible right to commercialisation.

In Cornelio $v$ Stamford Hospital, ${ }^{23}$ the plaintiff wished to recover pap smear slides containing her genetic material. She argued in the Superior Court of Connecticut that she had a property interest in the slides. The Court compared pathology slides with x-rays and stated that neither are the property of the patient. They are the property of the doctor, although the patient is given access to them. The plaintiff argued that it is difficult to equate slides, which contain human cells, to an x-ray or personal notes made by a doctor as part of a patient's case file, because the slides contain human substances drawn from the patient's body, which are incapable of being duplicated or reproduced. The Court applied Moore ${ }^{24}$ stating that the source does not have a right to possess cells following their removal. It pointed to the consent form signed by the plaintiff, which concluded with the words "...including the right to dispose of all tissue" and applied contract law reasoning to determine that the plaintiff did not retain a property interest in her cells.

The decision was upheld in the Supreme Court. McDonald J dissented, stating that "one principle that formerly appeared deeply ingrained in our society and in our law is that one controls one's body." ${ }^{25}$ He further stated that: "The decision now severely restricts the patient's control over her own cells at a time when the advance of genetic science should raise very wide privacy implications." ${ }^{26}$

Most of the cases considering property rights in human biological materials relate to established cell lines. The Canavan case considers the rights of the sources

\footnotetext{
${ }^{18}$ Moore v Regents of the University of California (1990) 51 Cal 3d 120, 149 (Sup Ct Cal) Panelli J.

${ }^{19}$ Miles Inc. v Scripps Clinic and Research Foundation (1991) 951, 1097 F 2d 361 (9 ${ }^{\text {th }}$ Cir) Rhoades SR.

${ }^{20}$ Miles Inc. v Scripps Clinic and Research Foundation, above, 1096 Rhoades SR.

${ }^{21}$ United States v Arora (1994) 860 F Supp 1091, 1093 (D Md) Messitte J.

${ }^{22}$ Miles Inc. $v$ Scripps Clinic and Research Foundation (1991) 951 F 2d 361 (9 $9^{\text {th }}$ Cir).

${ }^{23}$ Cornelio v Stamford Hospital (1997) WL 430619 (Conn Super Ct ) aff'd by (1998)717 A 2d 140 (Conn).

${ }^{24}$ Moore v Regents of the University of California (1990) 51 Cal 3d 120, 137 (Sup Ct Cal) Panelli J.

${ }^{25}$ Cornelio $v$ Stamford Hospital, above, 149 McDonald J.

${ }^{26}$ Cornelio v Stamford Hospital, above, 149 McDonald J.
} 
of the raw materials if there if there is no doctor/patient relationship, when such rights conflict with the rights of researchers, .

\section{Canavan Children}

Canavan is a rare genetic disorder. If a child inherits two copies of the Canavan gene, it will develop an untreatable fatal condition. ${ }^{27}$ The Greenbergs had two children with Canavan disease. They sought out Dr Matalon and convinced him to research the disease. They raised money for the research, provided him with tissue samples from their children and found other families to participate in the research. This was done with the understanding and expectation that the samples and information would be used for the specific purpose of researching Canavan disease and identifying gene mutations, which could lead to carrier detection within their families and benefit the public at large. It was anticipated that carrier and prenatal testing would be provided on an affordable and accessible basis and that the research would remain in the public domain, to promote the discovery of more effective prevention techniques and treatments and, eventually, a cure for Canavan disease.

In 1993, Matalon successfully isolated the gene responsible for Canavan disease. The families continued to provide tissue and blood for the research. In 1997, Matalon obtained a patent, then began charging a fee and restricting the use of the diagnostic test. The families claimed that they did not know of the patent application until 1998. They alleged that they were not informed of the defendants' intentions to seek a patent on the research, commercialise the products of the research and restrict access to Canavan testing.

In 2000, the families sued Miami Children's Hospital for breach of fiduciary duty, fraudulent concealment, conversion, misappropriation of trade secrets, unjust enrichment, and breach of informed consent. They sought a permanent injunction restraining the defendants from enforcing their patent rights. They were concerned that research on Canavan would be slowed because access to information and testing would be limited by excess fees, making it difficult for other researchers to conduct new investigations and that the availability of diagnostic testing would be reduced.

The defendants filed a motion to dismiss and, in May 2003, the motion was granted in part. ${ }^{28}$ The decision with respect to the various grounds of the claim is as follows:

\footnotetext{
${ }^{27}$ The body cannot produce an enzyme, aspartoacyclase, which leads to the build up of another enzyme that destroys the myelin sheath that protects brain cells. Symptoms usually appear between three and six months of age and most children die between 10 and 15 years of age.

${ }^{28}$ Greenberg and others v Miami Hospital Research Institute and others (Greenberg) (2003) $264 \mathrm{~F}$ Supp 2d 1064 (SD Fla).
} 
It was held that medical consent law applies to medical researchers in certain circumstances. The issue was whether this duty extended to disclosure of a researcher's economic interests. The Court distinguished Moore ${ }^{29}$ because there the researchers did not inform the patient that they were using his blood and tissue for research, whereas in Greenberg the defendants were solely medical researchers and there was no therapeutic relationship. Moreno $\mathrm{J}$ stated: ${ }^{30}$

\begin{abstract}
In declining to extend the duty of informed consent to cover economic interests, the Court takes note of the practical implications of retroactively imposing a duty of care of this nature. First, imposing a duty of the nature that the plaintiffs seek would be unworkable and would chill medical research as it would mandate that researchers constantly evaluate whether a disclosable event has occurred. Second, this extra duty would give rise to a type of dead-hand control that research subjects could hold because they would be able to dictate how medical research progresses. Finally, these plaintiffs are more accurately portrayed as donors rather than objects of human experimentation, and thus the voluntary nature of their submissions warrants different treatment.
\end{abstract}

Consequently, in the United States, informed consent is only required if treatment is being provided, although this is not so in New Zealand. ${ }^{31}$ Further, the UNESCO Universal Declaration on Bioethics and Human Rights ${ }^{32}$ provides: ${ }^{33}$

Scientific research should only be carried out with the prior, free, express and informed consent of the person concerned. The information should be adequate, provided in a comprehensible form and should include modalities for withdrawal of consent.

Informed consent is an important tool for protecting donors, but it is not the universal ethical panacea imagined by some commentators. ${ }^{34}$ In particular, it does not address the issue of principled apportionment of the benefits of successful research. ${ }^{35}$

\title{
$2 \quad$ Breach of fiduciary duty
}

In Moore ${ }^{36}$ the Court stated that a physician's duty included a fiduciary duty to disclose information that is material to a patient's decision. This included a duty to disclose personal interests, whether research or economic, that may affect the physician's medical judgment. In Greenberg, ${ }^{37}$ it was held that this is a two-way relationship, and a fiduciary relationship will only be found when the plaintiff

\footnotetext{
${ }^{29}$ Moore v Regents of the University of California (1990) 51 Cal 3d 120 (Sup Ct Cal).

${ }^{30}$ Greenberg and others v Miami Hospital Research Institute and others, above, 1070 Moreno J.

${ }^{31}$ Health and Disability Commissioner Act, s 2. The Code applies to a "health care procedure” which means "any health treatment, health examination, health teaching, or health research administered to or carried out on or in respect of any person by any health care provider; and includes any provision of health services to any person by any health care provider."

${ }^{32}$ UNESCO Universal Declaration on Bioethics and Human Rights Adopted on 19 October 2005 by the $33^{\text {rd }}$ session of the General Conference of UNESCO.

${ }^{33}$ UNESCO, above, article 6 (2).

${ }^{34}$ See the discussion in chapter 1.

${ }^{35}$ This is a particular concern of indigenous populations. See chapter 5.

${ }^{36}$ Moore $v$ Regents of the University of California (1990) 51 Cal 3d 120 (Sup Ct Cal).

${ }^{37}$ Greenberg and others v Miami Hospital Research Institute and others (2003) 264 F Supp 2d 1064 (SD Fla).
} 
separately alleges that the plaintiff placed trust in the defendant, and the defendant accepted that trust.

The plaintiffs alleged that the defendants accepted the trust by undertaking research that they represented as being for the benefit of the plaintiffs. The defendants successfully asserted that the plaintiffs did not allege any facts showing that the trust was recognised and accepted. It was held that there is no automatic fiduciary relationship when a researcher accepts research donations, as the acceptance of trust, which is the second element of a fiduciary duty, cannot be assumed.

In New Zealand, doctors and patients do not have a fiduciary relationship as such, ${ }^{38}$ although the Code provides: ${ }^{39}$ "Before making a choice or giving consent, every consumer has the right to the information that a reasonable consumer, in that consumer's circumstances, needs to make an informed choice or give informed consent.” Deliberate failure to disclose and deceit could amount to negligence, or an equitable breach such as fraud, duress or undue influence. ${ }^{40}$

\section{Unjust enrichment}

This claim required the plaintiffs to establish that they conferred a benefit on the defendant and that the defendant knew of the benefit. The defendant must have voluntarily retained the benefit, and it must be shown that under the circumstances it would be inequitable for the defendant to retain it without paying for it.

It was accepted that the plaintiffs conferred a benefit on the defendants, but they argued that the plaintiffs did not suffer a detriment, as they received what they sought-the successful isolation of the Canavan gene and the development of the screening test. The plaintiffs argued that, had they known that the defendants intended to commercialise their genetic material, they would not have provided the benefits to the defendants on those terms. The Court held that obtaining a patent did not preclude the defendants from being unjustly enriched, stating “...the facts paint a picture of a continuing research collaboration that involved [p]laintiffs also investing time and significant resources in the race to isolate the Canavan gene." ${ }^{41}$ The claim for unjust enrichment was allowed to proceed.

\section{$4 \quad$ Fraudulent concealment}

This claim failed because there was no duty of disclosure, as there was no fiduciary relationship. Additionally, the facts were not fraudulently concealed, because a patent becomes public knowledge when issued, thus the plaintiffs could have discovered the patent application. It was not accepted that the plaintiffs were unable to make reasonable inquiries because they had no reason to believe patenting would occur. In New Zealand, the Code provides that: "Every consumer has the right

\footnotetext{
${ }^{38}$ Sidaway v Bethlem Royal Hospital [1985] 1 All ER 643 (HL).

${ }^{39}$ Health and Disability Commissioner (Code of Health and Disability Services Consumers' Rights) Regulation 1996, Right 6(2).

${ }^{40}$ Gerald Dworkin and Ian Kennedy "Human Tissue: Rights in the Body and its Parts” (1993) 1 Med L Rev 291, 308.

${ }^{41}$ Greenberg and others v Miami Hospital Research Institute and others, above, 1072 Moreno J.
} 
to be free from discrimination, coercion, harassment, and sexual, financial or other exploitation." ${ }^{42}$ Exploitation includes any abuse of a position of trust, breach of a fiduciary duty, or exercise of undue influence. ${ }^{43}$ Thus a complaint could be made in such circumstances. However, it is unlikely that the resolution of a complaint would result in an apportionment of the profits from a patent.

The Court applied Moore ${ }^{44}$ and held that there was no property interest in body tissue and genetic information given voluntarily to researchers. These were donations to research, without any contemporaneous expectation that they would be returned. Moreno J stated: "Plaintiffs have no cognizable property interest in body tissue and genetic matter donated for research under a theory of conversion." 45 The Court held that the patented research outcome is both factually and legally distinct from excised material used in the research. The material was used for the agreed purpose, namely research, and it was the fruits of the research that were commercialised. Thus, the patent cut off all the sources' rights, even though they were not claiming that they were solely entitled to the patent and wished merely to retain a degree of control over the research outcomes.

\section{$6 \quad$ Misappropriation of trade secrets}

The plaintiffs claimed that the Canavan registry was a trade secret that was misappropriated. The Court held that even if the registry was a trade secret, which was doubtful, it was not misappropriated. The hospital did not know that the registry was a confidential trade secret guarded by the plaintiffs, nor that the researcher had acquired it through improper means. There was no explicit authorisation of the purposes for which the information could be used. "Plaintiffs cannot donate information that they prepared for fighting a disease and then retroactively claim that it was a protected secret.”,46

The case would have proceeded on unjust enrichment alone, but in September 2003, the parties reached a confidential settlement that provided for continued royalty-based genetic testing by certain licensed laboratories and royalty-free research by institutions, doctors and scientists searching for a cure.

\section{Washington University v Catalona ${ }^{47}$}

Moore related to a cell line and Greenberg to the patenting of a genetic test, but Catalona directly related to the ownership of biological samples. Washington University claimed ownership of biological materials, including prostate specimens, stored in the GU Biorepository. The defendant was a surgeon and researcher into prostate cancer. The participants in the research, many of whom had been his patients, signed informed consent forms stating they could not claim any ownership

\footnotetext{
${ }^{42}$ Code of Health and Disability Services Consumers’ Rights Regulation 1996, Right 2.

${ }^{43}$ Code of Health and Disability Services Consumers’ Rights Regulation 1996, reg 4.

${ }^{44}$ Moore $v$ Regents of the University of California (1990) 51 Cal 3d 120 (Sup Ct Cal).

${ }^{45}$ Greenberg and others v Miami Hospital Research Institute and others, above, 1074 Moreno J.

${ }^{46}$ Greenberg and others v Miami Hospital Research Institute and others, above, 1077 Moreno J.

${ }^{47}$ Washington University v Catalona (2006) US Dist LEXIS 22969 Limbaugh J.
} 
rights to any medical or scientific product, and including a right to withdraw their consent at any time. A brochure advised that the tissue would be identified and destroyed on request. When Catalona left the university, he contacted the participants, suggesting that they request the university to transfer the samples to him at Northwestern University.

Limbaugh $\mathrm{J}$ held that the participants were donors, who had made a gift of the materials to Washington University. It became the absolute owner when it took delivery and accepted the samples. The right to discontinue participation meant no more than that the person had chosen to provide no further materials. He stated that Washington University was the sole and exclusive owner of all biological samples and associated clinical data in the Repository and that researchers and research participants had no legally recognised ownership right.

Under Missouri law, exclusive possession and control of personal property is prima facie evidence of ownership and anyone else claiming such property bears the burden of proof. Limbaugh $\mathrm{J}$ found that it was undisputed that Washington University had been in exclusive possession of the material, in part because the University was solely responsible for the maintenance of the Repository, which was housed on University property. Also, the University signed all material transfer agreements, by which outside parties could obtain samples for research from the Repository. The University had consistently asserted its ownership interests in the materials, through its intellectual property policy. The University alone had the legal, regulatory and compliance risks from all research done in connection with the Repository and he found no compelling federal authority prohibiting Washington University from asserting an ownership interest in the samples.

Limbaugh J rejected Catalona's arguments that:

- The exculpatory language in the informed consent forms invalidated the gift; and

- The research participants' right to discontinue participation included a right to control and transfer the samples.

He stated that the public policy considerations supporting his decision were that medical research can only advance if access to these materials by the scientific community is not thwarted by public agendas and that such open access is best assured by placing responsibility for, and authority over, biological samples with institutions. He emphasised the benefits of medical research and stated: ${ }^{48}$

If left unregulated and to the whims of a [research participant], these highlyprized biological materials would become nothing more than chattels going to the highest bidder.

He argued that it is antithetical to the goals of science and public health to allow research participants to direct the recipient of a sample and doing so would be tantamount to a blood donor being able to dictate that the blood can only be infused into a person of a certain ethnic background. Additionally, institutional ownership

\footnotetext{
${ }^{48}$ Washington University v Catalona, above, 48.
} 
would avoid the buying and selling of human tissue. Both of these arguments are questionable. Living donors commonly specify the recipients of organs. A donor's ability to limit research use to a particular researcher will not inevitably lead to discrimination and many people may wish to direct their interest to particular programmes or else they may refuse to participate at all. The second argument ignores the fact that tissue is a commonly bought and sold biotechnological resource.

Limbaugh $\mathrm{J}$ stated that the issue was whether the participants retained ownership rights, so they could direct the use of the material and transfer it to third parties. ${ }^{49}$ This, together with the emphasis on a completed gift to the university, signalled that the sources had property interests prior to the gifts being made, which then passed to the university. As such, had the sources made their contribution subject to the ability to withdraw the samples should Catalona leave the institution, then a completed gift would not have been made, as no intention to make an unconditional gift would be evident. If the university accepted the samples on such conditions it would have a contractual arrangement with the sources, similar to those entered into with researchers by PXE International. ${ }^{50}$

\section{E Comment on Cases}

In Moore and Greenberg it was held that research participants are donors, who part with ownership rights once biological materials are excised for medical research and pass into the possession of researchers. In Catalona, it was held that the sources had made unconditional gifts of their property to the university.

Greenberg indicates that the courts are reluctant to impose limits on researchers' economic exploitation of discoveries, in the absence of express agreements about the rights of contributors. Moreno J stated that the legal principles adopted must not "cripple" the ability of researchers to carry on their work. Although this is an important concern, public policy should also encourage the participation and support of affected individuals. If researchers are free to use samples, information and funding from family members to develop tests and therapies that are priced beyond their reach, then support for research will diminish.

Catalona demonstrates the weakness of reliance on informed consent alone. The consent forms gave the sources the right to withdraw from the research and, in some versions, the right to have the specimens destroyed. ${ }^{51}$ Limbaugh $\mathrm{J}$ held that this meant no more than they had chosen to provide no more materials and he accepted that the university could then destroy the samples, store them indefinitely without any further use, or anonymise them and continue to use them in research. Moreover, the forms referred throughout to "your" tissue. It was not unreasonable for sources to conclude that to "withdraw" meant that they could claim their samples back. The university relied on its intellectual property policy to justify its ownership. Although the sources may have been able to access this policy, it is unlikely they would

\footnotetext{
${ }^{49}$ Washington University $v$ Catalona, above, 21.

${ }^{50}$ See the discussion below.

${ }^{51}$ Under the section "What if you change your mind?" The brochure stated "To request that your tissue no longer be used for research, you should call the investigator listed on the consent form. Your tissue will be identified and destroyed on request. Any research results already obtained cannot be destroyed or recalled.” Washington University $v$ Catalona, above, 6.
} 
undertake research beyond the informed consent form and unreasonable to expect them to do so. Consequently, the sources were not fully informed.

The Court held that the sources "had the present intent to make inter vivos gifts; i.e. donations of their biological materials to WU for medical research." ${ }^{52}$ It referred to the specimens as "personal property" 53 and accepted that the sources had passed property to the university by way of gift.

Moore ${ }^{54}$ concluded that informed consent provided sufficient respect and protected Moore's interests. The consent model and the prospect of property interests were treated as mutually exclusive, and yet there appears no reason why this must be so. Sources have personal rights, so tissue cannot be excised without appropriate prior consent. This thesis argues that at that stage, they have an inchoate property right, which becomes a full property right once the tissue is excised. They could agree to abandon the tissue, in which case the researcher would assume full property rights over the tissue. Alternatively, they could agree to transfer it under certain conditions, such as for particular research purposes.

If researchers act contrary to these wishes then, prima facie, sources have an action for conversion. The normal remedy of damages for conversion relates to the value at the time of conversion, together with consequential and foreseeable damage. Alternatively, sources might be permitted to claim some of the profit from any patent and its products, which could be seen as the improved products of their cells or they could seek equitable remedies, such as delivery up or an account of the profits.

\section{THE CONTEXT OF THE RESEARCHER/CONTRIBUTOR RELATIONSHIP}

\section{A Collection of Samples}

For two centuries, body parts and tissues have enabled researchers to acquire information about illnesses and behaviours. ${ }^{55}$ Some research, such as studies of the prevalence of a particular disease, or the identification of a disease gene, requires tissue samples from a large number of individuals. Consequently, researchers wish to gain access to tissue specimens that were collected for other purposes and thereafter retained. $^{56}$

Specimens may come from tissue removed in the course of screening, diagnostic or therapeutic procedures, autopsies or voluntary donation. Biobanks are also being created de novo by the collection of material and health data from representative portions of certain populations. ${ }^{57}$ Commentators argue that the scientific and commercial potential of biobanks may not be realised if there is uncertainty over the ownership of the archived material and that obtaining consent

\footnotetext{
${ }^{52}$ Washington University v Catalona, above, 19.

${ }^{53}$ Washington University $v$ Catalona, above, 12.

${ }^{54}$ Moore v Regents of the University of California (1990) 51 Cal 3d 120, 127 (Sup Ct Cal) Panelli J.

${ }^{55}$ Lori Andrews and Dorothy Nelkin Body Bazaar (Crown Publishers, New York, 2001).

${ }^{56}$ Such collections are commonly referred to as "biobanks".

${ }^{57}$ Such as UK biobank, Iceland and Estonia.
} 
from individual sources is time consuming, expensive and, in the case of historic collections, may be impossible. Additionally, some researchers argue that studies on blood, cell lines, or genes should be exempt from consent because they use replenishable tissue and consent undermines biomedical research. ${ }^{58}$

However, the basic moral premise of research is that people are entitled to refuse to participate. Blanket (or generic) consent is not a solution, because sources may wish to put limits on the types of research that may be carried out on their samples and have no way to foresee the directions future research may take. ${ }^{59}$ The Code requires that health consumers be notified of any proposed participation in teaching or research, including whether the research requires and has received ethical approval. ${ }^{60}$ They should be given such information as a reasonable consumer would require, which arguably includes the type of research, the time frames and so on.

To give sources control over the uses of their body parts does not necessarily mean that they should have a financial interest in, or property rights in, resultant patents or cell lines. However, it is commonly accepted that sources have the right to control whether donation will occur. There seems to be no principled reasons for requiring that a gift of a body part must be unconditional and pass all rights of control to the researcher or transplant hospital. Conditional gifts are already commonplace in other contexts, including living organ donation. ${ }^{61}$

The right to withdraw from research is a method of control and it appears in many international instruments. ${ }^{62}$ Similarly, the Code gives the right to have body parts returned. ${ }^{63}$ A solution may be that if material has been stored for a certain period without being reclaimed by the source, it will be treated as though it has been abandoned. An alternative approach is to specify in the original consent that recontact will only occur for a set period and thereafter, if the source is unable to be located, certain steps will be taken. ${ }^{64}$ The source will be able to decide whether to provide the material or not, in light of this information.

The consent may be limited to certain types of research or for a certain time period, with additional consent required for any other use, so long as the samples have not been completely anonymised (which renders recontact impossible). The

\footnotetext{
${ }^{58}$ Eliot Marshall “Policy on DNA Research Troubles Tissue Bankers” (1996) 271 Science 440.

${ }^{59}$ See the discussion in chapter 8.

60 Health and Disability Commissioner (Code of Health and Disability Services Consumers’ Rights) Regulation 1996, Right 6(d). However, Right 7(10) allows unconsented research use, with ethics committee approval.

${ }^{61}$ Also in other contexts, such as an endowment to a university for a specified purpose.

${ }^{62}$ World Medical Association Declaration of Helsinki -Ethical Principles for Medical Research Involving Human Subjects Adopted by the $18^{\text {th }}$ WMA General Assembly, Helsinki, Finland June 1964 Para 22; Council of Europe Bioethics convention Article 5 part II "The person concerned may freely withdraw consent at any time”; Office for the Protection from Research Risks Issues to Consider in the research use of stored data or tissues <http://www.hhs.gov/ohrp/humansubjects/guidance/reposit.htm> (last accessed 17 September 2006).

${ }^{63}$ Health and Disability Commissioner, above, Right 7(9).

${ }^{64}$ Either that the material will be destroyed or that it will be used for research without further consent.
} 
United States National Bioethics Advisory Commission recommended a range of options, to enable donors to specify the extent and limits of their consent. ${ }^{65}$

The concern that property rights in such samples would hinder research can be countered by the argument that most people support research, but oppose commercial entities being allowed access to databases. ${ }^{66}$ Most individuals would find that their property was of minimal economic significance to researchers, ${ }^{67}$ and the value difficult to quantify, ${ }^{68}$ but the issues arising are not solely those of profit sharing. Sources may wish to limit the types of research using their body samples, or may not wish to be involved in research at all.

\title{
B European Guidelines
}

The Council of Europe instrument on the use of archived human biological materials in biomedical research built on the principles in the Convention on Human Rights and Biomedicine and the Protocol on Biomedical Research, to protect human rights and dignity with respect to research on human biological materials. ${ }^{69}$

Human biological material is defined as material of human origin, whether identified identifiable or anonymised, ${ }^{70}$ but the instrument does not apply to research on unlinked anonymised human cell lines or stem cell lines. ${ }^{71}$ It permits unconsented use of irreversibly anonymised material. ${ }^{72}$

Identified or identifiable material may only be stored and used for a secondary purpose if this is done in conformity with appropriate information and consent procedures. However, for research on anonymised materials, the verification of the anonymisation process by a competent body is sufficient and no consent from the source of the materials is required.

\begin{abstract}
This approach is criticised by Trouet who states: ${ }^{73}$
Human biological materials are more than information; even anonymised they are not neutral to the person from whom they derive. The source can be opposed to certain uses of his (anonymised) cells or tissues for fear of stigmatisation of the group to which he belongs, he might want to exclude them from certain uses if this goes against his personal convictions (whether religious, spiritual, o[r] emotional).
\end{abstract}

\footnotetext{
${ }^{65}$ National Bioethics Advisory Commission Research Involving Human Biological Materials: Ethical Issues and Policy Guidance (National Bioethics Advisory Commission, Maryland, 1999) Recommendation 9.

${ }^{66}$ H Busby “Blood Donation for Genetic Research” in R Hutton and O Corrigan (eds) Genetic Databases: Socio-ethical Issues in the Collection and Use of DNA (Routledge, London, 2004) 39—54. ${ }^{67}$ See the discussion in chapter 7.

${ }^{68}$ Medical Research Council Code of Practice for the Use of Human Stem Cell Lines Annex 2a $<$ www.mrc.ac.uk> (last accessed 17 September 2006).

${ }^{69}$ Council of Europe Instrument on the use of archived human biological materials in biomedical research (2002) <http://www.coe.int> (last accessed 16 April 2004). The proposal was approved on 20 June 2003.

${ }^{70}$ Council of Europe, above, Article 2.

${ }^{71}$ Council of Europe, above, Article 3.2

72 The researcher is unable to obtain any further information about the source, or recontact the source of the materials.

${ }^{73}$ C Trouet "New European Guidelines for the Use of Stored Human Biological Materials in Biomedical Research" (2004) 30 J med ethics 99.
} 
Some European countries, such as the Netherlands and Iceland, have regulations that offer the source of biological materials a say in their retention and use, even when they are anonymised. ${ }^{74}$ There are similar regulations proposed in France and Belgium.

\section{C “Guthrie” Test Samples}

In New Zealand, determination of the status of biobanked samples arose with respect to the "Guthrie" or "heel prick" samples, which are collected to screen newborns for genetic disorders and thereafter retained indefinitely. ${ }^{75}$ In $H \vee G,{ }^{76} \mathrm{a}$ putative father sought to disprove paternity of a deceased child, by DNA testing of the Guthrie sample. He relied on the provisions in the High Court Rules permitting inspections of "property". 77 Salmon J stated: "I have no doubt that the samples come within the very wide definition of property contained in the Rule and I find accordingly." ${ }^{\text {,7 }}$ He held that samples taken for a specific purpose were permitted to be used for the unanticipated secondary purpose. The man had a legitimate interest in knowing whether he was the father of a living child and this could be extended to a deceased child, so that he could have certainty on the issue and be able to grieve properly. Such interests overrode the objections of the mother. This was a decision directed to these particular facts, rather than signalling a wider conception of property in body parts, but it illustrates ethical concerns about secondary uses of biobanked samples.

In $S \vee T,{ }^{79}$ a man applied for a child to be placed under the guardianship of the court, to take a buccal swab to determine whether he was the father. O'Regan J indicated that if the mother did not facilitate the taking of the swab, he would place the child under the guardianship of the court. The decision was upheld in the Court of Appeal, which agreed that the child's welfare would be enhanced by having the issue of paternity resolved. ${ }^{80}$ The Guthrie card was unavailable for paternity testing, because the mother had uplifted it. O'Regan J accepted that, as a parent, she had the right to do so, without commenting on the legal status of the sample.

The cards are held indefinitely, unless the parents (or the adult child) request their return. The number of requests to have them returned rose from none in 1995 to 775 in $2002 .^{81}$ The collection of blood samples is, potentially, a valuable research resource. The Privacy Commissioner stated that there was no adequate legal

\footnotetext{
${ }^{74}$ Trouet, above, 100.

${ }^{75}$ Approximately 1.9 million samples are retained by the National Testing Centre, which is a division of Auckland Healthcare.

${ }^{76}$ H v G (14 May 1999) High Court Auckland M1868/98 Salmon J.

${ }^{77}$ High Court Rules, Rule 322(3): "In this rule property includes any land and any document or other chattel, whether in the ownership, possession, custody, or power of a party or not.”

${ }^{78} \mathrm{H} v \mathrm{G}$, above, 5 Salmon J.

${ }^{79} S$ v T [2003] NZFLR 223 (HC) O’Regan J.

${ }^{80} T$ v $S$ [2005] NZFLR 4 para [60] (CA) Anderson P, Hammond and William Young JJ.

${ }^{81}$ Information about the mother and the child is retained even if the sample is released. Privacy

Commissioner Guthrie Tests (Privacy Commissioner, Wellington, 2003). The rate of requests for return has remained at a similar level since 2002.
} 
protection for the samples against access by third parties, or against future uses. He recommended that:

- The Ministry of Health allocate clear responsibility and authority for the operation of the newborn metabolic screening programme;

- $\quad$ That the resultant body move urgently to develop clear rules for retention of the samples and any further use or third party access to those samples after consultation with stakeholders and the Privacy Commissioner;

- $\quad$ These rules and permission-granting structures should be "incorporated in legislation in such a way that they are clear, robust and enforceable”.

In response to the report, control of the samples passed to the Ministry of Health's national screening unit in July 2005. In 2006, the Ministry announced the joint signing of a Memorandum of Understanding with the New Zealand police, clarifying the circumstances in which the samples may be used for forensic purposes, such as the identification of dead bodies. The Ministry is formulating guidelines for ethics committees when considering proposals for use of biobanked samples, ${ }^{82}$ which allow for blanket consent for future use of samples, so long as the sources have been specifically advised that they will not be informed of the uses of the samples and that they will thereafter lose all future control over them. In addition, the Ministry will shortly undertake consultation on the future research use of the Guthrie sample collection. ${ }^{83}$

If the Guthrie samples are the child's property, with the mother having privacy interests in the information held about her, the child, once competent, would have the right to control the uses of the samples, but not necessarily the maternal information. Alternatively, as the parents could have uplifted the cards, ${ }^{84}$ but have not done so, it could be argued that the samples have been abandoned. The parents could abandon the samples, as proxies for their incompetent children, but only if they were aware that the cards were retained and that they had the right to uplift them. This does not equate to a property interest, but acknowledges that sources retain an interest in the disposition of body parts.

There is an increasing tendency to apply presumed consent to the use of biological samples and to allow access to the medical records of participants in screening programmes. ${ }^{85}$ An opt-out system, which allows access to test samples and medical records impinges on patients' interests and may alienate participants in screening programmes.

\footnotetext{
${ }^{82}$ Ministry of Health Guidelines on the Use of Human Tissue for Future Unspecified Research Purposes: Discussion Document (Ministry of Health, Wellington, 2006). See the discussion in chapter 8.

${ }_{83}$ Ministry of Health The Consent, Storage and Use of Newborn Blood Spot Cards: a Public Consultation Draft (Unpublished- copy held by author).

${ }^{84}$ The Code gives the right to the return of the cards. Health and Disability Commissioner (Code of Health and Disability Services Consumers' Rights) Regulation 1996, Right 7(6): "Every consumer has the right to make a decision about the return or disposal of any body parts or bodily substances removed or obtained in the course of a health care procedure.”

${ }^{85}$ Health (National Cervical Screening Programme) Amendment Act 2004, s 112ZF only applies to the National Cervical Screening Programme, but the Act provides that it could be extended to any other screening programme, by an Order in Council.
} 


\section{Amendment to the Code}

In 2004, Right 7(10) of the Code was amended to permit the use of bodily substances or body parts for:

- $\quad$ research that has received the approval of an ethics committee;

- $\quad$ a professionally recognised quality assurance programme; or

- $\quad$ an external audit or evaluation of services that is undertaken to assure or improve the quality of services. ${ }^{86}$

This allows unconsented use of biobanked samples, ${ }^{87}$ whilst retaining the right of the human source to reclaim them. ${ }^{88}$ Ethics committees have the onus to ensure that ethical standards are maintained, rather than control remaining with the sources. ${ }^{89}$ However, just because it is legally permissible to use unconsented samples in research does not mean the use is ethical, so ethics committees may still require informed consent before approving a proposal. ${ }^{90}$

In light of this amendment, the consent procedures when samples are taken must emphasise to parents the potential uses of the samples. Without this information, they will be unable to exercise their Code rights, especially Right 7(9). A reasonable parent would expect to be given such information, which enables parents to decide whether to consent to the original taking of the sample, and whether to request the return of the cards after testing. ${ }^{91}$

\section{E Anonymisation of Samples}

Targeted research on biological samples is impossible if the samples are not identified, but other research, such as epidemiological studies to determine the prevalence of a genetic mutation in the population, can be conducted on de-identified samples. Biobanked tissue has significant potential value for population studies, which may help government and health administrators plan for the future community health needs. The collections can be used to study the interaction of genetic and environmental factors in disease over time, to examine the causes of genetic diseases and to locate genetic mutations. Through such research, new diagnostic tools and treatments can be developed, which will have economic and medical value.

Only blanket consent is possible for future, yet to be determined, research. Effectively, participants are consenting to not being informed about the types of research. Ellis and Mannion state: "The key to solving this dilemma of using

\footnotetext{
${ }^{86}$ Cabinet Minute “CAB Min 40/8 03” (8 December 2003). The amending regulation came into force on 11 June 2004.

${ }^{87}$ With ethics committee approval.

${ }^{88}$ Health and Disability Commissioner (Code of Health and Disability Services Consumers' Rights) Regulation 1996, Right 7(9).

${ }^{89}$ Ethics committees are considered further in chapter 8.

90 Joanna Manning “Heath Care Law Part 2-Legislative Developments” [2004] NZ Law Rev 385, 395.

${ }^{91}$ Anecdotal evidence suggests that either consent processes are inadequate or, if they do take place, that many parents have little or no recall of the information.
} 
unconsented samples has to be in anonymising the samples."92 There are two main forms of anonymity. Absolute anonymity arises if there are no means available to link the data to an identifiable individual. Proportional or reasonable anonymity exists when there are no reasonable means of identification of specific individuals. ${ }^{93}$ This applies when anonymity is achieved by using linked or linkable coded information, with access to the link appropriately controlled.

Anonymisation may reduce the risk of harm through misuse of information, but it is not an absolute protection, in light of the use of increasingly sophisticated computers with the capacity to search multiple databases. It does not allow for objection to the uses of the samples and although it reduces the quality of the relationship that individuals have with their samples, but does not extinguish it. Public policy may dictate that other interests weigh more heavily than individual autonomy in the decision to allow the use of anonymised samples, but the potential for harm to individuals from cultural or personal concerns about certain types of research and from discrimination remains. ${ }^{94}$ If the samples remain the property of the sources until transfer of ownership, remedies would be available for misuse, theft and unauthorised use.

\section{F $\quad$ Res Nullius}

Biological material removed from a living person might be regarded as res nullius, a corporeal item in the ownership of nobody. It would be reduced into possession by the first person to obtain physical control with the intention to exercise control over it and the source would be afforded no prior interest. The Nuffield Council stated that an analysis based on res nullius would reflect the traditional approach of no property in the body. ${ }^{95}$

Such a concept may not serve the interests of the source or the researcher. If the material passes into the absolute ownership of the hospital or doctor controlling the removal and intending to appropriate it, this might defeat the source's justifiable interest in its use or disposition and also the purpose for which the material was collected, such as transplantation or research.

\footnotetext{
${ }^{92}$ I Ellis and G Mannion "Humanity versus Utility in the Ethics of Research on Human Genetic Material” (2001) 1 Genetics Law Monitor 1, 1.

${ }^{93}$ Graeme Laurie Genetic Privacy (Cambridge University Press, Cambridge, 2002) 295.

${ }^{94}$ Havasupai Tribe v. Arizona State University 3:04-CV-1494 (D Ariz); Tilousi v Arizona State University 3:04-CV-1290. The research suggested that the people had migrated to Arizona from Asia, which was offensive to the tribe who believe that the Grand Canyon is the birthplace of the human race. Additionally, it alleged that the schizophrenia research is stigmatising. Paul Rubin "Indian Givers” (27 May 2004) Phoenix New Times <http:www.phoenixnewtimes.com> (last accessed 12 October 2006). See the discussion in chapter 5.

${ }^{95}$ Nuffield Council on Bioethics Human Tissue: Ethical and Legal Issues (Nuffield Council on Bioethics, London, 1995) 9.11.
} 


\section{G Waste}

People undergoing medical tests or surgical procedures do not usually expect the return of removed body parts or tissues. However, the value and variety of uses are increasing, so this habitual lack of concern may change. They commonly abandon biological materials, such as hair and fingernail clippings. In $R \vee X{ }^{96}$ a diplomat, who ejaculated on his nanny's hair while she feigned sleep, argued that the hair with semen on it was inadmissible, because it constituted the "person of a diplomatic agent." It was held that X's "person" had not been interfered with and there was no breach of Vienna Convention on Diplomatic Relations 1961, as nothing had been done to detain or arrest or somehow constrain $\mathrm{X}$ to obtain the sample, nor was it in any way procured through agents of the government. Although not necessary for the decision, it was held that the concept of ownership of semen and genetic material was complex but, if necessary to do so, the Court would find that the semen was abandoned, or discarded, by the man.

Hospitals regard blood and tissue as waste-something over which the patient has given up any claim. It is routine to either store such tissue or destroy it. ${ }^{97}$ It is a highly relative notion whether an item may be considered waste and dependent on context. A person who has blood taken for diagnostic tests would normally anticipate no further use of it. However, if the blood was later used for research that was not for the benefit of the patient, the patient might consider that this use was not legitimate and not regard the surplus blood as a waste product. Had John Moore been aware of the proposed uses of his spleen, he would not have viewed it as surgical waste.

Bernard Dickens suggests that a valid approach: ${ }^{98}$

...may be to consider the human source as having an inchoate right to property in materials issuing from his body, which right he may expressly or by implication abandon to another, or similarly make prevail over a contending claim.

Dickens states that if the person does nothing to indicate an intention to assert the right of ownership, possession, or control over such materials, the inference is that the person intends to abandon the materials. The property interest in the materials would then pass to the hospital.

The working party of the Nuffield Council on Bioethics proposed that tissue removed from patients in the course of treatment should be considered abandoned, but if it is voluntarily donated, any claim to it would be based on the terms of the donation. ${ }^{99}$ Abandonment suggests the prior existence of proprietary rights to abandon. As informed consent attempts to prevent harms before they occur, it should be given before the research takes place. The ability to object to research use recognises that sources have a definitive interest in what will happen to excised body parts. This contradicts the view that once removed from the body such materials become waste. ${ }^{100}$

\footnotetext{
${ }^{96} R v X$ (18 October 2004) Court of Appeal CA 299/04 McGrath, Hammond, William Young JJ.

${ }^{97}$ Jean McHale "Waste Ownership and Bodily Products” (2000) 8 Health care anal 123.

${ }^{98}$ Bernard Dickens “The Control of Living Body Materials” (1977) 27 U Toronto L J 142, 183.

${ }^{99}$ Nuffield Council on Bioethics, above, 13.26.

${ }^{100}$ Arthur L Caplin "Blood, Sweat, Tears, and Profits: The Ethics of the Sale and Use of Patient Derived Materials in Biomedicine” (1985) 33 Clinical Res 448, 450: "[I]n the area of commercial
} 
Organs are typically donated specifically for transplantation, rather than being removed as part of ongoing medical treatment, except in situations such as those involving a domino heart transplant procedure. In the case of living organ donation, the framework proposes that property in the severed organ vests in the donor, until corporeal reintegration occurs in the recipient. The doctor, or hospital, with physical possession of the organ would not obtain legal ownership, but would only be a bailee of the organ, required to take reasonable care of it. The proprietary duty would be owed to the donor, not to the recipient. Consequently, deliberate destruction or misuse could amount to unlawful conversion. ${ }^{101}$

\section{H Adequacy of Informed Consent to Protect Sources}

The Code is premised on individual choice. Consumers must be able to make an informed choice and have the right to make a decision about the return or disposal of any body parts or bodily substances removed or obtained in the course of a healthcare procedure. ${ }^{102}$ The consumer must be given such information that a reasonable consumer, in that consumer's circumstances, needs to make an informed choice or give informed consent. This, presumably, would include information about the nature of the research, what the research hopes to accomplish and who will medically and financially benefit from it. The Code does not address the issue of apportionment of profit resulting from research. The consent relates to the initial collection, but must be sufficiently expansive to include subsequent uses of tissue.

Beyleveld and Brownsword suggest: ${ }^{103}$

There is a distinction between rights relating to the taking of body parts and rights relating to the use and control of body parts. Moreover, once we are contemplating rights of the latter kind, we are in the natural territory of property rights.

They argue that if it is accepted that a person has a protected interest in the uses to which body parts may be put, because there is some form of privileged relationship between the person and the body parts, this can only be justified by way of property rights. The personal rights, such as the right to bodily integrity will not be further impaired once the parts have been excised, so proprietary rights must be involved.

Informed consent requires that doctors and researchers explain the treatment and research to sources prior to operating, removing material, or medical testing. Consent normally requires an explanation of the procedure and being apprised of the risks. However, consent forms do not commonly indicate that the research may culminate in a patent application, or that a patent would legally allow restricted access to any patented medical treatment or testing. Even if the forms did include

biotechnology...the biological materials involved are almost always replenishable and often constitute waste materials, at least from the point of view of the donor."

${ }^{101}$ Bernard Dickens "Excised Organs Prior to Implantation: Belonging and Control” (1990) 22

Transplantation Proceedings 1000. See the discussion of Calavito v New York Organ Donor Network (2006) 438 F 3d 214 (US App Ct) Sack J in chapter 2.

${ }^{102}$ Health and Disability Commissioner (Code of Health and Disability Services Consumers’ Rights) Regulation 1996, Right 9.

${ }^{103}$ Deryck Beyleveld and Roger Brownsword “My Body, My Body Parts, My Property?” (2000) 8 Health Care Analysis 87, 90. 
such information, it is doubtful whether persons with limited treatment options, or desperate for discoveries to ameliorate conditions, are in any position to negotiate the waiver of intellectual property rights. ${ }^{104}$ Sources assume that the outcomes of research on their biological materials will be available for them and other similarly afflicted persons. ${ }^{105}$

Even if no commercialisation is anticipated early in the research, this may change if a potentially lucrative discovery is made. As it appears onerous to be required to recontact numerous contributors to seek further consent, consent forms are commonly phrased in very general or vague terms, such as that "there are no present plans" to share the proceeds with contributors. This is unsatisfactory, as a reasonable person might wish to take commercialisation into account when deciding whether to contribute.

Charlotte Harrison suggests further inequality may arise because: ${ }^{106}$

\begin{abstract}
Enterprising contributors may seek to negotiate better arrangements for themselves than are offered to others. Medical institutions can be caught in a difficult position, recognizing the equitable claims of contributors, but ill-equipped to provide payment to everyone and reluctant to create a double standard by compensating only those who demand it.
\end{abstract}

The current emphasis on autonomy in western bioethics has focussed on informed consent as the only means of respecting and empowering individuals in their dealings with health care professionals and researchers. Consent does provide protection for researchers and is one means of respecting individuals, but it does not necessarily empower them, even if it does supply an illusion of control. The only power the research subject has is to refuse to consent and there is no residual ability to exert ongoing moral and legal influence over samples once consent is given, unless further consent is required. In contrast, property rights protect and empower individuals, particularly if combined with other protections, such as autonomy, confidentiality and privacy.

\title{
I PXE International and the University of Hawaii
}

It seems accepted that sources have the right to control tissues while they are still part of their bodies and, if they are aware of the potential value prior to excision, they can treat them as a marketable commodity. Collaborative schemes provide for reimbursement of research expenses and distribution of a percentage of subsequent profits to the researchers and their funding sources. A patient advocacy group which has developed such a scheme is PXE International Inc, established by a couple who discovered that two of their children had a genetic disease, PXE. ${ }^{107}$ They sought out

\footnotetext{
${ }^{104}$ See the discussion in chapter 7.

${ }^{105}$ See chapter 7 for patenting of life form inventions.

${ }^{106}$ Charlotte H Harrison "Neither Moore nor the Market: Alternative Models for Compensating Contributors of Human Tissue” (2002) 28 Am j law med 77, 85.

${ }^{107}$ Pseudoxanthoma elasticum, which causes the connective tissue in the skin, eyes and arteries to calcify. PXE International Inc "What Is PXE?” <http://www.pxe.org> (last accessed 15 December 2004).
} 
people with PXE, and asked them to provide blood and tissue samples. ${ }^{108}$ The foundation stores the samples and raises research funds.

The biobank was made available to researchers who agreed to joint possession of any intellectual property rights and to share profits from discoveries. PXE also requires that any genetic test be made available to the foundation. Researchers at the University of Hawaii agreed to these conditions and used the samples to isolate the gene responsible for the disease. PXE and the University filed a joint patent application, which was granted on 24 August 2004. However, although the gene has been discovered, its operation has not yet been determined, so no test is available to detect who carries the gene and no treatment is available.

Unlike the Canavan families, PXE International negotiated directly with the scientists and entered into contractual arrangements to give research support and materials, in return for a share of the patent rights. The contract has not been legally challenged and so its enforceability has not been tested, but it could be argued that the contract is void as against public policy on the grounds that research participants cannot possess property rights in their tissue, pursuant to Moore. However, if the courts do recognise the rights of such participants to negotiate for property rights in the commercial products developed from their tissue, it is illogical and unjust to deny such rights to those in the position of the Moore and Greenberg plaintiffs from whom researchers withheld vital information about their intentions to commercialise their scientific findings. ${ }^{109}$

Courts may adopt a contextual approach, with the results in particular cases dependent on the way they are framed. Consequently, patient groups may be able to dictate the terms of the use of the biobanks they have set up, whereas claims by individual research participants to restrict or profit from each use of their biological material may be denied, based on public policy arguments that large biobanks would then be likely to be underused and informed consent requirements would, by necessity, become complex. Bovenberg argues that "property rights in such material [should] vest in the entity that has lawfully collected and stored the material", because the collections are a global public good. ${ }^{110}$ However, if as Catalona ${ }^{111}$ suggests, the source initially has property in the material, the question is whether the biobank has lawfully collected the material, if the consent process was inadequate.

\footnotetext{
${ }^{108}$ Anne Nichols Hill “Note: One Man’s Trash is Another Man’s Treasure, Bioprospecting: Protecting the Rights and Interests of Human Donors of Genetic Material” (2002) 5 J Health Care L \& Pol'y 259, 278.

${ }^{109}$ Donna M Gitter “Ownership of Human Tissue: A Proposal for Federal Recognition of Human Research Participants’ Property Rights in their Biological Materials” (2004) 61 Wash \& Lee L Rev 257, 267.

110 Jasper A Bovenberg Property Rights in Blood, Genes and Data: Naturally Yours? (Martinus Nijhoff, Leiden, 2006) 147.

${ }^{111}$ Washington University v Catalona (2006) US Dist LEXIS 22969 Limbaugh J.
} 
This thesis proposes that a property interest arises after body parts have been excised. Consequently, at the time living donors give consent, the interest has not yet arisen; however, the consent also covers the subsequent transplantation into the recipient. The proposed framework would allow remedies should the organ be misused. In Colavito, ${ }^{112}$ both the intended recipient and the widow of a dead donor had a cause of action, so it is arguable that living sources should have similar rights.

Donors may be willing to take excessive risks in the interests of assisting others, particularly those with whom they have a close emotional tie. The public policy problem is determining the point at which the donors' ability to transfer their organs should be restricted. Restrictions may be justified because consent was not freely given, or because the risks were excessive. This section argues that such restriction would not preclude the notion of property and it concludes that the issues arising should be dealt with by way of administrative processes, rather than regulation.

Deceased donors are the primary sources of transplantable organs. However, the growing disparity between the availability of, and need for donor organs has lead to a rapidly increasing reliance on living donors. ${ }^{113}$ In the United States in 2001, the total number of living organ donors $(6,528)$ exceeded the total number of deceased organ donors (6,081). ${ }^{114}$ Between 1990 and 1999, 87 per cent of living donors and recipients were biologically related and 13 per cent unrelated. ${ }^{115}$

Living donation initially only involved kidneys, but now has been extended to pancreases, livers and lungs. Donation was originally restricted to emotionally connected parties, but recently there have been non-directed donations from living donors. Concerns relate to informed consent, psycho-social considerations and concern for the welfare of the donor.

Results of LDT of kidneys are better than cadaveric transplantation. ${ }^{116}$ Analysis of renal data from 1987 to 1995 showed the one-year and five-year survival rates for wholly incompatible living related and unrelated kidney donors were comparable to the figures for identically matched cadaveric transplants, and much superior to the results where the cadaver donors were mismatched to any degree. ${ }^{117}$ This is probably because of closer tissue compatibility and less ischemia time. The

\footnotetext{
${ }^{112}$ Colavito v New York Organ Donor Network Inc (2006) 438 F 3d 214 (US App) Sack J. See chapter 2.

${ }^{113}$ Roger Dobson “More women than men becoming living donors” (2002) 325 BMJ 851. In the United States, living donor transplants account for more than one third of transplanted kidneys.

${ }^{114}$ UNOS "Who we Are, History, Timeline of Key Events in US Transplantation and UNOS History" <http://www.unos.org/WhoWeAre/history.asp> (last accessed 1 October 2003).

${ }^{115}$ The majority of living unrelated transplantations are from spousal donors. Liise K Kaylor and others "Gender Imbalance and Outcomes in Living Donor Renal Transplantation in the United States" (2003) 3 Am J Trans 452.
}

\footnotetext{
${ }^{116}$ N Lefrancois and J Touraine "Living Kidney Donation: Preoperative Evaluation and Preparation for Surgery” in G Collins and others Procurement Preservation and Allocation of Vascularized Organs (Kluwer, Dordrecht, 1997) 1, 3.

117 J Cecka and P Terasaki "Living Donor Transplants: Superior Success Rates Despite Histoincompatibilities” (1997) 29 Transplantation Proceedings 203, 203.
} 
organs are likely to be in better condition, and the surgery takes place while the recipient is still relatively well.

For healthy kidney donors, the risk of dying ranges from 1 in 2,500 to 1 in 4,000. ${ }^{118}$ However, liver transplantation is much more complex. Transplantation of the right hepatic lobe from live donors has been technically feasible since the mid1990s. If an adult donates a modest portion of the liver to a child, the mortality rate is in the region of 1 in 500 to 1 in 1000, but if the recipient is another adult, up to 60 per cent of the donor's liver must be removed. The mortality risk is then around 1 in 100.

\section{A Gender Issues}

There is an increasing donor gender imbalance. In 1988, the female to male donor ratio in the United States was 1.2 (55 per cent female versus 45 per cent male) which rose to 1.4 in 1998 (58 per cent female versus 42 per cent male). A study at a Canadian transplant centre found that 36 per cent of wives who were able to donate did so, compared with 6.5 per cent of husbands. However, although more women donate, more men are recipients. In the United States, females are less likely to be on the kidney transplant waiting list and wait-listed females are less likely to receive either a cadaveric or living renal transplant. ${ }^{119}$ This disparity exists not only among spouses, where female to male donation rates represent 68-73 per cent of cases, but also between biological relatives, with more mothers, daughters and sisters donating, and more fathers, sons and brothers receiving, kidney allografts. ${ }^{120}$

Research indicates that males may have greater ambivalence about donation, and may be less available or less able to donate. ${ }^{121}$ Men have a higher incidence of coronary artery disease and hypertension and the impact of lost wages may reflect on the availability of a primary income earner to undergo the operation. ${ }^{122}$

Strickling argues that women's self-abnegation is such that there may be no "self" beyond their identification with others. ${ }^{123}$ In its negative form, the selfabnegator abandons any sense of being a particular self outside of her relationships. Such women are vulnerable to suggestions that they should allow their body materials to be used for the benefit of others.

Questions arise about such decision-making, especially in cultures where women are subservient. The ethic of care would suggest that cultural and social traditions and expectations are part of a valid decision-making framework. However,

\footnotetext{
${ }^{118}$ Christine Gorman and David Bjerklie “The Ultimate Sacrifice” (2002) 159 Time 40781.

${ }^{119}$ Liise K Kaylor and others "Gender Imbalance and Outcomes in Living Donor Renal Transplantation in the United States” (2003) 3 Am J Trans 452, 452.

${ }^{120}$ Liise K Kaylor and others "Gender Imbalance in Living Unrelated Donor Renal Transplantation” (2002) 73 Transplantation 248, 248.

${ }^{121}$ R Simmons and S Klein The Social and Psychological Impact of Organ Transplantation (Wiley, New York, 1977) 14.

${ }^{122}$ Liise K Kaylor and others "Gender Imbalance and Outcomes in Living Donor Renal Transplantation in the United States” (2003) 3 Am J Trans 452, 452.

${ }^{123}$ Bonnelle Lewis Strickling “Self-Abnegation” in C Overall, L Code and S Muller (eds) Feminist Perspectives: Philosophical Essays on Method and Morals (University of Toronto Press, Toronto, 1988) 190, 194.
} 
radical feminists might argue that this is a result of the imbalance of power that causes women to feel unable to refuse consent. Property rights do not address this problem; however this thesis does not suggest that consent processes should differ for women. Rather, robust consent procedures should be instituted to recognise and address these pressures. ${ }^{124}$

\section{B Informed Consent}

LDT decision making, particularly where it involves a person of emotional value to the donor, challenges the concept of informed consent. Majeske, Parker and Frader state: ${ }^{125}$

The traditional requirements of informed consent do not appear well suited to evaluations of living related donors' decision making, however, with its frequent emphasis on feelings of relatedness, interconnectedness, and obligation- a sharp contrast to the unpressured, rational decision making typically said to underlie informed consent...The traditional model of informed consent is based on an impartialist understanding of the requirements of autonomy that de-emphasises personal relationships so that each decision maker is conceived as being free to pursue autonomous goals.

Donors engage in potentially damaging procedures to benefit others. As such, the ethic of care may be a more appropriate ethical framework than informed consent. A parent whose options are either the death of their child or consent to donation may feel there is no choice at all, yet parents donating to their children display the least ambivalence of all donors. ${ }^{126}$ Part of informed decision making is that the decision maker possesses the ability to delay impulses and to refrain from making a decision without reflection. ${ }^{127}$ Studies of live kidney donors have suggested they decide before inquiring into possible consequences to themselves, or seeking reassurance as to the eventual benefits for the recipient. ${ }^{128}$

Price argues that the lack of alternatives does not necessarily indicate that the consent was not voluntary, because when people suffer serious illnesses there often is only one realistic therapeutic option and the lack of alternatives does not invalidate the consent to that treatment. ${ }^{129}$ However, that argument overlooks the difference between consenting to treatment and consenting to a procedure that will benefit another, with no medical benefit.

\footnotetext{
${ }^{124}$ Such as transplantation physicians being willing to provide a medical "white lie” as to suitability of a donor who appears unwilling.

${ }^{125}$ R Majeske, L Parker and J Frader "In Search of an Ethical Framework for Consideration of Decisions Regarding Live Donation” in B Spielman (ed) Organ and Tissue Donation: Ethical Legal and Policy Issues (Southern Illinois University Press, Carbondale, 1997) 89, 95.

${ }^{126} \mathrm{R}$ Simmons and others Gift of Life: the Effects of Organ Transplantation on Individual, Family and Societal Dynamics (Transaction Books, New Brunswick, 1987) 189.

${ }^{127}$ I Janis and L Mann Decision Making: A Psychological Analysis of Conflict Choice and Commitment (The Free Press, New York, 1977) 11.

${ }^{128} \mathrm{R}$ Simmons and others, above, 189. Only 25 per cent of the donors could be regarded as complying to any substantial degree with a deliberative model of decision making.

${ }^{129}$ David Price Legal and Ethical Aspects of Organ Transplantation (Cambridge University Press, Cambridge, 2000) 294.
} 
Commentators distinguish between internal and external pressures that might compel a choice to consent to donation. ${ }^{130}$ Internal pressures are feelings of obligation and compulsion, resulting from the nature of the relationship. External pressures are those from outside agencies such as family members, medical professionals and the knowledge of the low likelihood of the patient receiving a donor organ. Faden and Beauchamp assert that pressure will be insufficient to nullify free consent, unless it has overborne the will of the person consenting, rather than having the effect of encouraging the donor to make the decision that they would have made in any event. ${ }^{131}$

\section{Compulsion}

The concept of an ethic of care and decision making within relationships and the community has not compelled donation, even where it involves little personal risk or inconvenience. This is because people have ultimate dispositive power over their body parts. In McFall $v$ Shimp ${ }^{132}$ the Court refused to order a man to donate compatible bone marrow to his cousin to save the cousin's life: ${ }^{133}$

\section{[T]o compel the defendant to submit to an intrusion to his body would change every concept and principle upon which our society is founded. To do so would defeat the sanctity of the individual and would impose a rule which would know no limits and one could not imagine where the line would be drawn.}

Although, the Court described the refusal as morally indefensible, ${ }^{134}$ the general view is that donation displays moral goodness, not moral duty. Compulsion would involve practical problems of enforcement and the risk of loss of trust in the medical profession. Although compulsory acquisition of other types of property exists, ${ }^{135}$ it is not recommended with regard to body parts.

\section{Ethical Aspects}

From a consequentialist perspective, LDT is a "good", especially kidney donation, as the outcomes are extremely good balanced against very low risk to donors. This perspective is also consistent with a beneficence-based ethic. The Nuffield Council considered that there was no ethical injury arising from LDT. ${ }^{136}$ Deontological approaches emphasise the right of individuals to control the uses of their body, irrespective of the likely benefit to be derived by, or denied to, another.

The principle of non-maleficence is problematic in this context, because all organ removals are potentially harmful and it is difficult to weigh the benefits to the

\footnotetext{
${ }^{130}$ R Majeske, L Parker and J Frader "In Search of an Ethical Framework for Consideration of Decisions Regarding Live Donation” in B Spielman (ed) Organ and Tissue Donation: Ethical Legal and Policy Issues (Southern Illinois University Press, Carbondale, 1997) 89, 94.

${ }^{131}$ Ruth M Faden and Tom L Beauchamp A History and Theory of Informed Consent (Oxford University Press, Oxford, 1986) 345.

${ }^{132}$ McFall v Shimp (1978) No 78-17711 10 Pa (1978) D\&C 3d 90 (Pa). See also F Huffman "Coerced Donation of Body Tissues: Can we live with McFall v Shimp?” (1979) 40 Ohio State L J 409.

${ }^{133}$ McFall v Shimp (1978) D\&C 3d 90, 91 (Pa) Flaherty J.

${ }^{134}$ McFall $v$ Shimp, above, 91 Flaherty J.

${ }^{135}$ As in the Public Works Act 1981.

${ }^{136}$ Nuffield Council on Bioethics Human Tissue: Ethical and Legal Issues (Nuffield Council on Bioethics, 1995) <http://www.nuffieldbioethics.org> (last accessed 22 December 2004).
} 
recipient against the risk to the donor. There are short-term risks resulting from the donation and any long-term risks are unknown. As stated by Price: ${ }^{137}$

It is necessary to accept that harms are indeed intentionally inflicted and that it is the willingness of the individual to consent to that harm and the potential benefits accruing to others (and also donors) which ultimately justify any particular procedure.

The justification for LDT rests with donors' interests in their body parts and the right of self-determination, together with beneficence. There may be limits to the scope of permitted donations and persons may be prevented from giving autonomous consent to such procedures when harm rises above a certain level. However, Alldridge rejects a threshold approach, or any ceiling on permissible risk taking. ${ }^{138}$ Similarly, Harris states: ${ }^{139}$

Should I be permitted voluntarily to donate a vital organ like the heart? Again, if I know what I am doing then I do not see why I should not give my life to save that of another if that is what I want to do.

Price states: ${ }^{140}$

The unique nature of LDT creates a challenge for orthodox analysis and development of an adequate regulatory infrastructure. The prima facie clash between the interests of the potential donor and those of the intended recipient requires accommodation and resolution.

The Law Commission of Canada asserted that, in the context of LDT: "Consent alone...does not ensure the moral acceptability of the medical intervention." 141 In most surgical operations, the person may consent to substantial harm with the purpose of therapeutic benefit, but it is more problematic to justify such harm when the procedure is non-therapeutic.

The contentious issue is not freedom of choice, even though there is a risk of coercion. Rather, it is the potential to harm a healthy donor, because no one would consider such a choice coercive if no risk of harm were involved. Donors make decisions to donate within a web of social relationships and most people feel more comfortable about LDT between family members, particularly if a child is the recipient. The assumption is that this is a gift of love, which is viewed differently from endorsing self-harm from a stranger. If a parent decides to donate to save their dying child, this is not a purely other-regarding decision. Potentially, the parent will receive a substantial benefit, with extended ramifications for the whole family unit.

\footnotetext{
${ }^{137}$ David Price Legal and Ethical Aspects of Organ Transplantation (Cambridge University Press, Cambridge, 2000) 227 (emphasis in the original).

${ }^{138}$ P Alldridge “Consent to Medical and Surgical Treatment- The Law Commission’s Recommendations” (1996) 4 Med L Rev 129, 143.

139 John Harris Wonderwoman and Superman: the Ethics of Human Biotechnology (Oxford University Press, New York, 1992) 113.

${ }^{140}$ David Price Legal and Ethical Aspects of Organ Transplantation (Cambridge University Press, Cambridge, 2000) 228.

${ }^{141}$ Law Reform Commission of Canada Procurement and Transfer of Human Tissues and Organs Working Paper 66 (Ministry of Supply and Services, Ottawa, 1992) 7.
} 

LDT: ${ }^{142}$

The Law Reform Commission of Canada proposed three conditions for

- $\quad$ The donor must consent freely and knowledgably;

- $\quad$ There must be some reasonably expected benefit to the donor; and

- $\quad$ Likely benefits to the recipient must considerably outweigh likely harms to the donor.

Price comments that: "These conditions attempt to reconcile the three key operational ethical principles here: (donor) autonomy, non-maleficence (to the donor) and beneficence (for the recipient). ${ }^{143}$ He suggests that an assessment of benefit to the donor is not required as a precondition for competent adult donors, as it is subsumed within the requirement of informed consent and states that so long as an initial risk/benefit assessment is satisfied, then the donor should decide whether to donate. ${ }^{144}$ The Task Force on Organ Transplantation stated: ${ }^{145}$

Refusing to use a kidney from a competent living donor is unduly paternalistic where a donor is well informed, understands, and is willing to accept the risks of kidney donation.

However, the physician should have the right to decline to perform the transplant if to do so would be incompatible with acceptable medical practice. ${ }^{146}$ If there is objective evidence of the existence of pressure, so the genuineness of consent is in doubt, the doctor may have a duty to decline to proceed.

LDT has advantages over cadaveric donation. It is possible to be confident that the donor has actually given informed consent, with no need to resort to stratagems such as presumed consent. The donors are able to appreciate the benefits of their altruism. Living donors are, potentially, much more plentiful than suitable cadavers and cadaveric donations are unlikely to suffice to meet the need, no matter what strategies are employed to increase the rates of donation.

LDT is a societal good, so donors should receive compensation for resultant expenses, such as loss of income during pre-operative procedures and convalescence, travel and accommodation costs, home help, childcare and a guarantee that any future medical treatment consequent upon the donation should be state-funded and high priority. The funding for compensation payments should not come from the recipient, but from the state. ${ }^{147}$

A vocabulary of rights and autonomy, or reliance on property interests, is inadequate to represent the intimate bonds of family and friends, the balance between

\footnotetext{
${ }^{142}$ Law Reform Commission of Canada, above, 48.

${ }^{143}$ David Price Legal and Ethical Aspects of Organ Donation (Cambridge University Press, Cambridge, 2000) 253.

${ }^{144}$ Price, above, 258.

${ }^{145}$ United States Department of Health and Human Services Report of the Task Force on Organ Transplantation: Issues and Recommendations (United States Department of Health and Human Services, Washington DC, 1986) 37.

${ }^{146}$ J Childress Who Should Decide? Paternalism in Health Care (Oxford University Press, New York, 1982) 3.

${ }^{147}$ See the 2005 decision to compensate donors, discussed in chapter 8.
} 
sacrifice and self interest and the complex relationship between doctors and organ donors. In a moral framework shaped by respect for patient autonomy, the decision whether or not to undergo risk or harm can seem a matter purely for the donor to make.

This thesis argues that although this is an area where it could be ethically justifiable to restrict the free alienation of the property interest, the law is largely unable to ensure the voluntariness of decision making, apart from establishing procedural criteria, such as a right to withdraw. Rather than regulation limiting LDT, it is better to establish transparent procedures for the counselling and consent processes, together with reliance on the professionalism of medical professionals, who should decline to proceed where there is apparent reluctance to donate. ${ }^{148}$ The UKHTA provides that living organ donation is illegal, unless regulations permit it to take place and case-by-case approval of Human Tissue Authority is obtained. ${ }^{149}$ Such a restriction is not recommended, as it does not appear necessary in light of the lack of evidence of egregious practices in this area. However, it is recommended that the Authority be required to establish guidelines, if necessary. ${ }^{150}$

\section{CONCLUSIONS}

\section{A Biological Samples}

The body is more than a utilitarian object, as it has social and ritual significance, with cultural meanings and personal associations. It is the only thing many people can really call their own. ${ }^{151}$ The use of body parts saves lives and contributes to scientific research, but it also intrudes on body boundaries and personal autonomy. The range of potential uses of body parts and their value are increasing, whilst their status remains uncertain. A framework to resolve these issues must protect the interest persons have in their own bodies, in light of the increasing value of body materials. It must also be consistent, fair and practical in its application.

The recognition of property rights has implications for access, storage and use of human biological samples. This issue has been considered infrequently by the courts and the cases have only dealt with limited fact situations. The status of excised body parts is inconsistent, reflecting little conceptual coherence. The cases considered in this chapter reveal three themes:

- An unwillingness to acknowledge that sources have property interests in excised body parts;

- $\quad$ A lack of consensus about the appropriate ethical basis for the retention and use of body parts; and

\footnotetext{
${ }^{148}$ Doctors commonly provide a "white lie" regarding unsuitability to donate, where reluctance is evident.

${ }^{149}$ Human Tissue Act 2004 (UK), s 33.

${ }^{150}$ See the discussion in chapter 8.

${ }^{151}$ Leonard Barkan "Cosmos and Damian: Of Medicine, Miracles, and the Economics of the Body" in Stuart Younger, Renee Fox and Lawrence O’Connell (eds) Organ Transplantation: Meanings and Realities (University of Wisconsin Press, Madison, 1977) 242, 246.
} 
- $\quad$ The need to develop a uniform standard in the treatment of human body materials, in light of the rapid development in biotechnology.

The courts have not produced any clear ruling on the particular property rights that may be held over tissue samples, beyond a right of possession, the violation of which constitutes theft only in limited circumstances. It is not clear what other property rights exist, although the common law has implicitly accepted the existence of other property rights in tissue, such as the right to use, by allowing continued possession by hospitals, laboratories and museums. Boulier suggests that: "Once again, the law is lagging behind medical technology, though perhaps it is seeking to abandon the no property rule by inaction."152

Essentially, the framework needs to ensure that donors are able, if they wish, to retain a continuing relationship with their excised body parts after consent has been given. This thesis suggests that a body part is property at the point of severance, as it no longer forms a functional unity with the entire body. At that point, it is the property of the source and may be transferred to another. If a fully informed source fails to assert the rights of ownership, possession or control, it can be inferred that there is an intention to abandon the material.

Researchers, or hospitals engaged in transplantation, obtain possessory rights akin to a bailment. The right to possess is only for specified purposes, and remedies should be available in the case of a breach. Once organs are transplanted into a recipient, they are incorporated that person's body and cease to be separate property.

If the purpose changes during the course of research, additional consent is required unless this was exempted in the initial consent. If such further consent was refused, the samples concerned should be returned or destroyed, and any information derived from the samples removed. Although this appears an onerous requirement, particularly where information from a large number of individuals is aggregated, it is achievable with the use of increasingly sophisticated computer systems, so long as appropriate records are maintained.

Commentators oppose property interests in the human body because of concerns about the sale of organs. ${ }^{153}$ However, commercialisation already exists, and bodies may produce returns to all parties, other than the source. In Moore, ${ }^{154}$ the California Supreme Court stated that Moore's ownership claim was problematic because the law "limits drastically a patient's control over excised cells" and "eliminated so many of the rights ordinarily attached to property that... what [was] left [could not be assumed to] amount to "property" or "ownership for the purposes of the common law." "Moore suggests that the user of tissue acquires possessory rights at least, and probably a right of ownership, but the source does not. However, not all of the incidents of property need be present for the assertion of ownership

\footnotetext{
${ }^{152}$ William Boulier "Sperm, Spleens and Other Valuables: The Need to Recognize Property Rights in Human Body Parts” (1993) 23 HOSTRA L Rev 693, 715.

${ }^{153}$ See the discussion in chapter 1.

${ }_{154}$ Moore v Regents of the University of California (1990) 51 Cal 3d 120, 140 (Sup Ct Cal) Panelli J.

${ }^{155}$ Moore v Regents of the University of California, above, 176 Mosk J.
} 
rights. ${ }^{156}$ Property rights and market alienability are not synonymous, so it is possible to have a property right without the right to buy or sell the goods.

The positive functions of control of a living person's excised body parts are to serve the person's interests as a human being, paying due regard to autonomy and confidentiality and to relate the means of acquisition to the uses that can be made of the material, subject to the constraints of societal approval and public policy. Negatively, the function of control is to give the source of the material preventive or remedial power over detrimental use of the body materials. By denying the property interest of the human source, that person is prevented from asserting that the materials have been stolen or converted.

Should a discovery result in commercial benefit, sources should either be entitled to a share in the resultant profits, or be paid a negotiated figure to abandon their rights. The great bulk of the value of a patent, such as a cell-line patent and the derivative products, can be attributed to the efforts of the researchers and drug companies, rather than the "raw materials" from the sources, and so it is reasonable to limit the level of payment. This could be determined by individual negotiation, but a more practical approach would be to make provision for the Human Tissue Authority to negotiate collectively, to avoid multiple negotiations. ${ }^{157}$

In some cases, the motivation of the sources is to enable predictive tests to be publicly available. Researchers should not be able to obtain a patent without the knowledge of the sources, who should be able to place conditions on their consent, such as preventing the licensing of tests, or that some or all of the subsequent profits must be employed to advance research, rather than become profit for biotechnology companies. ${ }^{158}$ The model demonstrated by PXE International may be appropriate where there are well-organised patient groups, but many sources may not be in a position to negotiate such an agreement. However, as such direct links with a patented product are rare, there seems little need for legislation in this area. The guidelines for ethics committee oversight of research proposals should include a requirement to ensure that researchers who anticipate a commercial product inform the donors of this and advise them to seek advice to protect their interests. ${ }^{159}$

\section{B Living Donor Transplantation}

Property in severed organs should remain with the person from whom the materials were removed, until corporeal reintegration occurs in the recipient. Doctors and hospitals having control of the materials would have possessory rights only, subject to the conditions imposed in the donor's consent. The hospital or surgeon obtaining physical possession would be a bailee, with a duty to take reasonable care of the property. Thus, a failure to comply with the terms of the bailment, such as unauthorised transplantation, might constitute theft and negligent misuse might amount to unlawful conversion.

\footnotetext{
${ }^{156}$ J E Penner “The ‘Bundle of Rights’ Picture of Property” (1996) 43 UCLA L Rev 711, 712.

157 See the discussion in chapters 7 and 8.

158 See the discussion in chapter 7.

159 See the discussion in chapter 7.
} 
In order to safeguard against coercion or commercialisation, neither recipients nor their medical advisors should solicit organ donors. The process should continue to be managed through independent third party agencies, with oversight by the Human Tissue Authority. The apparent existence of voluntary and informed consent should be verified for both related and unrelated donors, recognising the potential for an ethic of care model to create its own form of tyranny, in which the relationship itself implies a duty to donate. 


\section{Chapter 4}

\section{PERSONHOOD}

\section{INTRODUCTION}

Policies about uses of human body parts are influenced by perspectives of the significance of embodiment, the concept of self, and how parts of the body relate to the whole. These depend on whether a dualist or monalist perception of the "self" and the body is accepted. The dualist perception is that the body is separate from the self, thus the continued functioning of the body is not morally significant, so death may be declared even though the lower brain and vegetative functions persist. The monalist perspective is that the body forms part of the self, so its continuing function is incompatible with death.

In light of the intention in this thesis to incorporate a property construct into a legislative framework, it is necessary to consider the points at which personhood arises and concludes. There is potential for substantial effects on human rights if the meanings of "life" and "person" are capable of radical revision in the context of medical technologies with the ability to attenuate existence. The transplant community seeks ways to increase the number of available organs, and people in states between life and death may be medically suitable sources of body parts. If they are no longer "persons", then harvesting of parts from them is ethically acceptable. If the person is dead, although the body still lives, then the proposed framework suggests that the property interest in the body has passed to the representative, who may authorise the collection of body parts. While the source is still alive, non paired organs remain part of the source and cannot be harvested.

Ethical and legal "harm" in relation to insentient beings, and the moral significance of personhood are essential concepts in this thesis. They lead to consideration whether deontological concerns are raised by procedures intended to benefit others, which are not of direct benefit to the source. If no such concerns arise, utilitarian considerations may justify such procedures. Public policy must mediate between the utilitarian goals of increasing organ supply and facilitating potentially valuable research and deontological concerns around respect for persons. For example, potentially valuable treatments may result from stem cell research using human embryos. Often these are "surplus" embryos that were produced for in vitro fertilisation. Their destruction raises ethical concerns, which are often expressed in terms of personhood.

This chapter will consider circumstances in which the concept of personhood is uncertain in order to define the parameters of the framework proposed in the thesis. Issues discussed include whether embryos are persons, with property rights over their cells or property, subject to proprietary rights of others. It also considers the point at the end of life when personhood ceases and property in the dead body would pass to the deceased's representative. Although it is accepted that non-paired organs can only 
be retrieved from dead donors, there are a variety of constructs of death, so the concept and criticisms of brain death are discussed.

\section{THE CONCEPT OF A PERSON}

Traditional medical ethics subscribe to the principle of the sanctity of human life in asserting that, because all lives are intrinsically valuable, it is wrong to intentionally kill a human being. However, technology now permits the maintenance of life by artificial means in persons who formerly would have died. Additionally, there has been substantial debate about the meaning of death- is it the cessation of the heartbeat and circulation, or is it the destruction of the upper brain, consisting of the cerebral hemispheres that contain the neuro-physiological basis of higher mental functions such as self-consciousness, deliberation, thought, memory and consciousness? The destruction of the upper brain means the loss of the capacity for any sort of mental life. It contains the basis of specific memories, beliefs, attitudes and personality traits that make up a person, so its destruction destroys the states that underlie personal identity. However, provided that the lower brain continues to function, the person will still live, as the lower brain (or brain stem) controls life processes such as respiration.

The point at which an individual ceases to be a person, or whether some individuals are ever persons at all, depends on the viewpoint of the commentator. Some employ mentalist personhood perspectives and regard the mind as being the critical entity, distinct from matter in the form of the human body. Others regard the mind as located within the body, or dependent upon the body. Those who regard the biological functioning of the body as being of paramount importance might regard the mind as either being distinct from the body or part of it. Gervais states: ${ }^{1}$

Underlying these different analytical approaches is a fundamental difference in focus- either on the human as organism or on the human as person.

The Law Reform Commission of Canada observed that: ${ }^{2}$

A conception of persons as embodied selves may not be amenable to rational justifications, because the respect it accords the body likely derives from fundamental sentiments that transcend rational argument.

Locke stated: ${ }^{3}$

...we must consider what person stands for; which I think, is a thinking intelligent being, that has reason and reflection, and can consider itself, the same thinking thing, in different times and places; which it does only by that consciousness which is inseparable from thinking and seems to me essential to it; it being impossible for any one to perceive without perceiving that he does perceive.

The extent to which the "self" is identifiable with the body is variable and, to some extent, dependent upon cultural or religious belief. However, the public

\footnotetext{
${ }^{1}$ K Gervais Redefining Death (Yale University Press, New Haven, 1986) 20.

${ }^{2}$ Law Reform Commission of Canada Procurement and Transfer of Human Tissue and Organs

Working Paper 66 (Minister of Supply and Services, Ottawa, 1992) 105.

${ }^{3}$ John Locke An Essay Concerning Human Understanding Book II (Oxford University Press, London, 1964) ch 27 (emphasis in the original).
} 
perception is that there is a strong correlation between the two, even continuing after death. Consequently, there is a lack of acceptance of the notion of self being related solely to mental and psychosocial functioning. In 1981, Scott expressed the view that once the shock of a new technology wears off, society adjusts by shifting its values if sufficient benefit is found to result. In referring to organ transplants from cadavers, he stated that " $[\mathrm{w}] \mathrm{e}$ are dealing with deep-rooted attitudes and nothing more, attitudes which are in fact changing." 4 However, it is debateable whether efforts to reconceptualise the body as distinct from the person inhabiting it would ever be able to overcome a cultural insistence on self/body inviolability.

Harris states the issue as when life begins and ceases to matter morally. ${ }^{5} \mathrm{He}$ asks: "In short, when does life begin to have that special value we believe attaches to human life and when does it cease to have that value?" 6 He argues that the value is the capacity to value life. In order to value its own life, a being would have to be aware that it has a life to value, which is similar to Locke's conception of selfconsciousness. This is an awareness of awareness. The being would have to have a capacity to envisage the future and have a desire either to experience it or not. On such a view, permanently insentient individuals possess no interests. Harris also argues that because each person's life is individually valuable, two lives are more valuable than one. Consequently, if a choice has to be made between lives, where not all at risk can be saved, the choice should be to save as many lives as possible. ${ }^{7}$

Similarly, Tooley argues that personhood does not arise from belonging to a species whose normal adult members are persons, because an entity's moral status should be based on its intrinsic properties, rather than on its relations to other individuals. ${ }^{8}$ He states that moral status should be connected with having interests that need to be protected. The morally significant concept of an interest is one that connects with being a conscious being capable of having desires. A person whose upper brain has been destroyed does not have the same moral status as a person, so there is no moral reason to prolong the lives of such individuals.

This approach is opposed by Keown, who states: ${ }^{9}$

The law does not deny personhood, and the rights it attracts, because the person has lost the ability to think even though the necessary legal respect may vary from one context to another.

Lamb argues that personal identity is a quality of a living thing, not a reference to an individual's physical state or structure. ${ }^{10}$ He claims that there is insufficient diagnostic accuracy of personhood to use it as a test to determine when actions such as organ retrieval may take place.

\footnotetext{
${ }^{4}$ Russell Scott The Body as Property (Viking Press, New York, 1981) 260.

${ }^{5}$ John Harris The Value of Life: An Introduction to Medical Ethics (Butler \& Tanner Ltd, London, 1985) 8.

${ }^{6}$ Harris, above, 8.

${ }^{7}$ Harris, above, 22.

${ }^{8}$ Michael Tooley "Personhood" in Helga Kuhse and Peter Singer (eds) A Companion to Bioethics (Blackwell Publishers Ltd, Oxford, 1998)123, 123.

9 J Keown "Restoring Moral and Intellectual Shape to the Law after Bland" (1997) 113 LLQR 481, 493.

${ }^{10}$ David Lamb Organ Transplants and Ethics (Routledge, London, 1990) 43.
} 
The rationale behind the requirement that the donor be dead before non-paired organs are harvested is to ensure respect for persons, and this is accomplished by ensuring that the ends or interests of potential donors are not threatened. ${ }^{11}$ If people who permanently lack awareness lack any interests at all, the dead donor rule would not apply to them. Alternatively, the person lacks awareness of interests so cannot be harmed by an event of which they have no knowledge. This is a contentious view, especially to people who believe that there are innate interests.

Personhood arguments can be challenged on both deontological and utilitarian grounds. Kant argued that all human beings have intrinsic worth, rather than instrumental worth. To argue that some humans are not persons, and so may be used to benefit others, transgresses the second form of Kant's categorical imperative: “Act so you treat humanity, whether in your own person or in that of another, always as an end and never as a means only."12

From a utilitarian viewpoint, the use of insentient beings as a means to benefit others may lower respect for the value and dignity of human life and reduce public trust in medical decision making, resulting in an overall reduction in willingness to participate in research, or donate organs. The crucial decision may not be whether to respect the sanctity of life, but which decision best respects it.

The resolution of these issues in the form of, or even in the absence of, law demonstrates the relationship between law and morality in that society. Developments depend on whether that state wishes to impose views on citizens relating to moral convictions, and the social acceptability of such views. In making such decisions, the Courts and legislature are compelled to develop a social and, at times, a moral vision of relationships and medical treatment in order to determine considered responses to the social and moral dilemmas created by modern biotechnology. New definitions of death challenge familiar assumptions and, this regard, the courts have tended towards pragmatism, rather than adopting a philosophical concept of a "person."

\section{AIREDALE NHS TRUST V BLAND ${ }^{13}$}

Bland had been in a persistent vegetative state (PVS) for three years when a doctor and the Trust responsible for his care, with the support of Bland's family, successfully applied to the High Court for a declaration that it would be lawful to remove his naso-gastric tube, resulting in his death by dehydration. It was held that the law of homicide did not cover the proposed course of conduct, the declarations were granted and Bland died.

Nine judges in three courts pronounced on the case and each made it clear that, although Bland was alive, they did not value life that is only human in a

\footnotetext{
11 N Fost “The Unimportance of Death” in S J Youngner, R M Arnold and R Shapiro (eds) The Definition of Death: Contemporary Controversies (The John Hopkins Press, Baltimore, 1999) 16178.

12 I Kant Fundamental Principles of the Metaphysics of Morals T Abbott (trans) (Bobbs Merrill Co Inc, Indianapolis, 1946) 46.

${ }^{13}$ Airedale NHS Trust v Bland [1993] 1 AC 789 (HL) Keith, Goff, Lowry, Browne-Wilkinson and Mustill JJ.
} 
biological sense. The implication is that Bland was in some hinterland between life and death, a kind of "living death."

Goff LJ cited with approval the decision of Thomas J in Auckland Area Health Board $v A-G,{ }^{14}$ where it was held that it was not unlawful to discontinue ventilation of a patient with Guillain-Barré syndrome, if that accorded with good medical practice. ${ }^{15}$ This amounted to a collegiate decision made by the doctors, endorsed by the appropriate ethics committee, with the informed consent of the family members concerned. It was held that the sanctity of life is not an absolute value. It could be offset by values of human dignity and personal privacy. ${ }^{16}$

Bland $^{17}$ supports the notion that body parts are separate from the person and distinct from the "self". Thus, there is no ethical objection to a person specifying by way of an advance directive that, in certain circumstances, steps should be taken to preserve body parts. Withdrawal of hydration renders them unfit for transplantation. Whilst euthanasia is beyond the scope of this thesis, it is suggested that a person might instruct that withdrawal of treatment must be carried out in a manner that best protects the organs, as is done when a brain dead person is withdrawn from ventilation.

\section{THE STATUS OF GAMETES AND THE UNBORN CHILD}

\section{A Gametes}

The preservation, and subsequent use, of gametes illustrates the need for a coherent legal framework, as categorisation of the materials is integral to resolution of disputes. The cases considered in this section are responses to the different factual situations in different jurisdictions yet, generally, the approach is to ensure that the prior interests of the deceased man are respected. They also lead to complex considerations of succession law.

A fundamental issue in posthumous reproduction is whether a man has the right to transfer or bequeath his sperm to another person. If sperm is not classified as some form of property, then a donor's interest in the sperm may die with him and make legal post-mortem insemination impossible. If stored gametes are property, it follows logically that they are owned, because someone has possession of them, or has the authority to decide what to do with them. Consequently, the owner has the power to bequeath them. Alternatively, they may be less than property, but in a category that entitles them to special respect, because of their potential for human life. The cases considered relate to sperm, but the ability to cryopreserve and subsequently use human eggs is presently being refined and this discussion would apply similarly to oocytes.

\footnotetext{
14 Auckland Area Health Board v Attorney-General [1993] 1 NZLR 235 (HC) Thomas J.

15 Bland, above, 867.

16 Auckland Area Health Board v A-G, above, 244, 245.

${ }^{17}$ Bland, above.
} 
In 1984, the French Tribunal decided Parpalaix $v$ CECOS. ${ }^{18}$ Alain Parpalaix was diagnosed with testicular cancer and, as chemotherapy would leave him sterile, he deposited sperm in a sperm bank. He did not state his intentions for the frozen sperm in the event of his death. He married two days before his death. When his wife, Corinne, subsequently requested the sperm for use in artificial insemination, this was refused. Alain's wife and parents claimed that they were his heirs and the owners of the sperm. They argued that Alain's intent was for Corinne to use the sperm to conceive a child after his death.

The sperm bank argued that they did not have any obligations to Corinne, as their agreement was with Alain and that the sperm was not divisible from the body in the absence of specific instructions from Alain, and so was not inheritable. Since Alain and Corinne were not married at the time of deposit and Alain did not provide any written directives, the sperm should not be given to Corinne. Their final argument was that the deposit was for therapeutic purposes, to psychologically aid Alain.

The Court found that human sperm was not inheritable property within the meaning of the French Civil Code and that Alain's intent was the determining factor. As he had not specified his intent in writing, his parents and Corinne were best able to articulate it. The Tribunal ordered the return of the sperm to Corinne, but she was unsuccessful in her attempt to posthumously bear Alain's child.

In 1993, the first United States case arose relating to the bequeathing of frozen sperm. ${ }^{19}$ Kane lived with Hecht and had two teenaged children from a previous marriage. Before committing suicide, he deposited sperm at a sperm bank, signing an agreement containing the statement "in the event of the death of the client...the client instructs the Cryobank to....continue to store [the specimens] upon request of the executor of the estate [or] release the specimens to the executor of the estate." ${ }^{20}$ Kane stated that the vials were to be released to Hecht and her physician. His will named Hecht as executor and bequeathed all right, title, and interests in any stored sperm to her. He left a letter addressed to his children, including future posthumous offspring. Kane's children challenged the will and argued that Moore ${ }^{21}$ applied, resulting in a no-property conclusion. The Court held that he had "an interest in the nature of ownership, to the extent that he ha[d] decision-making authority as to the use of his sperm for reproduction." ${ }^{22}$ Hecht established that gametes are a unique type of property, but the court avoided adopting a full property analogy.

In Hall v Fertility Institute of New Orleans, ${ }^{23}$ Hall was diagnosed with cancer. He deposited 15 vials of sperm with a fertility institute and executed a formal act of donation, by which he transferred his interest in the vials to his girlfriend. Following Hall's death, his executor sought to have the vials destroyed or transferred to Hall's son, because of the son's discomfort at the prospect of posthumous siblings. The

\footnotetext{
${ }^{18}$ Parpalaix v CECOS as related in C L Streeb “A Child Conceived After his Father's Death?: Posthumous Reproduction and Inheritance Rights. An Analysis of Ohio Statutes” (2000) 48 Clev St L Rev 137, 149.

${ }^{19}$ Hecht v Superior Court (1993) 20 Cal Rptr 2d 275 (Ct App).

${ }^{20}$ Hecht $v$ Superior Court, above, 276.

${ }^{21}$ Moore v Regents of the University of California (1990) 793 P 2d 479 (Sup Ct Cal). See the discussion in chapter 3.

${ }^{22}$ Moore $v$ Regents of the University of California, above, 283.

${ }^{23}$ Hall v Fertility Institute of New Orleans (1994) 647 So 2d 1348 (La Ct App).
} 
executor unsuccessfully alleged that the transfer of sperm was contrary to public policy and morals. It was held that, if the facts at trial showed that the decedent was competent at the time of the gift and not under undue influence, the frozen semen was the property of the girlfriend and she had full rights to its disposition. Similarly, in Kurchner v State Farm Fire and Casualty Co, ${ }^{24}$ Ramirez J held that sperm outside of the body is property and not a part of the body, thus, no bodily injury was caused by the destruction of stored sperm.

In the United Kingdom, in $R v$ Human Fertilisation and Embryology Authority ex $p$ Blood, ${ }^{25}$ Blood contracted meningitis and fell into a coma. Shortly before his death, semen was collected, following a request by his wife. Brown J held that the Authority was correct to refuse to allow her to use the semen, because her husband had not given consent to its storage before he died and it had not exceeded its powers by refusing to allow her to take the semen overseas. This latter finding was reversed by the Court of Appeal, because the Authority had not taken into consideration the effect of the European Community Treaty. The Court left open the question of the lawfulness of the taking of sperm from an unconscious person. ${ }^{26}$

In New Zealand, the Ministerial Committee on Assisted Reproduction Technologies, when considering the status of gametes and embryos, stated that the property approach failed to give due regard to the mana of human tissue and the personhood approach was inconsistent with present abortion laws. The committee did not resolve the issue of status, but felt that the powers of disposition should rest with the providers of the gametes and that the first point of reference should be the contract between the clinic or storage agency and the donor. ${ }^{27}$

Similarly, the Guidelines for the Storage, Use, and Disposal of Sperm from a Deceased Man $^{28}$ provide that appropriate counselling must be provided to men donating sperm and consent forms must specify what is to happen to the sperm, should the donor die leaving stored sperm. In the case of sperm stored prior to medical treatments, options on the consent form must provide either that the sperm is disposed of in a culturally respectful manner, or that it will be available for use by a specified person within a specified time frame. When consent cannot be obtained, or there is a variation to the requirements of the guidelines, an application for ethical review must be submitted to the ethics committee. The guidelines state that the collection of sperm from a comatose or recently deceased man, without his prior written consent, is "ethically unacceptable.",29

The Code provides for surrogate consent on behalf of incompetent persons and that "[e]very consumer may use an advance directive in accordance with the common

\footnotetext{
${ }^{24}$ Kurchner v State Farm Fire and Casualty Co (2003) 858 So 2d 1220, 1221 (Fla Ct App).

${ }^{25} R$ v Human Fertilisation and Embryology Authority ex p Blood [1997] 2 FLR 756 (CA) Lord Woolf MR, Waite, Henry LJJ. Mrs Blood succeeded in giving birth to her husband's posthumous children.

${ }^{26} R$ v Human Fertilisation and Embryology Authority ex p Blood, above, 764.

${ }^{27}$ Ministerial Committee on Assisted Reproduction Technologies Assisted Human Reproduction: Navigating Our Future (Department of Justice, Wellington, 1994) 93.

${ }^{28}$ National Ethics Committee on Assisted Human Reproduction Guidelines for the Storage, Use, and Disposal of Sperm from a Deceased Man (Ministry of Health, Wellington, 2000).

${ }^{29}$ The guidelines have been adopted as an established procedure under the Human Assisted Reproductive Technology Act 2004: Human Assisted Reproductive Technology Act 2004, s 14 (1)(a)these guidelines must be reviewed by November 2007.
} 
law.”30 Advance directives are not required to be in writing, therefore a conflict might arise between the Code and the Guidelines if a man has clearly indicated his wishes with respect to the collection or disposition of semen, but this has not been expressed in writing, perhaps because of the sudden nature of his illness. Presumably, collection would take place, and use after the man's death would be considered by the ethics committee.

By contrast, in October 2003, in response to several such applications in Israeli courts, the Israeli Attorney-General published guidelines that allow courts to permit the posthumous extraction and use of sperm. ${ }^{31}$ The guidelines are based on the assumption of presumed consent, in the absence of explicit objection by the deceased man. This is justified by balancing the uncertain interests of the deceased against the certain expressed interests of the spouse. Her interests are considered strong enough to limit state curtailment of her reproductive autonomy. Approval is limited to female partners at the time of death and denied to other parties, such as parents. The guidelines argue that fatherhood is not being forced on the man, even should a mistake have been made about his wishes. The child would be registered as the child of the deceased, but such registration does not entail any inheritance rights. Ravitsky suggests that the guidelines reflect the strong pro-natalist cultural values dominant in Israel and the primacy given to honouring the memory of the dead. ${ }^{32}$

One problem from posthumous reproduction is the distribution of the donor's estate. If potential children can be beneficiaries, administration may be delayed for years until the children are born. During that time, other beneficiaries would be left waiting and uncertain about their futures. Since public policy would suggest the desirability of efficient distribution of estates, the law is unlikely to permit potential children to inherit, without some time limitations.

The status of gametes indicates the challenge to established social structures imposed by such technologies and the effect they may have on traditional views of inheritance and the family. It also demonstrates the conceptual incoherence of the law. Gametes are treated as property in almost all respects, yet there is a marked reluctance to acknowledge this. Similar issues could arise if one of the gamete sources wished to utilise stored embryos after the death of one of them. ${ }^{33}$

\section{B Is An Unborn Child a Person?}

\footnotetext{
${ }^{30}$ Code of Health and Disability Services Consumers’ Rights, Right $5<$ http://www.hdc.org.nz> (last accessed 14 September 2006).

${ }^{31}$ Vardit Ravitsky "Posthumous Reproduction Guidelines in Israel” (2004) Hastings cent rep 6.

${ }^{32}$ Ravitsky, above, 7. See also Barbara Prainsack “'Negotiating Life’: The Regulation of Human

Cloning and Embryonic Stem Cell Research in Israel” (2006) 36 Social Studies of Science 173, 185.

${ }^{33}$ See the discussion about embryos, below.
} 
A child is born when its body has been completely removed from the body of the mother, even though it might still be attached by the umbilical cord. ${ }^{34}$ A spatial relationship between the bodies is necessary. Additionally, the child must be born "alive". In $C \vee S,{ }^{35}$ the Court of Appeal held that, in order to be born alive, a child must be able to breathe. If a child requires mechanically assisted breathing support, it is born alive if it will eventually be able to breathe unaided. In Rance v Mid-Downs Health Authority, ${ }^{36}$ a child was held to be born alive if it was capable of breathing through its lungs alone, without deriving any support from its mother. The Court did not require the child to be viable, partially because of doubt about the meaning of that term.

The classical common law position adopted by the English law was that a foetus is not a person. ${ }^{37}$ Although the child en ventre sa mère has some protected interests, such as the right to inherit, such interests are contingent rights that crystallise only on birth alive. The Warnock Committee stated: ${ }^{38}$

\begin{abstract}
We examined the current position of the in vivo embryo in law. The human embryo per se has no legal status. It is not, under law in the United Kingdom, accorded the same status as a child or an adult, and the law does not treat the human embryo as having a right to life. However, there are certain statutory provisions that give some level of protection in certain respects.
\end{abstract}

In Burton $v$ Islington $H A,{ }^{39}$ a case relating to damage to a foetus in the womb, Dillon LJ held that the injury to the unborn child was just an evidentiary incident in the causation of damage suffered at birth. ${ }^{40}$ Subsequently, Mustill LJ stated that the relationship between the mother and her unborn child is one of bond, not identity, and that the Court of Appeal was wrong to treat the foetus as part of the mother, rather than a unique organism. ${ }^{41}$

In New Zealand, the parents of a still-born child made a claim for damages, ${ }^{42}$ claiming that the obstetrician failed to exercise reasonable care and skill and failed in his obligations of communication to them. The obstetrician asserted that the claims were statute-barred, ${ }^{43}$ because they related to damages arising directly or indirectly out of a personal injury. In the High Court, Wild and Ronald Young JJ held that, although an unborn child is "inside and connected to" the mother, it is not the same as the mother. ${ }^{44}$ While the foetus is connected to the mother and housed within her body

\footnotetext{
${ }^{34}$ Glanville Williams Textbook of Criminal Law (2 ed, Stevens, London, 1983) 289-290.

${ }^{35}$ C v S [1988] QB 135 (CA) Donaldson MR, Stephen Brown, Russell JJ.

${ }^{36}$ Rance v Mid- Downs Health Authority [1991] 1 QB 587 (QB) Brooke J.

${ }^{37}$ Paton $v$ Trustees of BPAS and another [1978] 2 All ER 987(CA); Re F (In Utero) [1988] 2 All ER 193 (CA); C v S [1987] 1 All ER 1230 (QB); [1988] QB 135 (CA).

${ }^{38}$ Warnock Committee Report of the Committee of Inquiry into Human Fertilisation and Embryology Cm 9314 (HMSO, London, 1984) para 11.16-17.

${ }^{39}$ Burton v Islington HA [1992] 3 All ER 820 (CA) Dillon, Balcombe and Leggatt LJJ.

${ }^{40}$ Burton v Islington HA, above, 839-40 Dillon LJ.

${ }^{41}$ Attorney General's Reference (No 3 of 1994) [1996] QB 581(HL) Goff, Mustill, Slynn, Hope, Clyde LJJ.

${ }^{42}$ Harrild v Director of Proceedings [2003] 3 NZLR 289 (CA) Elias CJ, Keith J, Blanchard J, McGrath J, Glazebrook J.

${ }^{43}$ Health and Disability Commissioner Act 1994, s 52(2).

${ }^{44}$ Harrild v Director of Proceedings [2002] NZAR 513 (HC) para 22.
} 
until birth, "none of this equates to sameness." 45 Harm to the unborn child is "distinct from harm to the mother" as a matter of "biological reality." 46

On appeal, Elias CJ stated: ${ }^{47}$

Foetus and mother are not the same but neither are they physically free from one another. They are physically connected. The connection ends with birth or by death of one of the two.

She and Keith $\mathrm{J}$ held that the mother did suffer a personal injury when her child died in utero. ${ }^{48}$ McGrath $\mathrm{J}$ held that the foetus cannot have any rights of its own until it is born and has a separate existence from the mother. He recognised that any conclusion that the mother and foetus are a single entity is problematic and stated that this is because the rule is based on expedience rather than principle. ${ }^{49}$ He held that a mother and foetus could consist of a single entity in a particular legislative context.

However, Blanchard and Glazebrook JJ held that to treat the death of the unborn child as direct physical injury to the mother is, in effect, to treat a mother and foetus as a single entity, which ignores biological reality. Their conclusion was that the death of the unborn child was the death of a separate organism, albeit one connected to the mother. ${ }^{50}$ Thus, the majority concluded that injury to the foetus is a personal injury to the mother, and so the statutory bar would apply.

In Sisasubramaniam $v$ Yarrall, ${ }^{51}$ although Heath $\mathrm{J}$ applied the majority decision in Harrild, he stated that he agreed with the dissenting judgments, that an injury to an unborn child should not be regarded as a personal injury suffered by the mother.

In Re an Unborn Child, ${ }^{52}$ it was planned that a pornographic film would include the birth of a child. Orders were sought, inter alia, placing the unborn child under the guardianship of the High Court. It was necessary to determine whether the term "child" included an unborn child. ${ }^{53}$ Heath $\mathrm{J}$ held that the issue was one of public policy $^{54}$ and "child" could include an unborn child for the purposes of making a guardianship order.

This decision raises a number of concerns. If an unborn child is a person, in this thesis would argue that it has a property interest in the excised parts of its body. It is difficult to determine the stage of development at which it would be treated as a

\footnotetext{
${ }^{45}$ Harrild $v$ Director of Proceedings, above, para 23.

${ }^{46}$ Harrild $v$ Director of Proceedings, above, paras 31-32.

${ }^{47}$ Harrild v Director of Proceedings [2003] 3 NZLR 289 (CA)[20].

${ }^{48}$ Harrild $v$ Director of Proceedings, above, [22] and[42].

${ }^{49}$ Harrild $v$ Director of Proceedings, above, [126].

${ }^{50}$ Harrild v Director of Proceedings, above, [69].

${ }^{51}$ Sisasubramaniam v Yarrall (21 December 2004) High Court Wellington CIV 2004-485-464, para 68 Heath J.

${ }^{52}$ Re an Unborn Child [2003] 1 NZLR 115 (HC) Heath J.

${ }^{53}$ Guardianship Act 1968, s 2(1).

${ }^{54}$ Re an Unborn Child, above, 117.
} 
person. ${ }^{55}$ Re an Unborn Child ${ }^{56}$ adopts a personhood approach, in order to justify controls over the behaviour of the mother. In light of the substantial ramifications should this case be applied universally to unborn children, it is likely that its application will be confined to its particular, highly unusual, factual situation. The practical difficulties arising from the personhood approach are so significant that this thesis argues that personhood only arises once a child is born alive. ${ }^{57}$

\section{Is An Unborn Child Property?}

An alternative approach is to argue that an unborn child is property and may be treated as a chattel. There has been reluctance to characterise embryos and foetuses as property, because this might lead to the notion that the owner could enjoy powers of sale, disposition, and bequest, and that such property might become the subject of property disputes, especially relating to relationship property. However, surplus embryos may be destroyed, ${ }^{58}$ donated to others or donated for research. The existence of a property interest is suggested by the parents' ability to transfer the embryos.

In Davis $v$ Davis, ${ }^{59}$ a divorcing couple were unable to agree on the disposition of seven frozen embryos. Initially, the wife wished to have them implanted in her womb. The husband objected, as he wished the embryos to be retained in a frozen state, until he decided whether he wanted to be responsible for a child born after the divorce. The trial court held that the embryos were "human beings" from the moment of fertilisation and awarded custody to the wife. The Court of Appeal rejected the notion that the embryos were persons and held that the husband and wife shared an interest in the embryos, and so both had joint control and an equal input into their disposition.

The Supreme Court held that the couple did not have property rights in the embryos, but they had an interest in the nature of ownership, to the extent that they had decision-making authority regarding their disposition. The embryos were not persons or property, but were "an interim category that entitles them to special respect because of their potential for human life." 60 If the parties had agreed about the disposition of the embryos that agreement would have been implemented, but as there

\footnotetext{
${ }^{55}$ Howard W Jones and Lucinda Veeck “What is an Embryo?”(2002) 77 Fertility and Sterility 658659: The egg, when fertilised, spends the first four days making cells. It starts as two and multiplies during this time. During the next 10 days the placenta, amnion, umbilical cord and the other membranes that will be the support system of the embryo are formed. Next comes the clustering of cells together to form the primitive streak, which will develop into the spinal column and central nervous system of the embryo. In the first 14 days, there is no differentiation of cells; any of which might form part of the placenta or the embryo itself. Consequently, 14 days has been considered the limit for research on embryos. By eight weeks after fertilisation, the placenta and all the protective membranes have separated from the embryo and all the main organs of the body and the limbs have formed. Thereafter, the organism is generally referred to as a foetus.

${ }^{56}$ Re an Unborn Child, above.

${ }^{57}$ Note that there has been much discussion as to whether an embryo is a person from the point of fertilisation, in the context of human embryonic stem cell research and abortion. Consensus is unlikely and the arguments often relate to cultural or spiritual values. This issue will not be explored in this thesis.

${ }^{58}$ Human Assisted Reproductive Technology Act 2004, s 10, embryos must not be stored beyond ten years.

${ }^{59}$ Davis v Davis (1992) 842 SW 2d 588 (Tenn Sup Ct).

${ }^{60}$ Davis v Davis, above, 596.
} 
was no agreement, the Court had to weigh the relative interests of the couple. The wife had remarried and now wished to donate the embryos to another couple. The husband's wish to avoid procreation overrode the wife's wish to donate, so the fertility clinic was free to dispose of the embryos.

Subsequent United States cases have emphasised that people have a right not to become parents against their will. ${ }^{61}$ There has been a secondary emphasis on the parties' agreements. ${ }^{62}$ This suggests a “quasi-property” approach towards the embryo, not extending to ownership.

In the United Kingdom, two claimants had each undergone IVF treatment with a partner from whom she subsequently separated, leaving stored frozen embryos. Each woman wished to have the embryos implanted, with a view to becoming pregnant. Both men had withdrawn their consent to the continued storage of the embryos, and wanted the embryos to perish. Wall $\mathrm{J}$ held that there is no property in an embryo, but both gamete donors have an interest in, and rights over, the embryos they have created. ${ }^{63}$ Additionally, embryos cannot be considered to be persons, or to have a “qualified” right to life.

Ms Evans lodged an application with the European Court of Human Rights, asking the Court to consider whether destruction of her stored embryos would be a breach of her human rights. It ruled unanimously that there had been no violation of Article 2- the right to life, or Article 14- the prohibition of discrimination. ${ }^{64} \mathrm{~A}$ majority of five votes to two decided that there had been no violation of Article 8- the right to respect for private and family life. Thus, an embryo did not have independent rights or interests and could not claim, or have claimed on its behalf, a right to life. The dissenting judges took the approach of balancing the private interests of the parties and concluded that the wishes of the party withdrawing consent should not prevail if the other party could not otherwise have a genetically related child, had no children and did not intend to use a surrogate. ${ }^{65}$

In Dickson $v$ United Kingdom, ${ }^{66}$ a case about whether a prisoner could conceive a child through artificial insemination, the Court applied Article 8 of the European Convention of Human Rights, which protects a person's right to respect for private and family life. This is qualified by Article 8(2), which permits interference where it is necessary in a democratic society for reasons such as the protection of the rights and freedoms of others. The issue was whether the interference with the applicants' rights under Article 8 could be justified under Article 8(2). The majority held that the policy served a legitimate public interest, such as preserving confidence in the penal system; so the interference with the applicants' rights was lawful. Bonello $\mathrm{J}$ stated that "permitting offspring to be born to the applicants would not be fostering the best interests of the desired child," ${ }^{67}$ so the refusal was justifiable under Article

\footnotetext{
${ }^{61}$ AZ v BZ (2000) 431 Mass 150 (Mass Probate Ct).

${ }^{62}$ Kass v Kass (1998) 91 NY 2d 554 (NY Ct App).

${ }^{63}$ Evans v Amicus Healthcare Ltd [2003] EWHC 2161 (Fam) Wall J.

${ }^{64}$ Case of Evans v United Kingdom European Court of Human Rights, Application 6339/05.

${ }^{65}$ Case of Evans $v$ United Kingdom, above, 30.

${ }^{66}$ Case of Dickson v United Kingdom European Court of Human Rights, Application no 44362/04, 18 April 2006.

${ }^{67}$ Case of Dickson v United Kingdom, above, Concurring Opinion of Bonello J para 5.
} 
8(2). He treated a child who has not yet been conceived as a person who has rights which are protected by the Convention, a view that could have the consequence, for example, that lawful abortion was incompatible with the right to life under Article 2.

The status of gametes and embryos illustrates the conceptually unsatisfactory state of the law regarding body parts. The rights approach requires a method to balance conflicting rights. The determination of the point at which consent may no longer be withdrawn is based on public policy, rather than rights. If the contract of the parties is determinative, this suggests some form of property interest must exist. Evans $^{68}$ is unsatisfactory, because the woman had to make a rapid decision during a medical crisis and she accepted the assurances of her partner that she did not need to make provision for the possible termination of the relationship. ${ }^{69}$ If the embryos are destroyed, she will have lost her only opportunity to parent a genetically related child. The couple had an agreement, which she relied upon and doing so, acted to her detriment. It seems inequitable for the man to then resile from the agreement.

Public policy suggests that a man should not become a father against his will, although that is not an uncommon occurrence with natural conception. If each party had a property interest in their gametes, then they would have a joint (or common) interest in the resultant embryos. If they were unable to agree about disposition, the embryos would be divided between the parties. However, arguably, abandonment of the embryos by one party should result in the full interest passing to the other, rather than destruction.

\section{Research Using Embryos}

Research use of human embryos has become a matter of great scientific interest, particularly the creation of embryonic stem cell lines. If it is believed that embryos are "persons", such research would amount to killing one person to benefit another.

Stem cells are a potential source of new cells, for example blood stem cells will replenish and enrich blood cells. Embryonic stem cells are still in a pluripotent state and have the potential to develop into any of the human cell types. They have the ability to renew themselves, by undergoing an unlimited number of divisions, for an indefinite amount of time. Human stem cell research could be of use in formulating new therapies, by assisting with the development and testing of new drugs. Additionally, differentiated derivatives of human embryo stem cells could be applied to transplantation therapies and may enable the treatment of diseases resulting from abnormal cell division and specialisation.

The most efficient method of obtaining stem cells is to extract them from early human embryos, which results in the destruction of the embryo. Although many countries have regulated research that uses human reproductive material, the United Kingdom is presently the only country in Europe that allows the creation of human embryos specifically for research purposes, including the use of cloning techniques. ${ }^{70}$

\footnotetext{
${ }^{68}$ Evans v Amicus Healthcare Ltd, above.

${ }^{69}$ For example, by fertilising some of her eggs with donor semen.

70 The United States Code and Federal Register contain legislation that defines the degree of protection that must be given to the material in the course of experimentation.46 CFR @ 26.208 (a)(2) (1996); 42
} 
A House of Lords Select Committee reviewed the science and ethics of stem cell research and the resultant regulatory issues. ${ }^{71}$ Its view was that that the embryo should be respected without requiring total protection, so research on early human embryos should not be prohibited. ${ }^{72}$ Respect for persons necessitates research to save lives so, unless early embryos have an unconditional claim to protection, it is wrong to rule out research, involving them. It recommended that 14 days should remain the limit for research on early embryos ${ }^{73}$ and that embryos should only be created specifically for research purposes if there is a demonstrable and exceptional need that cannot be met by the use of surplus embryos. ${ }^{74}$

In New Zealand, an advisory committee (ACART) will develop advice to the Minister and guidelines on assisted human reproductive procedures and research, within which the ethics committee (ECART) is required to operate. ${ }^{75}$ ACART must produce advice for the Minister in 2007 and opinions are no doubt as divided as in other countries where the issue has been debated. ${ }^{76}$

If embryos are people, such research attempts to prolong the lives of some people by destroying younger persons. "Those opposed to research on embryos are concerned that we are on a slippery slope, facing a creeping moral degradation fostered by unbridled technology."77 Slippery slope arguments are speculative and must be weighed against the potential benefits from research.

If embryos are the property of the gamete providers they could transfer them to other couples or to researchers. However, most jurisdictions require controls in addition to the consent of the providers. This does not mean the property construct is inapplicable to embryos, as in many other areas there are legislative controls over the uses of property, if public policy has determined that private interests should be constrained.

\section{DEATH}

U.S.C.S. @289 (g). In the United Kingdom, the Human Fertilisation and Embryology Act 1990 controls research that utilises human embryos. In Australia, the Victorian Infertility Treatment Act (1995) and the South Australian Reproductive Technology Act (1988) provide controls over the use of embryos for research. To date, only two European states have adopted regulations expressly authorising such research, whilst the majority have either no legislation, or have introduced restrictive legislation prohibiting embryo research. The Swedish Research Council has issued guidelines endorsing the use of Cell Nuclear Replacement (December 2001) and the Netherlands has adopted legislation allowing CNR after a moratorium of five years (October 2001). In both cases research is only permitted on surplus embryos. L Matthiessen (ed) Survey on Opinions from National Ethics Committees or Similar Bodies, Public Debate and National Legislation in Relation to Human Embryonic Stem Cell Research and Use (European Commission, Geneva, 2001).

${ }^{71}$ Stem Cell Research HL Paper 83(i) (Report) and 83(ii) (Evidence) (HMSO, London, 2002).

${ }^{72}$ Stem Cell Research, above, 4.21.

${ }^{73}$ Stem Cell Research, above, 4.22.

${ }^{74}$ Stem Cell Research, above, 4.28.

${ }^{75}$ The merits of ethics committees are considered further in chapter 8. ACART is working with the Bioethics Council to inform and engage with the public to encourage public involvement in ACART's processes.

${ }^{76}$ TNS Human Embryo Research Qualitative Research Report (TNS, Wellington, 2006)

$<$ www.bioethics.org.nz> (last accessed 8 November 2006).

${ }^{77}$ Gerald D Fishbach and Ruth L Fishbach “Stem cells: science, policy and ethics” (2004) 114 J Clinic investig 1364, 1369. 
This thesis argues that the property interest in cadavers passes to the representative of the deceased at death; consequently it is vital to know the point at which death occurs. Previously, there was little dispute about the appropriate criteria for diagnosing death. However, new technologies have rendered redundant the previously accepted view that clinical death always involves the virtually simultaneous loss of cardiopulmonary and neurological function. Circulation and respiration can now be artificially maintained, despite apparent cessation of the neurological function. The development of organ transplantation and the need for organ donation from "beating heart donors", together with the increasingly diverse use of body materials, required a redefinition of death.

The "dead donor rule" necessitates that donors of vital organs be declared dead before harvest, to avoid charges of unlawfully killing the source. Organ harvest appeared to involve a form of murder, but the redefinition of death as "brain death" allowed organ transplantation to continue. Commentators have argued the concepts that underlie brain death are not biologically plausible and may be unacceptable to the community at large. This may, in part, explain the low organ donation rate in New Zealand and Australia. Singer argues that brain death is a "convenient fiction" to facilitate organ transplantation. ${ }^{78}$

In 1988, the Danish Council of Ethics focussed on the perceived difference between scientific and ordinary views of death. ${ }^{79}$ It stated that the concept of death must relate to everyday experience, in which the identity of the person relates to the body and the mind. It recommended that the standard of death should be the cessation of respiration and cardiac activity.

\section{A Development of the Concept of Brain Death}

In 1968, the Ad Hoc Committee of the Harvard Medical School to Examine the Definition of Brain Death issued a report containing a new brain-based set of criteria for determining death. If physicians had established "permanent loss of brain functions, from consciousness to primitive brain stem reflexes" a patient could be diagnosed as "dead". ${ }^{80}$ It was assumed that society would accept the authority of medical science and make the necessary changes to ideas of death and personhood, so transplantation could proceed. ${ }^{81}$ The Report justified the new criterion, by citing the need for standards by which to determine when resuscitative and support care should

\footnotetext{
${ }^{78}$ Peter Singer Rethinking Life and Death (Oxford University Press, Oxford, 1994) 35.

${ }^{79}$ Danish Council of Ethics Report The Criteria of Death (Danish Council of Ethics, Copenhagen, 1988).

${ }^{80}$ M Pernick "Brain Death in a Cultural Context: The Reconstruction of Death, 1967-1981” in S Youngner, R Arnold and R Shapiro (eds) The Definition of Death: Contemporary Controversies (The Johns Hopkins Press, Baltimore, 1999) 3.

${ }^{81}$ Russell Scott The Body as Property (Viking Press, New York, 1981).
} 
be terminated. However, there is little doubt that the priority of harvesting organs for transplantation was an equally important motivating factor. ${ }^{82}$ In 1981, the President's Commission for the Study of Ethical Problems in Medicine and Biomedical and Behavioral Research recommended that the permanent loss of all brain functions be adopted as a criterion for diagnosing death, in addition to conventional cardiopulmonary criteria. ${ }^{83}$

The "higher" brain definition of brain death includes patients who have permanently lost consciousness, but are able to breathe unaided. Consciousness-based criterions have not been introduced into public policy or law, because:

- $\quad$ Spontaneously breathing patients are not apparently dead;

- $\quad$ The clinical tests to determine irreversible loss of consciousness are not as definitive as those for brain death;

- $\quad$ Consciousness is supported by anatomical regions in both the brain stem and the cerebral hemispheres, and

- $\quad$ Even among higher brain advocates there is disagreement about whether the critical factor is the loss of personhood, rather than consciousness. ${ }^{84}$

"Higher" brain death proponents would assert that Bland was already dead and thus his organs could be taken while his heart was still beating. It is unlikely that the public would accept this notion. Thus, irreversible cardiopulmonary cessation remains as the proper criterion for the determination that the brain death standard has been satisfied.

Organ Donation New Zealand is considering whether to use "non-heartbeating donors" to improve low donor rates. Unlike brain-dead patients, whose organs are retrieved while the heart is still beating, non-heart-beating donors are first allowed to die before their organs are removed. ${ }^{85}$ Australia and Britain have been using this category of donors for some time. The main disadvantage is that the organs could be of lower quality, reducing survival and function rates.

Brain death is not the death of the entire organ, but rather the loss of all functions of the brain. Pallis identified the capacity for consciousness and spontaneous respiration as the critical functions, because loss of brain stem function

\footnotetext{
${ }^{82}$ David Rothman Strangers at the Bedside: A History of How Law and Bioethics Transformed Medical Decision Making (Basic Books, New York, 1991).

${ }^{83}$ President's Commission for the Study of Ethical Problems in Medicine and Biomedical and Behavioral Research Defining Death: Medical Legal and Ethical Issues in the Determination of Death (Government Printing Office, Washington DC, 1981) 119.

${ }^{84}$ E T Bartlett and S T Youngner "Human Death and the Destruction of the Neocortex" in R M Zaner (ed) Death: Beyond the Whole-Brain Criteria (Kluwer Academic Publishers, Dordrecht, 1988) 199, 215.

${ }^{85}$ Once the decision to withdraw treatment is reached, medications such as blood thinners and blood vessel dilators are often started to preserve the organs. When the ventilator is removed, doctors wait for the patient's heart and breathing to stop, declare cardiac death either immediately or after a waiting period of two to five minutes and then take the organs. The legal standard of irreversible cardiac death is considered met because the decision has already been made not to restart the heart by cardiopulmonary resuscitation and the heart is not expected to resume beating on its own. John T Potts and Roger Herdman Non-Heart-Beating Organ Transplantation: Medical and Ethical Issues in Procurement (National Academy Press, Washington DC, 1997).
} 
effectively eliminates both. ${ }^{86}$ Subsequently, clinicians have accepted that the essential physiological component of brain death is the death of the brain stem, and the diagnosis of brain death is made by examining the functioning of nerves that originate there. Although the "whole brain" criterion of death has been widely accepted since 1981, some societies, such as Denmark, Poland and Japan, were slow to accept it. Others, such as China, Iran, Israel and Korea, still either wholly or partially reject it. ${ }^{87}$ According to Truog: ${ }^{88}$

\begin{abstract}
At a practical level, [the concept of brain death] has been successful in delineating widely accepted ethical and legal boundaries for the procurement of vital organs for transplantation. Despite this success, however, there have been persistent concerns over whether the concept is theoretically coherent and internally consistent. Indeed, some have concluded that the concept is fundamentally flawed and that it represents only a "superficial and fragile consensus".
\end{abstract}

In New Zealand there is no relevant legislation, other than the Human Tissue Act 1964, which requires a registered medical practitioner to be satisfied, by personal examination, that "life is extinct". ${ }^{89}$ The Human Tissue Bill retains this provision and is silent with regard to the definition of death. In the United Kingdom, the Code of Practice 1998 states that "brain stem death equates with the death of the individual." 90

In Auckland Area Health Board v Attorney-General, ${ }^{91}$ Thomas J stated: ${ }^{92}$

With the advances in technology and medical skills which have occurred, the medical profession has rejected the notion that death is to be equated with the cessation of a person's heartbeat. In open-heart surgery, for example, the patient's heart is temporarily stopped, but it is not thought that he or she has died. Instead the medical community has preferred the concept of what is called "brain death".

Thomas $\mathrm{J}$ added that, although brain death has not been formally adopted in New Zealand law, it is widely accepted by the medical profession.

\title{
B Concerns about Brain Death
}

Although the Harvard Committee may have been certain that social consensus would rapidly follow their proposal, the public response in the United States was not positive. Rothman documents negative reaction, demonstrated by numerous popular press articles, following publication of the committee's report. ${ }^{93}$ The redefinition of death based on brain activity remains the subject of significant cultural ambivalence

\footnotetext{
${ }^{86}$ C Pallis and D H Harley ABC of Brainstem Death (BMJ Publishing Group, London, 1996).

${ }^{87}$ David Price Legal and Ethical Aspects of Organ Transplantation (Cambridge University Press, Cambridge, 2000) 41.

${ }^{88}$ R D Truog “Is it Time to Abandon Brain Death?” (1997) 27 Hastings Cent rep 29, 37.

${ }^{89}$ Human Tissue Act 1964, s 3(4) "No such removal shall be affected except by a medical practitioner, who must have satisfied himself by personal examination of the body that life is extinct.” The Human Tissue Bill, clause 50 contains a similar provision.

${ }^{90}$ Department of Health A Code of Practice for the Diagnosis of Brain Stem Death: Including Guidelines for the Identification and Management of Potential Organ and Tissue Donors (Department of Health, London, 1988) 4.

${ }^{91}$ Auckland Area Health Board v Attorney-General [1993] 1 NZLR 235 (HC) Thomas J.

${ }^{92}$ Auckland Area Health Board v Attorney-General, above, 246.

${ }^{93}$ David Rothman Strangers at the Bedside: A History of How Law and Bioethics Transformed Medical Decision Making (Basic Books, New York, 1991)163-164.
} 
and intensive care nurses state that it is difficult to explain to relatives that the heartbeating, apparently alive, patient is actually dead. ${ }^{94}$ Research in minority communities on attitudes towards organ donation indicates wide spread suspicion that brain death might be declared prematurely, in order to provide organs for transplantation. ${ }^{95}$

A 1995 study showed that about 20 per cent of families of brain-dead patients continued to have doubts about whether their relative was actually dead, even after brain death was explained to them, while a further 66 per cent accepted that the patient was dead, but felt emotionally that they were still alive. This experience did not appear to be related to whether the families agreed or disagreed with organ donation. ${ }^{96}$ Physicians and nurses also indicate considerable philosophical confusion about the concept of brain death and a wide range of personal views about when life ends. ${ }^{97}$

When the concept of brain death was first introduced, it was argued that death of the brain stem inevitably implied the imminent death of the whole body. Even with ventilation and intensive care, such persons inevitably had a cardiac arrest within weeks. $^{98}$ This is no longer the case, as medical therapy and intensive care have become increasingly sophisticated at replacing brain stem function, so brain dead patients can be kept alive for extended periods. ${ }^{99}$ Brain dead pregnant women have been maintained for months and given birth to healthy infants, and brain dead children have been reported to survive for up to 14 years with ventilatory and nutritional support. ${ }^{100}$ Some show evidence of environmental responsiveness, such as a hemodynamic response to surgical incision. ${ }^{101}$ It has been reported that 10 out of 10 organ donors in one study showed a dramatic rise in blood pressure and heart rate as soon as the scalpel was applied during organ removal, and that such an occurrence appears to be common during organ harvesting. ${ }^{102}$

It has been argued that it is biologically and philosophically simplistic to suggest that the brain stem is the supreme regulator of the body. ${ }^{103}$ It is true that, unlike the heart lungs or kidneys, the brain stem cannot be replaced by technological

\footnotetext{
${ }^{94}$ Pat S Helmberger Transplants: Unwrapping the Second Gift of Life (Chronimed Publishing, Minneapolis, 1992).

${ }^{95}$ Clive O Callender “Organ Donation in Blacks: A Community Approach” (1987) 19 Transplantation Proceedings 1551.

${ }^{96}$ I Y Pearson, P Bazely, T Spencer-Lane and others "A Survey of Families of Brain Dead Patients: Their Experiences, Attitudes to Organ Donation and Transplantation.” (1995) 23 Anaesthesia and Intensive Care 88.

${ }^{97}$ Stuart C Youngner, C S Landefeld, CJ Coulton and others ““'Brain death’ and Organ Retrieval: A Cross-sectional Survey of Knowledge and Concepts Among Health Professionals.” (1989) 261 JAMA 2205.

${ }^{98}$ C Pallis “ABC of Brain Stem Death” (1983) BMJ 123-4; B Jennet and C Hessett “Brain Death in Britain as Reflected in Renal Donors” (1981) BMJ 359.

${ }^{99}$ F Shann “A Personal Comment: Whole Brain Death Versus Cortical Death” (1995) 23 Anaesthesia and Intensive Care 14.

${ }^{100}$ D Alan Shewmon "The Brain and Somatic Integration: Insights Into the Standard Biological Rationale for Equating ‘Brain Death’ with Death” (2001) 26 J Med \& Phil 457—478.

${ }^{101}$ K G Karakatsanis and J N Tsanakas “A Critique on the Concept of 'Brain Death'” (2002) 18 Issues in Law and Medicine 127.

${ }^{102}$ Randall C Wetzel and others “Hemodynamic Responses in Brain Dead Organ Patients” (1985) 64 Anaesthesia \& Analgesia 125, 126-127.

${ }^{103}$ I H Kerridge, P Saul, M Lowe and others "Death, Dying and Donation: Organ Transplantation and the Diagnosis of Death” (2002) 28 J med ethics 89, 97.
} 
means, but neural tissue repair may be possible through future developments in human embryonic stem cell research. ${ }^{104}$ stated: ${ }^{105}$

Thomas $\mathrm{J}$ recognised the inexactitude of the definitions of death when he

\begin{abstract}
Whether or not ever-advancing technology and the maturity of thought which be no more than the product of the passage of time will lead to a further revision of the moment when a person can be accounted dead is an open issue. That is as it should be. It will ultimately be for the medical profession, sensitive to the values of the community and alert to the requirements of the law, to decide whether the irrevocable destruction of nerve tissues which are imperative to breathing and heartbeat as are the "tissues" which constitute the brain stem, require the definition of death to be revised.
\end{abstract}

Kerridge and others argue for the abandonment of the "dead donor rule" and support organ harvest from patients without defining them as dead. The identification of brain stem death would be for its prognostic value only. There would be no change in eligibility for organ donation, but it would place much greater emphasis on consent and make the decision to donate more complex for families. They argue: ${ }^{106}$

\begin{abstract}
If families are told that brain stem criteria define the point where consciousness is not recoverable and where physical recovery is impossible, but where organ donation is an option, although the patient is not yet dead, this may be more commensurable with common morality and may more honestly acknowledge the layers of moral difficulty in the present situation. Rather than defining those who are "brain dead" as "dead" it may be more honest to acknowledge that such individuals are not dead and that removing their organs is in fact killing them. Such an action is undeniably morally troubling; it may, however, be morally justifiable in precisely defined circumstances such as where recovery is impossible and personal identity is lost. It may also be less morally objectionable than the creation of a fiction (the redefinition of death) which is the only alternative. The long term viability of transplantation programmes is likely to be better served by telling the truth than trading in fictions.
\end{abstract}

Kappelman states that the dead donor rule is misguided and that the focus should be on the particular patient's history, as, if the person has indicated by way of advance directive a wish to allow the body to be used for transplantation or experimentation, this should be honoured, even if it involves the removal of organs from a person who is in a PVS. She does not recommend such an action if the person has not made an advance directive, as relying on familial perceptions of the person's probable views is subject to error. Such an approach would require legislative change to provide for the removal of organs from a person whose death is imminent, with careful definition of imminent. It seems unlikely that such a move would be politically or socially attractive, even if the aim was to increase the availability of organs for transplantation.

This thesis suggests that Price is correct when he suggests that it is preferable to have a statutory definition of death with a unitary definition, rather than a binary

\footnotetext{
${ }^{104}$ Kerridge and others, above, 97.

${ }^{105}$ Auckland Area Health Board v Attorney-General [1993] 1 NZLR 235, 246 (HC) Thomas J.

${ }^{106}$ Kerridge and others, above, 97.
} 
system by which death is either brain death or cardiopulmonary cessation. ${ }^{107}$ This is to avoid the possibility that a person might be dead by one set of criteria and not dead by another. He supports the approach of the Canadian Law Reform Commission, which provides:

- A person is dead when an irreversible cessation of all that person's brain functions has occurred;

- The irreversible cessation of brain functions can be determined by the prolonged absence of spontaneous circulatory and respiratory functions;

- When the determination of the prolonged absence of spontaneous circulatory and respiratory functions is made impossible by the use of artificial means of support, the irreversible cessation of brain functions can be determined by any means recognised by ordinary standards of current medical practice. ${ }^{108}$

\section{CONCLUSIONS}

At present, there are few legal principles that directly determine personhood. This thesis argues for a framework incorporating property interests in biological materials, so, it is necessary to determine when the interest arises and when it passes to the representative of the deceased.

This involves considerations of personhood at the beginning and end of life and with respect to permanently insentient persons. Commentators have argued that individuals who are permanently insentient have no interests and therefore cannot be harmed, so there is no need to find a justification for organ retrieval or research involving them. The perceptions of "interest-less", but living, beings are based on a mind/body dualism, which is not generally supported by mainstream religious, secular or legal thought. Keown stated: ${ }^{109}$

\footnotetext{
The law has hitherto rejected the notion of "biological units" which are "inhabited" by a non bodily person and has, on the contrary, taken the traditional, commonsense view that human life is personal life, that living human beings are persons and that persons are, applying standard biological criteria, either alive or dead.
}

As is shown in this chapter, this view reflects judicial perceptions, and arguably, also reflects the instinctive views of a substantial proportion of the community. Thus personhood, and consequently, the property interest in excised body parts, should remain with the person until death, but people should be able to specify, by way of advance directive, the manner in which treatment is to be withdrawn, should they wish to ensure their organs are able to be used.

There is a tension in many transplant protocols between the human source's rights to autonomy and dignity, and the interests of transplantation and research. The conceptual difficulties suggest that the point at which organs might validly be retrieved should be dealt with by legislation. This thesis argues that death should be

\footnotetext{
${ }^{107}$ David Price Legal and Ethical Aspects of Organ Transplantation (Cambridge University Press, Cambridge, 2000) 78.

108 Price, above, 79.

109 J Keown "Restoring Moral and Intellectual Shape to the Law after Bland” (1997) 113 LLQR 481, 493 (emphasis in the original).
} 
legislatively defined and suggests it is an irreversible cessation of all of a person's brain functions, assessed by ordinary standards of current medical practice.

If organ donation and research using human body materials are seen as social goods, then it is essential that the public support such endeavours. The use of the human body and its parts is a highly sensitive area, in light of cultural and religious perception of the body and support is best achieved through open debate of the issues, rather than relying on comfortable fictions, such as asserting that a brain dead person on life support is dead.

The cases considered generally conclude that gametes and embryos must be dealt with in accord with the sources' agreements with the clinics storing them. This thesis suggests that frozen embryos are the common property of the "parents". As such, they should be divided between them in the event of a dispute, rather than being destroyed unless both parents agree to their use. This may result in some men becoming fathers against their will, but men are not uncommonly unwitting sperm donors by natural means. ${ }^{110}$ It is argued that embryos are not persons and that personhood, and thus potential property interests, only arise when a child is born alive although the law may, as a matter of public policy, regulate the uses and treatment of embryos and foetuses.

\footnotetext{
${ }^{110}$ It would be reasonable to accept that a man in such a situation has no obligation to maintain the resultant child.
} 


\title{
Chapter 5
}

\section{THE MĀORI PERSPECTIVE}

\section{INTRODUCTION}

In previous chapters it was argued that the autonomy interests of sources in their excised body parts and their concern to control the use of their bodies following death are best promoted by recognising property interests in excised parts and dead bodies. However, cultural imperatives may impair the ability to make autonomous choices. In this chapter, Māori perspectives on the retention and use of human body parts will be considered. ${ }^{1}$ It will be argued that a framework proposed for New Zealand must encompass the Māori world-view, particularly in light of the provisions of the Treaty of Waitangi ${ }^{2}$ relating to taonga.

Flexibility and adaptability to changing circumstances have enabled the survival of many Māori customs and cultural values and there are likely to be significant benefits from maintaining and encouraging the healing, dying, death and grieving processes that are central to Māori culture. The number of people who are descended from Māori and, of those, the number who identify themselves as Māori, can be determined from the New Zealand census. ${ }^{4}$ In 1996, almost half of all Māori identified with at least one other ethnic group. Consequently, the framework would allow individual sources to choose whether or not to act in accord with tikanga Māori, ${ }^{5}$ to avoid assumptions about their values.

Although Māori usually appear to be westernised, Māori cultural heritage influences ideas, attitudes and reactions, especially with respect to illness. Māori believe that each person is an event within the ongoing procession of nature. ${ }^{6}$ Shortland, writing in 1856, observed that Māori imagined sickness originated from the entrance of spirits into the body of the sufferer. ${ }^{7}$

The Law Commission stated: ${ }^{8}$

\begin{abstract}
Māori law does not tolerate the removal or retention of body parts. Māori consider that all parts of the body are imbued with a life spirit handed down from the ancestors, contributed to by each successive generation, and passed on to future generations. Since Māori view their most sacred role as being the preservation of the dignity of their ancestors, the removal or retention of body parts is sacrilegious to them. It undermines their cultural values and prevents them from carrying out their responsibilities in relation to the deceased.
\end{abstract}

\footnotetext{
${ }^{1}$ Note that many of the Māori concepts discussed herein do not directly translate into English.

Consequently, the translations given are only approximations of meanings.

${ }^{2}$ See discussion of the Treaty of Waitangi below.

3 Treasures.

${ }^{4}$ In the 1996 census, a total of 579,714 people indicated they were descended from a Māori, while only 85 per cent of these, 523,374, actually identified as Māori. Statistics New Zealand New Zealand Now: Māori (Department of Statistics, Wellington, 1998) 13.

${ }^{5}$ Māori custom.

${ }^{6}$ Maori Marsden "God, Man and Universe: A Maori View" in Michael King (ed) Te Ao Hurihuri: The World Moves On (Hicks Smith \& Sons/Methuen NZ Ltd, Auckland, 1977) 162.

${ }^{7}$ Edward Shortland Traditions and Superstitions of the New Zealanders (Longman Brown Green, Longmans \& Roberts, Paternoster Row, 1856) 114.

${ }^{8}$ Law Commission Coroners: A Review (Preliminary Paper 36, Law Commission, Wellington, 1999) 9.
} 
Although Māori removed body parts from conquered enemies in times of war, this was consistent with cultural beliefs of mana ${ }^{9}, \operatorname{tapu}^{10}$ and mauri ${ }^{11}$.

There are inherent difficulties in attempting to describe the concepts and values of one culture using the language of another. However, the most basic contrast between Māori and European world views is that Māori culture puts spiritual and communal matters ahead of material and individual needs. It emphasises the primacy of nature and the need for man to tread carefully when interfering with natural laws and processes.

The consideration of Māori views in this chapter will be confined to consideration of the removal and use of body parts in contemporary times, in the context of organ donation and research. In light of the low rate of Māori organ donation, attitudes to sickness and death and strategies to increase the donation rate will be considered. It is argued that conscription and presumed consent are inappropriate in New Zealand, because of the potential for cultural offence and loss of trust in the medical profession. The proposed property interest, which would pass to a representative at death, would allow Māori to choose whether to make decisions individualistically or collectively by appointing as representative a person with mana $^{12}$, such as a kaumatua ${ }^{13}$, to exercise the decision-making function.

Research holds promise for treatment of conditions affecting Māori, but there is disquiet about genetic modification and the exploitation of indigenous resources. It is suggested that consultation and collective decision-making about research projects should take place at the point of ethics committee approval, rather than when tissue is collected. There is a danger that consultation with Māori will be limited to mere acknowledgement of their world-view, as the potential benefits of medical research are more easily quantified than are the risks from cultural offence. This is demonstrated in this chapter by the section on transgenic animals.

\section{BASIS OF THE MĀORI WORLD VIEW $W^{14}$}

\section{A Contemporary Health Model}

A view of health that accords with contemporary Māori thinking is the whare tapu wha ${ }^{15}$ model. ${ }^{16}$ The model compares health to the four walls of a house, all four being necessary to ensure strength and symmetry. The four sides are tahu wairua (the spiritual side), tahu hinengaro (thoughts and feelings side), taha tinana (the physical side) and taha whānau (family side). As stated by Durie: ${ }^{17}$

\footnotetext{
${ }^{9}$ Authority, status.

${ }^{10}$ Divine.

${ }^{11}$ Life principle.

${ }^{12}$ Status.

${ }^{13}$ Elder.

${ }^{14}$ This thesis does not suggest there is a single Māori world view, but attempts to demonstrate some fundamental principles.

${ }^{15}$ Whare $=$ house, tapu $=$ sacred wha $=$ four.

${ }^{16}$ Mason Durie Whaiora: Māori Health Development (Oxford University Press, Auckland, 1994) 70.

${ }^{17}$ Durie, above, 71.
} 
The four dimensions of health were originally portrayed as a set of interacting variables, not dissimilar from a holistic view, nor for that matter from the World Health Organisation 1947 definition but, unlike them, firmly anchored on a spiritual rather than a somatic base.

Taha wairua ${ }^{18}$ is the most essential requirement for health. It involves the spiritual components of faith and the links between the human situation and the environment. This spiritual aspect includes, but does not require, a religious belief. The relationship with the environment is integral to identity and a strong sense of well-being. Durie states: ${ }^{19}$

\begin{abstract}
Spiritually, the hours immediately following death are particularly significant. As the deceased person's spirit hovers tentatively between the visible world and the world of spirits, mourners themselves are able to feel a spiritual presence and to experience a renewed sense of continuity with their own ancestors, their history, and their future. For that reason a rapid retrieval of a deceased relative from hospital becomes a matter of urgency.
\end{abstract}

Early retrieval of a relative's body is critical to upholding the mana of the family and the individual, thus, bereaved Māori families are often offended if the body is not released within 24 hours after death. ${ }^{20}$

Taha hinengaro concerns the expression of thoughts and feelings. Understanding occurs by synthesis into wider contextual systems, so that any recognition of similarities is based on comparisons at a higher level of organisation. Health is viewed as an interrelated phenomenon, rather than an inter-personal one. Poor health is regarded as a breakdown in harmony between the individual and the wider environment. Te taha hinengaro must be considered alongside physical wellbeing in events such as the removal, retention, or return of body parts, organ donation and post-mortem procedures. The whānau ${ }^{21}$ needs to be able to grieve together, to have time to provide support and the opportunity to discuss different aspects of the process, so that all can achieve te taha hinengaro.

Taha tinana involves a belief that certain parts of the body, and particularly the head, are special (tapu) and bodily functions such as sleeping, eating, drinking and defecating have special significance and rituals. Tapu and noa are vital concepts to Māori cultural views. Tapu accords respect and mana to certain people, objects, events, places and parts of the body. In particular, tapu status has traditionally been accorded to human hair, blood and mucus, which are the main sources used by researchers to access DNA. Noa is the concept that ensures that tapu people can be approached, or that tapu objects are able to be used. Whakanoa, the practice of removing or weakening the tapu, allows such objects to be used without any resultant harm to the user. For many Māori, tapu and noa are fundamental to the tikanga ${ }^{22}$ that Māori carry out in a wide range of activities, including births, deaths and marriages. Traditionally, tapu and noa were used as interventions for the protection and promotion of health. ${ }^{23}$

\footnotetext{
${ }^{18}$ Spiritualism.

${ }^{19}$ Durie, above, 71.

${ }^{20}$ Durie, above, 71.

${ }^{21}$ Family.

${ }^{22}$ Custom.

${ }^{23}$ Durie, above, 70-74.
} 
The fourth dimension of health, taha whānau, relates to the importance of the extended family to health. The family is the prime support system, providing physical, cultural and emotional care. Interdependence, rather than independence, is valued. Individual health is integrated into a wider system, with the boundary between personal and family identity unclear.

The events surrounding times of serious illness, dying, death and grieving are among the most sacred and important in Māori life. Once the tangata mauiui ${ }^{24}$ and their whānau are involved with a healthcare service, they are deemed to be in a state of noa (being beyond one's own physical and/or spiritual power). They become disempowered. Acknowledging their rites and respecting their beliefs restores the tapu (well-being) of tangata mauiui and their whānau. Following removal, human tissue and substances are tapu and must be handled with respect and treated with dignity.

When a person dies, they enter the state of tūpāpaku, in which the person's spirit or soul is separated from the physical body, but remains close by. It is the responsibility of whānau to care for and protect the tūpāpaku and to see that body fluids, tissues and substances are cared for in an appropriate manner. ${ }^{25}$ Spiritually, the hours immediately following death are highly significant. The tangihanga ${ }^{26}$ is a time of great sorrow, but it is also believed that it is appropriate to face the world of the living again, so the immediate whānau, local hap $\bar{u}^{27}$, and manuhiri ${ }^{28}$ stay overnight with the deceased.

Many Māori believe that the healthcare system over-emphasises the physical aspects of health, in its biological constructs and emphasis on cellular phenomena, to the detriment of ecological and caring considerations. As stated by Durie: ${ }^{29}$

\section{While scientific method often dissects the whole into smaller parts in order to find the truth, Māori philosophical methods work in the opposite direction; truth is a function of wider relationships and higher order synergies.}

Other Māori health perspectives have been mooted, but they all attempt to widen the meaning of health to incorporate culturally significant concepts and to balance physical and biological approaches with cultural and sociological views. The relationships that confer coherence within the natural world are the fundamental starting point upon which Māori world-views are built.

\section{B The Relevance of the Treaty of Waitangi}

As long ago as 1837 , there was concern about Māori health, which was one of the motivating factors leading to the Treaty of Waitangi. Busby ${ }^{30}$ was concerned

\footnotetext{
24 The patients.

${ }^{25}$ Auckland District Health Board Body Parts Tissues and Substances Review Panel Report (Auckland District Health Board, Auckland, 2002) 23.

${ }^{26}$ Wake.

${ }^{27}$ Clan.

${ }^{28}$ Guests, visitors.

${ }^{29}$ Mason Durie "Mana Tangata: Culture Custom and Transgenic Research" (Deputy Vice-Chancellor's Lecture, Massey University, Wellington, 5 August 2003) 12.
} 
that Māori might disappear, as a consequence of introduced disease and lifestyle factors. He urged the Colonial office to take action, stating that, without intervention, Māori would be vulnerable to the evils of British settlement. ${ }^{31}$ The Treaty of Waitangi was the proposed solution. The Preamble to the Treaty contained the objectives. Article one provided for a transfer of sovereignty, Article two provided for a continuation of existing property rights and Article three provided for citizenship rights. There were two texts, one in English and one in Māori. The English version is more expansive in Article one and the Māori version broader in its interpretation of Article two. As stated by Mead, Māori found the concept of sharing land and resources acceptable, subject to the existence of a constitutional code to articulate rights and responsibilities, regulate behaviours, and accommodate access rights of settlers, without compromising the guardianship/ownership rights of Māori. ${ }^{32}$

Article two has particular relevance to Māori health. The English version amounted to a confirmation of existing property rights, together with a guarantee that they would not be unjustly alienated, while the Māori version incorporated social and cultural guarantees. As stated by Durie: ${ }^{33}$

\begin{abstract}
By equating "full exclusive and undisturbed possession" with "tino rangatiratanga" the effect was to recognise the authority of chiefs, generally. Moreover the translation of "other properties" (by implication the English version meant physical properties) as "taonga katoa" further extended the meaning to include cultural as well as material properties.
\end{abstract}

Te tino rangitiratanga reflects the status of Māori as tangata whenua ${ }^{34}$ and gives rise to rights of self-determination and tribal self-development. It incorporates the rights and responsibilities to make decisions on the use, control and protection of natural resources, according to Māori cultural values and customary practices. ${ }^{35}$

Taonga resources, in this sense, include significant species and traditional knowledge that might be used to create new life-forms, or to be the subject of a patent. Māori see the issues involved in patents and intellectual property in life-form inventions as a subset of the rights of ownership, ${ }^{36}$ but the patent system does not deal with the fundamental issues of the ownership of the original life-forms from which inventions might be derived. ${ }^{37}$ However, patents do create effective property rights, which Māori assert flow from ownership of the original life-form-the right to use that life-form as a source of biological material for genetic research. Māori argue that the grant of exclusive monopoly rights to life-forms explicitly ignores Māori

\footnotetext{
${ }^{30}$ The British Resident in New Zealand from 1832.

${ }^{31}$ P Adams Fatal Necessity: British Intervention in New Zealand 1830-1847 (Oxford University Press, Auckland, 1977) 88.

${ }^{32}$ Aroha Te Pareake Mead "How are the values of Maori going to be considered and integrated in the use of plant biotechnology in New Zealand?" (Paper presented to the Talking Technologies Conference on Plant Technology, Wellington, 8 May 1999).

${ }^{33}$ Durie, above, 84.

${ }^{34}$ Natives of the land.

${ }^{35}$ Ministry of Commerce Maori and the Patenting of Life Form Inventions. An information paper produced by the Patenting of Life Forms Focus Group (Putahi Associates for the Ministry of Commerce Wellington,1999) <http://www.moc.govt.nz> (last accessed 25 March 2003).

${ }^{36}$ Ministry of Commerce, above, part 1.

${ }^{37}$ See the discussion in chapter 7.
} 
traditions and cultural values and denies input from Māori regarding their ownership, use and control. The current system does not provide Māori with adequate protection for their taonga, because intellectual property laws require individual or joint ownership to be clearly established, before protection can be given. It can be difficult to determine who originally created Māori traditional knowledge and culture, as these have been developed over generations and are collectively owned. Even if knowledge is not shared, the holders of restricted knowledge probably do not have the right to commercialise it for personal gain. Additionally, Māori want enduring protection of their cultural and intellectual property, but the current system only provides for limited periods of protection. ${ }^{38}$

Article three promised "all the rights and privileges of British subjects". This implied not only that there would be citizenship rights, but also equity, an aspect that remains relevant in light of continuing disparities in standards of health between Māori and non-Māori. Although the two versions of the Treaty varied, this variation was, to some extent, addressed by the Treaty of Waitangi Act 1975, which required the newly established Waitangi Tribunal to take into account the principles of the Treaty and gave it statutory authority to decide what those principles were.

Although it has been used to aid the interpretation of the law generally, the Treaty of Waitangi has been enforceable only when it has been incorporated into legislation. Some Acts contain a reference to the principles of the Treaty of Waitangi, ${ }^{39}$ while others refer to Māori interests, but do not go so far as stating that the Crown has an obligation to take into account the principles of the Treaty of Waitangi. However, each Act requires that some aspect of the Māori situation must be taken into account. ${ }^{40}$

Tino rangatiratanga upholds the entitlement of Māori to a measure of autonomy to manage their own policy, resources, treasured possessions and affairs. ${ }^{41}$ The principles of the Treaty provide a framework for developing practical responses to Māori health, cultural property rights and intellectual knowledge. The principle of partnership is central to the Treaty, involving an exchange of rights and obligations. The partnership principle requires that the Crown and Māori act reasonably and in good faith in their interactions, taking into account the evolving nature of the relationship. The Crown must actively protect the Treaty rights of Māori and not encroach upon the exercise of tino rangatiratanga. Agencies should seek to involve iwi, hāpu and Māori organisations in policy development and priority setting. The Crown must actively protect the social, economic and cultural well-being of Māori. The Treaty partnership requires that Māori remain able to protect their cultural practices and their tikanga and to participate fully in New Zealand society as Māori.

\footnotetext{
${ }^{38}$ See the discussion in chapter 7.

${ }^{39}$ Such as the Treaty of Waitangi Act 1975; Environment Act 1986; Resource Management Act 1991; Crown Minerals Act 1991.

${ }^{40}$ The New Zealand Public Health and Disability Act 2000, was controversial because of provisions mentioning the Treaty of Waitangi, specific Māori health needs, and specific representation on health boards.

${ }^{41}$ Waitangi Tribunal Murwhenua Fishing Report (Waitangi Tribunal, Wellington, 1988) 187; Waitangi Tribunal Mangonui Sewerage Report (Waitangi Tribunal, Wellington, 1988) 187; Waitangi Tribunal The Taranaki Report (Waitangi Tribunal, Wellington, 1996)17-21.
} 
Consequently, it is vital that the proposed New Zealand legislative framework does not conflict with the principles established as a result of the Treaty. Treaty implications regarding human tissue have yet to be determined, but the Crown's obligation to protect the Māori people and culture guarantees the right of Māori to determine how body parts and tūpāpaku are treated. ${ }^{42}$ Consequently, compulsory acquisition of body parts is likely to be offensive ${ }^{43}$ and consultation is essential prior to the adoption of any proposed framework. Ethics committees must recognise and respect the sensitivity of certain types of research.

\section{Human Tissue Concepts}

At least four key Māori concepts are involved when debating the use of human organs or tissue. These are Tapu, Mauri, Whakapapa and Kaitiakitanga.

\section{$1 \quad$ Tари}

Tapu is the underlying spiritual concept, encompassing many sources of harm that might arise from inappropriate use of body parts. Tapu is the web of observances and rules that overlays and binds this world and the next world. Tapu ensures consistency and safety for those who comply with, and respect, its rules.

As stated by Lewis and Pickering: ${ }^{44}$

Organ donation tears at the fabric of tapu. To seek to retain the life of an individual by the removal of organs from someone who has died creates an interplay between the living and the dead that may upset the spiritual order, lineages or whakapapa, and the spiritual elements of mauri and hau are intermingled through an unnatural process. The spark of life is transferred by human will, not by divine order. Where tapu is broken the implications are often unknown. Spiritual retribution, manifested in the spirit or physical world could befall donor and/or recipient and affect either party's whanau. It is possible that these are considerations that are for some great enough to outweigh the benefits of either donating or accepting organs.

Mauri, or the physical life force, has been described as one of the fundamental spiritual concepts that permeate all relationships Māori have with each other and with the natural world. ${ }^{45}$ The traditional Māori view is that everything in the natural world possesses mauri, including people, plants, animals, genetic material and physical entities, such as lakes, rivers and rocks. Mauri is a special power which makes it possible for everything to move and live in accordance with the conditions and limits of its existence. Barlow observes that when a person is born, the gods bind the body and spirit together. ${ }^{46}$ Humans possess mauri-ora, which is of a higher order

\footnotetext{
${ }^{42}$ Te Puni Kōkiri Hauora o te Tinana me ona Tikanga (Te Puni Kōkiri, Wellingon, 1999).

${ }^{43}$ See chapter 2 relating to consent for the harvest of organs from the dead and chapter 3 relating to the "Guthrie test" samples. The heart retention at Green Lane Hospital was especially offensive to Māori parents- see chapter 2.

${ }^{44}$ Greg Lewis and Neil Pickering "Māori Spiritual Beliefs and Attitudes towards Organ Donation" (2003) NZ bioeth j 31, 34.

${ }^{45} \mathrm{~N}$ Gibbs Genetically Modified Organisms and Maori Cultural and Ethical Issues Commissioned by the Ministry for the Environment (Government Print, Wellington, 1998).

${ }^{46}$ C Barlow Tikanga Whakaaro: Key Concepts in Maori Culture (Oxford University Press, Auckland, 1991).
} 
than mauri and, in addition, requires humans to assume responsibility towards the environment. Emerging biotechnologies that involve tampering with genes are seen as unnatural and may change the spiritual essence of being Māori as kaitiaki ${ }^{47}$ over the cultural, social, physiological and environmental aspects of the genetic encoding of te ao Māori.

\title{
$3 \quad$ Whakapapa
}

Mauri and each life-form, including humanity, are linked together by whakapapa, through mutual descent. Whakapapa provides the generational link, which ensures the continuity of the three fundamental social units of Māori: whānau, hapu $\bar{u}$ and iwi. The concept is one of laying one thing upon another, as with one generation upon another. Living things and inanimate objects such as soil, rocks and mountains have a whakapapa. Mead states: ${ }^{48}$

\begin{abstract}
In stark contrast to the Western concept of isolating a human gene from any broader identity, for Māori, the physical human gene is inextricably linked to the metaphysical whakapapa, that is, the direct heritage from ancestors which must be transmitted to descendents. The general perception would be of considering human genes as collective cultural property and not the property of an individual. Western science, however would tend to argue quite the opposite and stress the uniqueness and very individuality of human genes.
\end{abstract}

As the mauri of all living things is connected, any action that changes or degrades the essence of one life form has an impact on the integrity of all other life. Mead states that the human gene contains a life force, which cannot be separated or isolated as an entity devoid of life. "Isolation, reproduction or manipulation of the physical gene would not alter the perception by Māori of the whakapapa and mauri inherent and inextricable from the gene." ${ }^{, 49}$ To alter the genetic material is to alter the blood of the ancestors, thus altering the whakapapa relationship, by changing or introducing new blood that may impact on the other rights of authority, status and control that are passed down. Genetic research has the potential to individualise choice, which conflicts with Māori expressions and understandings of collective relatedness.

Organ transplantation may result in a perception that the blood line has been diluted, or even contaminated. An organ from an unknown source makes interconnections within the whānau less certain and whakapapa is no longer only connected to certain tipuna. Other individuals would have a part of their lineage present in the recipient and, consequently, in the whānau.

As stated by Lewis and Pickering: ${ }^{50}$

With a "foreign" organ in the body, recipients are no longer made up of the material only of their tipuna or ancestors. They also possess a foreign element, an

\footnotetext{
${ }^{47}$ Guardian.

${ }^{48}$ Aroha Te Pareake Mead "Human Genetic Research and Whakapapa" in P Te Whaiti, M McCarthy and A Durie (eds) Mai I Rangiatea: Maori Wellbeing and Development (Auckland University Press \& Bridget Williams Books, Auckland, 1997) 126, 128.

${ }^{49}$ Mead, above, 128.

${ }^{50}$ Greg Lewis and Neil Pickering "Māori Spiritual Beliefs and Attitudes Towards Organ Donation" (2003) NZ bioeth j 31, 34.
} 
unquantifiable, unknown element of an ancestral line that is alien to their own. This issue is likely to be highlighted by the practice of anonymous donation. For some organ recipients this may create a feeling of alienation or isolation from whanau, iwi and tipuna. In possessing spiritual connections with another whanau through a donated organ, an individual's connection with their whanau as a whole may be weakened. And just as the individual's sense of being part of a whole will diminish, so the sense of other individuals of the whole of which that individual is a part may also be affected.

Kaitiakitanga is the exercise of guardianship by the tangata whenua of an area, in accordance with tikanga Māori, to protect and care for the environment and heritage. The purpose is to ensure the protection of the mauri of all things. Māori are concerned to maintain guardianship rights, to ensure the non-interference with their multi-generational whakapapa. There is a customary obligation on individuals to assume this responsibility, including the cultural imperative that human remains must be returned to their place of origin and must be buried, or otherwise left to rest. Thus, the storage of human materials in institutions, particularly outside the area of collection, is culturally unacceptable. As stated by Mead: "Storage and eventual repatriation are ethical issues as significant to Māori as collection and usage.",51

\section{CONSULTATION}

The proposed framework would require consultation to determine Māori views and preferences prior to its introduction. Such consultation is an integral part of a Treaty-based approach. "Consultation should occur at various levels: with iwi, hāpu and Māori organisations, and with individuals and whānau as patients or clients." 52 Several guidelines on consultation have been prepared. ${ }^{53}$ These emphasise that consultation must involve a spirit of goodwill and open-mindedness and requires:

- $\quad$ reasonable time for consultation to occur;

- $\quad$ sufficient information to enable a committed response; and

- $\quad$ genuine consideration of the views of consulted groups.

The dubious benefit of some consultation is shown by the decision of the Environmental Risk Management Authority (ERMA) to allow cows to be bred to produce milk containing human myelin basic protein. Bleakley ${ }^{54}$ demonstrates the difficulties arising from what Goddard J referred to as "... the collision between spiritual belief and scientific understanding." ${ }^{.5}$ This conflict is likely to be

\footnotetext{
${ }^{51}$ Mead, above, 131.

${ }^{52}$ Ministry of Commerce Maori and the Patenting of Life Form Inventions. An information paper produced by the Patenting of Life Forms Focus Group (Putahi Associates for the Ministry of Commerce, Wellington, 1999) <http://www.moc.govt.nz> (last accessed 25 March 2003) 8.

${ }^{53}$ Parliamentary Commissioner for the Environment Proposed Guidelines for Local Authority Consultation with Tangata Whenua (Parliamentary Commissioner for the Environment, Wellington, 1992); Responsiveness Unit, State Services Commission, Partnership Dialogue: A Mãori Consultation Process (State Services Commission, Wellington, 1989); Te Puni Kōkiri A Guide for Departments on Consultation with Iwi (Te Puni Kōkiri, Wellington, 1993).

${ }_{54}^{54}$ Bleakley v Environmental Risk Management Authority [2001] 3 NZLR 213, 286 (HC).

${ }^{55}$ Bleakley v Environmental Risk Management Authority, above, 286.
} 
dominated by scientific imperatives, because of the greater ability to demonstrate the potential consequences of scientific endeavours, compared with the effects of cultural damage.

\section{ISSUES OF IMPORTANCE TO MĀORI RELATING TO HUMAN MATERIALS}

\section{Organ Transplantation}

New Zealand has one of the lowest organ donation rates in the developed world. ${ }^{56}$ However, it has been argued that the comparative measure of donation performance by way of the number of donors per million of population is scientifically flawed, because assessment of organ donation from the deceased, by reference to a census of the living, does not provide an analysis of a comparison of the number of actual organ donors with the number of deceased potentially suitable donors. ${ }^{57}$ A more accurate assessment would be achieved by conducting death record interviews, to determine organ donation potential. The percentage of those potential donors who were converted into actual donors is a better measure of organ donation effectiveness.

Māori appear to be less likely to be either organ donors, or organ recipients, than non-Māori. ${ }^{58}$ From 1996-2000 3.5\% of donors were Māori. As the 2001 census statistics indicate that one in seven people identify as Māori, this indicates that Māori are under-represented per capita in donation statistics. The low rate reflects cultural objections by some Māori, but may also reflect discomfort with the concept of brain death, ${ }^{59}$ mistrust of medical staff and historical concerns about the retention of organs and tissues at autopsies. ${ }^{60}$

Māori most commonly need kidney transplants, because of their high rate of diabetes. ${ }^{61}$ Although Māori total approximately 30 per cent of the dialysis population, they receive approximately 10 per cent of the transplants performed. Māori are also the main group requiring bone marrow transplants. ${ }^{62}$ The requirement to match tissue type for bone marrow transplantation restricts the availability of donors, because Māori ethnic uniqueness. The number of Māori on bone marrow donor panels is low and the large donor pools in the United States and Europe are not likely to provide a match. ${ }^{63}$

\footnotetext{
${ }^{56}$ In 2005, the rate per million of population was 8. There were 29 donors. Organ Donation: The Gift of Life <http://www.donor.co.nz> (last accessed 14 October 2006).

${ }^{57}$ Richard S Luskin and Francis L Delmonico "Assessing Organ Donation from the Dead Should Not be done by Reporting a Census of the Living" (2003) 3 American Journal of Transplantation 1185.

${ }^{58}$ Australian and New Zealand Organ Donation Registry 2002 Annual Report of the Australian and New Zealand Organ Donation Registry <http://www.anzdata.org.au> (last accessed 17 March 2005).

${ }^{59}$ See the discussion in chapter 4.

${ }^{60}$ See the discussion in chapter 2.

${ }^{61}$ The Māori rate of death from kidney-related disease is four times greater than for non-Māori .Te Puni Kōkiri Hauora o te Tinana me ona Tikanga (Te Puni Kōkiri, Wellingon, New Zealand, 1999)14. Matthew Torbit "Maori 'facing extinction' from Diabetes" (14 November 2006) The Dominion Post Wellington A1.

${ }^{62}$ Te Puni Kōkiri, above, 14.

${ }^{63}$ Te Puni Kōkiri, above, 15.
} 
Commentators have questioned the justice of permitting access to the limited supply of organs by members of groups that are unwilling to donate. It is practically and morally justifiable to limit the provision of cadaveric transplants to foreign nationals, despite the advantages in entering into organ sharing arrangements with other countries, because of the small New Zealand population. Some countries have refused to allow other countries to participate in such schemes, unless there is sufficient reciprocity. For example, the nations of the European community, through the auspices of the Council of Europe, co-operate in an organ-sharing network, they have excluded countries with a low rate of organ donation. These countries did not contribute a fair share, and so their citizens were ineligible to receive organs from the common pool. ${ }^{64}$

However, it is harder to justify similar action with regard to particular groups in a community. To select them on ethnic, racial or religious grounds is discriminatory. In any event, individuals not groups need organs. Even if it could be identified that Māori, as a group, donate organs at a lower rate than others, Māori are highly diverse and it is impossible to extrapolate that data to the individual who needs a transplant, as that individual may not share the reluctance. In addition, a person can simultaneously belong to several groups, such as being a woman, a mother a teacher, and so on. Each of these groups, if considered separately, might show different rates of group donation. Rhodes stated: "There is no principled way to determine which group identification gets used for ruling individuals ineligible for a cadaveric organ." 6

Additionally, a person needing an organ is likely to have increased awareness and knowledge about organ donation and thus may be prepared to donate organs. These factors indicate that although it is morally acceptable to encourage donation, and perhaps provide incentives, ${ }^{66}$ it would not be acceptable to impose sanctions on individuals because they might not be willing to donate, or because they belong to a group that has a statistically low rate of organ donation.

In considering the use of body organs or tissue, there are three distinct issues that Māori may view differently from other population groups; firstly, the donation of material from living donors, secondly, harvest from the dead and thirdly, the collection of material for research purposes.

\section{$1 \quad$ Living donation}

The living donor and recipient often have a close familial relationship. Although histocompatibility is less important for kidney transplantation than for other organs, the parties commonly have some emotional tie. Living donation within a whānau may be more acceptable for Māori than between strangers, as threats to whakapapa are reduced. Māori value kinship, as stated by Rangihau: "There is as much joy-or perhaps greater joy-in giving as in receiving. And so we give of one

\footnotetext{
${ }^{64}$ Rosamond Rhodes "Organ Donation" in Helga Kuhse and Peter Singer (eds) A Companion to Bioethics (Blackwell Publishers Ltd, Oxford, 1998) 335.

${ }^{65}$ Rhodes, above, 336.

${ }^{66}$ See the discussion on commercialisation in chapter 1.
} 
another to one another." ${ }^{67}$ Prior to the arrival of Pakeha, Māori lived in a tribal kinship society, involving an intricate set of relationships relating to "gift-giving" ${ }^{6}$ There was great spirituality implicit in gift exchange and reciprocity. Traditional Māori society is said to have been underpinned by an "economy of affection", as contrasted with the "economy of exploitation" introduced as a consequence of colonisation. ${ }^{69}$ The emphasis on giving and sharing suggests that, with greater awareness of the need for organs to assist and support the family group, together with efforts to improve trust in the medical establishment, the rates of donation might be increased.

However, factors that may inhibit living donation between strangers are the intermingling of whakapapa with resulting disturbances of ancestral lineages, and the ramifications of such disruption for individual and whānau.

\title{
$2 \quad$ Organs from deceased donors
}

Most Māori have an attitude to death that requires that the dead are cared for, cherished, mourned, spoken to and honoured. Most still choose burial, rather than cremation. They want to see their dead and have them with them. Very few leave the dead in an undertaker's chapel until the funeral. In part, this closeness with the dead may contribute to the reluctance to donate organs. Additionally, the appearance of a brain dead person on life support is such that the intuitive response of family members may be that the person is alive, even if they intellectually accept the medical advice that the person is dead. ${ }^{70}$

In traditional Māori belief, the wairua begins to leave the body at death. This wairua may be affected by actions taken with respect to the body following death. The belief is that death is a process, rather than an event occurring at a specific point in time. Lewis and Pickering explain: ${ }^{71}$

\begin{abstract}
The wairua must undergo a transformation of understanding and go through a process of becoming part of the next world. This is reflected in the Māori Tangihanga, or funeral ceremonies, that often last for three or more days. The wairua is believed to leave the body upon death, but to come and go from the corpse as it slowly ventures out to explore the newly discovered spiritual realm.
\end{abstract}

The removal of organs during the course of this process is considered disrespectful to the wairua and may deleteriously effect the wairua's preparation for the journey to Te Pō, the final resting place.

Another possible source of harm to the wairua is through the hau of the deceased person, which might imbue the organ. The hau is a mixture of personality and aura, or self-presence. It is no longer generated after death, but during life it

\footnotetext{
${ }^{67}$ John Rangihau "Being Maori" in Michael King (ed) Te Ao Hurihuri: The World Moves On (Hicks Smith \& Sons/Methuen NZ Ltd, Auckland, 1977) 166.

${ }^{68}$ M Mauss The Exchange of Gifts W D Halls (trans) (Routledge, London, 1990).

${ }^{69}$ M Henare "Human Labour as a Commodity- a Maori Ethical Response" in Victoria University of Wellington Department of Geography Labour Employment and Work in New Zealand (Victoria University, Wellington, 1995).

${ }^{70}$ See the discussion of brain death in chapter 4.

${ }^{71}$ Greg Lewis and Neil Pickering "Māori Spiritual Beliefs and Attitudes Towards Organ Donation" (2003) NZ bioeth J 31, 33.
} 
exists within and around the body, so a person may leave hau in anything they come in contact with. Consequently, traditional Māori protected anything derived from the body, such as fingernails, placenta or hair cuttings. Lewis and Pickering state: ${ }^{72}$

The fear in the case of organ donation would be that a donated organ could fall into the wrong hands and be used in some way against the individual after his or her death.

Although donated tissue or body parts can be life-saving for individuals, it is essential that the spiritual well-being, as well as the physical well-being, of the recipient is considered. The recipient may suffer adverse effects relating to the spiritual element transplanted with the organ, rather than any physical consequences. This could spread from the organ and consume the recipient, effectively poisoning the recipient with the same spiritual element that killed the donor. If an organ continues to live after the donor is dead, the mauri of the donor may interact with the mauri of the recipient. Similarly, the hau of the donor may be imprinted on the organ and be mixed with the hau of the recipient. The blessing of the organ, by karakia ${ }^{73}$ prior to the transplantation, may promote the well-being and health of the recipient.

It is unclear to what extent Māori values are amenable to change, although many who are reluctant to donate or receive organs suggest that they might have different views if the procedure was to save a loved one. The Bioethics Council has discovered in its dialogues with Māori that the core values about the implications of biotechnology for tikanga, matauranga, whakapapa and the role of tohunga are seldom articulated. It suggested that thinking in these areas may be evolving, stating: "This in turn raised diverging views about the nature of tikanga itself and the extent to which it is an immutable body of tradition or custom, or a spectrum of everchanging practices.", 74

The Auckland District Health Board Review Panel concluded that with respect to tissue or organs being used after death, the prior informed consent of the deceased person should prevail over the express objections of family members and should be respected. ${ }^{75}$ This might have the effect of increasing the availability of such tissue or organs, but the consequence might be a loss of trust in the medical establishment, as well as cultural offence to Māori and other groups in the community. The public attention that might result from distressing altercations between families and the medical establishment could have a negative impact on donation rates, as potential donors could withhold consent out of deference to family sensibilities.

However, despite these concerns the structure proposed in this thesis would provide a means for sources to make binding dispositions of their cadaver, because the benefit from increased donation rates outweighs the risk of cultural offence. Consequently, the consent of the source must be fully informed and consideration

\footnotetext{
${ }^{72}$ Lewis and Pickering, above, 33.

${ }^{73}$ Prayer.

${ }^{74}$ Toi te Taiao: The Bioethics Council The Cultural, Ethical and Spiritual Aspects of Animal-toHuman Transplantation (Bioethics Council Wellington 2006) 20. The Bioethics Council recommended an intra-cultural dialogue process to address tikanga and spiritual ethical and cultural issues within te ao Māori.

${ }^{75}$ The Human Tissue Act 1964 is considered further in chapters 3 and 8.
} 
given to all the wider interrelated factors. ${ }^{76}$ This thesis suggests that representatives must carry out the instructions of the source regarding the disposition of the body and their decisions will trump the views of the whannau. However, the source could choose to instruct the representative to follow tikanga. Similarly, living persons who want decision making in a collective manner can make arrangements accordingly.

\section{B Uses of Biological Materials}

Māori assert that their intellectual property in traditional knowledge, taonga and images is being unjustifiably appropriated. The Wai 262 Claim $^{77}$ is a Treaty of Waitangi claim brought against the New Zealand Crown in 1991 by the members of six iwi. ${ }^{78}$ Wai 262 generally asserts exclusive and comprehensive rights to flora and fauna, cultural knowledge and property, as taonga protected by Article Two of the Treaty of Waitangi. The claimants assert that the Crown has:

- $\quad$ Failed to actively protect the exercise of tino rangatiratanga and kaitiakitanga by the claimants over indigenous flora and fauna and other taonga, and also over mātauranga Māori ${ }^{79}$;

- $\quad$ Failed to protect the taonga itself;

- Usurped tino rangatiratanga and kaitiakitanga of Māori in respect of flora and fauna and other taonga, through the development of policy and the enactment of legislation; and

- $\quad$ Breached the Treaty of Waitangi by agreeing to international agreements and obligations that affect indigenous flora and fauna and intellectual property rights and rights to other taonga.

The Crown has attempted to distil the broad scope of the Wai 262 claim into four categories:

- The protection and retention of Mātauranga Māori (traditional knowledge).

- Māori cultural property (tangible manifestation of mātauranga Māori) as affected by the failure of legislation and policies to protect existing Māori collective ownership of cultural taonga and to protect against its exploitation and misappropriation.

- $\quad$ Māori intellectual and cultural property rights - as affected by New Zealand's intellectual property legislation, international obligations and proposed law reforms. Issues include the patenting of life form inventions and the inability of intellectual property rights to protect Māori traditional knowledge and cultural property.

\footnotetext{
${ }^{76}$ See the discussion in chapters 2 and 8.

${ }^{77}$ The claim was the 262nd claim lodged with the Waitangi Tribunal and, as a result, is colloquially known as "Wai 262".

${ }^{78}$ Ngāti Kuri, Ngāti Wai, Te Rarawa, Ngāti Porou, Ngāti Kahungunu and Ngāti Koata.

${ }^{79}$ Māori traditional knowledge.
} 
- $\quad$ Environmental, resource and conservation management - including concerns about bio-prospecting, biotechnological developments involving indigenous genetic material, ownership claims to resources and species, and Māori participation in decision making.

These claims are similar to those being asserted by indigenous people around the world with regard to intellectual property rights, laws and international agreements. These are currently being considered in international fora, including the World Trade Organisation, the World Intellectual Property Organisation, and the Convention on Biological Diversity.

The concerns raised in the second category relate to the fundamental differences between Western intellectual property rights and traditional knowledge protection mechanisms of indigenous peoples. For example, intellectual property rights are usually limited in duration and involve disclosure to the public and the eventual contribution to the public domain. ${ }^{80}$ The philosophy is the exploitation, rather than protection, of information and innovations. In many cases, indigenous peoples seek protection in perpetuity and do not want sacred-secret information to be disclosed to the public.

Intellectual property rights also do not provide the protections that indigenous people seek because of the criterion of novelty and the requirement to identify an individual (or commercial entity) as the author/creator of a work or innovation in whom to vest intellectual property rights. In comparison, the rights that indigenous people assert are collective, not individual, in nature. Traditional knowledge and traditional knowledge-based innovations and practices may be developed incrementally over generations. ${ }^{81}$

Māori are seeking a Tikanga Maori Framework of Protection, ${ }^{82}$ which would be owned and controlled by Māori, based on tikanga Māori, reflecting Māori cultural values and ethos, and be sufficiently flexible to take into account issues that affect Māori at national, regional and local marae levels. ${ }^{83}$ They are suspicious that their biological materials may be used for purposes that benefit neither them, nor Māori as a group. This viewpoint may vary according to the proposed uses. For example, Mead states that most Māori would distinguish the use of gene therapy to help save the life of a critically ill person from uses such as genetic screening. ${ }^{84}$

\footnotetext{
${ }^{80}$ See chapter 7.

${ }^{81}$ The World Intellectual Property Organisation Intergovernmental Committee on Intellectual Property and Genetic Resources, Traditional knowledge and Folklore is currently considering how intellectual property laws might be adapted to address some of these concerns about collective ownership and the duration of protection.

${ }^{82}$ Maui Solomon "Intellectual Property Rights and Indigenous Peoples Rights and Obligations" (Paper presented at Global Biodiversity Forum 15 UNEP Headquarters, Gigiri, Nairobi, Kenya May 2000). $<$ http://www.inmotionmagazine.com/ra01/ms2.html > (last accessed 15 March 2003).

${ }^{83}$ Solomon, above.

${ }^{84}$ Aroha Te Pareake Mead "Human Genetic Research and Whakapapa" in P Te Whaiti, M McCarthy and A Durie (eds) Mai I Rangiatea: Maori Wellbeing and Development (Auckland University Press \& Bridget Williams Books, Auckland, 1997) 126, 130.
} 
Durie states that, at regional and national hui held to debate genetic modification, there was overall distrust in genetic modification. However, he adds: ${ }^{85}$

[A]t most hui a few respondents were adamant that Māori had the right to full access to medical advancements and new technologies, including those that resulted from genetic modification and saw in that process potential health gains for Māori. They urged an open mind.

$1 \quad$ Research

Research using Māori body parts raises key issues, such as:

- Who makes the decisions with respect to medical research?

- Who controls and plans medical research?

- Is it possible to structure "group rights" or "group consent"?

Research is carried out for many different purposes. Some of these are aimed specifically at saving lives, or easing human distress, but much research is aimed at developing new technologies and pharmaceutical products. The aim is often as much commercial as compassionate. As stated by Mead: ${ }^{86}$

Māori and other indigenous peoples have strong cultural traditions which seriously question the ethics and protocols governing the profit-making framework in which a high proportion of genetic research is currently being pursued.

She indicates that there is strong suspicion that Māori might be the subjects of research from which they experience little advantage. She is also concerned that, without adequate safeguards, ethical values and procedures may be disregarded in light of commercial benefits flowing from research. In particular, ethical guidelines that constrain research in New Zealand may have little effect on overseas research partners and may prove impossible to enforce.

The main stages of research are research, process and product. The research stage involves the selection of the original or existing material from which the inventor intends to derive new genetic components or life-forms. The inventor requires access to the original life-form in order to carry out this research. If human material is used, this must be obtained from individuals. The Ministry of Commerce states that Māori issues at the research stage include: ${ }^{87}$

- Rangatiratanga. The exercising of the rights and responsibilities to determine the use of taonga species according to Māori cultural values;

- $\quad$ Access. The right to control access to these resources and their use as material for research;

\footnotetext{
${ }^{85}$ Mason Durie “Mana Tangata: Culture Custom and Transgenic Research” Deputy Vice-Chancellor's Lecture, Massey University, Wellington, 5 August 2003, 7.

${ }^{86}$ Mead, above, 127.

${ }^{87}$ Ministry of Commerce Maori and the Patenting of Life Form Inventions. An information paper produced by the Patenting of Life Forms Focus Group (Putahi Associates for the Ministry of Commerce, Wellington, 1999) < http://www.moc.govt.nz> (last accessed 25 March 2003).
} 
- $\quad$ Appropriateness and morality. The right to decide what uses and associations are acceptable in light of the taonga status of the life-form and Māori cultural beliefs about their relationship to natural resources;

- Informed consent. Ensuring that indigenous people whose genetic material is used for research are fully informed about the intentions of the researchers and give consent to these purposes;

- Acknowledgement. Recognition of the origins of the life-forms, the status of the iwi with rangatiratanga over them, and the interests Māori have in their preservation.

At the process stage, technological processes might be used to alter, extract or manipulate the material, with the objective of producing a new life-form, or modifying an existing life-form. For example, genetic engineering involves the transfer of genes from one organism to another. Māori issues at this stage include:

- Deciding whether the process is appropriate in light of Māori cultural values;

- Maintaining the whakapapa in ensuring the integrity of ancestral authority rights that pass down to descendants; and

- $\quad$ Protecting Māori traditional knowledge and processes.

At the product stage, the research is applied to produce a newly discovered or invented life-form. Such products might include genetically engineered new life forms, or genetic components of life forms, such as tissues, cells, genes, or enzymes. Issues arising at this stage include:

- Recognition of the origins of the original natural life-forms, the status of iwi holding rangatiratanga over them, and the involvement of Māori in their long term protection;

- $\quad$ Equitable sharing of the benefits obtained from commercial use of the new product, in light of the initial derivation from the naturally occurring taonga owned and cared for by the iwi;

- $\quad$ Risk to the original life-form, by the release of the modified form;

- Disruption to traditional knowledge, which may be undermined by the introduction of genetic varieties with different properties from the original species from which they originated.

Mātauranga Māori have opposed genetic modification, because of risks to the environment, human dignity, the special place that humans hold in the wider universe and the relationships between people and other forms of life. As stated by Durie: "...[I]n the GM debate the concern is that the microscope will fragment strands of DNA and in the process lead to a splintering of human inviolability." ${ }^{88} \mathrm{He}$ suggests that there are many parts to the debate, including economic gain, opportunities for New Zealand researchers, research credibility, retaining New Zealand as a green paradise and maintaining a Treaty conscience. ${ }^{89} \mathrm{He}$ opines that the lack of reconciliation of opinions in this area is, to some extent, because there is no methodology that can transcend the philosophies inherent in different bodies of

\footnotetext{
${ }^{88}$ Mason Durie “Mana Tangata: Culture Custom and Transgenic Research" (Deputy Vice-Chancellor's Lecture, Massey University, Wellington, 5 August 2003) 5.

${ }^{89}$ Durie, above, 5 .
} 
knowledge, and that this conflict is unlikely to be fully resolved by way of legislation.

\section{Genetic modification}

Many generic concerns were expressed in the submissions to the Royal Commission on Genetic Modification, but some were specific to Māori. Included in these were philosophical objections, such as clashes with Māori world views, cultural concepts and tikanga. Treaty of Waitangi issues included intellectual property rights and Māori inclusion in decision making. Some Māori perceived economic benefits or the possibility of new treatments for particular diseases, such as diabetes.

Of the 200 submissions to the Royal Commission relating to Māori, 32 per cent focussed on the Treaty of Waitangi and the need for an active role for Māori in decision making, 24 per cent related to ownership and intellectual property rights over indigenous flora and fauna, while 13 per cent opposed any transfer of genes between humans and animals. The greatest number of submissions, 64 per cent, submitted that genetic modification was unacceptable, because it was contrary to Māori custom and philosophy. ${ }^{90}$

\section{$3 \quad$ Informed consent}

Scientists collecting tissue for research sometimes refer to indigenous people as "carriers of genetic information", "subjects", or "data sets", and consider them incapable of understanding the reasons for genetic testing, or exercising informed choice. ${ }^{91}$ Researchers have struggled to formulate mechanisms through which consent can reasonably be obtained. The individualistic premises underlying the concept of informed consent are often difficult to translate to non-western cultures. The UNESCO Declaration provides that "The importance of cultural diversity and pluralism should be given due regard." 92 It also states that in no case should a collective community agreement or the consent of a community leader or other authority substitute for an individual's informed consent. ${ }^{93}$ These provisions were strongly criticised by Māori and Pacific people at a UNESCO conference to consider implementation of the Declaration, as imposing a western paradigm on other cultures. $^{94}$

As has been seen, the requirement to protect the whakapapa does not rest with individuals who may not have the right to give, or sell, biological materials for research without the consent of the collective group. If research affects a collective hapū, iwi, or Māori grouping, issues arise as to who within that grouping should give consent. Decisions made may affect descendants more directly than either the participants whose body materials are used for research, or the kaumātua who might approve the research. Despite this, this thesis argues that in light of the diversity of

\footnotetext{
${ }^{90}$ Durie, above, 7. Some submissions referred to more than one ground of opposition.

${ }^{91}$ Lori B Andrews and Dorothy Nelkin Body Bazaar (Crown Publishers, New York, 2001) 76.

${ }^{92}$ UNESCO Universal Declaration on Bioethics and Human Rights 24 June 2005 Article 12.

${ }^{93}$ UNESCO, above, Article 6( c).

${ }^{94}$ UNESCO Ethics of Knowledge Production Conference, Dunedin 12-14 February 2006.
} 
Māori and the wide variation of levels of acceptance of traditional beliefs, it is inappropriate for the law to restrict individual autonomy.

Mead, while recognising the potential for conflict within communities, states that: "The preference should be for mutually agreed consent procedures rather than legislation by the Crown." ${ }^{95}$ She asserts that the consent cannot be informed unless information on the proposed research is provided in easily understood language, in some circumstances in both Māori and English, specifying:

- $\quad$ the purposes of the research;

- $\quad$ the benefits for the donors/participants and sponsors of the research;

- the potential risks;

- $\quad$ any developments during the research that might alter the willingness of the subjects to permit the research to continue;

- the degree to which the research could affect Māori social units beyond those consenting; and

- the procedures for the collection, storage, use, and eventual return, of genetic specimens.

There is potential for conflict between Māori individuals and Māori collective social units about the acceptable limits of use of body parts. ${ }^{96}$ Henare has stated that this situation is exacerbated by tribal essentialism, the increasing fragmentation of an already minority population into tribal groups, which compete with each other for limited resources upon which to base economic and cultural development. ${ }^{97} \mathrm{Mead}$ states: "Even if an informed consent procedure is developed, there still remains the question of who has the right to give consent to research which could affect a wider collective." 98 Neo-tribalists claim that tribal knowledge is the property of the tribe, asserting: ${ }^{99}$

[O]nly those that belong to that kinship group can access, critique, debate or comment upon the tribal knowledge and learning pertaining to that group. Some go so far as to assert that the idea of Maori as a collective identity is no longer valid, that only the tribal identity matters.

If an individual chooses to exercise personal autonomy and give consent to a procedure, should a collective unit be able to overrule this decision? This thesis proposes a property interest in body parts, which is an individualistic concept, although it does not constrain the ability of individuals to choose to make collective decisions. This individualism is balanced by Māori being involved in review of proposed research, as they have a collective interest in research that could impose risks on all the members of a socially identifiable group. The process may involve

\footnotetext{
${ }^{95}$ Aroha Te Pareake Mead "Human Genetic Research and Whakapapa" in P Te Whaiti, M McCarthy and A Durie (eds) Mai I Rangiatea: Maori Wellbeing and Development (Auckland University Press \& Bridget Williams Books, Auckland, 1997) 126, 137.

${ }^{96}$ Ella Henry and Hone Pene "Kaupapa Maori: Locating Indigenous Ontology, Epistemology and Methodology in the Academy" (2001) 8 Organization 234.

${ }^{97}$ M Henare "Te tangata, te taonga, te hau: Maori Concepts of Property" (Paper presented to the Conference on Property and the Constitution, Wellington, for the Laws and Institutions in a Bicultural Society Research Project, Waikato University, 18 July 1998).

${ }^{98}$ Mead, above, 139.

${ }^{99}$ Henry and Pene, above, 240 (emphasis in the original).
} 
wananga around the processes and purposes of the research and the acceptable limits and controls.

Conflict is less likely if the collective viewpoint is exercised at the level of approval of the research, rather than at the point of collection of the research materials from individual donors. ${ }^{100}$ This moves beyond the need for consent from the research participants and consideration of individual risk and benefit, to consideration of risks to the group as a whole. The problem is devising a mechanism by which an entire group can be involved in research review, in a morally meaningful way. ${ }^{101}$ Unless a referendum of the group was conducted, the only alternative would be some form of representative involvement. As stated by Jeunst: ${ }^{102}$

To seek out representatives of the population group in non-representative ways is no better than recruiting stray individuals: it still denies the unconsulted members of the group a bona fide voice in the discussion, and opens up the process to charges of "forum shopping"- the "morally problematic" practice of seeking out population spokespeople and research participants whose positive response to a research plan can be predicted in advance.

Māori ethics committee membership does not necessarily resolve this difficulty, especially where the committee members are appointed by government. If they were selected by their community and required to represent its views then, arguably, they are empowered to make decisions on its behalf. ${ }^{103}$

Dodson and Williamson assert: "History teaches us that the pure fascination of science cannot be quarantined from its broader social implications." ${ }^{104}$ It may be culturally offensive to exploit the biological material of Māori to generate profit for multinational corporations, especially if it involves the immortalisation of blood cells. The commercial potential must be made clear to the sources at the time of consent. Scientists see human tissue as a replenishable resource, while critics see people being used as raw materials for commercial products, or as data sets for research. Scientists see such research as a means to ensure that non-Caucasian people benefit from future biomedical advances, but critics believe it is exploitative of indigenous people and appropriates their heritage. For example, in the United States, litigation has been commenced by the Havasupai, ${ }^{105}$ because blood they had donated in the 1960's for diabetes research was allegedly subsequently used for unconsented research into schizophrenia, inbreeding and migration. ${ }^{106}$

\footnotetext{
${ }^{100}$ For example, the Foundation of Research, Science and Technology assesses all applications for funding for meaningful collaboration with Māori.

${ }^{101}$ See the discussion in chapter 8.

${ }^{102}$ Eric T Jeunst “Commentary: What 'Community Review' Can and Cannot Do" (2000) 28 J law med ethics $52,53$.

${ }^{103}$ See the discussion on ethics committees in chapter 8 .

${ }^{104}$ Michael Dodson and Robert Williamson "Indigenous Peoples and the Morality of the Human Genome Diversity Project” (1999) 25 J med ethics 204, 206.

${ }^{105}$ A small Indian nation in Northern Arizona with about 650 members.

${ }^{106}$ Havasupai Tribe v. Arizona State University 3:04-CV-1494 (D Ariz); Tilousi v Arizona State University 3:04-CV-1290. The research suggested that the people had migrated to Arizona from Asia, which was offensive to the tribe who believe that the Grand Canyon is the birthplace of the human race. Additionally, it is alleged that the schizophrenia research is stigmatising. Paul Rubin "Indian Givers" (27 May 2004) Phoenix New Times <http:www.phoenixnewtimes.com> (last accessed 12 October 2006).
} 
As stated, Māori value the potential to develop new medical treatments, but some genetic research is culturally offensive. The cases considered below demonstrate the difficulty of weighing intangible considerations, such as cultural offence, against potential scientific benefit and the difficulties in determining who should be consulted and the weight to be given to the views of those consulted.

\section{A The Transgenic Sheep}

PPL Therapeutics applied to ERMA ${ }^{107}$ to field test transgenic sheep with the purpose of producing a biopharmaceutical (human alpha-1-antitryspin, hAAT) ${ }^{108}$ It proposed the insertion of an artificial human gene into the mammary glands of sheep, in order to produce milk containing sufficient quantities of hAAT to treat cystic fibrosis. Māori opposition was based on a concern that mixing genetic material between species was an interference with whakapapa. ${ }^{109}$

ERMA decided that the risks to Māori culture and traditions and to their taonga were minimised by the satisfactory controls to contain the sheep and thus to prevent any affected meat or milk being consumed by humans. It decided that the possibility of a biopharmaceutical with the potential to mitigate disease and to accrue economic benefits outweighed cultural objections. ${ }^{110}$

\section{B The Transgenic Cow}

In 1998, AgResearch lodged an application to field test cattle modified by:

- $\quad$ insertion of extra bovine genes; or

- insertion of human myelin basic protein gene; or

- deletion of the bovine beta-lactoglobulin gene.

The intention was to produce milk with enhanced nutritional value that might be used as a drug to treat multiple sclerosis. ${ }^{111}$ A minority report was prepared by Ngā Kaihautu, recommending that ERMA engage in wider debate with Māori. ERMA had consulted extensively with Ngâti Wairere, the tribe in the immediate vicinity of the experimental herd, but the report stated that the issues were relevant to all Māori and a comprehensive view on the impacts on Māori values would only be possible after the issue had been debated widely.

ERMA approved the human genetic component of the research. Ngāti Wairere appealed, arguing that the authority had misdirected itself in law in terms of

\footnotetext{
${ }^{107}$ Environmental Risk Management Authority.

${ }^{108}$ Environmental Risk Management Authority Decision GMF98001 (ERMA, Wellington, 2002).

${ }^{109}$ Mason Durie "Mana Tangata: Culture Custom and Transgenic Research" (Deputy Vice-

Chancellor's Lecture, Massey University 5 August 2003) 8.

${ }^{110}$ Environmental Risk Management Authority Decision GMF98001 (ERMA, Wellington, 2002). The research was abandoned in 2003 and the 3,500 sheep were slaughtered and burned on site, together with embryos, semen and ova. Kelly Andrew "Court Rejects Sheep Review" (15 December 2004) The Dominion Post Wellington A2.

${ }^{111}$ Environmental Risk Management Authority Decision GMF98009 (ERMA, Wellington, 2002).
} 
the tests under sections 6(d) and 8 of the Act as to taonga, Māori spiritual values and the appropriate balance between these matters and other considerations under the Act. They claimed ERMA had wrongly interpreted "taonga" as being limited to tangible matters and had failed to take into account the relationship of Māori with their spiritual taonga, including the spiritual beliefs associated with the land. They submitted that the research would desecrate the land and be an offence to the values of whakapapa and mauri. The risk of metaphysical imbalance to the environment would result in risks to physical and mental health.

The High Court held that the Treaty of Waitangi imposed on the Crown a duty of active protection of taonga, including intangible beliefs. However, such duty did not require Crown action beyond what was reasonable in the prevailing circumstances. ERMA had not acted wrongfully in deciding that it would be unreasonable to give the duty a determinant weight and Māori concerns did not give rise to a right of veto. ERMA had applied their best endeavours to understand Ngāti Wairere's spiritual beliefs, even though they were unable "to assess or give weight to purely spiritual matters in the same way as they felt able to assess and give weight to purely physical matters." 112 Goddard J held that active protection under the Act may, in some cases, require decisions to be made according to the tenants of Māori spiritual belief, where these are significant, depending on the circumstances and the issues arising.

A further application was made in 2002, to develop transgenic cattle that could express functional therapeutic foreign proteins in their milk and to study gene function and genetic performance. ${ }^{113}$ The Nga Kaihautu Tikanga Taiao Report raised Māori concerns that their advice would be compartmentalised into the domain of things cultural, spiritual or intangible.

They considered that a primary issue is the identification of the Māori community with whom the authority should consult. Their view was that this is wider than that represented by Ngāti Wairere, as manawhenua of the land on which the research would be conducted. The issues include the rangatiratanga of Māori to choose to accept new knowledge and technology, by encapsulating them in tikanga Māori, thus providing for economic, social and cultural advancement, whilst remaining in accord with Māori cultural preferences. The report states that whakapapa and mauri are taonga that transcend hāpu and iwi boundaries. They apply to all living things, irrespective of species, race, ethnicity and communities. It stated that there is a need for nation-wide consultation with Māori on genetic modification and, in particular, on transgenic organisms involving human genes, in order that such decisions could be made in a fully informed manner. ${ }^{114}$

Further, although ERMA believed that the project could potentially benefit society, Crown entities have a duty to provide for mutual benefit for Māori in a manner that does not subsume Māori rights, culture and values. ${ }^{115}$ If the anticipated benefit was higher health status and longevity, there was a possibility of increasing

\footnotetext{
${ }^{112}$ Bleakley v Environmental Risk Management Authority [2001] 3 NZLR 213, 286 (HC).

${ }^{113}$ Application number GMD02028.

${ }^{114}$ Nga Kaihautu Tikanga Taiao Report on GMD02028 (Transgenic Cattle) (ERMA, Wellington, 2002) 7.

${ }^{115}$ Nga Kaihautu Tikanga Taiao, above, 5.
} 
acceptance of the technology by Māori. However, pursuit of the project, devoid of specific provision for Māori rights, culture and values was said to be a clear Treaty breach. The primary recommendation to the authority was that the application not be granted, pending further information from the Maori Generic Issues project.

ERMA approved the application, albeit in a limited form, deciding that risk of spiritual harm from the research would be low. It formulated an interpretation of mauri that differentiated between the mauri of a gene and the mauri of an organism, arguing that since the gene could not be said to be the sum total of a human, the insertion of a human gene into a cow did not amount to violating the mauri of a human, since the gene's mauri was not a human mauri and so the gene does not introduce the mauri of the human into the cow. ${ }^{116}$

Durie disputes this argument: ${ }^{117}$

\begin{abstract}
Quite apart from the dubious hypothesis that a gene can be said to possess a mauri that is separable from the mauri of the organism it serves, the ERMA analysis overlooked the fundamental starting point upon which Māori world-views are built- the relationships that confer coherence within the natural world. While scientific method often dissects the whole into smaller parts in order to find the truth, Māori philosophical methods work in the opposite direction; truth is a function of wider relationships and higher order synergies. If it were to contemplate discussion on the mauri of a gene, a Māori analysis would probably have been more concerned with the relationship of the gene's mauri to the host organism, rather than its separateness. The mauri of a gene would then be contemplated as something that only had meaning within the context of a relationship with a higher order entity. As such, it would be an essential part of the human dimension.
\end{abstract}

He suggests that it is unsatisfactory to use a framework devised to assess risk management when taking mātauranga Māori into account, and favours a framework that is linked to holistic perspectives.

\title{
VI CONCLUSIONS
}

The collection of tissue for use in the search for genetic information has become a lightning rod for broader indigenous concerns about the commercial exploitation of resources. It has become a metaphor for the highly resented intrusions that fail to respect the social meaning of the human body. The intention may be to benefit humankind, but it may also be for the achievement of profits and the acquisition of patents. Indigenous people suspect that such research is exploiting them and appropriating their property interests. ${ }^{118}$

A New Zealand framework for the control and use of human biological materials must respect Māori cultural values. It is necessary to develop an ethical and realistic way to negotiate issues such as control over research and ownership of

\footnotetext{
${ }^{116}$ Environmental Risk Management Authority Decision GMD02028 (ERMA, Wellington, 2002) 3334.

117 Mason Durie "Mana Tangata: Culture Custom and Transgenic Research" (Deputy Vice-

Chancellor's Lecture, Massey University, Wellington, 5 August 2003) 12.

${ }^{118}$ Aroha Te Pareake Mead "Genealogy Sacredness and the Commodities Market" (1996) 20 Cultural Survival Quarterly 46, 47.
} 
intellectual property. It is impractical to require that Māori be the sole beneficiaries of research utilising Māori body parts because, in that case, the resources would be unlikely to be available to pursue it, but the potential of research must be assessed within a framework encompassing Māori cultural values, as suggested by Durie. This means accepting the strong sense of common ownership and cultural identity, which may prevent an individual from parting with biological resources without group consent.

If the outcome of the research is a commercialised product, the sharing of the benefits needs to be addressed. ${ }^{119}$ Dodson and Williamson consider the relative positions of the human sources of the biological materials, the researchers and the developers of the product or patent holders and state that all three groups should share in the benefits of research. ${ }^{120}$ The focus to ensure compliance with Māori cultural values should be at the stage of approval of a research proposal, involving wananga around the research project, rather than at the point of collection of samples. Māori members of ethics committees must be selected as representatives of the collective group and be required to make decisions in accord with group preferences rather than their personal viewpoints. ${ }^{121}$ If consultation consists of little more than understanding the Māori viewpoint, there is a danger that Māori will believe that their collective interests have been appropriated. ${ }^{122}$

The Treaty of Waitangi assured a secure place for Māori values within New Zealand society, but it requires an ongoing commitment. This necessitates understanding of how tikanga Māori is practiced and applied and how integral it is to the development of Māori within the dominant European culture. Similarly, Māori need to find common ground to protect traditional values, while avoiding being sidelined from the benefits of scientific and medical developments.

As Māori are very diverse, this thesis argues that the decision making about human body parts should rest with the individual, who could chose to treat this property interest as a common asset with others, or deal with it in isolation. This is not a decision to be imposed by regulation. The choice of representative and the instructions given will be a matter for the individual. If increased rates of organ donation are perceived as a collective benefit to Māori then, with the support of kaumatua, increased awareness of the benefits may encourage donation. Studies show that community building and public education about organ donation in specific communities can be successful. ${ }^{123}$ This may be assisted by endorsement by wellknown and respected persons. ${ }^{124}$ However, any assumptions about the rationality of such world views must be avoided, as rationality is a culture specific notion and the rational thought that underlies scientific inquiry is but one form of thought. In light of the cultural significance attached to death and dying, this chapter argues that it is

\footnotetext{
${ }^{119}$ See the discussion in chapter 7.

${ }^{120}$ Michael Dodson and Robert Williamson "Indigenous Peoples and the Morality of the Human Genome Diversity Project (1999) 25 J med ethics 204, 208.

${ }^{121}$ See the discussion in chapter 8.

${ }^{122}$ However, it is noted that the notion of a single Māori viewpoint is dubious, in light of the diversity of Māori and the variation of their level of acceptance of traditional values.

${ }^{123}$ G G Persijn and A R Van Netten "Public Education and Organ Donation" (1997) 29 Transplant Proc 1614; P Miles and C O Callender "Community Education and Empowerment Key to Increased Minority Donation Rates" (1997) 29 Trans Proc 3756.

${ }^{124}$ Such as the kidney donation by a well-known Māori broadcaster to a sportsman, Jonah Lomu.
} 
inappropriate to introduce an organ collection system involving conscription or presumed consent in New Zealand. 


\section{Chapter 6}

\section{CONTENTIOUS CLASSES OF DONORS}

\section{INTRODUCTION}

Chapter four concluded that a child is a person once it is "born alive". Consequently, this thesis argues that children have property interests in their excised body parts and, if competent, they may pass their interest in their cadaver to their representative at death. In general, the parents or guardians would be first in the order of priority to be appointed representatives of child who dies while still incompetent. ${ }^{1}$

The welfare and best interests of the child are paramount when dealing with property ${ }^{2}$ and the child must be given a reasonable opportunity to express its views and those views must be taken into account. ${ }^{3}$ No person may be guardian of the property of a child, except under an order appointing a named person or a person whom the Court thinks fit as the agent of the Court.

Parents commonly make decisions about medical treatment for their children. However, decisions to harvest body parts for transplantation or research are conceptually different from treatment, as they are not usually for the therapeutic benefit of the child. Parents do not own their children and they have a fundamental obligation to protect the child's interests until it is sufficiently mature to make its own decisions. ${ }^{4}$

Since the earliest days of organ transplantation, small numbers of children and incompetent adults have been used as organ donors, although their use is "ethically complex". ${ }^{5}$ They frequently serve as bone marrow donors, because successful bone marrow grafting requires a very compatible tissue match, which may exist between siblings. From a Kantian, non-consequentialist perspective, such donations infer the use of the source as a means to the ends of others. If consent is given by parents or caregivers the child or incompetent adult may be compelled to donate, even though competent adults could not be similarly compelled. There is no general common law duty to rescue another, although Ross has suggested that there may be an ethical duty on children to undergo invasive procedures in certain circumstances, such as to save the life of a sibling. ${ }^{6}$ It has been argued that, with respect to children, a "familial" or "relationship-based" approach is more relevant than the traditional individualistic approach. Crouch and Elliott state: ${ }^{7}$

\footnotetext{
${ }^{1}$ See the discussion of representatives in chapter 8.

${ }^{2}$ Care of Children Act 2004, s 14.

${ }^{3}$ Care of Children Act 2004, s 6.

${ }^{4}$ Note that the Trustee Act 1956, ss 41 and 42 provide that trustees may make decisions about the use of property for the education, maintenance, benefit and advancement of the minor beneficiary. The Care of Children Act 2004, s 14 provides that the welfare and best interests of the child are paramount when dealing with property. No person may be guardian of the property of a child, except under an order appointing a named person or a person whom the Court thinks fit as the agent of the Court. However, nothing in the Act limits any powers of the High Court in relation to, or in relation to the administration of, any property held on trust ${ }^{5}$ Australian Health Ethics Committee of the National Health and Medical Research Council Ethical Issues in Donation of Organs or Tissues by Living Donors (Draft Discussion Paper 2) (Health and Medical Research Council, Canberra, 1996) 11.

${ }^{6}$ Lainie Friedman Ross “Moral Grounding for the Participation of Children as Organ Donors” (1993) 21 J law med ethics 251, 258.

${ }^{7}$ C Crouch and C Elliott "Moral Agency and the Family: The Case of Living Related Organ Transplantation” (1999) 8 Cambridge Quarterly of Healthcare Ethics 275, 275.
} 
When it comes to moral decisions about the family, the tools of moral philosophy and the law have not always served us well, particularly when the question involves exposing one family member to risks for the sake of another.

However, the World Health Organisation Guiding Principles on Organ Transplantation state: "No organ should be removed from the body of a living minor for the purposes of transplantation." 8 The Law Reform Commission of Canada identified three potential objections to the use of minors as organ donors:

- $\quad$ consent is a prerequisite for all bodily intrusions;

- $\quad$ a balancing of social worth is inevitably implicated in child donation; and

- donor benefit is illusory. ${ }^{9}$

Children and mentally impaired adults have widely varying cognitive abilities and the concept of incapacity is, to some extent, culture specific. A total prohibition of the use of body parts from such groups has the advantage of certainty and ensures the source's legal protection, but fails to reflect the varying levels of competence. Additionally, there are circumstances where the transplantation of a body part from a mentally incompetent person may be justified, to avoid psychological damage to that person.

This chapter will argue that a competent child may appoint a representative and give an effective consent, and although the supporting consent of parents is desirable, it should not be required. ${ }^{10}$ A flexible standard, similar to that proposed in Gillick $v$ West Norfolk and Wisbech AHA (Gillick) ${ }^{11}$ is appropriate, rather than the selection of a chronological age at which consent can be given. However, if parents oppose the child's decision, independent determination of the capacity and consent of the minor should be required. Refusal of consent by a competent minor should always be effective.

It is argued that organ harvest from a living child who is not Gillick ${ }^{12}$ competent should not take place without the consent of a court or the Human Tissue Authority. ${ }^{13}$ Concerns about the well-being of children who are the sources of body parts must outweigh the parental discretion to make the decision most likely to benefit the family unit. If excised body parts are property, then the property could only be dealt with by a person appointed by the court, acting in the best interests of the child. ${ }^{14}$

It is important to conduct research on children and mentally incompetent adults, but there must be protection of their rights and interests. This chapter will consider whether the ethical framework required by the Ministry of Health's Operational Standards for Ethics

\footnotetext{
${ }^{8}$ World Health Organisation “Guiding Principles on Human Organ Transplantation” (1991) 337 Lancet 1470 Principle 4.

${ }^{9}$ Law Reform Commission of Canada Procurement and Transfer of Human Tissues and Organs Working Paper 66 (Minister of Supply and Services, Ottawa, 1992) 48.

${ }^{10}$ This differs from the Human Tissue Bill, which provides for an approach based on age, not capacity. See the discussion in chapter 2.

${ }^{11}$ Gillick $v$ West Norfolk and Wisbech AHA [1986] AC 112 (HL) Lords Fraser, Scarman, Bridge, Templeman and Nourse. The House of Lords held that some children are legally competent to consent to some medical treatment. They can give an effective consent to medical treatment when they have attained sufficient age and understanding to weigh the risks and the benefits of the proposed treatment.

${ }^{12}$ Gillick $v$ West Norfolk and Wisbech AHA, above.

${ }^{13}$ See the discussion in chapter 8 about the jurisdiction of the Authority.

${ }^{14}$ Care of Children Act 2004, s 14.
} 
Committees is sufficient protection for incompetent participants. ${ }^{15}$ It will argue that protective mechanisms are required if the incompetent's property is being taken for a purpose that does not provide therapeutic benefit. It is extraordinary that such protections apply to other property belonging to or held in trust for an incompetent person, but not for body parts, which are substantially more significant for the person's welfare.

\section{CHILDREN}

\section{A Competence}

A competent person should be able to donate body parts and appoint a representative. However, it is difficult to define the level of understanding necessary before a person is competent to make healthcare decisions. The English Court of Appeal has expressed the test of competency for adults as: ${ }^{16}$

A person lacks capacity if some impairment or disturbance of mental functioning renders the person unable to make a decision whether to consent to or refuse treatment. That inability to make a decision will occur when:

(a) the patient is unable to comprehend and retain the information which is material to the decision, especially as to the likely consequences of having, or not having, the treatment in question;

(b) the patient is unable to use the information and weigh it in the balance as part of the process of arriving at the decision.

A person under the age of 16 years is presumed incompetent, unless the person's competence meets the test in Gillick ${ }^{17}$ or $\operatorname{Re} C{ }^{18}$ In $\operatorname{Re} R$ (a Minor) (Wardship: Medical Treatment), Lord Donaldson MR stated that Gillick ${ }^{19}$ competence requires: $^{20}$

[N]ot merely an ability to understand the nature of the proposed treatment...but a full understanding and appreciation of the consequences both of the treatment in terms of intended and possible side-effects and equally important, the anticipated consequences of a failure to treat.

Thus, a higher standard of competence is required for children than for adults. In Re $M$ (Medical Treatment: Consent), ${ }^{21}$ a 15 -year-old girl was in need of an urgent heart transplant, without which she was likely to die within one week. She refused to consent. She stated that she understood the nature of the operation, the procedure involved, and the post operative requirements, which included a lifelong requirement to take drugs. She did not wish to undergo this regime, or to survive with another person's heart. It was held that, in light of the fact that events had overtaken her so swiftly, she was unable to come to terms with her situation and was deemed incompetent to decide. This decision is apparently based on her

\footnotetext{
${ }^{15}$ Ministry of Health Operational Standards for Ethical Committees (Ministry of Health, Wellington, 2002) $<$ http://www.moh.govt.nz> (last accessed 1 March 2004).

${ }^{16}$ Re MB (Medical Treatment) [1997] 8 Med.LR 217, 224 (CA) Butler-Sloss, Saville and Ward LJJ; Re C (Adult Refusal of Medical Treatment) [1994] 1 WLR 290 (Fam D) Thorpe J.

${ }^{17}$ Gillick $v$ West Norfolk and Wisbech AHA [1986] AC 112 (HL) Lords Fraser, Scarman, Bridge, Templeman and Nourse.

${ }^{18} \operatorname{Re} C$ [1997] 2 FLR (Fam D) Munby J 180, 196.

${ }^{19}$ Gillick $v$ West Norfolk and Wisbech AHA,above.

${ }^{20}$ Re R (a Minor) (Wardship: Medical Treatment) [1992] Fam 11, 26 (CA) Donaldson MR, Staughton and Farquharson LJJ.

${ }^{21}$ Re M (Medical Treatment: Consent) [1999] 2 FLR 1097 (Fam D).
} 
status as a child, rather than her actual competence. Such an approach can only be justified if it is accepted that minors are different from others and thus deserving of protection, even from themselves. If the law accepts the concept of an autonomous minor, then the statusbased approach is inapplicable to competent minors.

In Re E (A Minor: Medical Treatment), ${ }^{22} \mathrm{E}$ was approaching 16 years of age. He suffered from leukaemia, but his religious faith precluded a necessary blood transfusion. His parents supported his refusal. The Court, while noting his intelligence and appreciation of the consequences of refusal, found that E's understanding did not satisfy the competence test. The treatment was authorised. On reaching 16, he again refused treatment and his view was accepted. He subsequently died. ${ }^{23}$ This suggests that immediately prior to his birthday he was "incompetent", and the next day he became "competent" and, consequently, was able to effectively refuse treatment. In this case, competency was not stated as the determinant factor, but just one component of determining best interests. However, the result appears to have been determined by status, rather than competence.

Thus, in English law, ethical principles other than autonomy may prevail, even if a person is competent. "Welfare" or "best interests" principles parallel the principles of beneficence and nonmaleficence. Mason and McCall Smith argue that this position is defensible and state "while consent involves acceptance of an experienced view, refusal rejects that experience- and does so from a position of limited understanding." ${ }^{24}$ Huxtable, however, states that this argument operates under cover of beneficence, but seems to stray into paternalistic intervention. ${ }^{25}$ He opines that most lay people operate from a position of limited understanding and states that accepting such an argument necessitates deference to medical professionals, ostensibly because they know what is really in the patient's best interests.

In $R e W^{26}$ Lord Donaldson MR stated that, at least theoretically, a parent could consent to living donation by a competent minor, even if the minor had declined to donate, although he considered that from an ethical perspective doctors should not proceed without the agreement of the minor. However, he held that, even if a minor was Gillick competent, it was inconceivable that a doctor should proceed with tissue harvest without the consent of both the young person and the parents. He also suggested that an application to the court should be made in the case of disagreement. Nolan LJ stated that where major surgical or other procedures are proposed and the parents consent over the child's refusal, then the jurisdiction of the court should be invoked. ${ }^{27}$

The HTB proposes that a person of or over 16 years will be presumed to be competent. ${ }^{28}$ However, those under the age of 16 , person may only consent to matters such as genetic testing but, irrespective of competence, cannot make any other decisions under the Bill. $^{29}$ The justification for this rather odd provision relates to the difficulty of assessing children's competence after they have died. No doubt it would be uncommon for children

\footnotetext{
${ }^{22}$ Re E (A Minor: Medical Treatment) [1993] 1 FLR 386 (Fam D) Stephen Brown P.

${ }^{23} \operatorname{Re~S}$ (A Minor) (Consent to Medical Treatment) [1994] 2 FLR 1065, 1075 (Fam D) Johnson J.

${ }^{24} \mathrm{~J}$ K Mason and R A McCall Smith Law and Medical Ethics (5 ed, Butterworths, London, 1999) 260.

${ }^{25}$ Richard Huxtable "Case Commentary: Time to Remove the 'Flack Jacket'? Re M (Medical Treatment: Consent)" (2000) 12 CFLQ 83.

${ }^{26} \operatorname{Re} W(1992) 3$ WLR 758, 767F (CA) Lord Donaldson MR, Batcombe and Nolan LLJ.

${ }^{27} \operatorname{Re} W$, above, 779 .

${ }^{28}$ Human Tissue Bill, clause 43.

${ }^{29}$ Human Tissue Bill, clause 37. This is justified because, in most cases, the assessment of capacity will take place after death. See chapters 2 and 8.
} 
under 16 to consent, or appoint a nominee, but those who did so would most likely have increased awareness of donation.

A report of the American Medical Association recommends that "[i]f a child is capable of making his or her own medical treatment decisions, he or she should be considered capable of deciding whether to be an organ or tissue donor." ${ }^{\text {"3 }}$ There is no simple answer as to when a young person is able to decide for themselves. In one study of 120 children undergoing paediatric orthopaedic surgery, the opinions of patients, parents and health professionals were canvassed as to the age at which children could decide about non-life saving treatment. The children set the highest threshold at 14 years, the parents at 13.9 years and health professionals chose the lowest figure of 10.3 years. ${ }^{31}$

\section{B Best Interests}

Donation of body parts is not of therapeutic benefit to the donor but there may be psychological benefit arising from the survival of a person of emotional value to the donor, such as a sibling, or from having behaved altruistically. In the United States, the Supreme Court has demonstrated in several contexts an unwillingness to intervene in the decisions of parents regarding their children. ${ }^{32}$ However, there are limits on parental authority. Rutledge J stated: ${ }^{33}$

\section{Parents may be free to become martyrs themselves. But it does not follow they are free, in identical circumstances, to make martyrs of their children before they have reached the age of full and legal discretion when they can make that choice for themselves.}

The best interests test has been applied in the United States to a number of tissue donation cases. In Hart $v$ Brown, ${ }^{34}$ both parents and two guardians ad litem agreed to the use of a seven-year-old girl as a kidney donor for her identical twin sister. The Court permitted the transplantation, as there was parental consent and a strong identification between the donor and her sister, on the grounds that the donor would be better off in a family that was happy, than in a family that was distressed. Similar reasoning was applied in Little $v$ Little, ${ }^{35}$ a case where a mentally incompetent 14 year old provided a kidney, holding that "there is strong evidence to the effect that she will receive substantial psychological benefits from such participation.”36 Best interests were interpreted to include both physical and psychological benefits.

In contrast, in the case of Curran $v$ Bosze ${ }^{37}$ the Court was asked to overrule the refusal of the mother of three-year-old twins to allow them to be tested as potential bone marrow donors for their older half brother, who was their father's child by a previous relationship. The twins had only met the prospective recipient twice and the father had left

\footnotetext{
${ }^{30}$ Council on Ethical and Judicial Affairs of the American Medical Association The Use of Minors as Organ and Tissue Donors Report 56 (American Medical Association, Chicago, 1994) 240.

${ }^{31}$ Priscilla Alderson Choosing for Children: Children's Consent to Surgery (Oxford University Press, Oxford, 1990) 9.

32 Such as Wisconsin v Yoder (1972) 406 US 205, 220 (Wisc Sup Ct); Pierce v Society of Sisters (1925) 268 US 510, 534-35 (Sup Ct).

${ }^{33}$ Prince v Massachusetts (1944) 321 U S 158, 170 (Sup Ct) (upholding a state statute prohibiting minors from selling in the streets with regard to the distribution of religious literature).

${ }^{34}$ Hart $v$ Brown (1972) 289 A 2d 386 (Ill Sup Ct).

${ }^{35}$ Little v Little (1979) 576 SW 2d 493 (Tex Civ).

${ }^{36}$ Little v Little, above, 500.

${ }^{37}$ Curran v Bosze (1990) 566 NE 2d 1319, 1326 (Ill Sup Ct).
} 
the family. The Court declined to order the testing. It held that if there was to be any benefit in the cases of donation by children, it would necessarily involve a psychological benefit. This was not a benefit from altruism in an abstract theoretical sense and it was to be grounded in the fact that the donor and the recipient are known to each other as family, as only in the case of an existing relationship could a benefit realistically be found to exist.

Gillick $^{38}$ competent persons are able to balance the relevant factors in deciding whether to donate, such as the nature of the research or treatment, the chances of success of the transplantation and the ongoing consequences that may result, both for them and the recipient. If they decide not to donate, compulsion is not in their best interests. Parents may argue that the refusal is based on factors such as a dislike of medical procedures and that, as the child matures, s/he will come to realise that the benefit of having saved a sibling outweighed the short-term discomfort, and that the parents were right to consent. However, it is unlikely that a court would order donation in the face of the child's opposition.

Alternatively, competent children may decide to donate even though the procedure is not in their medical best interests, because of psychological and emotional factors. Even if the decision is contrary to medical recommendations, it does not necessarily suggest that the young person lacked competence, or was so distressed by the illness of a family member that a reasoned decision was not possible. Adults' decisions to donate tissue or organs do not typically involve a rational weighing of costs against benefits. Therefore, it is inappropriate to require competent minor to undertake this weighing exercises. In this context, the best interests' standard may result in a lack of respect for persons, because it fails to allow minors to act altruistically. Rather, it permits decision making by minors only when it is in their best interests. $^{39}$

Several studies have indicated benefits to donors. Fellner and Marshall studied adult kidney donors and found that the psychosocial consequences of donating included increased self-esteem, growth as a person, and satisfaction gained from the recovery of the recipient, as well as identification of the process as one of the most meaningful events in the donor's life. $^{40}$ Bernstein and Simmons included a small number of adolescents in their study of kidney donors and found that the donors experienced gratitude from the recipients and from the rest of the family. These adolescents experienced personal benefits from having saved a life and experienced even greater increases in self esteem than adults. ${ }^{41}$ Freund and Siegel found a particular closeness in the relationship between many bone marrow donors and their sibling recipients. ${ }^{42}$ Robbennolt, Welsz and Lawson have suggested that the best interests' standard should be revised to include the wishes of the child and the benefits of acting altruistically. ${ }^{43}$

In contrast, researchers at the University of California found that one third of children whose siblings were bone marrow recipients suffered from signs of post traumatic stress syndrome, whether or not they were the donor, but the negative symptoms were worse in the

\footnotetext{
${ }^{38}$ Gillick $v$ West Norfolk and Wisbech AHA [1986] AC 112 (HL).

${ }^{39}$ Rachel M Dufault "Bone Marrow Donations by Children: Rethinking the Legal Framework in Light of Curran v Bosze” (1991) 24 Connecticut L Rev 211, 237.

${ }^{40}$ C H Fellner and J R Marshall “Kidney Donors: the Myth of Informed Consent” (1970) 126 American Journal of Psychiatry 1245, 1245.

${ }^{41}$ D M Bernstein and R G Simmons “The Adolescent Kidney Donor: The Right to Give” (1974) 131 Am j psychiatr 1338, 1339.

42 B L Freund and K Siegel "Problems in Transition Following Bone Marrow Transplantation: Psychosocial

Aspects” (1986) 56 Am j orthopsychiatr 244, 244.

43 Jennifer K Robbennolt, Victoria Welsz and Craig M Lawson “Advancing the Rights of Children and Adolescents to be Altruistic: Bone Marrow Donation by Minors” (1994) 9 J law health 213, 245.
} 
donor children. ${ }^{44}$ However, this could be a result of the family trauma rather than from donation per se. Cheyette states that reliance on assumptions about the lack of risk and psychological benefits of donation are misleading. ${ }^{45}$ Consequently, she argues against donation by incompetent donors. She concludes that it is inequitable to protect the competent adult's right to opt out of donation, whilst permitting caregivers to volunteer children and the mentally disabled. She questions whether the interests of the donor child are adequately protected, in light of the research findings as to the possible adverse psychological effects. Thus, best interests are a complex equation, and parents facing the imminent death of a family member may be unable to weigh the factors in a dispassionate fashion.

\section{Substituted Judgment}

The substituted judgment test requires the decision maker to make the choice that the incompetent person would have made, if competent. This test has clear advantages if the person was previously competent and their views are known. However, if the person has never been competent, the test is of limited value.

Some courts and commentators have argued that substituted judgment is not appropriate in the context of organ or tissue donation by children. The determination of what the minor would do, if competent, is thought to be too uncertain to justify the risk to the minor. ${ }^{46}$ However Robbennolt, Welsz and Lawson suggest that as, in general, people do choose to donate to siblings in order to save the sibling's life, it is reasonable to extrapolate that as evidence of what a minor under those same circumstances would choose to do, if competent. ${ }^{47}$ This argument is highly speculative, and is insufficiently convincing to justify organ donation by incompetent persons.

\section{The New Zealand Legal Position}

There is no legislation or case law directly on point and yet it appears that bone marrow transplants from and between children take place, without resort to approval by the court or independent consideration of the best interests of the donor.

\section{The New Zealand Bill of Rights Act 1990}

Section 11 of the New Zealand Bill of Rights Act 1990 provides that "everyone has the right to refuse to undergo any medical treatment." Section 3 confines the Act to acts done by the legislative, executive, or judicial branches of the Government of New Zealand, or by any person or body in the performance of any public function, power or duty, conferred or imposed on that person or body, by or pursuant to law. From this section, it could be argued that the Act does not apply to the relationship between a doctor in private practice and patient, but would apply to the relationship between a patient and hospital (although not private hospitals). In Re $J{ }^{48}$ Ellis J stated: "I accept that the Act applies to the actions of the Director-General, the police, and the doctors employed by Healthcare Hawkes Bay." He did not consider whether the rights would have a wider application. However, Austin, relying on

\footnotetext{
${ }^{44}$ Philip Cohen “Donor’s Dread: Why do Children who help a Sick Sibling End up Depressed?” (1997) 155 New Scientist 20, 20.

${ }^{45}$ Cara Cheyette "Organ Harvests from the Legally Incompetent: An Argument against Compelled Altruism (2000) 41 Boston College L Rev 465, 469.

${ }^{46}$ David S Lockemeyer “At What Cost Will the Court Impose a Duty to Preserve the Life of a Child?” (1991) Clev State L Rev 577, 586.

${ }^{47}$ Robbennolt, Welsz and Lawson, above, 230.

${ }^{48}$ Re J (an infant): Director-General of Social Welfare v B and B [1995] 3 NZLR 73, 80 (HC) Ellis J.
} 
the legal duties of doctors, contends that "[u]ntil a New Zealand case arises directly on point it needs to be assumed for present purposes that the Bill of Rights Act applies to the relationship between doctors and patients and other relationships controlled by section 25 of the Guardianship Act 1968." ${ }^{49}$ Austin further states: "Though children should be accorded the protection of section 11 because they are people,... a New Zealand court might be asked to articulate principles that would justify limiting the application of the right to children because they are children." ${ }^{50}$ Austin argues that children, even if mentally competent, should not have an unfettered right to make their own medical decisions.

International covenants

The United Nations Convention on the Rights of the Child provides in article 3:

1. In all actions concerning children, whether undertaken in public or private social welfare institutions, courts of law, administrative authorities or legislative bodies, the best interests of the child shall be a primary consideration.

2. States Parties undertake to ensure the child such protection and care as is necessary for his or her well-being, taking into account the rights and duties of his or her parents, legal guardians, or other individuals legally responsible for him or her, and, to this end, shall take all appropriate legislative and administrative measures.

Article 5 requires states to respect the responsibilities, rights and duties of parents in the child's upbringing. Article 6 recognises the child's right to life and the State's duty to ensure to the maximum extent possible the survival and development of the child.

\section{Health and Disability Commissioners Code of Health and Disability Services Consumers' Rights}

The Code recognises the right to make an informed choice and give informed consent. Right 7(2) provides: "Every consumer must be presumed competent to make an informed choice and give informed consent, unless there are reasonable grounds for believing that the consumer is not competent". Right 7(7) provides that every consumer has the right to refuse services and to withdraw consent to services. The point at which a consumer becomes competent is a matter for other enactments and the common law, as is considered later in this chapter. However, the clear thrust of the Code is that people should, wherever possible, make health-care decisions for themselves.

\section{$4 \quad$ Children of or over the age of 16 years}

Section 36 of the Care of Children Act 2004 provides that a consent, or refusal to consent, to any medical, surgical, or dental treatment or procedure, if given by a child of or over the age of 16 years, has effect as if the child were of full age. The young person can only consent to treatment "for the child's benefit". This may prevent consent to organ donation and medical experimentation, as these do not medically benefit the young person, although there are other types of benefit, such as psychological well-being. Section 36 does not state that a child under the age of 16 years cannot give an effective consent or refusal to medical procedures.

\footnotetext{
${ }^{49}$ Graeme Austin “Righting a Child's Right to Refuse Medical Treatment” (1992) 7 Otago L R 578, 581.The Guardianship Act has now been replaced by similar provisions in the Care of Children Act 2004.

${ }^{50}$ Austin, above, 581.
} 
A question arises as to whether the legal capacity to refuse consent "as though the child were of full age" would operate as a legal veto, should the parents give consent on behalf of the child. Although the New Zealand courts have not considered this point, it is likely that this would be the case, as there has been general approval of Gillick. The second issue is whether the child's consent could be overruled by the court. It is likely that they would do so, especially with regard to decisions that risk death or serious harm.

The Human Tissue Bill proposes that persons of or over 16 years may give consent for the use of body parts and may appoint a nominee to act after their death. ${ }^{51}$.Children over the age of 16 years are able to seek a review of a guardian's decision. ${ }^{52}$ The Law Commission stated that this does not recognise the received wisdom that children have rights independent of their parents, as New Zealand has recognised by ratifying the United Nations Convention on the rights of the child. That convention, in articles 5 and 14.2, recognises that a legal guardian's responsibility to provide directions to a child is subject to the child's "evolving capacity". The Law Commission unsuccessfully recommended that the age at which children can apply to the Family Court should be 12 years. ${ }^{53}$

\section{$5 \quad$ Children under the age of 16 years}

Children under the age of 16 years will, as they mature, have increased understanding and, at some stage, will be able to make an informed decision about collection and use of their body parts. This may or may not be in accord with the opinions of their parents.

Section 36 validates the consent of a guardian to procedures on children under the guardian's care. Even if the child has a right to consent, the section recognises another valid consent, which could override a child's refusal. The alternative interpretation is that section 36 validates consent by guardians only where the consent of persons other than children are "necessary", and so consent from someone other than the child would be insufficient, if the child had refused the procedure. Either way, it is highly unlikely that a court would authorise the harvest of body parts without the agreement of the parents and the assent of the child, if it is able to express preferences. Section 16(c) includes in the duties, powers, rights, and responsibilities of a guardian, the determining for or with the child, or helping the child to determine, questions about important matters affecting the child, which includes non-routine medical treatment.

The Human Tissue Bill proposes that children under 16 will be able to consent to genetic testing, but will not be able to consent to organ harvest after death or appoint a nominee to consent on their behalf. ${ }^{54}$ That decision will be made by the senior available next of kin who are listed as being firstly a parent, then a guardian, then an adult sibling. ${ }^{55}$

\footnotetext{
${ }^{51}$ Human Tissue Bill, clause 37.

${ }^{52}$ Care of Children Act 2004, s46.

${ }^{53}$ Law Commission Submissions to the Select Committee on the Care of Children Bill (Law Commission, Wellington, 2004) 18.

${ }^{54}$ Human Tissue Bill, clause 37.

${ }^{55}$ Human Tissue Bill, schedule 2, Part 2.
} 
It is unclear whether non-therapeutic medical procedures such as organ donation are in an incompetent child's best interests. ${ }^{56}$ Benefits may accrue of a non-medical nature, such as the virtues of altruism and social obligation, or having saved the life of a sibling. Whether these outweigh the harms, risks and detriments depends on how each factor is weighed.

Schoeman argues that intimate relationships transcend the traditional moral boundaries that give rigid shape to the self and instead create an environment in which mutual purpose and group identity flourish. ${ }^{57}$ The family requires considerable privacy in order to develop this intimacy, so family autonomy should only be interfered with if it can be shown that the family's actions will cause the child serious harm.

Veatch states that intimate guardians ought to be held to a subjective best interests standard, which allows them to look beyond the interests of the child concerned, to factor in the moral values, religious beliefs and social ideals of the family, as well as the larger repercussions the decision is likely to have on both the patient and the family. ${ }^{58}$

Lanie Friedman Ross argues that: ${ }^{59}$

Viewed from the perspective of family autonomy, the decision to allow one child to donate an organ to a sibling can be morally permissible provided that there is an ongoing intimate (bonded) relationship between the authorizing parents and the child-donor.

However, she would prescribe limits on family autonomy, in that parents can only permit their child to participate as an organ donor if they are not eliminating the child's capacity to act autonomously and provided that they are promoting the child's capacity to flourish in other ways. ${ }^{60}$ She asserts that the State should prohibit parents' consent to child donation if it finds the donation incompatible with respecting the child's personhood.

In $R e G W W$ and $C M W,{ }^{61}$ an application was made for an order authorising a bone marrow harvest from a ten-year-old child for donation to his aunt. The child had an understanding of the proposed procedure and did not oppose it, but was not Gillick competent. The Court decided that the psychological benefit to the child outweighed the minimal risks and consequences of the procedure and therefore it was in his best interests. The child was the only fully matched related donor, although a number of potential unrelated donors were identified on the Australian Bone Marrow Donor Registry. The aunt's chance of a cure with an unrelated donor was 20-30 per cent, while the chance of survival with the child as the donor was 25-40 per cent.

Hannon J held that it was a special case that required judicial approval, because the operation was for the benefit of the third party and, in considering whether to make an order

\footnotetext{
${ }^{56} \mathrm{~A}$ child has a right to expect that guardians will carry out their duties and responsibilities for the child's benefit and welfare. $N v D$ [guardianship] (1993) 11 FRNZ 303, also reported as Neho $v$ Duncan [1994] NZFLR 157, 160; Nixon v Nixon 10/10/02, Judge Inglis QC, FC Manukau FP048/694/95, para 8.

${ }^{57}$ Ferninand Schoeman "Rights of Children, Rights of Parents, and the Moral Basis of the Family" (1980) 91 Ethics 8, 8.

${ }^{58}$ Robert M Veatch “Limits of Guardian Treatment Refusal: A Reasonableness Standard” (1984) 9 Am J L \& Med 427, 431.

${ }^{59}$ Lainie Friedman Ross "Moral Grounding for the Participation of Children as Organ Donors” (2001) 21 J L Med \& Ethics 251, 252.

${ }^{60}$ Ross, above, 253.

${ }^{61}$ Re GWW and CMW (1997) FLC $992-748$ (FCA) Hannon J.
} 
relating to the welfare of the child, the court must regard the best interests of the child as the paramount consideration. ${ }^{62}$ It must consider any wishes expressed by the child and any factors (such as the child's maturity or level of understanding) that the court thinks are relevant to the child's wishes. ${ }^{63}$

A further relevant factor is whether there is a sufficiently close relationship between the child and the recipient, which is of benefit to the child. In such a case, it is in the best interests of the child that the relationship continues and this may be more significant than the risk or discomfort of a surgical procedure. The Court permitted the donation even though there were potentially suitable adult donors available.

In many areas of family life, parents set the interests of one child against those of other children, or the family unit. It is generally in a child's best interests to live in a family that is allowed flexibility when balancing the interests of family members. This would imply that the parents should be free to decide whether a child might donate to a sibling. However, protective mechanisms for children are needed. This thesis argues that the decision to consent to organ or tissue harvest from an incompetent child should always be made by a court or the Human Tissue Authority, because of the risk of parental conflicts of interests, especially when the recipient is a sibling, or other relative of the donor child.

\section{E Guidelines}

Price argues that a Gillick competent child should be able to decide whether to behave in an altruistic manner. ${ }^{64}$ He suggests a totally flexible standard, based on a determination of competence or, alternatively, that such a flexible standard should apply once a threshold age has been attained, such as 14 years.

This thesis supports Price's suggestions, and suggests the Human Tissue Authority should determine whether guidelines are necessary to protect the interests of the child, recipient and family. ${ }^{65}$ Among the matters that could be included are:

- Incompetent donors should only be used if there is no suitable competent donor available;

- There must be a high likelihood of significant improvement in the recipient's condition;

- The donor and the recipient must have a close emotional relationship, which may arise without actual family relationship. However, it would exclude donation by children who do not live with or have close contact with, the recipient, or donation to distant relatives;

- $\quad$ The child who is sufficiently mature to formulate preferences must be willing to participate. A minor should not be permitted to undergo an unreasonably dangerous donation and, in light of the potential for family pressure, the child should be independently assessed and counselled;

- In general, only regenerative tissue should be removed from children. Although liver donation involves regenerative tissue, the risks of donation are such that it should not be permitted;

\footnotetext{
${ }^{62}$ Family Law Act 1975 (Australia), s 67ZC(2).

${ }^{63}$ Family Law Act 1975 (Australia), s 68F(2)(a).

${ }^{64}$ David Price Legal and Ethical Aspects of Organ Transplantation (Cambridge University Press, Cambridge, 2000) 345.

${ }^{65}$ The guidelines would be constructed by the Human Tissue Authority after a process of public engagement. See the discussion in chapter 8.
} 
- $\quad$ There should be a presumption against repeated donations;

- $\quad$ Decisions to donate should not be made by parents, whose judgment may be affected by the exigencies of the situation. A court or the Authority, acting within the guidelines, should decide. ${ }^{66}$

Although such decisions are usually made within the family, it cannot be said that families are necessarily protective or safe places for children. It is proposed that, if a child is Gillick competent, then the child must consent to any donation and the parents should not be able to overrule any refusal. If the parents believe the competent child's consent is not in the best interests of that child, they should be able to apply to the Authority, which could overrule or confirm the decision. ${ }^{67}$

A competent child should be able to make decisions to apply after death, and appoint a representative to carry out these instructions. ${ }^{68}$ It is likely that even if Gillick competent, many young people would not appoint a representative, in which case, the parents would be first in the priority list of representatives. ${ }^{69}$ Children who are not Gillick competent should have the protection of independent decision making in all cases. The expressed or apparent reluctance to proceed of a child should always be respected.

Whilst a property construct is not essential to ensure such protections, the notion of a property interest which can be passed to a representative is not incompatible with the interests of children and this is a means to ensure that the wishes of competent children are followed.

\section{ORGAN DONATION BY MENTALLY INCAPACITATED PERSONS}

\section{Protection of Personal and Property Rights Act 1988}

A welfare guardian appointed under the Protection of Personal and Property Rights Act 1988 does not have the power to: ${ }^{70}$

- $\quad$ refuse consent to standard medical treatment, or procedures intended to save the person's life, or to prevent serious damage to the person's health; ${ }^{.1}$ or

- consent to medical experimentation other than for the purpose of saving the person's life or preventing serious damage to the person's health. ${ }^{72}$

As organ or tissue donations are not standard treatments, the Court must make orders under section 10(1)(f) or section 18(2) for harvest to take place. The treatment must be necessary in the interests of the disabled person, and the court must make the least restrictive intervention possible, so it is unlikely that it would authorise a welfare guardian to consent to organ donation on behalf of an incompetent adult. Thus, adults have greater protection than incompetent children.

If excised body parts are the incompetent source's property, then they would have the additional protection provided by the property rights part of the Act. ${ }^{73}$ This provides for the

\footnotetext{
${ }^{66}$ See the discussion in chapter 8.

${ }^{67}$ Alternatively, the role could be within the jurisdiction of the Family Court.

${ }^{68}$ See the discussion in chapter 8.

${ }^{69}$ See the priority list in chapter 8 .

${ }^{70}$ Protection of Personal and Property Rights Act 1988, s 19(1)(a-f).

${ }^{71}$ Protection of Personal and Property Rights Act 1988, s 18 (1)(c).

${ }^{72}$ Protection of Personal and Property Rights Act 1988, s 18 (1)(f).

${ }^{73}$ Protection of Personal and Property Rights Act 1988, Part 3.
} 
making of a property order under section 11 or the appointment by the court of a manager ${ }^{74}$ to exercise the powers specified in the appointment. Thus, the manager could administer the retention and use of body parts, both to ensure that any benefits are preserved for the source ${ }^{75}$ and to ensure that the person's wishes and cultural views are respected, as far as possible. Section 54 provides that the existence of such an order does not necessarily mean that the person lacks testamentary capacity. The issue of whether the person was able to appoint a representative to take the property interest in the body parts after death would fall within this section.

The Act emphasises the promotion and protection of the welfare and best interests of the incompetent person, while seeking to encourage the person to develop and exercise such capacity as that person has to understand the nature and foresee the consequences of decisions relating to personal care and welfare, and to communicate such decisions. ${ }^{76}$

\section{Best interests}

In England, decisions on medical treatment for incompetent adults are made using the best interests test, as set out in Re F (Mental Patient: Sterilisation), ${ }^{77}$ which encompasses the protection of the incompetent patient's contemporaneous welfare. This requires the weighing of the benefit and detriment that might flow from the procedure. The English Law Commission has stated that organ donation "will only rarely, if ever, be in the best interests of a person without capacity, since the procedures and their aftermath often carry considerable risk for the donor." 78

However, considerations have moved beyond medical best interests, to include psychological and social interests. In Re Y (Mental Incapacity: Bone Marrow Transplant), ${ }^{79}$ Connell $\mathrm{J}$ authorised blood tests and bone marrow harvesting from a mentally incompetent woman for transplantation to her sister, based on the best interests of the donor. Y had been severely intellectually disabled since birth. She was 35 years old and had lived in a "community home" since she was 17 years old. Her sister was aged 36 and had a bone marrow disorder for which she had received chemotherapy. Her condition was likely to progress to acute myeloid leukaemia within three months. A bone marrow donation from a blood relative held a 40 per cent chance of recovery for 18 months, whereas a donation from an unrelated donor had, at best, a 30 per cent chance. There were two potential unrelated donors in the United Kingdom. The sister successfully applied for a declaration under the High Court's inherent jurisdiction that two preliminary blood tests and a bone marrow removal under general anaesthetic could lawfully be taken from Y.

Connell $\mathrm{J}$ found that the donation was in Y's best interests, because the applicant's prognosis without the transplant was poor, and if she were to die this would adversely affect the health of Y's mother, so her ability to visit Y would be restricted. Consequently, Y would be harmed by the reduction of contact with her mother. Despite the fact that Y apparently did not know that this regular visitor was her mother, he held that the procedures were to Y's

\footnotetext{
${ }^{74}$ Protection of Personal and Property Rights Act 1988, s 31.

${ }^{75}$ See chapter 7 for discussion of benefit sharing in the case of a patent application.

${ }^{76}$ Protection of Personal and Property Rights Act 1988, s 18.

${ }^{77}$ Re F (Mental Patient: Sterilisation) [1990] 2 AC 1, 77(HL) Goff LJ.

${ }^{78}$ Law Commission for England and Wales Mentally Incapacitated Adults and Decision-Making: Medical

Treatment and Research, Consultation Paper No 129 (Law Commission, London, 1993) 6.5

$<$ http://www.lawcom.gov.uk> (last accessed 14 February 2005).

${ }^{79}$ Re Y (Mental Incapacity: Bone Marrow Transplant) [1996] 2 FLR 787; [1997] 2 WLR 556 (Fam D) Connell $\mathrm{J}$.
} 
emotional, psychological, and social benefit. Connell $\mathrm{J}$ held that the procedure would improve Y's relationship with her mother, who wanted it to take place and would be eternally grateful to $\mathrm{Y}$.

The assessment of best interests in this case was largely based on the importance of Y's relationship with her mother and, as the mother was in poor health, anything that might exacerbate this and inhibit her frequent visits was considered to be contrary to Y's best interests.

There are two concerns about this decision. Firstly, Y's relationship, however tenuous, was with her mother, not the prospective recipient of the bone marrow. The Judge, somewhat speculatively, referred to the possibility that the donor's relationship with both her mother and sister would be likely to improve if the bone marrow transplant went ahead.

Secondly, there were possible competent donors, although the chances of success might be lower with an unrelated donor. The Convention for the Protection of Human Rights and Dignity of Human Beings with regard to the Application of Biology and Medicine prohibits the removal of regenerative tissue from incompetent persons, unless there is no compatible donor available who has the capacity to consent. ${ }^{80}$ In this case, the procedure was not necessarily in the best interests of Y.

\section{$2 \quad$ Substituted judgment}

Substituted judgment is widely used by courts in the United States in decisions about life-sustaining treatment, and in the context of organ donation and research participation by incompetent persons. ${ }^{81}$ This test requires the decision to be that which the incompetent person would have made, if competent. In Strunk $v$ Strunk, ${ }^{82}$ an application was made to approve the donation of a kidney from a mentally incompetent adult to his brother. The Court held that the transplant was in the best interests of the ward, who was emotionally and psychologically dependent upon his brother, finding that his well-being would be jeopardised more severely by the loss of his brother than by removal of a kidney. It held that renal transplants involve minimal danger to both the donor and donee and the doctrine of substituted judgment was broad enough to cover all matters touching on the well-being of the ward. Although the court discussed the substituted judgment doctrine in some detail, the conclusion was based on the benefits that the incompetent donor would derive.

Substituted judgment was rejected in a case relating to a proposed kidney donation by an incompetent catatonic schizophrenic to his sister. ${ }^{83}$ However the dissenting judge, Day J, felt that the donor, if competent, would most likely consent, because of the normal ties of family. He felt that the best interests test is a selfish test, as it precluded altruistic actions by an incompetent person. Rather than focus on evidence of the previously expressed views of this particular incompetent person (which did not exist as he had never been competent) the judge focussed on a particular view of family relationships, by inferring that if this person had ever been competent he would have been likely to consent, because decent people, in general, would do so. This is an unwarranted assumption to make, in light of the widely

\footnotetext{
${ }^{80}$ Council of Europe Convention for the Protection of Human Rights and Dignity of the Human Being with Regard to the Application of Biology and Medicine: Convention on Human Rights and Biomedicine (4 April 1997) CETS No 164, Art 20(2)(ii) DIR/JUR (96) 14.

${ }^{81} \mathrm{D}$ Wendler "Informed Consent, Exploitation and Whether it is Possible to Conduct Research Without Either One” (2000) 14 Bioethics 310, 316.

${ }^{82}$ Strunk v Strunk (1969) 445 SW 2d 145, 148-9(Ky Ct App).

${ }^{83}$ In re Guardianship of Pescinski (1975) 67 Wis 2d 4 (Wisc Sup Ct).
} 
varying levels of intimate relationships within families. Additionally, it is doubtful whether an incompetent person would have the capacity to appreciate the notion of altruism.

Public policy

In light of the difficulty of ethical justification of organ donation by the mentally incompetent, an alternative approach may be to justify it as a matter of public policy. If such a procedure is perceived as a good, it should be encouraged and enabled. This would require the conclusion that, as the procedure is a societal good, it should be lawful, even if it is not in the best interests of the incompetent person and there is no evidence of substituted judgment, such as an advance directive. A threshold of permissible harm could be established, together with a requirement of lack of dissent by the incompetent person. ${ }^{84}$

The Law Commission of England and Wales has proposed a similar approach with regard to procedures such as genetic screening. ${ }^{85}$ It proposed that the Secretary of State be empowered to allow certain procedures so long as the procedure does not cause significant harm to the person and would be of significant benefit to others. Any objection by the incompetent person would disallow the procedure. The Law Commission also recommended that non-therapeutic research on incompetent persons be lawful, if the research relates to a condition suffered by the research subject and the research does not expose the subject to more than a negligible risk. ${ }^{86}$

If incompetent people were required to act for the public good against their individual best interests, or at least not for their personal benefit, the same compulsion to donate should apply to competent persons as well. Such a suggestion is contrary to the western emphasis on individualism and autonomy and unlikely to be adopted. The property construct does not necessarily preclude compulsion as, in other contexts; property can be compulsorily acquired if the state has a pressing public policy interest in it. However, there seems no justification for only applying compulsion solely to incompetent persons.

\section{$4 \quad$ Advance directives}

Advance directives are decisions made, while competent; regarding treatment and care should the person become incompetent. Such a directive could direct the facilitation of organ donation. For example, instead of specifying that in certain circumstances (such as becoming brain dead) life support is to be withdrawn, the advance directive might request that the person be maintained on life support until the organs and transplantable tissues can be harvested. The Code specifically recognises the use of advance directives, or in the absence of such a directive, the need to take the decision that the person would have taken, based on evidence of the person's previous wishes, preferences and values. ${ }^{87}$

No case involving the advance authorisation of medical treatment that is contrary to the medical interests of the incompetent person has come before the courts in New Zealand or England. However, as a competent adult can consent to such procedures, there seems little

\footnotetext{
${ }^{84}$ Penney Lewis “Procedures That Are Against the Medical Interests of Incompetent Adults” (2002) 22 Oxf j leg stud 575, 575.

${ }^{85}$ Law Commission for England and Wales Mentally Incapacitated Adults and Decision-Making: Medical Treatment and Research (Consultation Paper no 129, Law Commission, London, 1993) 6.26

<http://www.lawcom.gov.uk> (last accessed 14 February 2005).

${ }^{86}$ Law Commission, above, 6.34 .

${ }^{87}$ Health and Disability Commissioner's Code of Health and Disability Services Consumers’ Rights, Right 7(4) and (5).
} 
reason why such consent could not be given by way of a valid advance directive. The directive must be given by a competent person, who was fully informed and acted voluntarily. It must be clearly expressed and intended to apply in the circumstances arising.

Lewis suggests two problems arising from such advance directives. ${ }^{88}$ The first is that some incompetent persons will have lost their personal identity, to the extent that they cannot be said to be the same person as the person who made the advance directive. ${ }^{89}$ The second is the conflict between a competent person's exercise of autonomy and that person's later welfare as an incompetent individual.

People should be able to make effective advance directives, as a reflection of their autonomy interests, but it is unlikely that such advance directives will become the panacea for the shortage of transplantable organs because, even when the purpose is to limit future treatment, advance directives are not made by large numbers of people. ${ }^{90}$

\title{
IV INCOMPETENT PERSONS AND RESEARCH
}

Research upon human subjects has led to substantial health benefits and the development of new treatments is largely dependent on the use of human subjects to determine their safety and effectiveness. ${ }^{91}$ Medical research on humans has been divided into two categories:

- Therapeutic research where new, or alternate, techniques are employed to determine the most effective treatment for a condition; and

- $\quad$ Non-therapeutic research, intended to advance medical knowledge rather than provide any medical benefit to the research subject.

This distinction has been criticised ${ }^{92}$ and is no longer included in the latest version of the Declaration of Helsinki. ${ }^{93}$ However, there are some types of research in which there is clearly no medical benefit for the research subject.

The Explanatory Report to the European Convention on Human Rights and Biomedicine states: ${ }^{94}$

\begin{abstract}
Were [non-therapeutic research on incompetent persons] to be banned altogether, progress in the battles to maintain and improve health and to combat diseases only afflicting children, mentally disabled persons or persons suffering from senile dementia would become impossible. The group of people concerned may in the end benefit from this kind of research.
\end{abstract}

It requires the research to be potentially beneficial to the health of the person concerned. The benefit must be real, follow from the potential results of the research and the risk must not be disproportionate to the potential benefit. Also, there must be no possible alternative subject

\footnotetext{
${ }^{88}$ Lewis, above, 575.

${ }^{89}$ See chapter 4 for a discussion of personhood.

${ }^{90}$ K Stern “Advance Directives” (1994) 2 Med L Rev 57, 75.

${ }^{91}$ Kathleen Liddell and others "Medical Research Involving Incapacitated Adults: Implications of the EU Clinical Trials Directive 2001/20/EC” (2006) 14 Med L Rev 367, 370—372.

${ }^{92}$ R Gillon "Medical Treatment, Research and Informed Consent” (1989) 15 JME 3, 4.

${ }^{93}$ World Medical Association Declaration of Helsinki: Recommendations Guiding Physicians in Biomedical

Research Involving human Subjects Adopted by the $18^{\text {th }}$ World Medical Assembly, Helsinki, June 1964 and amended in 1975, 1983, 1989, 1996, and 2000.

${ }^{94}$ Council of Europe Explanatory Report to the European Convention on Human Rights and Biomedicine (1997) para 107 < http://conventions.coe.int/treaty/en/Reports/Htm> (last accessed 3 February 2004).
} 
with full capacity. It is not sufficient that there should be no capable volunteers, as research on incompetent persons must be the sole possibility. The Report suggests as examples of research only able to be carried out on the groups concerned, research aimed at improving the understanding of development in children, such as infant diseases, or improving the understanding of diseases effecting incompetent people, such as dementia in adults.

It suggests that such research must not be carried out if the subject objects. In the case of infants or very young children, it is necessary to evaluate their attitude, taking account of their age and maturity. As well as the general conditions for research on persons not able to consent, the Report requires that a certain number of supplementary conditions must be fulfilled: ${ }^{95}$

- there is neither an alternative method of comparable effectiveness to research on humans, nor research of comparable effectiveness on individuals capable of giving informed consent;

- the research has the aim of contributing to the ultimate attainment of results capable of conferring a benefit to the person concerned, or to other persons in the same age category, or afflicted with the same disease or disorder, or having the same condition, through significant improvements in the scientific understanding of the individual's conditions, disease or disorder;

- the research entails only minimal risk and minimal burden for the individual concerned;

- the research project not only has scientific merit but is also ethically and legally acceptable and has been given prior approval by competent bodies;

- the person's representative or an authority or a person or body provided for by law has given authorisation;

- the person concerned does not object (the wish of the person concerned prevails and is always decisive);

- $\quad$ authorisation for this research may be withdrawn at any time throughout the research project.

Thus, the Convention balances the need for incompetent people to enjoy the benefits of science with the individual protection of the research subject. Similarly, the UNESCO Universal Draft Declaration on Bioethics and Human Rights provides for special protection to be given to persons who do not have the ability to consent. ${ }^{96}$

\section{A Children as Research Subjects}

Despite the benefits from research conducted on human subjects, there have been many examples of abuses, such as the inhumane experiments carried out on non-consenting prisoners by the Nazis during World War II, which led to the Nuremberg Code containing strict guidelines for the conduct of medical research.

Children have been particularly subjected to abuses by researchers. ${ }^{97}$ They are vulnerable, because they may not be competent to consent to their participation and the person giving proxy consent may have motives that go beyond the best interests of the child, especially if illness of another family member is involved. The parents may be offered incentives for involvement, which may be disguised as reimbursement of expenses and the

\footnotetext{
${ }^{95}$ Council of Europe, above, para 108.

${ }^{96}$ UNESCO Universal Draft Declaration on Bioethics and Human Rights 24 June 2005, Article 7.

${ }^{97}$ Leonard H Glantz “Research with Children” (1998) 24 Am j law med 213, 215.
} 
researcher may have motives other than, or even in conflict with, the welfare of the child. The legal authority of parents to volunteer the child for non-therapeutic research is unclear. ${ }^{98}$

However, to exclude children from participating in health research has lead to children being excluded from the benefits of that research. ${ }^{99}$ Peart notes that 81 per cent of the drugs listed in the 1991 Physicians’ Desk Reference included a disclaimer for use with children, or lacked dosage information, because the studies required, in order to ascertain the necessary information, had not been carried out. ${ }^{100}$

In the United States, the National Commission for the Protection of Human Subjects of Biomedical and Behavioral Research (the Commission) considered whether it is morally justifiable for children to be research subjects. The Commission favoured restricted participation on utilitarian grounds. Jonas expressed the argument as: ${ }^{101}$

Progress is by our choosing an acknowledged interest of society, in which we have a stake in various degrees; science is a necessary instrument of progress; research is a necessary instrument of science; and in medical science experimentation on human subjects is a necessary instrument of research: Therefore, human experimentation has come to be a societal interest.

This societal interest necessarily includes research into mental illness and the illnesses afflicting children, and those groups' participation in research into such conditions is necessary to progress towards cures, treatments and disease prevention. The use of the body materials of the Canavan children to research the genetic component of the condition was unlikely to benefit the children concerned, but did hold the hope of producing a predictive test to prevent further children being born with the condition. ${ }^{102}$ The parents stood to gain, as did potential future children, but the existing children did not.

The Maryland Court of Appeals considered two separate negligence actions involving children who allegedly developed elevated levels of lead dust in their blood, while participating in a research study. ${ }^{103}$ The Court held that researchers cannot avoid liability by relying on consents, or by institutional review board approval, especially when incomplete information is given to the party consenting. The duty to a vulnerable research subject is independent of consent, particularly with research on children, although consent must be obtained. Such legal duties arise because of the likely conflict of interests between the goals of the researchers and the health of the human subjects, especially when such research is commercialised.

The Court stated that the best interests of the child is the overriding concern and it is not in the best interest of a specific child in a non-therapeutic research project, to be placed in a research environment that might possibly be hazardous to the child's health. Despite the interests in fostering research for the good of all children, the court's concern for the

\footnotetext{
${ }^{98}$ The Care of Children Act 2004 does not refer to medical procedures for research purposes and the Code in Right 7.4 provides that if a child is not competent, any treatment must be in the best interests of the child and the person administering the treatment must take reasonable steps to ascertain the child's views but can take into account the views of other suitable persons interested in the child's welfare.

${ }^{99}$ Nicola Peart "Health Research with Children: The New Zealand Experience” (2000) 3 Current Legal Issues 421, 425.

100 Peart, above, 425.

${ }^{101}$ H Jonas “Philosophical Reflections on Experimenting with Human Subjects” (1969) 98 Daedelus $219,230$.

${ }^{102}$ Referred to in chapter 3.

${ }^{103}$ Ericka Grimes v Kennedy Krieger Institute Inc, Myron Higgins a minor etc et al v Kennedy Krieger Institute Inc (2001) 366 Md 29; 782 A 2d 807 (Ct App Maryland).
} 
particular child over-arches all other interests. It held that it is not in the best interest of any healthy child to be intentionally put in a non-therapeutic situation where his or her health may be impaired, in order to test methods that may ultimately benefit all children.

Consequently, a parent or guardian may not consent to have a child submit to painful or potentially life-threatening research procedures, with no prospect of benefit for the child. The court did not limit a parent or legal guardian's right to consent to a child's participation in therapeutic research that may be the functional equivalent of treatment. The no-risk standard led the defendants to ask the Court to reconsider its decision, arguing that the strict standard would prohibit important research. The motion was denied.

The difficulty that arises from this decision is how to determine the permissible "minimal harm". A report by the National Bioethics Advisory Commission recommended that "minimal risk should be defined as the probability and magnitude of harms that are normally encountered in the daily lives of the general population." ${ }^{104}$ However, this is not particularly helpful, as it was difficult to determine the risk of lead paint exposure in the daily lives of the general population.

In New Zealand, the Operational Standard for Ethics Committees (the Standard) ${ }^{105}$ outlines the minimum requirements to be met by ethics committees. With respect to research involving children, it states: ${ }^{106}$

The special vulnerability of children makes consideration of involving them as research participants particularly important. To safeguard their interests and to protect them from harm, special ethical considerations should be in place for reviewing research with children.

The Standard states that such research should not be undertaken unless it is ensured that:

- Children will not be involved in research that might equally be carried out with adults;

- The purpose of the research is to obtain knowledge relevant to the health needs of children;

- $\quad$ Older children are used in preference to younger;

- $\quad$ The researchers are experienced in working with children;

- The number of children involved is no more than that which is scientifically and clinically essential.

If the research is intended to provide direct therapeutic benefit to the child, then the risk must be justified by the anticipated benefit, and any relation of the anticipated benefit to the risk must be likely to be at least as favourable to the child as any available alternative. If the research is not intended to benefit the child participant, but is likely to yield generalisable knowledge about the child's disorder of vital importance to understand or ameliorate the condition, then it may be undertaken if any risk represents a minor increase over minimal risk. The research must present experiences to the child participants that are reasonably

\footnotetext{
${ }^{104}$ National Bioethics Advisory Commission Ethical and Policy Issues in Research Involving Human Participants Volume 1 (National Bioethics Advisory Commission, Virginia, 2001) <http://www.ntis.gov> (last accessed 1 March 2004).

${ }^{105}$ Ministry of Health Operational Standards for Ethical Committees (Ministry of Health, Wellington, 2002) $<$ http://www.moh.govt.nz> (last accessed 1 March 2004).

${ }^{106}$ Ministry of Health, above, 57.
} 
commensurate with those inherent in their actual or expected medical, psychological, social or educational situations. Any other research involving children may only be undertaken if the risk is minimal and commensurate with the importance of the knowledge gained.

In many cases, children will be unable to assess whether research participation will be distressing until they have experienced it. Consequently, a requirement that children make prospective decisions as to whether they wish to participate as research subjects does not effectively protect them, especially as they might not wish to disappoint the researchers or their parents, should they wish to withdraw. Children may find research protocols difficult to understand and may not benefit from the experience of being required to make decisions in such circumstances, especially if their parents are supportive of participation.

With young children, any distress evoked by the research may well be non-verbal and subject to various interpretations. All reasonable steps should be required to be taken to alleviate observed distress, and if the distress cannot be eliminated, indications of any more than minimal distress should be respected, even if the result is the removal of the child from the research. The requirement that researchers be experienced in working with children should increase the likelihood of their being able to recognise an unacceptable level of distress.

The Standard requires the data obtained from the research on children to be retained for 10 years, unless the child, on reaching the age of 16, withdraws consent to the continued use or retention of personally identifiable health research data. Thus, the issue of ownership and control of samples and information may arise once the child is competent. ${ }^{107}$ The Standard does not specifically address the retention or further use of body materials or samples, as distinct from the information ascertained from them, although the participants do have the right to withdraw from the research at any time. Children may have an interest in participating in the economic benefits from research on their body parts and, as with adults, contractual arrangements may be appropriate to ensure this. Any financial benefits should be retained in statutory trusts until the child attains majority. ${ }^{108}$

\section{B Incompetent Adults as research subjects}

Incompetent adults have the same rights as anyone else to choose whether their body parts will be utilised in research and to be protected from undue risks arising from participation. Similarly, they should be entitled to participate in profits arising from patenting of inventions based on their property. ${ }^{109}$ However, difficulties may arise in obtaining informed consent as they may have varying levels of mental impairment, or may lack the ability to express their preferences. The Standard appropriately focuses on the continuum of capacity levels, and the need to involve such persons in decisions affecting them to the fullest extent possible. ${ }^{110}$

As well as the positive utility to be gained from such research, a net gain in utility is required. Thus, the research must be scientifically sound and of sufficient scientific importance to justify the risk and burden imposed on the research subjects.

\footnotetext{
${ }^{107}$ Ministry of Health, above, 60; See Ministry of Health Guidelines on the Use of Human Tissue for Future Unspecified Research Purposes: Discussion document (Ministry of Health, Wellington, 2006) discussed in chapters 3 and 8.

108 See the discussions in chapters 3 and 7.

${ }^{109}$ See the discussion in chapter 7.

${ }^{110}$ Ministry of Health, above, 62-65.
} 


\section{CONCLUSIONS}

This thesis proposes that incompetent persons have property interests in their excised body parts. Consequently, existing legislative property protection regimes will apply. Parents or caregivers have surrogate decision-making authority in some circumstances, but this does not extend to acquisition of property in the incompetent person or the excised parts. Thus, they have a duty to preserve the property interest, rather than being able to consent to actions that would cause another to obtain the benefit of the body part. Harvest should only proceed if a court or the Human Tissue Authority decides it is in the best interests of the incompetent person. In general, competent children should have the same decision-making powers as adults, with the court or authority having the power to intervene in limited circumstances, if the decision is not in the best interests of the young person.

This approach focuses on the interests and welfare of incompetent persons, rather than on the family unit as a whole, to ensure that such sources are not subjected to greater risks of exploitation and utilitarianism than competent persons. They should be given as much information about the proposed procedure as they are able to understand and, if they indicate opposition, proxy consent should not prevail.

Children may find it difficult to refuse to donate in highly charged emotional situations, so they should be separately counselled by persons experienced in interpreting the reactions of children. It is important to divorce this decision-making from the emotions of those closely involved with the family concerned and concentrate on a detached medical and psychological evaluation. ${ }^{111}$ This is not to assume that children will necessarily accept the decisions of the court or authority as to their best interests. However, to be divorced from the decision-making process may help the parents to maintain familial relationships that will best enable them to support all their children through the ensuing processes.

This chapter argued that protection of incompetent persons' property interest in their excised body parts should fall within the legislative provisions of the Care of Children Act 2004 and the Protection of Personal and Property Rights Act 1988. However, as the property interest does not arise until excision or death, additional protection is necessary, if organs are proposed to be harvested from incompetent persons, or such persons are proposed to be the subjects of non-therapeutic research. The guidelines for such decisions would be made by the Human Tissue Authority and the decision made by an independent agency, rather than the source's family. Any advance directive made prior to incompetence would be respected. $^{112}$

The proposed framework would provide for a priority list of representatives to deal with the body after death, ${ }^{113}$ which would apply if the incompetent person had never been able to appoint a representative. The representative would be required to decide on the basis of any expressed preference by the source prior to incompetence, or if none was expressed, based on the representative's own preference.

\footnotetext{
${ }^{111}$ R Dressler "Feeding the Hunger Artists: Legal issues in Treating Anorexia Nervosa” (1984) Wisconsin L Rev 297, 328-339.

112 Alasdair R Maclean “Advance Directives, Future Selves and Decision-Making” (2006) 14 Med L Rev 292, 303-304.

113 See chapter 8.
} 


\section{Chapter 7}

\section{PATENTING OF BIOTECHNOLOGICAL INVENTIONS}

How does it feel to be patented? To learn all of a sudden, I was just a piece of material?....There was a sense of betrayal.... They owned a part of me that could never be recovered. ${ }^{1}$

\section{INTRODUCTION}

Concerns about commercialisation are the basis of most objections to a property interests in human body parts. As has been argued, ${ }^{2}$ sources have many of the "sticks" of the bundle of rights that comprise a property interest, but the sale of organs and tissue by the source is likely to be politically unattractive, and thus, unlikely to form part of public policy.

An additional concern is that property rights would allow the source to claim an interest in patented inventions arising from research utilising their body parts. Although biotechnology promises great benefits to humanity, the industry is profit orientated, spending upwards of US\$100 million annually to secure profits through the use of intellectual property law, ${ }^{3}$ leading to a danger that safety and respect for the sources of the tissue will not be paramount considerations.

Once replenishing tissue is no longer able to carry out its prescribed function, it is biologically valueless to the host organism and diseased tissue, such as Moore's spleen, may have to be removed. However, this does not mean that such tissue has no monetary value once it has fulfilled its biological function, as discovery of new uses for that which was once considered waste may confer commercial meaning to it. In light of this inherent value of body tissue, it is unfair to assert that the commercial biotechnology industry should be provided with its raw materials at no cost.

Additionally, tissue contains genetic information, which is potentially of ongoing value to the source and its unconsented publication may be objectionable. Traditional medicine has traditionally treated patients in a remedial manner, whereas genetic technologies have potential effects on succeeding generations and may alter future persons, through germ-line therapies. Additionally, they may result in genetic enhancement and the creation of new beings, such as animals containing human genes and vice versa. This potential causes public disquiet and raises concerns about the control of genetic technology.

Many countries grant patents on genes. The United States is dominant in this practice, but Commonwealth countries, such as Canada and Australia as well as most

\footnotetext{
${ }^{1}$ B Burrows "The Thoughts of a Patented Man” (1996) Earth Island Journal 27, 27: Reported comments of John Moore.

${ }^{2}$ See the discussion in chapter 1 .

${ }^{3}$ C Roberts "The Prospects of Success of the National Institute of Health's Human Genome Application” (1994) 1 EIPR 30, 30.
} 
Pacific Rim, African and Asian countries also grant such patents. ${ }^{4}$ They are also permissible in European countries that follow EC Biotechnology Directive No 98/44/EC. Article 5(2) provides:

An element isolated from the human body or otherwise produced by means of a technical process, including the sequence or partial sequence of a gene, may constitute a patentable invention, even if the structure of that element is identical to that of a natural element.

The idea of patenting genes and gene sequences seems counter-intuitive to many people, in part because genes are living material. ${ }^{5}$ This point was demonstrated in 2000, when application GB 0000180.1 was filed in the British Patent Office. The applicant was attempting to patent her own genetic sequence, in order to protect it from unauthorised exploitation, whether genetic or otherwise. ${ }^{6}$ The intention was to protest the granting of gene patents, which appeared to allow companies to own parts of people.

There are arguments for and against gene patents. Without patent protection, pharmaceutical companies will not undertake the research to develop genetically based drugs, as they would have no guarantee that they could recoup the enormous costs involved. However, such protection inhibits research, because of the licensing fees that would be involved for non-proprietary agencies. ${ }^{7}$ Restrictive use of patents can result in products or processes embodying the subject of the patent being unavailable to the public, with consequential healthcare harm. The challenge from South Africa to the pharmaceutical patents cartel relating to AIDS drugs demonstrates the political unacceptability of overly aggressive use of patents. The actions of the drug companies were legally permissible and yet point to the ethical issues arising from such patents. ${ }^{8}$

This chapter will consider the appropriateness of applying patent law to biotechnology, given that the rights that are protected by patents usually exclude the person central to the whole enterprise-the human source of the material, who, it is argued, has a property interest in the material once it is excised from the body. Mechanisms to protect this interest and to enable the human sources to obtain a share in the profits made from the utilisation of their property will be considered.

\section{INTELLECTUAL PROPERTY}

\section{A Techniques Used in the Manipulation of Living Organisms.}

Human cells were successfully grown outside the body for the first time in 1951. ${ }^{9}$ The cell line continued to grow and divide indefinitely, providing a constant supply of source material. Since then, many cell lines have been established, with the

\footnotetext{
${ }^{4}$ Eike-Henner W Kluge "Patenting Human Genes: When Economic Interests Trump Logic and Ethics" (2003) 11 Health care anal 119, 120.

5 Andrew Sheard "Patenting human genes: Reflections on the public debate" (2002) 8 J Commercial Biotechnology 235.

${ }^{6}$ Patent available at $<$ http://blather.newdream.net/p/patent.html $>$ (last accessed 1 March 2004).

${ }^{7}$ A R Williamson "Gene Patents: Are They Socially Acceptable Monopolies, Essential for Drug Discovery?” (2001) 6 Drug Discovery Today 1092, 1092.

${ }^{8}$ Michael A Heller and Rebecca S Eisenberg "Can Patents Deter Innovation? The Anticommons in Biomedical Research” (1998) 280 Science 698, 702.

${ }^{9}$ G O Gey, W D Coffman and M T Kubicek "Tissue Culture Studies of the Proliferative Capacity of Cervical Carcinoma and Normal Epithelium” (1952) 12 Cancer Research 264, 264.
} 
benefit that all the cells have the same genetic makeup and thus permit accurate comparison of test results. Hybridoma technology was developed to produce a limitless supply of a particular antibody for use in immune system research. Recombinant DNA technology is commonly referred to as genetic engineering. Such technology involves the manipulation of matter at the sub-cellular level. Genetic disorders occur when a gene sequence has bases, as represented as "letters" misplaced or missing. The identification of dysfunctional genes is the first step to curing or preventing such conditions.

There are four broad types of application of DNA sequences, with respect to patent claims:

The presence of a faulty gene can be detected by techniques based on knowledge of the structure of the gene;

Knowledge of DNA sequences can help identify potential targets in the design of drugs and vaccines;

Gene therapy can enable the replacement of a faulty gene in the body with a normal gene;

Therapeutic proteins can be used as medicines, such as human insulin.

\section{B Patent Requirements}

In New Zealand, patents are governed by the Patents Act 1953, as interpreted by the Courts and the Intellectual Property Office of New Zealand (IPONZ). The basis of the patent system is that whoever has created a novel "invention" that is a "manner of new manufacture", which is of perceived benefit to the community, is granted a monopoly to exploit the creation for a maximum of 20 years. In return for the grant of a patent, the owner must make public a complete description of the invention, so the community can make use of it on the expiry of the monopoly. The system is intended to reward the inventor, while providing for a future benefit to the community. Additionally, it provides incentives to others to invent and innovate.

An innovation will be considered a genuine innovation if it meets the following criteria:

It is new and is a "manner of manufacture". ${ }^{10}$ An invention is considered new if a description of it has not been published, or the invention has not been publicly used before the filing date of the application to patent the invention; ${ }^{11}$

The process must be shown to have a relation, directly or indirectly, to the production or manufacture of a vendible product; ${ }^{12}$

It is an invention.

The scope of "invention" has been widened over time, to include technologies that did not exist when the Patents Act was passed. This extension has been achieved by interpreting "invention" from a policy perspective, rather than by analysis of the

\footnotetext{
${ }^{10}$ Patents Act 1953, s 2(1).

${ }^{11}$ Patents Act 1953, s 13.

${ }^{12}$ Swift and Company v Commissioner of Patents [1960] NZLR 775, 779—780 (SC) Barrowclough CJ.
} 
actual words of the statute. The High Court of Australia held that "vendible" equated to a requirement of "utility in practical affairs." 13 A similar approach was adopted in New Zealand. ${ }^{14}$ Thus, a naturally occurring substance is not an invention, but the discovery of a product of nature and an industrial application of that product is.

A patent will be revoked if:

it lacks an inventive step, as it must not have been obvious to an appropriately skilled person; ${ }^{15}$ or

- it lacks utility, as the inventor must have identified a practical use for the invention. ${ }^{16}$

In addition:

there must be adequate disclosure of the invention; ${ }^{17}$ and

it must not breach any of the exceptions that exclude patentability. ${ }^{18}$

New Zealand is a party to the Paris Convention for the Protection of Industrial Property. Through this convention, the patent system must offer international equivalence in basic rights and protection and Party States must grant the same scope of intellectual property protection to the nationals of other member states as they provide to their own nationals. The World Trade Organisation (WTO) TRIPS agreement requires New Zealand to have a patent system that provides certain minimum levels of patent protection. ${ }^{19}$ Member countries are obliged to provide for biotechnology patents, if patent eligibility criteria are met, with certain exceptions. Articles 27.2 and 27.3 allow parties to exclude from patentability:

- inventions whose commercial exploitation must be prevented for the protection of ordre public or morality, including the protection of human, animal, or plant life or health, or to avoid serious harm to the environment;

- diagnostic, therapeutic, and surgical methods for the treatment of humans or animals; ${ }^{20}$ and

- $\quad$ plants and animals (other than micro organisms) and biological processes for the production of plants and animals.

\section{Review of the Patents Act}

\footnotetext{
${ }^{13}$ NRDC v Commissioner of Patents (1959) 102 CLR 252 (HCA).

${ }^{14}$ Swift and Company $v$ Commissioner of Patents, above.

${ }^{15}$ Patents Act 1953, s 21.

${ }^{16}$ Patents Act 1953, s 41.

${ }^{17}$ Patents Act 1953, s 41.

${ }^{18}$ Patents Act 1953, s 41.

${ }^{19}$ World Trade Organisation Agreement on Trade Related Aspects of Intellectual Property Rights Annex 1C to the Agreement establishing the World Trade Organisation $<$ http://www.wto.org/english/docs_e/legal_e/27-trips_01_e.htm $>$ (last accessed 14 February 2005).

${ }^{20}$ Pharmaceutical Management Agency Limited v Commissioner of Patents [2000] 2 NZLR 529, 529 para 16 (CA) Richardson P, Gault, Keith, Blanchard and Tipping JJ. The prohibition on patenting methods of medical treatment in New Zealand rests solely upon policy and ethical grounds.
} 
The Royal Commission on Genetic Modification was established in 2000 in response to concerns about the potential effects of genetic modification. The Commission presented its report in 2001. ${ }^{21}$ Recommendation 10.2 provides:

That the Patents Act 1953 be amended by adding a specific exclusion of the patentability of human beings and the biological processes for their generation in line with s18 of the Patents Act 1990 (Commonwealth).

The Government agreed that this amendment should be made. ${ }^{22}$ Such exclusion would not prevent research taking place in these areas, and any such restriction would require specific legislation.

Following a review of the Patents Act, the Ministry of Economic Development, did not support the exclusion of genetic material from patentability, because of:

- the large number of genetic material patents that have already been granted;

. $\quad$ the difficulty in defining genetic material;

- the likelihood of inconsistency with New Zealand's international obligations; and

. $\quad$ possible negative effects on the research community. ${ }^{23}$

In this context, "genetic material" includes whole genomes, single genes, or gene fragments. Where gene patents claim isolated genetic materials, the genetic sequences of that material are part of the description of the invention. It does not refer to whole organisms. The focus of the review was on the suitability of genetic material as a patentable subject matter and whether patents on such subject matter are overly broad, rather than the issue of ownership of genetic material.

The Report noted that there are two vehicles for influencing the effects of genetic material patents. The first is to change patent law and the second is to influence how the law is applied. It recommended that the focus should be on the second and stated that more stringent application of the criteria for granting a patent would, in part, address concerns around the patenting of genetic material.

The grant of patents over genetic material was not specifically dealt with in the review, although some of the amendments to the Act agreed to by Cabinet may address some of the concerns. These changes include a stricter utility requirement, by requiring examination for inventive step or obviousness. The Commissioner of Patents will have greater powers to refuse a patent, on a case-by-case basis, if commercial exploitation of the invention would be contrary to morality. The amended Patents Act will expand on the current exclusion of inventions whose commercial

\footnotetext{
${ }^{21}$ Royal Commission on Genetic Modification Report of the Royal Commission on Genetic Modification (Royal Commission on Genetic Modification, Wellington, 2001) $<$ http://www.gmcommission.govt.nz> (last accessed 10 March 2004).

${ }^{22}$ Ministry of Economic Development Review of the Patents Act 1953 Stage 3: Boundaries to Patentability (MED, Wellington, 2003) para $142<$ http://www.med.govt.nz $>$ (last accessed 17 September 2004).

${ }^{23}$ Ministry of Economic Development Memorandum to Cabinet Policy Committee: Report Back with Recommendations and Options for Addressing Genetic Material Patents (MED, Wellington, 2004) available at <http://www.med.govt.nz $>$ (last accessed 15 September 2004).
} 
exploitation would be contrary to morality or "ordre public", to include "where the prevention of such exploitation is necessary to protect human, animal or plant life or health or to avoid serious prejudice to the environment." ${ }^{24}$ It will also be possible to revoke a granted patent on this ground. This exclusion could be invoked where the Patents Commissioner felt there were strongly held ethical or moral objections to the commercial exploitation of a particular gene, or application involving a gene.

There has been much discussion as to whether human DNA patents are contrary to public morality and whether the Commissioner of Patents should determine matters of morality in a pluralistic society. ${ }^{25}$ Examination for obviousness will reduce the likelihood of patents being granted over genetic material or applications of genetic material that are no more than obvious variations on what is already known. Changes to the utility requirement mean that patents will not be granted unless the invention is shown to have a "substantial, credible and specific" use. This makes it less likely that patents will be granted over genetic material that has no demonstrated "real world" use. The patent will still cover all uses to which the patented gene can be put, even though the patent application may have identified only one use for the genetic sequence.

\section{$1 \quad$ Human being}

If patenting humans is to be prevented, the definition of a human being is a major issue. ${ }^{26}$ The definition would need to specify the stage of development at which a human being comes into existence, and whether parts of the body, such as organs, cells and cell lines are patentable. MacBean argues: ${ }^{27}$

If a definition of human being is adopted that restricts the meaning of the term to an organism at birth and beyond, then public access to the widest range of technologies is more likely to occur.

This thesis proposes that personhood commences when a child is "born alive". ${ }^{28}$ This would allow the patenting of biological material, such as DNA sequences, and encourage the development of techniques and products using such material.

A broad definition of a human being would include human biological material including cells, genes and gene fragments and the like, as well as human beings as entire organisms. Such a view was advanced by Mosk J, in his dissenting opinion in Moore ${ }^{29}$ when he stated that no physical distinction existed between Moore's cells and the cell-line, as the cell line merely extended the life of the cells. ${ }^{30}$ In the human body, the components of the functional genetic units are all integral parts of the same biological mechanism that interacts with other gene products. If the DNA sequences

\footnotetext{
${ }^{24}$ Ministry of Economic Development Review of the Patents Act 1953 Stage 3: Boundaries to Patentability (MED, Wellington, 2003) para $50<$ http://www.med.govt.nz $>$ (last accessed 17 September 2004).

${ }^{25}$ R Crespi “An Analysis of Moral Issues Affecting Patent Inventions in the Life Sciences: A European Perspective" (2000) 6 Science and Engineering Ethics 157, 157.

${ }^{26}$ See the discussion of personhood in chapter 4.

${ }^{27}$ Alexandra MacBean "The Patentability of Human Beings: The Effect of a Proposed Exclusion in the Patents Act 1953” (2002) 33 VUWLR 379, 380.

${ }^{28}$ As discussed in chapter 4.

${ }^{29}$ Moore v Regents of the University of California (1990) 793 P 2d 479, 494 (Sup Ct Cal).

${ }^{30}$ Moore $v$ Regents of the University of California, above, 511
} 
of all components are separately patented, any useful product is likely to cross the boundaries of several patents and thus, reduce the cost effectiveness of the product. As stated by MacBean, the fundamental issue is whether the inventor's intellectual property rights should extinguish whatever proprietary rights a donor retains in donated body parts. ${ }^{31}$

\section{Opposition to Patenting of Genes} include:

The reasons that are commonly advanced to oppose the patenting of genes

As a gene exists in nature, it is not novel and, consequently, not patentable;

The isolation of a gene does not involve inventing or discovering anything;

Determining the structure of a gene is, at most, a discovery, rather than an invention; and

Sequencing a gene has become a routine automated process that is not inventive.

Inventive step

It has been suggested that a researcher who isolates a genetic compound has not taken any inventive step. The Human Genetics Society of Australasia stated that the initial premise that DNA sequences may be patented is flawed, because human genetic material is a naturally occurring substance, present in all human beings, and has evolved over many generations. ${ }^{32}$ It accepted that a process to discover or isolate a sequence of DNA may be novel and inventive, but questioned how this can apply to the structure itself. It pointed to an inconsistency if the law does not allow the patenting of a human being, yet it would be feasible to acquire from the patent holders all patents for all existing genes in the entire human genome. The purchaser would then hold the "blueprint" of a human being.

As stated by Kluge: ${ }^{33}$

To grant a patent for a human gene is not to grant a right to the material substance that was extracted from the original DNA and amplified by polymerase chain reaction. It is to grant a right to the pattern, nature or code of the material substance itself....while it may be appropriate to recognize private ownership of the material quantities of genes that have been isolated through a particular process, and while it may be appropriate to permit someone to patent the particular isolating process itself, this is quite different from recognizing intellectual or other property rights in the individual genes as pieces of structural biology code.

At present, a wide variety of genetic material is patentable, but a revised definition of inventorship might resolve many of the concerns of the contributors of biological material, who argue that identifying the chemical sequence of the isolated

\footnotetext{
${ }^{31}$ MacBean, above, 388. This point is expanded later in this chapter.

${ }^{32}$ Human Genetics Society of Australasia Response to ALRC: Issues Paper 27 Gene Patenting and Human Health (Human Genetics Society of Australasia, Victoria, 2003) $2<$ http://www.hgsa.com.au> (last accessed 1 April 2004).

${ }^{33}$ Eike-Henner W Kluge "Patenting Human Genes: When Economic Interests Trump Logic and Ethics" (2003) 11 Health Care Analysis 119,122.
} 
compound is no more inventive than their contribution of the biological raw materials used in the research process.

The definition of a patentable invention in section 2 of the Patents Act 1953 does not specifically exclude biotechnological inventions, although IPONZ does have a practice of refusing patents that would include human beings within their scope, on the grounds that such applications do not constitute a "manner of manufacture". 34 However, patents with respect to animals have been granted. ${ }^{35}$ Both gene sequences and non-human living organisms are patentable. ${ }^{36}$ At present, Australian and New Zealand law allows the patenting of genes and gene sequences when specific criteria have been met, and patents have been awarded for complete genes of known function and usefulness. The Ministry of Economic Development agreed with the recommendations of the House of Commons Select Committee on Science and Technology, that a gene sequence should only be patentable in the context of a specific utility, and that the same sequence should be available for further patents by others in the context of other utilities, rather than conferring rights over the gene itself. $^{37}$ This was because granting of excessively broad patents may give undue reward for small contributions, inhibit the speed of exchange of basic knowledge and prevent the development of useful products.

\section{$2 \quad$ Novelty}

The requirement of novelty is intended to ensure that a patent is not granted over anything that is already in the public domain. This is ascertained by an examination of current knowledge-the state of the art. If the invention has been anticipated by publication of its contents, then no patent will be granted. Additionally, the invention must not be obvious to a person skilled in the particular art, in that it must not be an example of the normal progress of knowledge that does not demonstrate particular skill on the part of the inventor. The invention must be of practical application or benefit to the community and must be disclosed in such a manner that allows repeatability by someone with skills in the appropriate art.

The patent on breast cancer genes BRCA1 and BRCA2 has been revoked by the European Patent Office. ${ }^{38}$ Women who have specific faults in the genes, about five per cent of the population, are especially prone to breast cancer. Screening tests can identify the faults, but a payment to the patent holder, Myriad Genetics, was required. The decision will enable cheaper screening in Europe, as Myriad can no longer levy a licence fee for screening tests that use the gene.

The primary reason for the decision was that the application was not deemed "inventive." Opponents of the patent had discovered discrepancies of about 10 DNA letters between the BRCA1 gene sequence described in Myriad's patent, which was

\footnotetext{
${ }^{34}$ Ministry of Economic Development Review of the Patents Act 1953 Stage 3: Boundaries to Patentability (Ministry of Economic Development, Wellington, 2003) $30<\mathrm{http}$ :/www.med.govt.nz> (last accessed 14 February 2004).

${ }^{35}$ Such as New Zealand patent 243908 which relates to a transgenic mouse.

${ }^{36}$ Ministry of Economic Development, above, 34.

${ }^{37}$ Ministry of Economic Development Memorandum to Cabinet Policy Committee: Report Back with Recommendations and Options for Addressing Genetic Material Patents (Ministry of Economic Development, Wellington, 2004) <http://www.med.govt.nz> (last accessed 15 September 2004).

${ }^{38}$ Andy Coghlan "Europe Revokes Controversial Gene Patent" (19 May 2004) NewScientist.com news service < http://www.newscientist.com> (last accessed 27 May 2004).
} 
issued in 2001, and the sequence in Myriad's original 1994 patent application. In 1995, Myriad submitted an updated sequence, exactly matching the one in the issued patent. By then, the crucial sequence had already been published openly elsewhere, which made it unpatentable because of lack of inventiveness. This decision is significant as, apart from the economic implications for breast cancer screening in Europe, it could increase pressure on the United States Patent and Trademark Office to reject or revoke "obvious" gene patents.

\section{Usefulness}

A requirement for an invention to be "useful" before a patent was able to be granted would restrict the present practice in the United States of granting patents for large numbers of gene sequences without describing any uses for them, in the hope that anyone who devised a use would be required to pay royalties. In most cases, it is the protein products and their derivatives and antagonists, rather than the encoding DNA, that hold the promise of medical benefits. ${ }^{39}$ A patent is not required to be useful, although the patent can be denied if the application identifies no use at all for the invention. ${ }^{40}$ Lack of usefulness is a ground for revoking a patent, ${ }^{41}$ but there are costs involved in attempting to have a patent revoked, which may exceed the costs of accepting the patent and paying a licence fee to the patent holder.

\section{$4 \quad$ Products of nature}

Biotechnical inventions create difficulties in the areas of patenting "products of nature" and disclosure. This broadly means that nothing that occurs in nature should be the subject of a patent application, because an invention should be more than a discovery. The patent system is intended to reward skill, effort and endeavour. Cornish states: "Discovery is the unearthing of causes, properties or phenomena already existing in nature; invention is the application of such knowledge to the satisfaction of social needs." 42

A further argument is that products of nature are the property of all mankind and, as such, should not fall into the ownership of any one individual or group. ${ }^{43}$ If applied strictly, this argument would prevent the patenting of biotechnology inventions, as they involve the manipulation of naturally occurring organisms. However, it has long been possible to obtain patents for chemical substances that occur in nature, because such patents only relate to the substance when isolated and purified, and the substance does not exist in nature in the purified form. Once purified and isolated, it is then in a useful form.

Patents on genes, genetic sequences and genetically engineered organisms have generated controversy since the United States Supreme Court allowed the patenting of a genetically engineered micro-organism to degrade petroleum spills. ${ }^{44}$ This was the first case in which a living organism was the subject of a patent. Since

\footnotetext{
${ }^{39}$ Martin Bobrow and Sandy Thomas "Patents in a Genetic Age" (2001) 409 Nature 763, 764.

${ }^{40}$ General Electric Co Ltd's Application (Patent), above, 21.

${ }^{41}$ Patents Act 1953, s 41(1)(g).

${ }^{42}$ W R Cornish Intellectual Property: Patents, Copyright, Trade Marks and Allied Rights (Sweet and Maxwell, London, 1989) para 5-041.

${ }^{43} \mathrm{~S}$ A Bent and others Intellectual Property Rights in Biotechnology Worldwide (Macmillan, Basingstoke, 1987) 115-6.

${ }^{44}$ Diamond v Chakrabarty (1980) 447 US 303, 309.
} 
then there have been a variety of other such patents, such as the patenting of the Harvard oncomouse in 1987, the cell line from John Moore, and patents on genes and cell lines of various indigenous peoples. ${ }^{45}$

Proponents of gene patents point to the statement in Diamond $v$ Chakrabarty ${ }^{46}$ that "anything under the sun that is made by man" can be patented. ${ }^{47}$ However, the Court qualified the statement by reiterating the statutory requirements for a gene patent, and stated that manifestations of nature were not patentable. Applicants for gene patents assert that they have isolated and purified genes, because genes in the body have both coding and non-coding regions, whereas the patented genes have been manipulated to eliminate the non-coding region, while still performing the same function as a naturally occurring gene. Thus, as a gene is a chemical substance in the form of a DNA molecule, an isolated and purified DNA molecule that has the same sequence as a naturally occurring gene is patentable, because the DNA molecule does not exist in nature in an isolated and purified form. ${ }^{48}$

Patents have been essential for drug development, to attract the capital necessary for the expense involved in the creation and testing. ${ }^{49}$ The discovery of a gene does not require these incentives. There are no expensive clinical trials required, as knowledge about the sequence of the gene is used to identify whether an individual has a mutation of that gene.

As stated by Andrews: "Gene patents do not seem necessary to encourage technology transfer in the move from gene discovery to the availability of a genetic diagnostic test." 50 She gives, as an example, the experience of the hemachromatosis gene. Once the gene was discovered, laboratories began testing for mutations. However, once a patent on the gene was granted 17 months later, 30 per cent of the laboratories discontinued testing, or did not develop a test for the disease. The patent holder was asking a fee of \$US25,000 from academic laboratories, plus a fee of \$20 per test. The patent interfered with the clinical adoption of the test and potentially, affected the quality of the testing, by limiting the development of better quality, or lower cost, alternative tests. ${ }^{51}$ Furthermore, although researchers can invent alternative drugs or medical devices, there are no alternatives to using the patented human genes in genetic diagnosis and gene therapy.

It has been argued that there is more justification for patent protection in the area of identification of genes used to diagnose or predict the occurrence of common

\footnotetext{
${ }^{45}$ V Brower "Mining the Genetic Riches of Human Populations" (1998) 16 Nature Biotechnology 337, 337.

${ }^{46}$ Diamond $v$ Chakrabarty, above.

${ }^{47}$ Diamond $v$ Chakrabarty, above, 309.

${ }^{48}$ Ministry of Economic Development Review of the Patents Act 1953 Stage 3: Boundaries to Patentability (Ministry of Economic Development, Wellington, 2003) $34<$ http://www.med.govt.nz> (last accessed 14 February 2004).

${ }^{49}$ It is estimated that the cost of developing a new drug to the marketable stage, is around \$US802 million Tufts Center for the Study of Drug Development News Release "Tufts Centre for the Study of Drug Development Pegs Cost of a New Prescription Medicine at $\$ 802$ million" (30 November 2001) $<$ http://csdd.tufts.edu> (last accessed 18 February 2005).

${ }^{50}$ Lori B Andrews "The Gene Patent Dilemma: Balancing Commercial Incentives With Health Needs" (2002) Hous J Health L \& Pol'y 65, 77.

${ }^{51}$ Andrews, above, 78.
} 
diseases. $^{52}$ Many genes, each exerting a small effect, may be involved. As such research is more expensive than research into conditions associated with a single gene, it is suggested that without patent protection, private investment into such research will abate, resulting in the failure to develop diagnostic tests. The alternative point of view is that such diagnostic tests involve multiple analyses of many genes, or marker regions of DNA, that are closely associated with genes. Such research may be obstructed by the grant of numerous patents claiming DNA sequences and lead to a requirement to negotiate licenses to enable simultaneous testing for more than one disorder. The effect is to inhibit, rather than facilitate, the development of tests. The Nuffield Council recommended that the criteria of inventiveness be stringently applied to applications for product patents which assert, inter alia, rights over DNA sequences for use in diagnosis. ${ }^{53}$

\section{PROFIT}

Patent protection is intended to support and increase investment in the development of new therapies. The investment is premised on profitability, which in turn leads to health gains. One effect of patent enforcement is that the resultant products or processes may be kept out of the marketplace or may be excessively expensive, thus denying them to the public, or the patent holder may refuse to allow access. This is apparent in countries such as New Zealand, with publicly funded health systems, where budgetary constraints may preclude the payment of the monopoly price. Patents can have a profound effect on health policy and access to genetic services.

Priorities in healthcare research will be directed toward profitable areas that relate to the more common conditions, as the resultant products are likely to have a large market. Such conditions may be related more to consumer desires than to health outcomes, resulting in the more obscure conditions receiving little research attention. Once a patent is held on a gene, other researchers and biotechnology companies will be deterred from product development relating to that gene and so development is dependent on the institution or scientist holding the patent. Such decisions are likely to be made on economic, rather than health grounds.

\section{MULTIPLE PATENTS}

By early 2000, Incyte Pharmaceuticals Inc had filed applications on 1.2 million partial gene fragments. ${ }^{54}$ The patenting of small sections of genes, such as Express Sequence Tags (ESTs), results in a need to negotiate with the holders of multiple patents before research is able to proceed, and so discourages innovation. The hurdles of novelty, non-obviousness and usefulness were countered by asserting that partial gene sequences could be useful as a marker to locate the full gene, or as a unit of analysis to understand evolution.

Broad patent rights are said to foster innovation, but in this case the effect has been to stifle competition, with a deleterious effect on innovation. As stated by Heller

\footnotetext{
${ }^{52}$ Nuffield Council on Bioethics The Ethics of Patenting DNA (Nuffield Council on Bioethics, London, 2002) $52<$ www.nuffieldbioethics.org > (last accessed 1 April 2004). The Review of the Patents Act 1953 reached the same conclusion.

${ }^{53}$ Nuffield Council on Bioethics, above, 53.

${ }^{54}$ Lori B Andrews "The Gene Patent Dilemma: Balancing Commercial Incentives with Health Needs" (2002) Hous J Health L \& Pol'y 65, 83.
} 
and Eisenberg: "A proliferation of intellectual property rights upstream may be stifling life-saving innovations further downstream in the course of research and product development." ${ }^{, 55}$ The Nuffield Council recommended that when rights are asserted in terms intended to cover all sequences that contain the EST that is the subject of the original patent, no patent should be granted. ${ }^{56}$ The Council welcomed the Utility guidelines for DNA sequences introduced by the United States Patent and Trademark Office which have, in effect, been endorsed by the European Patent Office. $^{57}$

The Ministry of Economic Development has recommended that a gene sequence should only be patentable in the context of a specific utility, and that the same sequence should be available for further patents by others, in the context of other utilities, rather than conferring rights over the gene itself. ${ }^{58}$ It states that the granting of excessively broad patents may give undue reward for small contributions and inhibit the speed of exchange of basic knowledge and the development of useful products. Thus, it suggests clearly defining the patentable subject matter, to exclude broad-based genetic patents covering multiple potential uses and limiting patents to clear and well-defined specific uses.

\section{RESEARCH OR TREATMENT USE}

A researcher seeking a cure for breast cancer would be required to negotiate not only with the patent holder for the full BRCA1 and BRCA2 genes, but also with all the other patent holders who had discovered and patented any of the other of the hundreds of mutations in that gene, with the risk of any one patent holder being able to veto any negotiation. The United States does not have an explicit research exception in its patent law, to enable research to proceed without patent permissions, but European patent law allows researchers in commercial and non-commercial environments to use a patent invention in their research without violating the patent. ${ }^{59}$ In Japan, the broad exemption has not impeded its strong biotechnology industry. ${ }^{60}$

A patent is not infringed by the making of the patented articles for a bona fide experiment to make improvements, but making for the purpose of sale or other use would infringe the patent. The Human Genetics Society of Australasia recommended that the Patents Act be amended to allow a defence for research use. ${ }^{61}$ They stated that such defence should be limited to research on an invention claimed in a gene patent.

\footnotetext{
${ }^{55}$ Michael A Heller and Rebecca S Eisenberg "Can Patents Deter Innovation? The Anticommons in Biomedical Research" (1998) 280 Science 698, 701.

${ }^{56}$ Nuffield Council on Bioethics The Ethics of Patenting DNA (Nuffield Council on Bioethics, London, 2002) $58<$ www.nuffieldbioethics.org $>$ (last accessed 1April 2004).

${ }^{57}$ USPTO Utility Examination Guidelines Fed. Reg. 66:1093 5 Jan 2001

$<$ http://www.uspto.gov/web/offices/com/sol/notices/utilexmguide.pdf> (last accessed 2 April 2004).

${ }^{58}$ Ministry of Economic Development Memorandum to Cabinet Policy Committee: Report Back with Recommendations and Options for Addressing Genetic Material Patents (Ministry of Economic Development, Wellington, 2004) para $44<$ http://www.med.govt.nz $>$ (last accessed 15 September 2004).

${ }^{59}$ Rebecca S Eisenberg "Patents and the Progress of Science: Exclusive Rights and Experimental Use" (1989) 56 U Chi L Rev 1017, 1018-1019.

${ }^{60}$ Janice M Mueller 'No 'Dilettante Affair': Rethinking the Experimental Use Exception to Patent Infringement for Biomedical Research Tools" (2001) 76 Wash L Rev 1.

${ }^{61}$ Human Genetics Society of Australasia Response to ALRC: Issues Paper 27 Gene Patenting and Human Health (Human Genetics Society of Australasia, Victoria, 2003) <www.hgsa.com.au> (last accessed 1 April 2004).
} 
The reason was the difficulty in determining whether uses are truly research uses, or whether they have commercial implications. They suggested that it might be more appropriate to limit a research defence and use other defences instead, such as a clinical use defence. This would allow claimed inventions to be used in clinical research, without infringing the patent.

The Ministry of Economic Development has recommended that a clearly defined research exemption be added to the Patents Act and Cabinet has agreed that an experimental use exception will be incorporated into the Patents Bill. ${ }^{62}$ The circumstances in which the exemption may be used will be clearly defined to provide certainty for researchers and patent owners. The exemption will have to be consistent with New Zealand's obligations under the TRIPS Agreement, in particular Article $30 .{ }^{63}$

Exclusion of diagnostic, therapeutic, or surgical methods of treatment from the scope of patents would create definition difficulties in determining whether medical treatment includes diagnosis and treatment. A test to determine whether a person is predisposed to future manifestation of illness is not medical treatment, in the sense of ameliorating an existing condition in the patient, although it may fall within the ambit of preventative medicine, as the patient may adopt practices to minimise the likelihood of the diseases developing, or seek early treatment.

Cabinet has agreed to an exclusion from patentability for "diagnostic, therapeutic and surgical methods for the treatment of humans." ${ }^{64}$ Internationally, courts and patent examiners apply a narrow, technical interpretation of such exclusions, because they constitute an exception. Thus, diagnosis that takes place outside the body, for example, a blood or genetic test, is treated as patentable.

\section{POTENTIAL SOLUTIONS}

\section{A Licensing}

Once patents have been granted, others may purchase a licence to use the patented invention. Patent holders may refuse a licence, or may propose an excessive licence fee. The Nuffield Council suggested that, as genetic information cannot readily be "invented around", compulsory licensing may be justifiable if the monopoly enjoyed is such that an important diagnostic tool is not practically available. ${ }^{65}$ The Government could override the patent holder's complete control by compulsory licensing, if a patent holder refuses to license on reasonable terms. ${ }^{66}$ The policy question is whether the disadvantages of reducing patent protection outweigh the beneficial effects.

\footnotetext{
${ }^{62}$ Expected to be introduced in Parliament in late 2006.

${ }^{63}$ Ministry of Economic Development Memorandum to Cabinet Policy Committee: Report Back with Recommendations and Options for Addressing Genetic Material Patents (Ministry of Economic Development, Wellington, 2004) para $44<$ http://www.med.govt.nz $>$ (last accessed 15 September 2004).

${ }^{64}$ Cabinet Minute "Granting patents Over Genetic Material” 2003 CAB Min (03) 25/4.

${ }^{65}$ Nuffield Council on Bioethics The Ethics of Patenting DNA (Nuffield Council on Bioethics, London, 2002) $55<$ www.nuffieldbioethics.org > (last accessed 1April 2004).

${ }^{66}$ Patents Act 1953, s 46.
} 
The Human Tissue Authority could set the price, allowing for a reasonable fee to be paid to the patent holder and, in certain circumstances, to the original source of the body samples. As stated by Caulfield: ${ }^{67}$

Such an approach provides policy makers with an explicit tool to balance the goal of stimulating innovation and controlling the impact of patents on health care policy. Patent holders would still retain a right to profit and a limited monopoly control over the 'genetic invention' but the government could ensure that the needed genetic service was accessible within the health care system at a reasonable price.

The TRIPS Agreement allows compulsory licensing under certain circumstances. It provides for flexibility, including members' rights to grant or determine the grounds for granting compulsory licences, and to define a condition of national emergency, or other circumstance of extreme emergency. The declaration also called for the TRIPs Council to address the problems that WTO members with restricted manufacturing capacities in the pharmaceutical sector may have, in making effective use of compulsory licensing under TRIPs.

\section{B Inventorship}

If the human sources of biological research materials wish to control the subsequent uses of their contributions, inventorship is a primary issue. If they were the inventors, or joint inventors, of the invention, they could issue licences to use it, even over the objections of other joint inventors. They could thereby defeat the ability of the other joint inventor to sue for patent infringement, or charge excessive licensing fees. In the Canavan case, if the contributors were joint inventors, they could have provided licences to the laboratories wishing to use the patented genetic test and, thereby, protect the laboratories from being sued for patent infringement.

The first step in invention is conception, which is the intellectual component. It involves the formulation of a mental picture of the invention, which is sufficiently definite that another, adequately skilled person could understand the invention. It involves more than a general intention or research plan. Although the human source of the materials may have been vital to the research enterprise, invention does not relate to those who assist. The person who provides the genetic raw material fails to satisfy the requirement of novelty and would lack the requirement for the conception of the chemical components of the isolated genetic material. Thus, the scientists created the cell line based upon Moore's cells, but the artificially created cell line was not a function of Moore's own mental processes. Additionally, the patent did not claim Moore's cells, because discoveries of naturally existing compounds would fail to meet the novelty requirement. Thus, a claim by Moore to have invented the cell line, or to have a patentable invention in his cells, would fail. Similarly, the families involved in the Canavan research could not claim inventorship of the patent, nor did they attempt to do so. ${ }^{68}$

\section{Joint inventorship}

In light of present patent law, it is unlikely that the contributors of biological material have contributed sufficiently to be entitled to joint inventorship. In Brown $v$

\footnotetext{
${ }^{67}$ T A Caulfield and others "Genetic Technologies, Health Care Policy and the Patent Bargain" (2003) 63 Clin genet $15,17$.

${ }^{68}$ See the discussion in chapter 3 .
} 
Regents of the University of California, ${ }^{69}$ Brown claimed to be the co-discoverer of the feline FIV virus that was used to develop patented diagnostic methods for FIV. She claimed that her contribution was observing that her cats had symptoms similar to those in human AIDS and bringing them to researchers for study. The Court concluded that Brown "at most played a substantial role in the discovery of FIV", 70 but discounted her role for patent purposes. The patents not only claim discovery of the FIV virus but claim "isolation and substantial purification of the virus, as well as methods for diagnosing the virus by detecting the presence of the virus itself...." Brown's role in the patented product was minimal, and she had not contributed to the conception of the inventions covered by the patents.

In Moore, ${ }^{71}$ Mosk $\mathrm{J}$ argued that the spirit of joint inventorship should apply to persons such as Moore, whether or not they fell literally within patent law. ${ }^{72} \mathrm{He}$ suggested that "the joint invention provision guarantees that all who contribute in a substantial way to a product's development benefit from the reward that the product brings." ${ }^{73}$ Whilst accepting that the provider of the biological materials did not further the invention in any intellectual or conceptual sense, he stated: ${ }^{74}$

\begin{abstract}
What the patients did do, knowingly or unknowingly, is collaborate with the researchers by donating their body tissue. By providing the researchers with unique raw materials, without which the resulting product could not exist, the donors became necessary contributors to the product.
\end{abstract}

Although reflecting a common public perception of the source's role, this argument fails to take into account the necessity that joint inventors participate in the actual invention itself.

\title{
D Causation
}

The people who provide the research materials could argue that they were the factor that lead to the patented invention, or that the inventor would not have been possible without their contribution. However, the counter to this argument is that the biological materials are not patented. That which is claimed under the patent is different from that which they contributed.

\section{PROPERTY RIGHTS}

Patients and research subjects should have the right to determine whether or not their genes are patented and what uses are made of them. In the United States, the American Medical Association's Code of Ethics requires that the consent of a patient be obtained before products developed from their genetic material can be commercialised. ${ }^{75}$ The European Parliament's Directive on the Legal Protection of Biotechnological Inventions states that if a patent application uses material of human origin, the source must have had the opportunity to give informed consent and so, has

\footnotetext{
${ }^{69}$ Brown $v$ Regents of the University of California (1994) 866 F Supp 439 (DN Cal).

${ }^{70}$ Brown $v$ Regents of the University of California, above, 445.

${ }^{71}$ Moore $v$ Regents of the University of California (1990) 51 Cal 3d 120 (Cal Sup Ct).

${ }^{72}$ Moore $v$ Regents of the University of California, above, 168-69.

${ }^{73}$ Moore $v$ Regents of the University of California, above, 169.

${ }^{74}$ Moore $v$ Regents of the University of California, above.

${ }^{75}$ American Medical Association, Council on Ethical and Judicial Affairs Code of Medical Ethics: Current Opinions with Annotations (American Medical Association, Chicago, 2000) 25-26

$<$ http://www.ama-assn.org > (last accessed 12 February 2005).
} 
the right to refuse to have genes patented. ${ }^{76}$ The Netherlands ${ }^{77}$ brought an action ${ }^{78}$ seeking annulment of Directive 98/44/EC on the Legal Protection of Biotechnological Inventions. ${ }^{79}$ One of the grounds for the application was that the Directive breaches fundamental rights, by failing to provide for the free and informed consent of the donor of human biological material, prior to an application to patent inventions that have been developed from, or using, such material. Although the Directive requires patent examiners to satisfy themselves that proper informed consent was obtained, the European Court of Justice ruled that such requirements, although involving matters of fundamental right, do not fall within patent law, as rigorous scrutiny of informed consents within the patent system would be a burden for the system and inconvenient for researchers.

The House of Lords Select Committee on Stem Cell Research stated that it is not good policy to introduce commercialisation upstream from the point at which the inventive research work takes place. ${ }^{80}$ The Committee reasoned: ${ }^{81}$

\begin{abstract}
It has been suggested that those who donate an embryo for stem cell research might subsequently expect a share in any benefits accruing from commercial exploitation of research on stem cell lines derived from it. In our view it would be undesirable for legislation to permit such claims: any commercial benefits will have come about as a result of the research and subsequent development rather than any intrinsic quality of a particular embryo donated. However, it makes it even more important that potential donors should fully understand the implications if embryos they are donating may be used for the production of stem cell lines, and in particular that the material donated may be used for a purpose other than the immediate one.
\end{abstract}

The Committee's position implies that the gamete providers have an interest in the embryo. ${ }^{82}$ Additionally, it accepts that research will lead to commercial exploitation and, as in Moore, ${ }^{83}$ is concerned to ensure that the gamete sources do not profit from such commodification. The Committee recommended that the implications of stem cell line immortality should be made clear to donors and donations should be free of specific constraints, by the giving of blanket consents. ${ }^{84} \mathrm{~A}$ person cannot give informed consent to processes and uses not yet in existence, and perhaps not even within the contemplation of present researchers, so this amounts to uninformed consent, or an unconditional transfer of the property.

The Nuffield Council on Bioethics suggests that the law has tended to be generous in granting patents relating to DNA sequences, because of the broad scope of many of the patents and the weak application of the criteria for inventiveness and

\footnotetext{
${ }^{76}$ European Parliament Directive on the Legal Protection of Biotechnological Inventions Directive 98/44/EC (European Parliament, Strasbourg, 1998) <http://www.europarl.eu.int> (last accessed 1 April 2005).

${ }^{77}$ Kingdom of the Netherlands v European Parliament and Council of the European Union case C377/98 [2000] ECR I-6229.

${ }_{78}$ under article 230EC (ex Article 173EC)

${ }^{79}$ European Parliament, above.

${ }^{80}$ Stem Cell Research HL Paper 83(i) (Report) and 83(ii) (Evidence) (HMSO, London, 2002).

${ }^{81}$ Stem Cell Research, above, para 8.32.

${ }^{82}$ See the discussion in chapter 4.

${ }^{83}$ Moore v Regents of the University of California (1990) 51 Cal 3d 120 (Cal Sup Ct).

${ }^{84}$ Stem Cell Research, above, para 8.33.
} 
utility. ${ }^{85}$ Similarly, Frankel and McLay note that IPONZ registers patents, even if registerability is in doubt, applying the rule that a patent application should only be refused if it could not be patentable on any reasonable interpretation of the law. ${ }^{86}$

Gene patenting appears to legitimise ownership and control over something that was not created by the claimant-no work went into the construction of the gene itself, it was merely removed from the DNA matrix in which it naturally occurs. A successful patent of a DNA sequence provides broad protection on all uses of the DNA and sometimes the proteins that the DNA produces, because inventors are entitled to property rights, not only to the uses of the invention that they anticipated or predicted, but to any new uses that are developed.

However, to state that the source of the biological materials has a property interest in the resulting patent may not entirely resolve the problems of biological patents. Only in very infrequent circumstances will a person have a unique biology, as did Moore, necessitating the acquisition of materials from a particular individual. In common complex genetic diseases, many people are likely to have the particular mutation. The researchers will not need to collect DNA from individual donors if they are able to access samples that are retained in biobanks. However, this thesis argues that such collections should not be available for unconsented research, at least with regard to future collection of samples. ${ }^{87}$

\section{A Contribution approach}

Joint ownership of patents could be refined to include the sources of the biological materials. Ho suggests differing ownership interests, based on the amount of contribution. She states: ${ }^{88}$

[I]f all contributors were provided partial ownership interests, rather than the current control provided to joint inventors, patients may have less control over the total outcome than under the traditional joint inventorship and ownership model. Nonetheless, a modified contribution standard may be a much more realistic option.

Joint inventorship is a difficult threshold for sources to meet, but a contribution standard might be more easily satisfied. Partial ownership rights would not give total control to sources, but providing limited rights would begin to address some of the current problems of public distrust of science.

\section{B Patent unenforceability}

Legislation should specify that, if a patent was obtained without the proper informed consent of the contributors, the patent, as a matter of equity, is unenforceable. Such a suggestion was mooted by Mosk J, when he stated that a patent is not a licence to defraud. ${ }^{89}$ However, most contributors are aware of their

\footnotetext{
${ }^{85}$ Nuffield Council on Bioethics The Ethics of Patenting DNA (Nuffield Council on Bioethics, London, 2002) <www.nuffieldbioethics.org> (last accessed 1 April 2004).

${ }^{86} \mathrm{~S}$ Frankel and G McLay Intellectual Property in New Zealand (Lexis Nexis Butterworths, Wellington, 2002) 327.

${ }^{87}$ See the discussion in chapter 3 about rule 7(10) and the proposals in chapter 8 .

${ }^{88}$ Cynthia Ho "Who Deserves the Patent Pot of Gold?: An Inquiry into the Proper Inventorship of Patient Based Discoveries" (2002) Hous J Health L \& Pol'y 107, 159.

${ }^{89}$ Moore $v$ Regents of the University of California (1990) 51 Cal 3d 120, 168 (Cal Sup Ct).
} 
involvement in the research but fail to understand the patent implications, as happened with the Canavan research. Unenforceability may be particularly justified where there has been an element of fraud in the obtaining of the research materials.

\section{The Shop Right Doctrine}

Pennisi suggests that the shop right doctrine may provide a solution. ${ }^{90}$ This doctrine provides that an employee who makes an invention on the employer's time, using the employer's resources, implicitly grants the employer a limited non-exclusive royalty-free licence to use, make and sell that invention, which continues for the entire term of the patent, even if the employee leaves the employment. The employee retains all other aspects of the patent's right to exclude, including ownership, licensing, and the right to sue for infringement. This is not dependent on a pre-existing contract to this effect and the extent of the right is dependent on the degree of the employer's contribution, in terms of labour and capital.

Pennisi envisages that the doctor/researcher would assume the role of the employee, with the extent of the right limited by the degree of inventive effort required to transform the human source's tissue into the invention, balanced against the rarity of the cells. The shortcomings of this model are that there is no analogue to the usage of an employer's tools or physical plant, and the human source bears none of the financial risks of the inventive process. Even a limited shop right in a patented cell line is, potentially, a lucrative intellectual property holding. However, the human source is unlikely to have the ability or facilities to make and use the invention.

The shop right doctrine was traditionally associated with inventions related to the employer's business. So, unless it was accepted that a person's desire to profit from bodily tissues is a business interest, a person in Moore's position will be unlikely to be able to share in the profits, in the absence of a contract for limited rights in any inventions made at the pre-invention stage. However, in the Canavan families' situation, there was a nexus between their approach to the researcher and the actual inventive process.

\section{Contract}

An alternative construct to obtain rights for the contributors of genetic materials is to use the law of contract. Human sources could contract for partial assignment of ownership rights, even if they cannot successfully assert joint inventorship. Attempts by human sources to protect their position by way of contractual negotiations face difficulties, as the parties are not negotiating on an equal footing, and sources have no way of realistically assessing the potential value of the materials. ${ }^{91}$ There have been suggestions that there should be a global bio-collecting organisation to integrate such efforts at negotiation and enhance bargaining power

\footnotetext{
${ }^{90}$ Christopher S Pennisi "More on Moore: A Novel Strategy for Compensating the Human Sources of Patentable Cell-Line Inventions Based on Existing Law" (2001) 11 Fordham Intell Prop Media \& Ent LJ 747, 767.

${ }^{91}$ Contractual arrangements are expanded later in this chapter.
} 
during contractual negotiations. ${ }^{92}$ The Convention on Biological Diversity promotes the sharing of research results, stating that member States should take: ${ }^{93}$

[L] egislative, administrative or policy measures...with the aim of sharing in a fair and equitable way the results of research and development and the benefits arising from the commercial and other utilization of genetic resources with the Contracting Party providing such resources.

Similarly, the Human Genome Organisation has stated that researchers should share the benefits of their research with the research subjects who have assisted in the enterprise. $^{94}$

Some groups are particularly valuable, in that they may contribute unique genetic material. Researchers have sought out isolated populations because of their limited genetic diversity, in order to accelerate the process of research. ${ }^{95}$ For example, the discovery of the breast cancer gene BRCA-1 was achieved after a decade of sampling and testing Mormon families in Utah, who had genetic commonality and extensive genealogical records.

Hanson argues that these concerns can be addressed by informed consent. ${ }^{96}$ However, the Canavan situation suggests that greater controls are necessary to protect the interests of groups providing materials for research. ${ }^{97}$ Human sources are generally unaware of the potential for commercial gain and, even if they are aware, they are usually unsuccessful in obtaining a share of the benefits. If they contribute genetic material for altruistic reasons, such as accelerating the discovery of a diagnostic test, treatment, or cure, and a patent is subsequently obtained, they may be precluded from accessing the results of their contributions. This is because a patent owner has the right to prevent others from encroaching on the patented invention and may charge high prices for access to products or tests.

As was considered in chapter 3, the patient-based group, PXE International, set up a bank of biological material and requires any researchers wishing to access that resource to agree, before accessing the material, to share any resulting patent rights. However, it is likely that this is an exceptional situation that is only likely to arise where there is an organised group for individual contributors to join, and sufficient numbers of similarly afflicted individuals to negotiate together.

In a contract system, physicians would be required to inform a patient about the potential value of cells or tissues, in addition to the risks and benefits of removing the materials for health treatment. They might be required to advise patients to seek legal advice or register their interests with the Authority, before consenting to the use of the tissue.

\footnotetext{
${ }^{92}$ Peter Drahos “Indigenous Knowledge, Intellectual Property and Biopiracy: Is a Global BioCollecting Society the Answer?” (2001) 6 Eur Intell Prop Rev 245, 245.

${ }^{93}$ United Nations Environment Programme Convention on Biological Diversity (1992) article 15.7 $<$ http://www.biodiv.org/default.shtml > (last accessed 16 February 2005).

${ }^{94}$ Human Genome Organisation HUGO Ethics Committee Statement on Benefit Sharing (HUGO, London, 2000) <http://www.hugo-international.org/hugo > (last accessed 24 March 2004).

${ }^{95}$ Lori Andrews and Dorothy Nelkin Body Bazaar (Crown Publishers, New York, 2001) 43-4.

${ }^{96}$ Mark J Hanson "Biotechnology and Commodification within Health Care" (1999) 24 J med philos $267,280$.

${ }^{97}$ See the discussion in chapter 3 .
} 
Contractual negotiations could be burdensome for individuals and discourage contribution by people who might otherwise have been prepared to be involved in research. Most individual contributors would not recognise the potential value of their biological specimens. If they need medical treatment, they are more likely to be focussed on their condition, and would be unlikely to refuse treatment, even if they were fully informed about potential future research use of their tissues. Negotiations with individual contributors may have a deleterious effect on research, because it would add to the existing complexity arising from the need to negotiate numerous patent rights before research is able to proceed. However, legislation could provide a formula for compensation of contributors, to avoid the need for individual negotiations. The Authority could oversee the negotiation of group compensation. ${ }^{98}$

\section{GLOBALISATION}

Globalisation is an additional complicating factor when reforming patent law. The rapid dissemination of scientific knowledge and the international nature of the biotechnology industry suggest that the world community should co-ordinate regulatory policy, to minimise forum shopping and enable a rapid response to ethical and legal concerns. New Zealand is a net importer of technology, with most New Zealand patents being granted to non-residents. ${ }^{99}$

Most of the benefits of New Zealand patents flow overseas, or the benefits occur even if there were no patent system, because the overseas patent holders would apply for patents overseas and details of the inventions would be published by overseas patent offices. This suggests that the criteria should be as strict as possible. However New Zealand needs to provide adequate levels of patent protection to ensure that overseas inventions are able to be exploited here. As stated by Thurow: ${ }^{100}$

The knowledge-based economy is fundamentally transforming the role of the nation-state. Instead of being a controller of economic events within its borders, the nation-state is increasingly having to become a platform builder to attract global economic activity to locate within its borders.

New Zealand is a member of the World Intellectual Property Organisation (WIPO), which is working on a Substantive Patent Law Treaty. The aim is to harmonise substantive international patent law, dealing with such things as threshold tests for patentability. The problems of international harmonisation are formidable, in light of differing cultural and socio-political positions about matters such as the concept of human dignity and the value, role, and impact of gene patents. Additionally, existing international trade agreements, such as TRIPs, have the potential to create trade barriers for those seeking to unilaterally alter established patent rules.

Intellectual property is closely tied to the broader political goal of economic development and restrictions may prove unattractive, both politically and within

\footnotetext{
${ }^{98}$ See the discussion in chapter 8 .

${ }^{99}$ Ministry of Economic Development Review of the Patents Act 1953Stage 3: Boundaries to Patentability (Ministry of Economic Development, Wellington, 2002) $6<$ http://www.med.govt.nz> (last accessed 14 February 2004). In 2001, of a total of 4,727 patents, 4,351 were granted to nonresidents.

${ }^{100}$ Lester Thurow "Globalization: The Product of a Knowledge Based Economy” (2000) 570 Ann Am Acad Polit Soc Sci 19, 21.
} 
industry. The most influential factor is the United States' strong pro-patent policy, as much of the biotechnology industry is located there. ${ }^{101}$

Caulfield suggests that countries with modest economic influence can either move forward with patent reform, such as compulsory licensing, and accept the backlash from the global economy, or make minor revisions within existing patent rules, with little effect on commercialisation, such as applying the utility requirement more stringently. ${ }^{102}$ Alternatively, they can "work with the world community with a goal of developing an international patent policy that is more sensitive to the needs of public health care goals." 103

\section{CONCLUSIONS}

The present patent system impedes research, as patents that are overly broad may lead to excessive licensing requests. A genetic material patent only needs to identify one utility, to obtain a patent over the gene itself. The patent holder will then hold a broad patent that would cover any subsequent use of that gene for a period of 20 years. This allows the patent holder to have rights over any subsequent research, or use, of the patented genetic material.

Whatever ethical stance is taken to the patenting of life, many patents have been granted and the effects cannot readily be undone. More stringent application of the criteria for granting a patent may partially address concerns around the patenting of genetic material. However, they do not resolve the need to protect the position of the sources of the biological material, or the potential for cultural offence. Consultation is valuable, but it is of limited effectiveness, as it does not necessitate acceptance of the views expressed. ${ }^{104}$ There is a tension between the altruism required of sources and the patent system, which permits companies to enforce lucrative property claims over the outcomes from that research.

Moore ${ }^{105}$ demonstrates the inadequate protection of research subjects in the world of rapidly developing biotechnology. Although the Court was prepared to expand the law of informed consent, it did not resolve the issue of rights in inventions based on a person's tissue. Greenberg ${ }^{106}$ shows that informed consent is not a solution if the donor of the material is not receiving medical treatment, or if a patient gives consent to the collection of the research materials, without appreciation of the commercial potential.

Human sources should be able to control, and profit from, patents based on their DNA. The refusal to grant such rights undervalues their contributions to the inventive process. The effect is likely to be a loss of trust and a reluctance to be involved in research. The recognition that human sources have property rights in

\footnotetext{
101 Timothy Caulfield "Gene Patents, Human Clones, and Biotechnology Policy: The Challenges Created by Globalization" (2003) 41 Alberta L Rev 713, 719. Of the human gene patents filed between 1996 and 1999, 62 per cent were filed by organisations in the United States, 20 per cent in the European Union, and 10 per cent in Japan.

${ }^{102}$ Caulfield, above, 720.

${ }^{103}$ Caulfield, above, 720 .

${ }^{104}$ See the discussion relating to consultation with Māori in chapter 5 and consultation by national ethics committees in chapter 8.

${ }^{105}$ Moore v Regents of the University of California (1990) 51 Cal 3d 120, 168 (Cal Sup Ct).

${ }^{106}$ Greenberg and others v Miami Hospital Research Institute and others (2003) 264 F Supp 2d 1064, 1070 (SD Fla).
} 
excised tissue could increase the costs of biological research, by expanding the administrative costs, and the costs of compensation. However, that, in itself, does not justify the exploitation of human sources, by denying any rights in the tissue once a so-called "informed" consent has been given.

If the sources' property interests in their excised tissue were recognised, contractual arrangements could grant compensation in proportion to their contribution to the invention. Individuals could choose whether to negotiate on their own behalf, through a patient group or through the Human Tissue Authority.

Groups in the position of the Canavan families would gain the power to control the licensing of genetic tests, to ensure that tests are freely available. If the property was patented without consent, conversion claims would arise and the patent would be unenforceable. As stated by Dickenson: "The problem lies not with erecting fences, but with whom they enclose: not those with power, but those without."

${ }^{107}$ Donna Dickenson "Commodification of Human Tissue: Implications for Feminist and Development Ethics" (2002) 2 Developing World Bioethics 55, 63. 


\title{
Chapter 8
}

\section{FRAMEWORK}

\author{
"Every public action which is not customary either is wrong or, if it is right, it is a \\ dangerous precedent. It follows that nothing should ever be done for the first \\ time."
}

\section{INTRODUCTION}

This thesis proposes a legislative framework for the retention and use of body parts. Such regulation, in the form of prescriptive rules, is the most common response to a policy problem and the state has interests in this area if there are demonstrable harms or negative impacts on society or regulation is necessary to ensure high standards of treatment. As technology is moving faster than the development of societal views and public policy, policy gaps are constantly arising. Consequently, it is difficult for the law to provide a framework for principled decision making with respect to complex biotechnological and medical issues.

The effect of scientific development has been to present the achievable as the acceptable, and so changes to natural processes, such as reproductive technologies, have been normalised. Debates over new developments tend to arise only after reports of their invention; consequently, the law is always attempting to catch up with technologies that are already in existence. There are differing views as to how the law should respond to these challenges. One view is that regulation of genetic technology is an oxymoron, because technology is out of control. ${ }^{2}$ However, this thesis suggests the law can develop in a coherent manner if a property interest in body parts is the conceptual basis of the law combined with autonomy, informed consent and privacy.

Science is not easily presented to the public through the readily available fora, such as the media. The House of Lords observed that "society's relationship with science is in a critical phase." ${ }^{3}$ It noted that, although issues involving science are in the forefront of public attention, such interest is offset by "public unease, mistrust and occasional outright hostility." 4 This thesis has argued that such views are exacerbated by concerns about commercialisation of biotechnology.

Consequently, issues relating to biotechnology should be the subject of wide ethical debate, as they are often highly significant to an individual's world view and the decisions made have the potential to significantly affect future human progress. In recognition of this necessity, following the recommendations of the Royal Commission on Genetic Modification, the New Zealand government established the Bioethics Council. $^{5}$

\footnotetext{
${ }^{1}$ F M Cornford Microcosmographica Academica, (Bowes and Bowes, Cambridge, 1908) as referred to in Stafford Beer Decision and Control (Wiley, London, 1966) 33.

2 Julia Black "Regulation as Facilitation: Negotiating the Genetic Revolution" (1998) 61 MLR 621, 621.

${ }^{3}$ House of Lords Select Committee on Science and Technology Science and Society (HMSO, London, 2000) para 1.1 .

${ }^{4}$ House of Lords Select Committee on Science and Technology, above.

${ }^{5}$ A Ministerial advisory body to provide independent advice to Government on biotechnological issues involving significant cultural, ethical and spiritual dimensions, promote and participate in public
} 
Such matters can also be debated by way of the legislative processes, and through the decisions of the courts. Hon Michael Kirby, when referring to intellectual property and the genome stated: ${ }^{6}$

It is essential to realise that, in these fields, not to do anything is effectively to make a decision. It is to accept that science and technology ma[y] take our societies where they will.

He considered that such matters should not be left to the courts as it is preferable that Parliament should devise broad guidelines for policy. However, if legislation is not passed, the judiciary will "fill the legal gap by analogical reasoning from earlier broad principles of the common law." The modern trend favours legislation incorporating broad principles, in which much decision making is delegated to ethics committees. Kirby supports such delegation, explaining: ${ }^{8}$

\begin{abstract}
Keeping the law in a good state in a world of so many complex problems is a major challenge for global and national institutions. Indeed, it is a major challenge to democracy. The likely institutional solution, as it seems to me, will be the delegation of law-making detail to expert bodies, acting in conformity with very broad guidelines endorsed by Parliament.
\end{abstract}

Although prescriptive legislation is unsuitable in this area, because it would require frequent amendment, the need for flexibility must be balanced against arguments that public policy should not be established by unelected groups, such as ethics committees. As ethics committees are often constituted pursuant to legislation, it could be argued that this is a democratic process, but legislation should set the parameters within which such committees operate and the issues they should consider, in addition to the methods of selection of committee members. ${ }^{9}$

This chapter suggests a legislative framework in light of the defects in the present human tissue legislation discussed in chapter 2. It argues that the approach suggested is preferable to that proposed in the Human Tissue Bill (HTB), because it provides a conceptually coherent approach to the collection and use of body parts, enables remedies if the parts are misappropriated and allows source to negotiate a share in profits from inventions utilising their body parts. ${ }^{10}$ This chapter includes selected draft sections incorporating the property construct. ${ }^{11}$ It identifies the nature of the property interest and its application to deceased persons and excised parts of living persons, including living organ donation, and concludes that a Human Tissue Authority would be necessary to oversee the legislation and produce guidelines.

\title{
II PROPERTY INTEREST
}

\footnotetext{
dialogue on cultural, ethical and spiritual aspects of biotechnology, and enable public participation in the Council's activities and provide information on the cultural, ethical and spiritual aspects of biotechnology. <http://www.bioethics.org.nz> (last accessed 21 September 2006).

${ }^{6}$ Michael Kirby "Genomics and Democracy- A Global Challenge” (2003) 31 WALR 1, 1.

${ }^{7}$ Kirby, above, 18.

${ }^{8}$ Kirby, above, 18.

${ }^{9}$ As in the Human Assisted Reproductive Technology Act 2004, ss37-41.These sections provide a structure for the Advisory Committee on Assisted Reproductive Technology when developing guidelines.

${ }^{10}$ The Human Tissue Bill is discussed in chapter 2.

${ }^{11}$ This chapter does not contain an entire statute- only selected sections for demonstrative purposes.
} 
This thesis proposes that cadavers and body parts excised from living persons are property. Property in the cadaver arises at death and passes to the representative of the deceased person. The legislation, like the HTB, would exempt embryos and gametes, as they fall within the HART Act. The HTB generally excludes cell lines and the UKHTA also exempts hair and nails from the body of a living person, presumably because these are commonly discarded. Sources commonly abandon other bodily products, such as urine or tissue removed during surgery, in which case a person who obtains possession may acquire property rights. However, such products should fall within the proposed framework as they may be valuable for research. ${ }^{12}$ Accordingly, the interpretation section would include:

(1) In this Act, except as provided in subsection (2) "material from a human body" means material, which consists of or includes human cells.

(2) In this Act, references to material from a human body do not include embryos or gametes outside the human body.

(3) In this Act references to material from the human body are to material separated from a person's body whether the person was alive or dead at the time of separation.

(4) "Embryo" and "gamete" have the same meaning as in section 5 of the Human Assisted Reproductive Technology Act 2004.

(5) Except as provided for in this Act,

(a) material from a human body has the status of property

(b) the body of a dead person has the status of property

\section{NON-THERAPEUTIC USE OF TISSUE}

\section{A Living Sources}

The Code states that consumers must be informed of any proposed participation in teaching or research, including being informed whether the research requires and has received ethical approval. ${ }^{13}$ It also requires that consent to participate in research, as part of a health care procedure, must be informed consent, and must be given in writing. ${ }^{14}$ However, Right 7(10) permits unconsented research use, utilising samples that are not necessarily anonymised, with ethics committee approval. ${ }^{15}$

Parry suggests that tissue samples could be regarded as abandoned by the patient, thus res nullius and available for any legitimate purpose such as research. ${ }^{16}$ If generic consent is not sufficient to permit the future use of surplus tissue for research, then further consent to each use would be required. ${ }^{17}$ Parry argues that this would be

\footnotetext{
${ }^{12}$ As was John Moore's diseased spleen. See chapter 3. Also note the cultural significance of such materials to Māori- see chapter 5.

${ }^{13}$ Code of Health and Disability Services Consumers' Rights, Right 6 (1)(d).

${ }^{14}$ Code of Health and Disability Services Consumers' Rights, Right 7(6).

${ }^{15}$ Discussed in chapter 3.

${ }^{16}$ Bronwyn Parry "From Bodies to Technological Artefacts: To What Does the New Human Tissue Bill apply? Categorization issues and their Implications" (Draft Paper prepared for Human Tissue Conference, 2004) <http://cgkp.org.uk> (last accessed 14 May 2004).

${ }^{17}$ The Ministry of Health favours individuals being able to consent to their tissues being used for future unspecified research so long as that consent is distinct from the consent to collect the sample and any
} 
undesirable, as such consent "would be extraordinarily time consuming and expensive to obtain, have a profoundly constraining effect on research and be very trying, if not also distressing for donors. $" 18$

During the debates about the UKHTA, doctors argued that it would be impossible to take and record consents ${ }^{19}$ and that specific consent is unnecessary, as most patients are happy to have tissue used for research and teaching. ${ }^{20}$ However, if consent is easily acquired, requiring it would not impede research and would respect the rights of those who object. Alternatively, to record and respect the small number of dissents, rather than consents, may be a less cumbersome alternative.

Despite this willingness, it appears that attitudes to tissue samples are changing, as awareness of the information that might be obtained from them increases. This is demonstrated by the numbers of people requesting the return of the "Guthrie test" samples. ${ }^{21}$ If a generic consent at the time of excision is sufficient to permit any future uses, this is likely to result in a consent form with another box to "tick" by patients. They may have little knowledge of potential uses, some of which might be offensive to them. Although blanket consent is not inconsistent with the property construct, sources should be informed before making this choice, which involves more than just deciding "yes" or "no". If samples are to be used without consent, they should be anonymised. Consequently, Right 7(10) should be amended to read as follows: ${ }^{22}$

10) No body part or bodily substance removed or obtained in the course of a health care procedure may be stored, preserved, or used otherwise than

(a) with the informed consent of the consumer; or

(b) For the purposes of research that has received the approval of an ethics committee and is carried out in circumstances such that the person carrying it out is not in possession, and not likely to come into possession, of information from which the person from whose body the material has come can be identified; or

(c) For the purposes of 1 or more of the following activities, being activities that are each undertaken to assure or improve the quality of services:

(i) a professionally recognised quality assurance programme:

(ii) an external audit of services:

\footnotetext{
consent for use in specified research. Ministry of Health Guidelines on the Use of Human Tissue for Future Unspecified Research Purposes: Discussion document (Ministry of Health, Wellington, 2006) para 6.1.

${ }_{18}^{18}$ Parry, above, para 7.

${ }^{19}$ The NHS processes almost 150 million tissue specimens from living patients each year. One study found that 99 per cent of 3,000 patients gave consent for their tissue to be used for research. Kirsty Scott "The Tissue Issue" (29 April 2004) The Guardian London < http://www.guardian.co.uk/life> (last accessed 14 June 2004).

${ }^{20}$ Scott, above.

${ }_{21}$ As discussed in chapter 3 .

${ }^{22}$ The amendment is shown in bold.
} 
The Protection of Personal and Property Rights Act 1988 provides a protective framework for incompetent adults. ${ }^{23}$ If excised body parts are the property of the source, this would widen the protection available to persons who wholly or partly lack the ability to manage their property affairs. ${ }^{24}$ If the source had not created an enduring power of attorney prior to incompetence arising, the Court would appoint a property manager, whose role is governed by the Court order. The property does not vest in the manager, but the manager is entitled to possession of it and can make appropriate decisions in accordance with the terms of the order. ${ }^{25}$

The Code provides that if the consumer is not competent to give consent and there is no one else entitled to make the choice on the consumer's behalf, Rights 7(4) and 9 apply so that:

- The provider may collect and use tissue where it is in the best interests of the consumer; and

- Reasonable steps must be taken to ascertain the views of the consumer; and

- If the consumer's views have been ascertained, the provider must assess whether the provision of services is inconsistent with the informed choice the consumer would make if competent; or

- If it is not possible to ascertain the views of the consumer, the provider must take into account the views of other suitable persons who are interested in the welfare of the consumer and who are available to provide such advice.

The Code is based on the concept that consumers have the right to complain, but it is unlikely that many complaints would be received from persons with reduced capacity. Decisions that are not for the medical benefit of the incompetent person, such as involvement in non-therapeutic research, or organ donation, should continue to be made by the court or by the Authority, especially if family members, or other "suitable" persons, have conflicts of interests. ${ }^{26}$ The present emphasis on only giving approval to such procedures in exceptional circumstances should remain, to avoid results such as that in Re Y (Mental Incapacity: Bone Marrow Transplant). ${ }^{27}$

Consequently, the use of the body parts of living incompetent adults should continue to fall within the Code and the Protection of Personal and Property Rights Act 1988. Living organ donation should be overseen by the Family Court or the

\footnotetext{
${ }^{23}$ This Act is proposed to be amended by the Protection of Personal and Property Rights Amendment Bill. See chapter 6 for consideration of the roles of the welfare guardian and the property manager.

${ }^{24}$ Protection of Personal and Property Rights Act 1988, s 25.

${ }^{25}$ Protection of Personal and Property Rights Act 1988, ss 35(2) and 36. Re Smith [1927] GLR 274, where Skerrett CJ said that "the management of the patient's affairs and the administration of his property is undertaken by the Public Trustee in the interests of the patient and not for the benefit of his creditors, his presumptive next of kin, or his heirs. The primary consideration must always be the interests of the patient, and care must be taken to ensure that that he will be provided in his helpless condition with sufficient maintenance".

${ }^{26}$ See the suggested functions of the Human Tissue Authority later in this chapter.

${ }^{27}$ Re Y (Mental Incapacity: Bone Marrow Transplant) [1996] 2 FLR 787; [1997] 2 WLR 556 (Fam D) Connell J. This case is discussed in chapter 6.
} 
Authority. The property interest in the cadaver of an incompetent adult would pass to the person highest on the priority list, unless the incompetent person had appointed a representative prior to the incompetence arising. ${ }^{28}$

\section{$2 \quad$ Children and consent}

Under the proposed framework, parents or guardians would be the representatives for incompetent children. Gillick competent children could give consent and appoint representatives, or else the priority list would apply.

(1) Subject to subsection (2), if the child concerned is alive and is competent to give consent "appropriate consent" means the child's consent.

(2) Where-

(a) the child concerned is alive, and

(b) either the child is not competent to deal with the issue of consent in relation to the activity or though competent to deal with that issue fails to do so, "appropriate consent" means the consent of a parent or guardian of the child

(3) Where-

(a) the child concerned has died, and

(b) prior to death the child was competent to give consent

"appropriate consent" means the child's consent in writing which was in force prior to the death of the child.

(4) Consent in writing for the purposes of subsection (3) is only valid if-

(a) it was signed by the child concerned in the presence of at least one witness who attested the signature, or

(b) it was signed at the direction of the child concerned, in the child's presence and in the presence of at least one witness who attested the signature.

(5) Where the child concerned has died and immediately prior to death either the child was not competent to deal with the issue of consent in relation to the activity or though competent to deal with that issue failed to do so,

“appropriate consent” means

(i) the consent of a parent or guardian of the child, or

\footnotetext{
${ }^{28}$ See the jurisdiction of the Human Tissue Authority later in this chapter.
} 


\section{Consent may be revoked at any time prior to death by the same means as the consent may be given.}

If parents or guardians consent to the use of living children's tissues for either specified or unspecified future research, ${ }^{29}$ it is unclear whether the children may withdraw that consent once they are competent. The Operational Standard affirms the right to withdraw consent. ${ }^{30}$ The Ministry of Health states that this, together with the Code's emphasis on consent, results in an expectation that those whose tissues were donated for research purposes should have the right to withdraw that consent, once competent. $^{31}$

If the child can withdraw, there are the following consequences:

- $\quad$ Tissues could not be absolutely anonymised until the child reached competence and gave consent, or had died. The tissues could not be included in studies necessitating anonymised or de-linked samples;

- $\quad$ Processes would be needed to ensure the child was aware of the need to give or withdraw consent, or to ensure that the institution approached the child for re-consent; ${ }^{32}$

- $\quad$ Researchers could be excluded from international collaborations in which samples are sent overseas.

If the child cannot withdraw once competent, the proxy consent would remain in force indefinitely.

The welfare and best interests of the child are the first and paramount consideration in proceedings relating to the administration of property belonging to a child. ${ }^{33}$ Consequently, if the research relates to a condition affecting the child and could lead to a treatment, it is reasonable to permit parents or guardians to consent to future unspecified research use of an incompetent child's tissues, without a need for the child to re-consent once competent. However, if the research has no potential benefit for the particular child, the ethics committee must weigh the welfare of the child against the public good.

The Operational Standard provides that an ethics committee may permit research without consent where it is not practicable to seek consent from an individual and a potential public good can be weighed against the right of an individual to give

\footnotetext{
${ }^{29}$ See the discussion of the Canavan children and PXE International in chapter 3.

30 Ministry of Health Operational Standard for Ethics Committees (Ministry of Health, Wellington, 2002) para 29.

${ }^{31}$ Ministry of Health Guidelines on the Use of Human Tissue for Future Unspecified Research Purposes: Discussion document (Ministry of Health, Wellington, 2006) para 4.6.

${ }^{32}$ If the institution were required to re-contact the child it would need current contact information.

${ }^{33}$ Care of Children Act 2004, s 14 (1).
} 
consent. ${ }^{34}$ The Human Tissue Authority should oversee practices and formulate guidelines with respect to incompetent children. ${ }^{35}$

\section{B Powers to Dispense with the Need for Consent \\ $1 \quad$ Public interest}

There are limited circumstances in which the public interest might outweigh the individual's property interest and unconsented use would be justifiable without anonymisation. Such provisions are not incompatible with the framework, as compulsory acquisition of private property in the public interest occurs in other contexts. ${ }^{36}$ In exceptional cases, such as where a person has died of a new virus and a representative cannot be found to give consent to take tissue for testing, approval by the Authority would be required.

(1) Where no refusal of consent has been made by the source prior to death and no representative can be found to give consent, the Human Tissue Authority may determine that appropriate consent exists for an activity consisting of-

(a) the storage of the body of a deceased person for the purpose of research in connection with disorders, or the functioning, of the human body,

(b) the use of the body of a deceased person for that purpose,

(c) the removal from the body of a deceased person, for use for that purpose, of any relevant material of which the body consists or which it contains,

(d) the storage for that purpose of any relevant material which has come from a human body,

(e) the use for that purpose of any relevant material which has come from a human body.

\section{$2 \quad$ Third parties}

On occasion, a source may be untraceable, but not known to be dead or incompetent and use of their stored material is necessary to obtain scientific or medical information in the interests of another person. This might arise if analysis of a sample is necessary to treat a relative, but no prior decision had been made by the untraceable source. The Authority should be able to give the required consent, on the basis either that the human source has abandoned the sample, or that the public interest justifies such a power.

(1) If the Human Tissue Authority is satisfied:

(a) that relevant material has come from the body of a living person

("the source"), and

(b) it is not reasonably possible to trace the source, and

\footnotetext{
${ }^{34}$ Ministry of Health Operational Standard for Ethics Committees (Ministry of Health, Wellington, 2002) para 35.

${ }^{35}$ See the jurisdiction of the Authority, below.

${ }^{36}$ Such as under the Public Works Act 1981.
} 
(c) it is desirable in the interests of another person (including a future person) that the material be used for the purpose of obtaining scientific or medical information about the source, and

(d) there is no reason to believe-

(i) that the source has died,

(ii) that the source has refused to consent to the use of the material for that purpose, or

(iii) that the source lacks capacity to consent to the use of the material for that purpose,

it may direct that subsection (2) apply to the material for the benefit of the other person.

(2) Where material is the subject of a direction under subsection (1) the source's consent is deemed for the use of the material for the purpose of obtaining scientific or medical information about the source which may be relevant to the person for whose benefit the direction is given.

\section{Research Use of Existing Holdings}

Researchers argue that to require informed consent for new research utilising previously collected samples will usually make the research unfeasible and would lessen the scientific quality of large databases. However, abandoning the consent requirement would violate the subject's interest in controlling medical records and tissues. As Greely states: "One can imagine an unconsenting subject of such research exploding with: "It's my blood, damn it. How can they use it without my permission?"37

One argument for unconsented research on extant samples is the notion of community consent. If the community is well-informed and polls indicate widespread support for research, then it is fair to presume consent, with ethics committee approval providing adequate controls. This is a dubious argument in light of the frequent lack of scientific knowledge and the limitations of polls as a form of public engagement. If most people approve of the research use of their samples, then unconsented use is not justified, as consent should be readily available. In light of the wide and increasing variety of potential uses for such material and the potential commercial ramifications, it is inadequate to delegate the decision-making solely to ethics committees. ${ }^{38}$ In particular, once the material becomes a commodity, exploited by a private corporation for commercial profit, the context differs substantially from traditional healthcare research.

As was discussed with respect to the "Guthrie" samples, ${ }^{39}$ use of samples without consent risks the integrity of screening programmes. To ensure minimum intrusion into personal interests and autonomy, consent should be sought if the

\footnotetext{
${ }^{37}$ Henry T Greely "Breaking the Stalemate: A Prospective Regulatory Framework for Unforeseen Research Uses of Human Tissue Samples and Health Information” (1999) 34 Wake Forest L Rev 737, 758.

${ }^{38}$ As in Code of Health and Disability Services Consumers' Rights, Right 7(10).

${ }^{39}$ Discussed in chapter 3.
} 
sources or representatives are able to be traced, as the human source, personal representative of a deceased source or family members may have ongoing interests in the uses of samples, including cultural concerns. ${ }^{40}$

Only samples collected many years ago, where there is no potential harm to sources and the research is not sensitive, might justifiably be used for public health research without consent. The samples should be anonymised and ethics committee approval obtained. This could be justified on the basis that the source's failure to request the return of the samples amounts to abandonment of them, or that this is a situation where public policy overrides the property interest of the human source.

\section{Existing holdings}

(1) In this section, "existing holding” means:

(a) the body of a deceased person, or

(b) relevant material which has come from a human body,

held, immediately before the day on which this section comes into force.

(2) No existing holding may be stored, preserved, or used otherwise than:

(a) with the informed consent of the source or the representative of a dead source; or

(b) If the Human Tissue Authority is satisfied that it is not reasonably practicable to trace the source or the source's representative it may direct that the source's consent is deemed for the purposes of research in connection with disorders, or the functioning, of the human body that has received the approval of an ethics committee and is carried out in circumstances such that the person carrying it out is not in possession, and not likely to come into possession, of information from which the person from whose body the material has come can be identified.

\section{Future Unspecified Research}

The term "biobank" refers to collections of various kinds of genetic samples and health information, such as the heel prick sample collection. ${ }^{41}$ Recently, biobanks have been established for use in prospective research, based on informed consent being given by the sources for broadly defined future research purposes. ${ }^{42}$

Greely proposes a framework for the collection of research materials for future unspecified research, requiring "permission" for research use, arguing that it is not possible to give informed consent to future, as yet unknown, research purposes as it is not possible to be fully informed. ${ }^{43} \mathrm{He}$ also suggests extra protections,

\footnotetext{
${ }^{40}$ Discussed in chapter 5.

${ }^{41}$ See the discussion in chapter 3 .

${ }^{42}$ Such as the UK Biobank.

${ }^{43}$ Greely, above, 764.
} 
implemented through additional disclosures, or through ethics committee considerations, in an effort to compensate for the research subject's own inability to impose conditions, or to refuse to participate after the initial permission. The result is a compromise. Some data and samples will not be available for research, because the source refuses to grant unrestricted research permission. However, some will be used for research under such a general permission, although the sources may have refused consent if they were aware of the actual research proposal. ${ }^{44}$

This thesis argues that sources should be able to authorise the use of their tissues for future unspecified research, so long as they intend to unconditionally transfer their interests in the material to the biobank. A person can agree to transfer a property interest absolutely, without any knowledge or control of the future use of the item.

However, in most cases where biological samples are provided for medical tests, there is no agreement to retention after the primary purpose is completed or to transfer ownership to a biobank. The samples are held akin to a bailment or trust, with the holder only having the right to use them for the agreed testing or screening. Consequently, before providing samples, human sources must decide whether they are agreeing to future secondary use of them. If so, is the agreement unconditional, or subject to conditions?

Sources should be advised of the potential for samples to be used for future, as yet undetermined research, and, if they refuse consent to research use, have that refusal recorded and respected. Commercial interests and options concerning recontact should be disclosed and agreement reached. An example where re-contact would be relevant is if the research discovered clinically significant information about the source. Sources might wish to limit the types of research, or exclude certain types of research. There might be a time limit on the use of the materials, as many people would be concerned about their body parts being used indefinitely for, as yet unimagined, purposes or the infinite replication of cell lines. The agreement would determine the ultimate disposition of the samples, such as destruction, return to the source, or agreement for ongoing use, either with or without conditions.

In order to avoid situations such as in Catalona, ${ }^{45}$ the ownership of the samples must be explicitly agreed, together with any rights to withdraw from the research. Unless the samples are unconditionally transferred, sources should be able to withdraw their biological material from the research database at any time. This is required pursuant to the UNESCO Universal Declaration on Bioethics and Human Rights, which states that consent for scientific research should include the modalities for withdrawal of consent and that the consent may be withdrawn at any time and for any reason, without disadvantage or prejudice. Some exceptions are permitted, but the general thrust is that, despite the potential logistical difficulties, consent may be withdrawn. ${ }^{46}$

\footnotetext{
${ }^{44}$ This is similar to the proposals of the Ministry of Health, although they refer to "consent" rather than "permission". Ministry of Health Guidelines on the Use of Human Tissue for Future Unspecified Research Purposes: Discussion document (Ministry of Health, Wellington, 2006) para 6.1.

${ }^{45}$ Washington University v Catalona (2006) US Dist LEXIS 22969 Limbaugh J. See the discussion in chapter 3.

${ }^{46}$ UNESCO Universal Declaration on Bioethics and Human Rights Paris 24 June 2005, Article 6 (b).
} 
Ethics committees would still need to consider research proposals, to ensure they provide for appropriate information and choices to be given to the sources. Additionally, they have a role to ensure that the research as a whole is ethical, as research potentially affects the wider community and it may be sensitive because of its nature, or because of its impact on particular groups.

Although such proposals might be criticised in light of the record keeping required, they are generally in line with international trends. ${ }^{47}$ In New Zealand, guidelines are proposed to deal with consent for the retention of human tissue in biobanks for use in future unspecified research. ${ }^{48}$ They propose that individuals be able to consent to their tissues being used for future unspecified research and that consent forms should allow the imposition of restrictions and conditions. ${ }^{49}$

\section{E Anonymisation}

Anonymisation of data is commonly considered to be sufficient protection of the interests and rights of the sources of the tissue, as they cannot be harmed by information or samples that cannot be linked to them.

Greely states 50

Anonymity is not such a panacea, however. For one thing, as the stored tissue samples controversy shows, the term is ambiguous. Are data or samples anonymous if the researcher's copy contains no identifying information, even if a key to identities exists somewhere? Are data or samples anonymous if the only key is buried in computer software and not easily accessible to any human? Are data or samples anonymous only if no possible link can be made between them and the identity of their source?

The information itself can be identifying, as computerised databases can link information. Researchers could restrict the amount of data accessed, but every characteristic omitted from the database is one more factor, or confounding variable, that cannot be analysed.

Absolute anonymity may not necessarily protect the donor's interests, as people may be offended on ideological or religious grounds if their records or tissue samples are used for some types of research, even if completely anonymised. The

\footnotetext{
${ }^{47}$ Council for International Organisations of Medical Sciences and World Health Organization The International Ethical Guidelines for Biomedical Research Involving Human Subjects (CIOMS, Geneva, 2002) Commentary on Guideline 4: Waiver of the consent requirement; National Health Medical Research Council, Australian Research Council and Australian Vice-Chancellors' Committee Draft of the National Statement on Ethical Conduct in Human Research: Second consultation draft (2006) <http://www.nhmrc.gov.au> (last accessed 14 May 2006); Medical Research Council Operational and Ethical Guidelines: Human Tissue and Biological Samples for Use in Research Clarification Following Passage of the Human Tissue Act 2004 (MRC, London, 2005) para 4.4; National Bioethics Advisory Commission Ethical and Policy Issues in Research Involving Human Participants (National Advisory Commission, Maryland, 2001) Recommendation 8.

${ }^{48}$ Ministry of Health Guidelines on the Use of Human Tissue for Future Unspecified Research Purposes: Discussion Document (Ministry of Health, Wellington, 2006).

${ }^{49}$ Ministry of Health, above, section 6.

${ }^{50}$ Henry T Greely "Breaking the Stalemate: A Prospective Regulatory Framework for Unforeseen Research Uses of Human Tissue Samples and Health Information" (1999) 34 Wake Forest L Rev 737, 759
} 
harm arises from the use, not from knowledge of the use, or identification of the source. $^{51}$

If absolute anonymity exists, no additional information can be linked to the samples, beyond that available at the time of unlinking. If it is later discovered that additional information is essential to interpret the data or the samples, they become useless. If the required additional information relates to matters specific to the human source, such as response to treatment, adverse reaction, cure, or death, it is not possible to seek consent to link the data to the patient's existing records or samples. Additionally, if analysis of unlinked data or samples results in information of great importance to the health status of the human source, that information cannot be communicated to the person.

However, despite these issues, this thesis proposes that if samples are used for unconsented research, anonymisation should be required, as it reduces the risk of harm to the source. ${ }^{52}$

\section{DEAD BODIES}

This section outlines the proposals for both therapeutic and non-therapeutic use of cadavers. It argues that the suggested framework id preferable to that proposed in the Human Tissue Bill. ${ }^{53}$ It provides that the property interest in the body would arise at death, then pass to the representative. The issues to be covered in the legislation would include:

\section{A Appointment of Representative}

The role of the representative would be to carry out the wishes of the deceased, where these were known. ${ }^{54}$ Competent living persons could choose any person or persons to be their representative/s after their death. If two or more persons are appointed in relation to the same activity, they would act jointly and severally unless the appointment provides that they are appointed to act jointly. That person could be the same person as the executor in the donor's will, or any other competent person. In light of the potentially distressing and contentious decisions to be made, the framework specifies a minimum age of 18 years for the representative.

An appointment could be general or limited to consent in relation to one or more activities, as specified in the appointment. For example, the person may wish to limit the power to consent to organ donation only and not research use of the cadaver.

The appointment could be made orally or in writing. An oral appointment would only be valid if made in the presence of two witnesses, not being the representative or a spouse of the representative. A written appointment would be required to be signed by the appointer in the presence of at least one witness who attests the signature or be contained in a will. An appointment of a representative

\footnotetext{
${ }^{51}$ See the discussion of whakapapa in chapter 5.

${ }_{53}^{52}$ See the proposed amendment to Right 7(10) above.

${ }^{53}$ See the discussion in chapter 2.

${ }^{54}$ As contrasted with the Human Tissue Bill where there is no such requirement that the nominee follow the instructions of the deceased. See chapter 2 .
} 
could be revoked at any time prior to the death of the source and a person appointed as representative who did not wish to act could renounce the appointment. ${ }^{55}$

(1) A competent person "the appointer" may appoint one or more persons to be the representative of the appointer in all dealings with the interests in the appointer's body or body parts after the appointer's death including giving consent to any use of the body after death.

(2) An appointment under this section may be general or limited to consent in relation to one or more activities as may be specified in the appointment.

(3) An appointment under this section may be made orally or in writing.

(4) An oral appointment under this section is only valid if made in the presence of at least two witnesses present at the same time neither of whom may be the representative or a spouse or partner of the representative.

(5) A written appointment under this section is only valid if-

(a) it is signed by the appointer in the presence of at least one witness who attests the signature and who is not the representative or a spouse or partner of the representative; or

(b) it is signed at the direction of the appointer, in the presence of the appointer and in the presence of at least one witness who attests the signature and who is not the representative or a spouse or partner of the representative; or

(c) it is contained in a will of the appointer, being a will which is made in accordance with the requirements of section 9 of the Wills Act 1837.

(6) The appointer may revoke an appointment under this section at any time.

(7) Where an appointer appoints two or more representatives under this section in relation to the same activity, they are regarded as appointed to act jointly and severally unless the appointment provides that they are appointed to act jointly.

(8) Subsections (3) to (5) apply to the revocation of an appointment under this section

(9) A representative may renounce the appointment at any time after the death of the appointer.

(10) A representative may not act under an appointment unless the representative is of or over the age of 18 years.

B Title

\footnotetext{
${ }^{55}$ The recommended procedure would be that a copy of the appointment would be given to the proposed representative-see below.
} 
At death, title to the cadaver will pass to the representative, who must put into effect the expressed wishes of the deceased. ${ }^{56}$

(1) Immediately upon the death of the appointer, all legal interests in the body of the appointer vest in the representative.

(2) The title of the representative relates back to and is deemed to have arisen immediately upon the death of the appointer.

\section{Information to be Provided at the Time of Appointment}

Unlike the HTB, this framework considers that the wishes of the previously living person are of utmost importance, which necessitates that they have sufficient information about alternatives to make informed decisions. In addition to the general effect of the document, the source must be advised that the appointment may either be general, or limited to specified uses. The source should be given an opportunity to indicate any conditions on the type of use of the cadaver. It should be made clear whether the source intends to overrule the opinions of relatives or whether the document is merely an expression of lack of objection, with the final decision to be made by the representative either with or without consultation with family. This could be achieved by prescribing the form of appointment, incorporating the options. ${ }^{57}$ The form should recommend that a copy be given to the representative, a copy retained with the source's papers ${ }^{58}$ and that the appointer discuss the appointment with the proposed representative.

(1) Subject to the provisions of this section, an appointment of a representative will be effective if the instrument that creates the power is in a form set out in Schedule 1 to this Act.

(2) An appointment of a representative has effect notwithstanding that it is in a form different from a form set out in Schedule 1 to this Act, if, but only if the differences are immaterial.

\section{Point at which Appointment is Effective}

The appointment will be effective at the point of death, which is an irreversible cessation of all of a person's brain functions, assessed by ordinary standards of current medical practice. ${ }^{59}$ So long as the appointment was made as above it will be immediately effective, with no requirement to obtain authorisation, such as probate.

\section{E Duties of Representative}

\footnotetext{
${ }^{56}$ See the discussion in chapter 2.

${ }^{57}$ Similar to the forms specified in Protection of Personal and Property Rights Act 1988, Schedule 3.

${ }^{58}$ See below for consideration of the establishment of a national register of appointments.

${ }^{59}$ See the discussion in chapter 4. Note that the Human Tissue Bill contains no definition of death, although clause 50 provides that the qualified person collecting tissue must be satisfied that life is extinct.
} 
The representative would be required to carry out the wishes of the deceased relating to the use of the body or, in the absence of any expressed wishes, would have the power to make the decision. This should apply in the same manner to the whole body, parts of the body such as organs, or tissue samples. For the sake of consistency, the Administration Act 1969 should be amended to state that the representative is responsible for the ultimate disposition of the body, rather than the administrator of the estate and that the representative must comply with funeral directions in the will, so long as the estate has sufficient funds.

\section{F Priority List}

The legislation should contain a priority list of persons who could act as representative, in the absence of an express appointment or if the representative was unavailable. The executor(s) named in the will ${ }^{60}$ or the administrator of an intestate estate should deal with all property of the deceased. However, as the delay in obtaining a grant of administration would limit the use of organs, the priority list would apply until the grant; thereafter the administrator would assume the ongoing role as representative. The hospital would be entitled to seek consent from the person appearing to be qualified under the list and would not be liable if acting in good faith.

If there was more than one person of the same priority, the consent of any would be valid, even if other persons on the same priority level disagreed. The representative would be able to consent to any use of the cadaver.

(1) The qualifying relationships for the purposes of this Act are ranked in the following order:

(a) executor named in the will of the deceased;

(b) administrator as defined in section 2(1) of the Administration Act 1969.

(2) In the case of a person who died without having named an executor, qualifying relationships prior to a grant of administration in accordance with subsection (1)(b) shall be ranked in the following order:
(a) spouse;
(b) parent or guardian;
(c) child;
(d) sibling;
(e) grandparent;
(f) grandchild;
(g) niece or nephew;
(h) step parent;
(i) half-sibling;
(j) friend of longstanding.

(3) A person on the priority list may not act as representative unless that person is of or over the age of 18 years.

\footnotetext{
${ }^{60}$ Note that if the will cannot be located in time, the hospital will be entitled to obtain consent from the next person on the list without liability, so long as it acts in good faith.
} 
(4) Spouse or partner includes husband or wife, civil union partner and persons who live in a relationship as defined in section 2D of the Property (Relationships) Act 1976.

(5) Consent should be obtained from the person whose relationship to the person concerned is accorded the highest ranking in accordance with subsections (1)(2) and (4).

(6) If the relationship of two or more persons to the person concerned is accorded equal highest ranking in accordance with subsections (1)(2) and (4), it is sufficient to obtain the consent of any one of them.

(7) If it is not reasonably practicable to communicate with the person whose relationship to the person concerned is accorded the highest ranking in accordance with subsections (1),(2) and (4) it is sufficient to obtain the consent of the person with the next highest ranking.

\section{G Consent}

The representative could agree to transfer the whole cadaver to researchers or only transfer organs intended for transplantation to a hospital or recipient. If the deceased had so instructed, the representative might retain ownership of the cadaver but allow researchers or others to have possession of it under specified conditions. Consent to use the body would be as follows:

- If the deceased had, prior to death, consented to the particular use, or declined to consent to it, ${ }^{61}$ that decision will apply; ${ }^{62}$

- If the deceased had appointed a representative to deal with the issue of consent after death in relation to the use in question, the representative may consent; or

- If neither applies, an executor named in the deceased's will may consent, with no requirement to first obtain probate of the will;

- If the deceased died intestate or the will did not appoint an executor, the person highest on the priority list will act as representative until an administrator obtains a grant of administration. Thereafter, the administrator may consent.

- If the appointed representative is unavailable to give consent, the priority list will apply;

- If it is not reasonably practicable to communicate with the representative or the person highest on the priority list within the time in which it is possible to use the body parts, that person will be treated as though he or she was not able to give consent and the next person on the priority list will give consent.

(1) Where the appointer has died, “appropriate consent” means-

\footnotetext{
${ }^{61}$ Note that the Human tissue bill does not refer to refusal of consent, whereas this thesis argues that both consent and dissent should be respected.

${ }^{62}$ Health and Disability Commissioner's Code of Health and Disability Services Consumers' Rights Regulation 1996 Right7(6) consent is only required to be in writing if it relates to research, the procedure is experimental, the consumer will be under general anaesthetic; or there is a significant risk of adverse effects.
} 
(a) if a decision of the appointer whether or not to consent to the activity, as required by the Health and Disability Commissioner's Code of Health and Disability Services Consumers' Rights Regulation 1996 was in force immediately before the appointer died, the appointer's consent;

(b) if-

(i) paragraph (a) does not apply, and

(ii) the appointer has appointed a representative or representatives to take the legal interest in the body after the death of the appointer, the representative's consent;

(c) if-

(i) the representative was, prior to the death of the appointer, made aware of the appointer's views, the representative must consent only to actions that the representative believes, on reasonable grounds, are consistent with the wishes of the appointer; or

(ii) the views of the appointer are unknown the representative may give a valid consent;

(d) if neither paragraph (a) nor paragraph (b) applies, the consent of a person who stood first in a qualifying relationship to the appointer immediately before the appointer died.

(2) Where the appointer has appointed a representative or representatives the appointment must be disregarded for the purposes of subsection (1) if no one is able to give consent under it.

(3) If it is not reasonably practicable to communicate with a person appointed as representative within the time available in order for the activity to be carried out the appointment must be disregarded for the purposes of subsection (1).

\section{H Preservation of the Body}

It is necessary to take immediate steps following death to ensure the body is preserved in a suitable condition for organ harvest. The institution holding the body should be authorised to take the steps necessary to preserve the body for that purpose. This authority would cease to apply once it has been established that consent has not, and will not, be given. The institution will be able to proceed with organ harvest, without risk of liability, if the deceased, the representative or a person appearing to be the highest on the priority list has given consent.

(1) Where a body is lying in a hospital, or other institution and a part of that body is or may be suitable for use for transplantation, it is lawful for the person having the control and management of the institution-

(a) to take steps for the purpose of preserving the part for use for transplantation, and

(b) to retain the body for that purpose.

(2) Authority under subsection (1)(a) extends only- 
(a) to the taking of the minimum steps necessary for the purpose mentioned in that provision, and

(b) to the use of the least invasive procedure.

(3) Authority under subsection (1) ceases to apply once it has been established that consent making removal of the part for transplantation lawful has not been, and will not be, given.

(4) The person having the control and management of the institution may arrange for the removal and use of any part from the body if that person, having made such reasonable inquiry as may be practicable, believes in good faith that appropriate consent has been given.

\section{Sanctions for Breach}

Under the proposed scheme, a representative will have the power to grant possessory rights in the body parts to the hospital or researcher, subject to any conditions. Once organs have been transplanted into recipients they become reintegrated into those persons' bodies and no longer the subject of property rights. Consequently, if the hospital misused the organs or parts there would be no ability to recover them from the recipient, but the representative could bring an action in conversion against the hospital. ${ }^{63}$ Additionally, such misappropriation would be an offence, the penalty including the forfeiture of any profits, for example, from a patented invention. It would be the researcher, doctor or hospital who would have civil and criminal liability, rather than recipients of organs, although it would be a defence if they acted in good faith, believing on reasonable grounds that the required consents had been given.

Civil liability would arise as a consequence of the provision that cadavers and excised body parts are property, thus potentially allowing civil claims such as conversion if, for example, a kidney donated to one recipient was transplanted into another person. ${ }^{64}$

(1) A person commits an offence if, without appropriate consent, that person does an activity that requires consent under this Act unless that person reasonably believes-

(a) that the person does the activity with appropriate consent, or

(b) that what the person does is not an activity which requires consent.

A person guilty of an offence under this section is liable-

(a) on summary conviction to a fine not exceeding the statutory maximum;

(b) on conviction on indictment-

(i) to imprisonment for a term not exceeding 3 years, or

(ii) to a fine, or

\footnotetext{
${ }^{63}$ The proposed legislation has not included the right to take civil action as this would arise naturally from the existence of the property interest.

${ }^{64}$ Note that this ability to bring civil actions is a major advantage from the framework. The Human Tissue Bill provides for criminal liability only.See the discussion in chapter 2 of Colavito v New York Organ Donor Network Inc (2006) 438 F 3d 214 (US App) Sack J.
} 
(iii) to the forfeiture of any profits made as a consequence of the activity or

(iii) to each of the above

(3) Subject to subsection (1), a person commits an offence if that person

(a) uses donated material for a purpose which is not a qualifying purpose, or

(b) stores donated material for use for a purpose which is not a qualifying purpose.

(4) Subsection (3) does not apply where the person reasonably believes that what the person uses, or stores, is not donated material.

(5) In subsection (3), references to a qualifying purpose are to-

(a) Anatomical examination,

(b) Determining the cause of death,

(c) Medical diagnosis or treatment,

(d) Establishing after a person's death the efficacy of any drug or other treatment administered to that person,

(e) Obtaining scientific or medical information about a living or deceased person which may be relevant to any other person (including a future person),

(f) Public display,

(g) Research in connection with disorders, or the functioning, of the human body,

(h)Transplantation,

(i) Decent disposal.

(6) In this section, references to donated material are to-

(a) the body of a deceased person, or

(b) material which has come from a human body

\section{ORGAN TRANSPLANTATION}

The current proposals for legislation in New Zealand are generally directed towards increasing the rate of organ donation, especially from deceased donors. As was considered in chapter 2, the shortage of organs in New Zealand appears to relate more to a low number of intensive care beds together with a lack of suitable donors, than to refusals by family members. Proposals to increase the donation rate were considered and it was concluded that presumed consent, required decision and required request would not provide a satisfactory solution to the current conceptual and practical problems.

\section{A Enforcement of the Wishes of the Deceased}

The framework proposed in this thesis would result in the wishes of the deceased justifiably "trumping" opposition by relatives, as would the HTB, although it would also allow relatives to consent even if this was contrary to the wishes of the deceased. 
The proposed framework is conceptually sound as there is no proxy consent power exercisable in respect of competent living adults, and so, no basis for allowing family members to overrule the expressed wish of the deceased. A person can delegate the power to deal with other property to another, by way of appointment of a power of attorney, but this power is not assumed merely because of the existence of a relationship. The discussion document recommended that the consent to donate should apply despite opposition from relatives, if: ${ }^{65}$

- $\quad$ there is support from the general public and health practitioners;

- $\quad$ the decision made by the living person was fully informed; ${ }^{66}$

- the recorded wish of the deceased was current at the time of death.

It suggested that this approach might result in a lower rate of donation than at present, because around 43 per cent of people who hold a driver's licence have indicated a wish to be a donor, whereas in an audit of intensive care units 55 per cent of families consented to donation. However, that assumes that people who take no action when they obtain their licences are refusing consent. They may not have considered the matter, but later make a decision and advise their families of their decision. This is suggested by the 7 per cent of people who change from "no" to "yes" when renewing their drivers' licences. ${ }^{67}$

The framework suggested in this thesis would require the representative to carry out the wishes of the deceased, irrespective of the family's opinions. A family member would often be chosen to be the representative, but in any event, the family would not be able to overrule the decision of the representative. This is similar to the approach suggested in the Human Tissue (Organ Donation) Amendment Bill 2006, ${ }^{68}$ although the HTB makes the families' views paramount. ${ }^{69}$

\section{B Person Lawfully in Possession}

Under the Human Tissue Act 1964, the "person lawfully in possession of the body" has the discretion to authorise the use of the body, after first ensuring that an inquest or coronial post mortem is not required. ${ }^{70}$ While the authority of the person lawfully in possession of the body ensures that responsibility for ensuring compliance with the statute rests on an identified person, this legal construct appears incongruous in a scheme based on the concept of donation. ${ }^{71}$ It has however been repeated in the Human Tissue Bill, with provision for a "responsible person" being the "person lawfully in possession of the body". 72

As the representative would be responsible for carrying out the expressed wishes of the deceased, the notion of a person lawfully in possession would be unnecessary. However, steps would be necessary to ensure that the body was

\footnotetext{
${ }^{65}$ Ministry of Health, above.

${ }^{66}$ See chapter 3.

${ }^{67}$ Ministry of Health, above, 67.

${ }^{68}$ A Member's Bill introduced by Dr Jackie Blue on 22 March 2006. New Zealand Parliamentary

Library Bills Digest No 1350.

${ }^{69}$ See the discussion in chapter 2 .

${ }^{70}$ Human Tissue Act 1964, s 3.

${ }^{71}$ P Matthews "Whose Body? People as Property" (1983) 36 CLP 193, 228.

${ }^{72}$ Human Tissue Bill, clause 8(1).
} 
preserved while the person with decision-making authority was identified. ${ }^{73}$ The institution or hospital would be able to harvest organs, if it reasonably appeared that consent had been given.

Consent to organ donation must be given promptly after death and it has been suggested this would be facilitated by establishing an organ donor register. ${ }^{74}$ The HTB does not prevent information such as consents being recorded in the register, but effective consent does necessarily have to be recorded in the register. ${ }^{75}$ It is unclear whether refusals can be recorded. ${ }^{76}$ There are difficulties arising from a register: ${ }^{77}$

- $\quad$ it is difficult to justify the cost given the small number of potential donors ${ }^{78}$ and the limited potential for a register to increase donation rates;

- donor rates may drop in the short term as the absence of an entry on the register may be taken as an indication that the person did not wish to donate;

- there is scant evidence from international literature that registers improve the donation rate;

- $\quad$ medical professionals are likely to continue to consider it unreasonable to retrieve organs without family consent.

Despite these problems, it is government policy to create a register and the Ministry of Health is implementing this. ${ }^{79}$ However, this thesis argues that a register is not necessary, as the suggested procedures would ensure that the representative was aware of the appointment and able to demonstrate it. If the delay in locating the representative was likely to be fatal to the use of the organs, the priority list would apply. $^{80}$

\section{Relatives}

The Human Tissue Act 1964 refers to "surviving spouse" "surviving de facto partner" "surviving civil union partner" and "any surviving relative". ${ }^{81}$ The discussion document suggested that these terms are inadequate, in light of the complexity of family relationships, and preferred the wider definition of family suggested in the review of the Coroner's Act. ${ }^{82}$ That review did not address the issue of the priority of these various persons, or how to assess who had "the responsibility for, or an interest

\footnotetext{
${ }^{73}$ See the suggested provision above, regarding the preservation of the body.

${ }^{74}$ The Human Tissue (Organ Donation) Amendment Bill proposes to amend the Human Tissue Act 1964 by establishing a register on which anyone could register their legally binding wish to be an organ donor or state their objection to being an organ donor and registration could not be overridden by relatives.

${ }^{75}$ Human Tissue Bill, clause 41.

${ }^{76}$ Human Tissue Bill, clause 5: "Other donor information" includes a request that the body be used. It is silent as to whether it also includes a request that it not be used.

${ }^{77}$ See the discussion in chapter 2.

${ }^{78}$ There are only around 100 potential deceased donors in New Zealand each year and around 40 of those become cadaveric organ donors.

${ }^{79}$ It is intended to include the register in the Human Tissue Bill, which is likely to be introduced in late 2006.

${ }^{80}$ See above- if the representative was not able to be located the next person on the priority list would be able to give consent.

${ }^{81}$ Human Tissue Act 1964, s 3(2).

${ }^{82}$ Law Commission Coroners: A Review (NZLC R62 Law Commission, Wellington, 2000)

Preliminary Paper 365<http://www.lawcom.govt.nz> (last accessed 27 April 2004).
} 
in, the welfare of the deceased." The delays involved in searching out such persons could be fatal to the utilisation of the organs of a person who had not appointed a representative. The preferred approach is that of the UKHTA, which provides a ranking list $^{83}$ and, if more than one person is equally ranked, it is sufficient to obtain consent from one of them. ${ }^{84}$

As the property interest in the body passes to the representative following death, there would be no need to ascertain how close the relationship must be in order to have decision making power. If no appointment was made, the priority list would apply. $^{85}$

It is possible that a representative's consent to donate organs might be distressing to Māori families, however if the deceased wished his or her bodily property to be dealt with according to tikanga Māori, it is likely the representative would be chosen and instructed accordingly. ${ }^{86}$ An advantage of the property construct is the flexibility to reflect cultural values, if that is wished.

\section{LIVING DONOR TRANSPLANTATION}

This thesis argues that the property interest in body parts arises once they are excised from a living person. As such, at the time of consent to collection of an organ from a living donor, there is no property in existence. Despite this, it is relevant to consider whether the suggested framework provides adequate protection of the rights of such donors. In light of the low cadaveric rates of organ donation and the steadily increasing waiting lists, living donor transplantation (LDT) has social value and should be facilitated. ${ }^{87}$

Many jurisdictions have legislation specifying that procedures that place the donor at unacceptable risk should not be undertaken, ${ }^{88}$ but as is discussed in chapter 6 , there is no empirical evidence that the ethical standards of the medical professionals involved are inadequate, thus necessitating legislative intervention.

In New Zealand there is no explicit statement in law that living organ donation is legitimate, but it is commonly accepted that the source has the right to make such a decision. The HTB will amend the Health and Disability Commissioner Act 1994 to clarify that organ harvest from a living donor is a health treatment so the Code applies to it. ${ }^{89}$

Commentators have argued that there are issues relating to the maxim primum non nocere, and the need to ensure that decisions to donate are made autonomously. Processes and procedures to ensure that the welfare of all participants in LDT is

\footnotetext{
${ }^{83}$ Human Tissue Act 2004 (UK), s 27(4).

${ }^{84}$ Human Tissue Act 2004 (UK), s 27(7).

${ }^{85}$ Human Tissue Act 2004 (UK), s 27. See the priority list above.

${ }^{86}$ See the discussion in chapter 5 .

${ }^{87}$ The Code provides in Right 6 the right to be fully informed and in Right 7 the right to make an informed choice and give informed consent.

${ }^{88}$ Council of Europe Additional Protocol to the Convention on Human Rights and Biomedicine Concerning Transplantation of Organs and Tissues of Human Origin ETS no 186 (Council of Europe, Strasbourg, 2001) art $11<\mathrm{http}: / / w w w . c o e . i n t>$ (last accessed 27 April 2004).

${ }^{89}$ Human Tissue Bill, clause 89.
} 
appropriately safeguarded are essential, as this is an area where property interests, in conjunction with informed consent, may be insufficient to protect donors. ${ }^{90}$ Sources who are considering undergoing a procedure with substantial potential risks, for the benefit of another, should be informed about more than just the nature and risks of the medical procedure. The issues encompass familial, social, and economic factors. Price suggests that legislation should require that the donor has understood the information provided, ${ }^{91}$ although this thesis argues that this is an unreasonable requirement, as indicating understanding does not necessarily mean that the person fully understands all the ramifications, or even cares about them, as many people have decided to donate well before any counselling is provided.

Such safeguards do not weaken the arguments in favour of recognition of property interests in body parts, because the law controls dealings with property, to protect vulnerable persons in other contexts, such as remedies for undue influence, or consumer legislation. The hospital or doctor would obtain possession of the organs only for the purpose in the consent and the living donor retain title until the organs were transplanted into the recipient. The Authority would oversee the retention and use of human tissue, including living organ donations, but unlike the UKHTA, ${ }^{92}$ prior permission of the Authority is not suggested, unless examples of egregious conduct arise. $^{93}$

The Human Tissue Authority has the following functions:

(a) to issue guidelines and advice to ethics committees on any matter relating to living donor transplantation and to keep such guidelines and advice under review:

(b) to provide the Minister with advice on aspects of, or issues arising out of, kinds of living donor transplantation and advice as to whether this Act or another enactment should be amended to prohibit or provide for any kind of living donor transplantation.

In light of the multiplicity of family and other relationships in society, the legislation should not draw any distinction between related and unrelated living donors and should not restrict stranger and paired donations, so long as any requirements in the guidelines were satisfied.

\section{A Children}

This thesis argues that parents may have conflicting interests, particularly with respect to sibling transplantation, so deference to parental decision-making should be curtailed and such decisions made by the Family Court, or the Human Tissue Authority. Children should be protected from multiple procedures, as may be required from a "saviour sibling" who is HLA matched to an ill family member. ${ }^{94}$ They should

\footnotetext{
${ }^{90}$ See the discussion in chapter 3.

${ }^{91}$ David Price "From Cosmos and Damian to Van Velzen: The Human Tissue Saga Continues" (2003)

11 Med L Rev 1, 22.

${ }^{92}$ Human Tissue Act 2004 (UK), s33.

${ }^{93}$ In Germany, legislation has established a Commission that is required, inter alia, to decide whether there are grounds for believing the donor's consent is not being given freely, or that the organ is the object of trade. Act of 5 November 1997, No 74, s 8(2).

${ }^{94}$ C Thomas "Pre-Implantation Testing and the Protection of the "Saviour Sibling"" (2004)

9 Deakin L Rev 119.
} 
be independently represented and relevant factors would include the child's psychological and emotional well-being, as well as physical health. ${ }^{95}$ Recognition of property interests in body parts would enable the property provisions in the Care of Children Act 2004 to further protect the interests of children. ${ }^{96}$

\section{POST-MORTEMS AND RETENTION OF TISSUE}

Non-coronial post-mortems are conducted to provide information about the cause of death of a person. Such examinations can be of benefit to the family of the deceased and may lead to improvements in healthcare delivery. The HTB provides that collection or use of tissue is lawful for the purposes of a lawful post-mortem. ${ }^{97}$ Unconsented secondary use is also permitted if the tissue was from a post-mortem ordered under the Coroners Act 1988 or the Health Act 1956. Otherwise express consent is required. ${ }^{98}$ The retention of tissue from such examinations has caused concerns, such as the retention of children's hearts by Greenlane Hospital. ${ }^{99}$

The person giving consent for such a post-mortem should be informed which tissue is to be retained for the purposes of the post-mortem, the reason for the retention, and the time for which it will be retained. If the tissue is to be retained for any purpose other than the post-mortem, additional consent for that retention should be obtained. This is consistent with the suggested framework, as the representative would give the consent for the post-mortem and give binding instructions as to the ultimate disposition of the tissue, including restricting the types of use and placing time limits on the retention.

\section{FUTURE-PROOFING}

The regulatory framework could include an embargo of any novel process while the regulatory response is determined. This would allow an immediate response, and halt the new development, as an interim measure, while guidelines or legislation were developed. The HART Act provides that an Order in Council could be made imposing a moratorium on any kind of assisted reproductive procedure, or human reproductive research, while advice is developed, for up to two periods of 18 months. ${ }^{100}$

In contrast, the UKHTA gives the Human Tissue Authority the power to license activities relating to the removal, use and storage of human organs and material from a human body. ${ }^{101}$ A variety of activities must be licensed and the Secretary of State may, by regulation, add to, remove, or alter the activities to which the section applies. ${ }^{102}$ This allows for relatively rapid changes; however, there may be a lack of Parliamentary, and thus public, scrutiny of many of the key aspects of the legislation and subsequent changes.

\footnotetext{
${ }^{95}$ See the discussion in chapter 6.

${ }^{96}$ Care of Children Act, ss6 and 14.

${ }^{97}$ Human Tissue Bill, clause 12.

${ }^{98}$ Human Tissue Bill, clause 22.

${ }^{99}$ See the discussion in chapter 2.

${ }^{100}$ Human Assisted Reproductive Technology Act 2004, s 24.

${ }^{101}$ Human Tissue Act 2004 (UK), s 16(2)(e).

${ }^{102}$ Human Tissue Act 2004 (UK), s 16(4).
} 
In light of the strong cultural and personal views held about the human body, it is important that the framework be incorporated in legislation and not be able to be amended by way of regulation. In light of the delays likely while policy is developed, a provision similar to that in the HART Act is recommended. The Human Tissue Bill does not contain similar provisions.

\section{COMMERCIALISATION}

A thriving market for human body parts has developed as new technologies, such as gene sequencing and DNA fingerprinting, have increased the economic value of human tissue. ${ }^{103}$ The UKHTA prohibits the trafficking in human material intended for the purposes of transplantation, ${ }^{104}$ unless the person engaging in the activity is designated by the Human Tissue Authority as a person who may lawfully engage in the activity. ${ }^{105}$ It does not impose a broader prohibition on commercial dealings in bodily material and it exempts gametes, embryos, ${ }^{106}$ hair and nails from a living person, and material that is the subject of property, because of an application of human skill. ${ }^{107}$

\section{A Work and Skill}

Human organs and tissue are frequently processed in complex ways, requiring the investment of work and skill. The UKHTA exempts such products from regulation, as they are the property of the scientist or technician who has applied skill in the manufacture. Thus, histopathological slides, which have been selected, stained, and mounted, are the property of the pathologist who prepared them. However, it is not specified how much, or how little, skill has to be applied to human tissue to make it the subject of property rights. ${ }^{108}$

There seems little conceptual basis to continue this dubious construct which has its basis in the common law. ${ }^{109}$ The sources of the cells used to develop cell lines produced by a technological process retain an interest in the cells. If it is unacceptable for the human sources to profit from their cells, then it is equally unacceptable for others to profit from commercial uses of their cloned cells. Such a view was the basis of the claim made in conversion in Moore. ${ }^{110}$

The provision in the UKHTA, that material might be the subject of property because of an application of human skill, will not, of itself, prevent unethical conduct of commercial companies or remove the contradictions within the common law as to the status of body parts. The UKHTA provides that material shall not be regarded as

\footnotetext{
${ }^{103}$ Emily Waltz "News Feature: The Body Snatchers" (2006) Nature Medicine Online $<$ http://www.nature.com/news/2006> (last accessed 30 May 2006).

${ }^{104}$ Human Tissue Act 2004 (UK), s 32.

${ }^{105}$ Human Tissue Act 2004 (UK), s 32(3).

${ }^{106}$ Gametes and embryos are regulated under the Human Fertilisation and Embryology Act 1990 (UK).

${ }^{107}$ Human Tissue Act 2004 (UK), s 32(a).

${ }^{108}$ See the discussion in chapter 2.

${ }^{109}$ See the discussion in chapter 2.

${ }^{110}$ Moore v Regents of the University of California (1990) 51 Cal 3d 120, 125 (Cal Sup Ct). See the discussion in chapter 3 .
} 
from a human body if it is created outside the human body. ${ }^{111}$ Thus, once a cell line is created, it appears to be exempt from the provisions of the Act, although the human source would have had to consent to use of the tissue. The point at which sufficient work and skill has been applied to transmute the possessory right in the cells into a property right in the cell line is unclear. An alternative interpretation of the UKHTA is that, as the cell line was created outside the body, the Act does not apply. The human source will only be able to recover expenses, but the material will be able to be sold by research institutes, subject to the permission of the Authority.

Chapter 1 argued that excised body parts are property because they assume a character which is different from being part of an entire person. It also argued that donation causes a living donor inconvenience and discomfort. Thus this labour creates a new object, which is the source's property. The actions of doctors or researchers are as agents of the source, so that they do not become the owners unless the source agrees to transfer title or abandons the body part.

\section{B Sale of Organs}

Commentators argue in favour of allowing individuals to sell organs, as this would result in a greater supply and would respect property rights and autonomy. ${ }^{112}$ However, an organ market is unlikely to be politically attractive and it is not proposed in the HTB or in this thesis. Not every "stick" in the bundle of rights needs to exist for a property interest to arise so prohibiting the sale of organs does not necessarily prevent the existence of property rights. As was discussed in chapter 3, there seems scant reason to prevent patient groups or individuals from negotiating contracts with researchers, to provide for payment for research materials or a share of the profits from a patent. ${ }^{113}$

\section{Commercial supply of material from the human body for transplantation}

(1) No person may give or receive, or agree to give or receive, valuable consideration for the supply of any material which:

(a) consists of or includes human cells, and

(b) is, or is intended to be, removed from a human body, and

(c) is intended to be used for the purpose of transplantation.

(2) Every person commits an offence who contravenes subsection (1) and is liable on summary conviction to imprisonment for a term not exceeding 1 year or a fine not exceeding $\$ 100,000$, or both.

\section{Tissue}

Body tissue should not, in general, be used for research purposes unless the human source has agreed to transfer the property interest, or to give a right of possession to the researcher for specified purposes. To give informed consent, the source must be aware of the potential for profit and should be able to enter into

\footnotetext{
${ }^{111}$ Human Tissue Act 2004 (UK), s4 (7).

${ }^{112}$ See the discussion in chapter 1.

${ }^{113}$ See the discussion of PXE International in chapter 3.
} 
contractual profit-sharing arrangements. Patient groups are already negotiating the terms and conditions of research into specific disorders. ${ }^{114}$ People in the position of the Greenbergs ${ }^{115}$ may justifiably wish to ensure that tests and treatments remain accessible to patients with particular disorders, by making contractual arrangements with researchers.

If each research participant individually negotiated a price for each use of the biological material provided to a biobank, this could impede research. However, if the property approach was accepted, the consent form would most likely include any conditions and also a statement that individuals would be paid a predetermined amount for their contribution, or that no payment was offered. Additionally, there would often be a condition that sources thereby gave up any further rights to benefit, should a patent be obtained for an invention. ${ }^{116}$ Ownership in the samples would pass to the biobank.

Sources who did not accept such conditions would refuse to participate. An individual would not usually have attributes that are vital to the research, so individual refusals would not impair the research. If however, the individual contribution is essential, or many prospective participants decline to participate, the offer would need to be amended. Thus, individual negotiations are unlikely in most cases. Only in exceptional situations, such as that of Moore, would an individual be vital for the research and directly contribute to a valuable product. If he had been fully informed, he would have been able to negotiate, or to refuse to participate.

As discussed in chapter 7, patent law should respect the property interest people have in the parts of their bodies and sources should be able to use contractual arrangements to achieve a share relative to their contribution. Patenting of human genes and gene fragments should be restricted, either because it is not an invention or, in light of automated sequencing, because it is "obvious". If patents are allowed for products based on genes, such as diagnostic tests, then licensing should be employed to prevent the restriction of access to tests or treatment to those individuals or States who can afford them.

\section{Reimbursement of Expenses}

The UKHTA allows recovery of expenses or loss of earnings incurred by the person from whose body the material comes, so far as reasonably and directly attributable to supplying the material from the person's body. ${ }^{117}$ In New Zealand people who donate a kidney or liver tissue are eligible for between $\$ 164$ and $\$ 290$ a week for up to three months after surgery, as a contribution toward lost income. Donors are also be given help with additional childcare costs, and do not have to use their sick or annual leave when they take time off work to recover from the operation. $^{118}$

\footnotetext{
${ }^{114}$ See the discussion of PXE International in chapter 3.

${ }^{115}$ See the discussion in chapter 3.

${ }^{116}$ As with UK Biobank.

${ }^{117}$ Human Tissue Act 2004 (UK), s 37(7)(c).

${ }^{118}$ Hon Steve Maharey "Financial Assistance for Live Organ Donors" 28 January 2005.

Ministerial Press Release. See the discussion in chapters 1 and 3.
} 
In light of the preponderance of women donors, ${ }^{119}$ who are more likely than men to not be in paid employment, it would be unfortunate if such a scheme did not include domestic support for such donors and compensate for loss of income of partners who take time off work to care for donors, or their children. As the cost of maintaining a person on dialysis is $\$ 60,000$ to $\$ 80,000$ per year, donors should receive full compensation for their expenses. It is also reasonable to guarantee priority treatment for living donors should they suffer deleterious medical consequences as a result of having donated. The payment of a funeral benefit to the estate of a person who had made provision for the donation of organs after death is also justifiable, as recognition of a socially beneficial act and to encourage procrastinating persons to make decisions.

\section{INSTITUTIONS}

The legislation proposed in this thesis specifies the acceptable parameters for the retention and use of human tissue, including an authority to provide oversight and sanctions for violation of the law. The advantages of this approach are that it creates clear, legally enforceable, rules and that the process of creating legislation engages the public in the development of policy. The disadvantages are the difficulty of defining acceptable and unacceptable uses, inflexibility, and the argument that the state should not intrude into the private domain unless there is empirical evidence of an unacceptable level of harm.

\section{A Ethics Committees}

There is a range of national and local ethics committees in New Zealand, involved in governing the use of tissue obtained from live and deceased human sources. Their roles, which include scrutinising health and disability support research proposals and proposals for innovative practice, would continue under the proposed framework. The Human Tissue Authority would have an overarching role similar to the role of ACART. ${ }^{120}$ It would develop guidelines, which ethics committees would be required to apply to their deliberations, but would not generally undertake case-bycase consideration of research proposals.

\section{B Constitutional Justification}

The ethics review process by ethics committees has come to be viewed as a surrogate for a comprehensive ethical approach to research involving human subjects. The deliberations of ethics committees may result in limits on research, on a case-bycase basis. Such ad hoc public policy may lead to inconsistent decisions because of differences in the way research proposals are presented, or the surrounding circumstances. McDonald has expressed concern that it only covers a narrow time slice of the research. ${ }^{121}$ It involves predicting whether, with the information provided, subjects would be able to make an informed judgment about participation in research and about the potential benefits and harms of research. There is no mechanism to attempt to verify these predictions, to check whether the research proceeded according

\footnotetext{
${ }^{119}$ As discussed in chapter 6.

${ }^{120}$ Human Assisted Reproductive Technology Act 2004, s 36- 41.

${ }^{121}$ Michael McDonald “Anybody Minding the Store?” (2001) 9 Health Law Journal 1, 9.
} 
to the research proposal, whether there was genuine informed consent, and whether the benefit/harm ratio was actually within ethical parameters. McDonald expresses this as a lack of "virtuous learning loops." 122

The Operational Standard requires ethics committees to monitor approved research proposals and researchers to provide progress reports during the research and a final report on completion. ${ }^{123}$ However, committees do not have any powers of enforcement, apart from the ability to withdraw the approval in certain circumstances. In contrast, the HART Act provides considerable enforcement powers to ensure that the Act has been complied with, including that the approval of the ethics committee was obtained for the performance of an assisted reproductive procedure or the conduct of human reproductive research, and that any conditions included in the approval were complied with. ${ }^{124}$

In the absence of public policy about the direction of, or limits to, new technologies, ethics committees must make decisions. One view is that such committees have no right to be restricting the rights of researchers, pending the development of public policy. The alternative view is that no research should be done until public policy is developed. This latter view would delay research that might reduce human suffering and, in any event, public policy cannot be developed until it is known to what it will relate. The most practical view is that, in the absence of public policy, research be permitted to proceed, subject to ethical review by an ethics committee, on a case-by-case basis.

Each application for a grant submitted to the Health Research Council must have an independent ethical assessment of the proposed research. ${ }^{125}$ Section 16 of the HART Act makes it an offence to perform an assisted reproductive procedure, or conduct human reproductive research, without the prior approval in writing of the ethics committee. The legislation prescribes the procedures to be undertaken by the Advisory Committee, including giving interested parties and members of the public a reasonable opportunity to make submissions and taking such submissions into account. ${ }^{126}$ However, it does not prescribe the decision making process. It is suggested that the Human Tissue Authority should be similarly constituted.

The Operational Standard, which is only a guideline, states that health and disability research proposals and innovative treatment protocols should not proceed without ethics committee approval. However, despite the non binding nature of the Operational Standard, it is generally treated by ethics committees as if it were binding, thus assuming the status of "soft law", made by the Ministry of Health and not subject to Parliamentary scrutiny. Use of such de facto regulation has been common recently, for example with regard to the importation of human embryonic stem cell lines ${ }^{127}$ and future research on biobanked material. ${ }^{128}$

\footnotetext{
${ }^{122}$ McDonald, above, 11.

${ }^{123}$ Ministry of Health Operational Standards for Health and Disability Ethics Committees (Ministry of Health, Wellington, 2002) 47 < http://www.moh.govt.nz> (last accessed 20 April 2004).

${ }^{124}$ Human Assisted Reproductive Technology Act 2004, ss 67-75.

${ }^{125}$ Health Research Council Act 1990, s 25.

${ }^{126}$ Human Assisted Reproductive Technology Act 2004, s 39.

${ }^{127}$ Ministry of Health Guidelines on Using Cells from Established Human Embryonic Stem Cell Lines for Research (Ministry of Health, Wellington, 2006).
} 
Ethics committees appear to dominate ethical debate. Committees with prescribed procedures, such as ACART, still have a wide discretion to determine the ethical precepts they will apply. If members of the public oppose the stance taken by an ethics committee, there is no obvious avenue to action such a grievance, other than through the media. Although interested parties may seek a second opinion from the National Advisory Committee, or seek judicial review, such processes are not available to the public.

Ethics committees have been accepted internationally as an acceptable way to oversee and control research and innovative practice. This trend is likely to continue. Despite the above concerns, this thesis proposes the establishment of a Human Tissue Authority with to give advice to the Minister if it determines that regulation is necessary and to prepare binding guidelines for ethics committees.

\section{Human Tissue Authority}

(1) The Minister must establish a committee to be known as the Human Tissue Authority.

(2) The Human Tissue Authority has the following general functions-

(a) maintaining a statement of the general principles which it considers should be followed-

(i) in the carrying-on of activities in schedule 2, and

(ii) in the carrying-out of its functions in relation to such activities;

(b) providing in relation to activities in schedule 2 such general oversight and guidance as it considers appropriate;

(c) superintending, in relation to activities within schedule 2, compliance with(i) requirements imposed under this Act, and

(ii) codes of practice under this Act;

(d) providing to the public, and to persons carrying on activities within schedule 2, such information and advice as it considers appropriate about the nature and purpose of such activities;

(e) monitoring developments relating to activities within schedule 2 and advising the Minister on issues relating to such developments

Schedule 2 would include matters such as the collection of body parts from children and incompetent adults, living donor transplantation, and unconsented use of extant and future biobanked samples. In particular, the role of the Authority would be to increase the protection of vulnerable participants and protect the public interest.

\section{CONCLUSIONS}

\footnotetext{
${ }^{128}$ Ministry of Health Guidelines on the Use of Human Tissue for Future Unspecified Research Purposes: Discussion Document (Ministry of Health, Wellington, 2006). Guidelines on the future use and retention of the heel prick samples are presently being prepared and will include the use of the samples for research.
} 
The framework proposed is based on the concept that research on human tissue and organ donations are social goods and that the public should be encouraged and enabled to permit the use of their body parts. It is argued that the public involvement will increase if there is trust that the sources are able to control and restrict the uses of body parts. This necessitates an ability to take action should the body parts be misappropriated and an ability to enter into contractual arrangements to share in the resultant profits. There is no such power arising from the HTB.

This chapter has demonstrated selected parts of a legal framework incorporating the property structure. Despite concerns about the increasing reliance on ethics committees, it acknowledges there are aspects of the framework that would require oversight, such as living organ donation and some that require case-by-case consideration, such as sibling living organ donation. As such, the establishment of an overarching Human Tissue Authority is recommended. 


\section{CONCLUSIONS}

One's own dead are more than cadavers, they are place holders for the living. They are a focus, a receptacle, for emotions that no longer have one. The dead of science are always strangers. ${ }^{1}$

This thesis argues that organ transplantation and research depend on the ongoing willing involvement of the public which, in turn, requires public trust in the processes involved. The Medical Research Council's public survey into perceptions of the collection of human biological samples ${ }^{2}$ found evidence of public cynicism towards the medical profession generally, but most people continued to find medical research to be worthy and worthwhile. ${ }^{3}$ There was, however, disparate knowledge and understanding of the meaning and goals of research and, where understanding was lacking, there was considerable evidence of negative associations with the research. ${ }^{4}$ This general atmosphere of mistrust is compounded by the increased role of the private sector in undertaking and financing research, including obtaining intellectual property rights over discoveries and products.

Autonomy, which is the dominant ethical precept in western bioethics has, in practice, been taken to mean informed consent. However, autonomy is a universal ethical good, reflecting various different aspects of personhood that are worthy of respect, such as choice, independence, freedom of action, self-governance and control. Consent does not have ethical value in itself, but it does indicate the power to control the body, which is a property-orientated concept and implies and supports an underlying property right. There are various means to respect individuals in a passive sense, including doing no harm and respecting individual privacy. Informed consent has come to be seen as the primary and, arguably, only legitimate way of giving individuals power and control in their dealings with medical professionals and researchers. The thesis has argued that the focus on consent renders the participatory process disempowering, in that it fails to recognise that:

- If a person gives consent to participate in research, he/she thereafter has no control, unless further consent is required. However, the consent to participate in research can be withdrawn at any time and, if the research reaches a new stage, there has to be another informed consent;

- Sources are interested parties in the overall research enterprise and its commercial applications;

- Sources retain an interest in their biological samples;

- There is a need to reconcile conflicts between the interests of previously living donors and their families;

- There is a need to reconcile cultural values regarding collective interests.

\footnotetext{
${ }^{1}$ Mary Roach Stiff: The Curious Life of Human Cadavers (W W Norton \& Co, New York, 2003) 12.

${ }^{2}$ Medical Research Council, Public Perceptions of the Collection of Human Biological Samples

(Medical Research Council, London, 2000).

${ }^{3}$ Medical Research Council , above, para. 2.1.

${ }^{4}$ Medical Research Council, above, para. 2.2.
} 
Individual choices impact on the wider community, particularly in the context of genetic research, which may have repercussions within families or communities. The "communitarian" nature of information from body parts has been recognised in the collective claims of Māori to their genetic heritage. However, the thesis signals the weakening of informed consent in New Zealand with regard to biobanked samples. ${ }^{5}$

American jurisprudence generally uses utilitarian considerations to support the property rights of the recipients of body parts. Moore suggests such rights are necessary to protect researchers, ensure that there are sufficient samples available, provide economic incentives, encourage research, and provide certainty of title. ${ }^{6}$ This thesis argues that there is a lack of empirical evidence of these assertions ${ }^{7}$ and that the further argument that the free exchange research culture might be harmed without such an interest can also be disputed in light of existing commercialisation of research. Economic and certainty of title arguments were countered by suggesting that if sources have property interests, such interests can be transferred by sale or gift. Even if sources may, in some cases, negotiate compensation, this does not necessarily undermine the economic basis of research and adequate record keeping would enable the resolution of issues of title. ${ }^{8}$

The cases tend not to specifically rely on potentially relevant theories of property, such as first occupancy, which is based on the premise that excised body parts are res nullius and ownership is acquired by the first person to take possession. It depends on the source having no rights over the body parts. If it is accepted that sources have an ongoing interest, as is demonstrated by the ability of living organ donors to specify the recipient, then for first occupancy to apply, it would have to be established that the source had abandoned that interest prior to excision.

As this is a difficult argument to sustain, an alternative approach is that the property rights arise because of the labour of the claimant. None of the cases considered apply such an argument to body parts from the living, although it has been applied to cadavers, if work or skill has given the body or parts features beyond their mere existence. ${ }^{9}$ Case law has long stated that there is no property in a dead body, but it was argued that times have changed and there is now ample justification for recognising property interests in a cadaver.

The cases considered do not apply the work and skill exemption to body samples or cell lines, although there is potential for such an argument if it can be shown that the sample has acquired different attributes and that the source had no

\footnotetext{
${ }^{5}$ See the discussion in chapter 3 of the amendment to Right 7(10) in the Code, in chapter 2 the provisions of the Human Tissue Bill and in chapter 8 the Ministry of Health Guidelines on the Use of Human Tissue for Future Unspecified Research Purposes: Discussion document (Ministry of Health, Wellington, 2006).

${ }^{6}$ Moore v Regents of the University of California (1988) 249 Cal Rptr 494 (Cal SC).

${ }^{7}$ Medical Research Council Human Tissue and Biological Samples for Use in Research (Medical Research Council, London, 1999) par 2.4; Australian Law Reform Commission Protection of Human Genetic Information (Discussion Paper 66) (Australian Government Publishing Service, Canberra 2002) paras 17.36-17.37.

${ }^{8}$ Such record keeping forms part of good research practice, in any event.

${ }^{9}$ Doodewood v Spence (1908) 6 CLR 406 (HCA); Dobson v North Tyneside Health Authority [1997] 1 WLR 596 (CA) R v Kelly [1999] QB 621 (CA). These cases are discussed in chapter 2.
} 
underlying property right. Clearly, a cell line is different from the source cells, but in Moore, Mosk $\mathrm{J}$ noted that if the source had a property right in his cells, the patenting of the cell line would not extinguish his proprietary interest. ${ }^{10}$

This thesis argued that the work and skill exemption supports the proposed framework, as a living source suffers inconvenience and discomfort when parts are excised and the work of the doctor is undertaken as agent for the source. The body part then assumes a different character than it had as part of an entire body. Consequently, this forms the basis for the argument that the parts are the source's property.

The proposed Human Tissue Bill was considered and it was concluded that it is inadequate to protect the interests of the source and couldl result in familial conflict and delays. It is essential that sources have confidence that their values and wishes will be respected. Consequently, both dissent and consent should be enforced, despite any conflicting views of family members. The legislation proposed is intended to protect these values, to ensure that sources have confidence that the processes will not override their wishes.

The cases considered in chapter 3 show acceptance of a source's property right in some circumstances, such as Catalona, ${ }^{11}$ where it was accepted that there was such a right initially, which had been gifted to the university. As in Moore, the court was greatly influenced by public policy considerations. In Greenberg, ${ }^{12}$ the claim was based on an assertion that the children owned their tissues. The court held that there was no property interest retained in body tissue and genetic information once it was given voluntarily to the researchers. It did not deny that there was a property interest prior to donation. ${ }^{13}$ This could either be interpreted as an inference that they owned their entire bodies, a proposition not argued in this thesis, or alternatively, that they owned the tissues after excision, at the point of donation. The latter interpretation is in accord with the proposed framework.

Rather than explicitly utilising self ownership to justify property rights, the courts have tended to use autonomy and personal rights. ${ }^{14}$ This thesis argued that legislation incorporating the property construct would promote autonomy, as sources would be able to protect their personal and cultural values and enforce restrictions and limits on the use of their property. This would empower sources to take a more equal role in the partnership that they form when they participate in research. Informed consent has practical limitations and often amounts to little more than a choice between the alternatives on offer. ${ }^{15}$ Property and consent need not be mutually exclusive, as they should operate in tandem to ensure full and proper respect for individual and collective rights. Sources or representatives would only be able to transfer the property interests by giving informed consent.

\footnotetext{
${ }^{10}$ Moore $v$ Regents of the University of California, above, 511.

${ }^{11}$ Washington University $v$ Catalona (2006) US Dist LEXIS 22969 Limbaugh J.

${ }^{12}$ Greenberg and others v Miami Hospital Research Institute and others (Greenberg) (2003) $264 \mathrm{~F}$ Supp 2d 1064 (SD Fla).

${ }^{13}$ Washington University $v$ Catalona, above.

${ }^{14}$ Airedale NHS Trust v Bland [1993] AC 789, 808 (HL); Re A (Children)(Conjoined Twins [2001] Fam 147 (CA) 176. See the discussion in chapter 4.

${ }^{15}$ As discussed in chapter 1.
} 
The gift model has traditionally governed the collection of body parts for transplantation or research. The notion of a "gift" has strong normative appeal, because it is seen as a laudable act, demonstrating the virtues of altruism and beneficence, untainted by self-interest or exploitation. Donation is beneficial for recipients if gifts are treated as unconditional ${ }^{16}$ and future use or disposal of the gift is allowed. ${ }^{17}$ In public interest terms, unconditional gifting can serve a number of valuable social ends, including advances in medical research and organ transplantation.

However, in the current "no property" regime, such a concept of gift is incongruous, because it presupposes underlying property rights or interests in the subject of the gift. There is no clear prohibition on ownership of body parts and there are examples of a property model being applied to human tissues as they can form the basis of patentable inventions, become the property of those who do work on them, be stolen and be subject to criminal law.

Arguments against allowing sources to have a property interest were considered. Two principle concerns are:

- Property interests would hinder research. In the scheme of relative powers, sources are currently disadvantaged and it is not an established fact that research would be obstructed if sources had increased bargaining power. In most cases, their property is likely to be of little economic significance to researchers. Research may be furthered, rather than hindered, by the recognition of property rights, because those previously reluctant to contribute tissue would have an incentive to do so.

- Commercialisation of body parts could lead to exploitation. Although this is true, that prospect is not a sufficient reason to refuse to recognise property rights. Exploitation can be guarded against and, in any case, a black market in body parts already exists. Additionally, this argument is open to challenge from an autonomy perspective, on the grounds of paternalism.

The framework proposed combines a property interest with existing processes, such as informed consent. It provides that a property interest in a cadaver arises briefly at the point of death and living persons would be able to make binding dispositions providing for their interest in their bodies to pass to their representative on death. The duty of that person would be to carry out the wishes of the deceased. The representative would either transfer the material unconditionally to the institutions carrying out transplantation or research or permit them to possess the material until the permitted use is complete. In the latter case, the hospital or researcher would obtain possessory rights to the materials, subject to conditions, and the representative, could take action if the materials were misused. Once organs were transplanted to another, they would become part of that person and no longer subject to property interests. An essential aspect is that that the property interest is only part of the larger medico-legal structure, rather than a total solution.

\footnotetext{
${ }^{16}$ Although it is accepted that living donors may specify the recipient of the organ.

${ }^{17}$ As was the basis of the decision in Washington University v Catalona (2006) US Dist LEXIS 22969 Limbaugh J.
} 
In the research context, there would be a distinction made between those samples previously collected and future collection of samples. With respect to samples collected in the past, it is accepted that it may be impractical to obtain consent from the sources, as they may be difficult to trace, or dead. There are potential public health benefits from utilising biobanked material, so legislation would permit the use of material collected prior to a specified date, for purposes approved by an ethics committee. The proposed Human Tissue Authority would provide oversight and produce guidelines for ethics committees. Ownership of the extant samples would pass to the researcher as if the samples had been abandoned, subject to the conditions imposed by the ethics committee. Ethics committees could only approve the research use of extant samples if they were anonymised and the committee was satisfied that the research was not of a sensitive nature or culturally offensive. Sanctions would apply if the conditions imposed by the committee were breached, the approval would be revoked and all material and information would be returned to the biobank or destroyed.

At the time of consent to the future collection of samples, the source or the representative of a deceased person could specify the ongoing status of the property interest. Either the property would be unconditionally transferred or limited possessory rights would be authorised, with remedies available for breaches. If the research purpose was unknown at the time of collection, generic consent would be necessary. The source could impose conditions, such as restricting the types of research, putting a time limit on use, reserving the right to withdraw permission at any time, requiring the return or destruction of the samples and specifying re-contact if the research revealed relevant medical information. This is not informed consent, because the person consenting is not able to be informed in advance about the specific nature of the research, but it does overcome the problem of repeatedly requiring renewed consents for different projects once generic consent has been given.

Although there are arguments in favour of permitting the sale of organs, such commercialisation is politically unattractive and the framework would prohibit it, while allowing living donors to recover reasonable expenses and the estates of deceased sources to be paid a funeral benefit. Prohibiting the sale of organs would not exclude property interests, as not all of the incidents of property must be present for the assertion of ownership rights.

As stated, the primary objections to a property-based approach relate to concerns that the source might profit, as other parties, such as patent holders and operators of commercial bio-banks, already profit from body parts. It was argued that sources should be able to control, and profit from, patents based on their body parts. The refusal to grant such rights undervalues their contributions to the inventive process. Contractual arrangements could provide for compensation in proportion to the contribution to the invention. Some contractual negotiations could be undertaken by the Human Tissue Authority, rather than by individual sources, to avoid multiple negotiations by researchers and the imposition of a burden on sources. However, individuals or patient groups would be able to elect to negotiate on their own behalf.

This thesis recognises that body parts and corpses have cultural significance. A New Zealand framework must respect Māori cultural values, and comply with Treaty obligations. As Māori are very diverse, the property interest in human body 
parts would rest with the individual, who could choose whether or not to engage in collective decision making. This decision would not be imposed by regulation. Compliance with Māori cultural values should be focussed on the approval of research proposals, ${ }^{18}$ rather than at the point of sample collection.

Existing statutory property protection regimes would apply to the property interests of incompetent sources. The Human Tissue Authority would decide whether to authorise living organ donation, rather than the source's family. Although competent living organ donors may experience pressures to donate, it is suggested that this should be addressed by way of robust consent procedures, rather than legislative intervention. The Human Tissue Authority would be required to oversee LDT practices and, should the need for additional controls become apparent, provide advice accordingly to the Minister.

This thesis expresses disquiet about the increasing tendency to delegate decision making to ethics committees. This provides flexibility but if ethics committees are empowered to make policy there is a risk that the democratic process will be usurped. However, even more concerning is the common practice of government departments that produce "soft law" by developing "guidelines", which are treated as though they are binding.

Ethics committee appointment processes should be more transparent, to avoid capture by interest groups. Members who are appointed to represent specific interest groups, such as Māori, should be required to reflect the views of a reasonable member of that group, rather than their personal viewpoints.

This thesis recommends the creation of a Human Tissue Authority to ensure a rapid response to technological developments and to provide oversight and promulgate guidelines in areas where a property interest alone cannot ensure appropriate protection for vulnerable persons. Ethics committees would consider caseby-case applications within the guidelines produced by the Authority.

As stated by Charo: ${ }^{19}$

\begin{abstract}
Ultimately the debate is less about whether the management of human tissue should be governed by property laws or by a more robust regulatory scheme than about the proper balance between respect for persons and the collective interest in promoting research involving human tissue.
\end{abstract}

An adequate legal and ethical framework for the retention and use of human body parts must ensure respect for, and protection of, sources while encouraging participation in research and organ donation. The framework should also protect the interests of researchers, health professionals and organ recipients. These interests may at times be in opposition, but a workable solution is necessary, in light of the long waiting lists for organs and the potential to reduce human suffering through research

\footnotetext{
${ }^{18}$ Before ethics committees approve research using Māori tissue, wānanga (discussions) should undertaken with the whānau (family) or iwi (tribe) involved in the research, to discover whether there are culturally acceptable processes or practices that will enable the research to be undertaken. See chapter 5.

${ }^{19}$ R Alto Charo "Body of Research- Ownership and Use of Human Tissue" (2006) 355 N Engl J Med $1517,1519$.
} 
outcomes. This thesis sets out a legislative framework with demonstrative examples of suggested legislation that incorporates property interests in body parts. It argues that this approach would yield ethical goods, as it would encourage participation in transplantation and research and thus, reduce mortality and suffering. 


\section{BIBIOGRAPHY}

\section{ARTICLES}

Alldridge, $\mathrm{P}$ "Consent to Medical and Surgical Treatment-The Law Commission's Recommendations” (1996) 4 Med L Rev 129.

Anderlik, Mary R and Mark A Rothstein "Canavan Decision Favors Researchers Over Families" (2003) $31 \mathrm{~J}$ law med ethics 450.

Andrews, Lori B "Who Owns Your Body? A Patient's Perspective on Washington University v Catalona" (2006) J Law Med Ethics 398.

Andrews, Lori B “My Body, My Property” (1986) Hastings cent rep 16.

Andrews, Lori B “The Body as Property: Some Philosophical Reflections-A Response to J F Childress" (1992) 24 Transplant proc 2149.

Andrews, Lori B and Dorothy Nelkin "Whose Body Is It Anyway? Disputes Over Body Tissue in a Biotechnology Age" (1988) 351 Lancet 53.

Andrews, Lori B "The Gene Patent Dilemma: Balancing Commercial Incentives with Health Needs" (2002) Hous J Health L \& Pol'y 65.

Austin, Graeme "Righting a Child's Right to Refuse Medical Treatment" (1992) 7 Otago L Rev 578.

Bailey, James "An Analytical Framework for Resolving the Issues Raised by the Interaction Between Reproductive Technology and the Law of Inheritance" (1998) 47 DePaul L Rev 743.

Barrad, Catherine M Valerio "Comment, Genetic Information and Property Theory" (1993) 87 Northwestern L Rev 1037.

Barton, J H "Research-tool Patents: Issues for Health in the Developing World" (2002) 80 Bull World Health Organ 121.

Berg, K “The Ethics of Benefit Sharing” (2001) 59 Clin genet 240.

Bernstein, D M and R G Simmons "The Adolescent Kidney Donor: The Right to Give" (1974) 131 Am j psychiatr 1338.

Beyleveld, Deryck and Roger Brownsword "My Body, My Body Parts, My Property?” (2000) 8 Health care anal 87.

Black, Julia "Regulation as Facilitation: Negotiating the Genetic Revolution" (1998) 61 MLR 621.

Bobrow, Martin and Sandy Thomas "Patents in a Genetic Age" (2001) 409 Nature 763. 
Boukhart B "What is Property?” (1990) 13 Harv J L \& Pub Pol’y 775.

Boulier, William "Sperm, Spleens and Other Valuables: The Need to Recognise Property Rights in Human Body Parts" (1993) 23 HOFSTRA L Rev 693.

Brams, J "Transplantable Human Organs: Should their Sale be Authorised by State Statutes?” (1977) 3 Am J Law and Med 183.

Brett, A S and L B McCulloch "When Patients Request Specific Interventions: Defining the Limits of the Physician's Obligation" (1986) 315 N Engl j med 1347.

Brower, V "Mining the Genetic Riches of Human Populations" (1998) 16 Nature Biotechnology 337.

Brownsword, Roger "Stem Cells, Superman, and the Report of the Select Committee" (2002) 65 MLR 568.

Burrows, B “The Thoughts of a Patented Man” (1996) Earth Island Journal 27.

Cahill, Lisa Sowle “The New Biotech World Order” (1999) 29 Hastings cent rep 29.

Cain, Amy S Pignatella "Property Rights in Human Biological Materials: Studies in Species Reproduction and Biomedical Technology” (2000) 17 Ariz J Int'1 \& Comp Law 449.

Callaghan, Daniel "The Social Sciences and the Task of Bioethics" (1999) 128 Daedalus 1

Callender, Clive O “Organ Donation in Blacks: A Community Approach.” (1987) 19 Transplant proc 1551.

Campbell, Courtney S "Religion and the Body in Medical Research" (1998) 8 Kennedy Inst Ethics J 275.

Caplin, Arthur L "Blood, Sweat, Tears, and Profits: The Ethics of the Sale and Use of Patient Derived Materials in Biomedicine" (1985) 33 Clinical Res 448.

Carr, N and others "The Autopsy: Lessons from the National Confidential Enquiry into Perioperative Deaths" (2002) 95 J R Soc Med 328.

Caulfield, T A and others "Genetic Technologies, Health Care Policy and the Patent Bargain” (2003) 63 Clin genet 15.

Caulfield, T A "Gene Patents, Human Clones, and Biotechnology Policy: The Challenges Created by Globalization” (2003) 41 Alberta L Rev 713.

Cecka, J and P Terasaki "Living Donor Transplants: Superior Success Rates Despite Histoincompatibilities" (1997) 29 Transplant proc 203. 
Chamberlain, Jenny "To Give or Not to Give?" North and South (March 2004) 33.

Cheyette, Cara "Organ Harvests from the Legally Incompetent: An Argument Against Compelled Altruism" (2000) 41 B C L Rev 465.

Cohen, Philip “Donor's Dread: Why Do Children Who Help a Sick Sibling End up Depressed?” (1997) 155 New Scientist 20.

Crespi, Gregory S "Overcoming the Legal Obstacles to the Creation of a Futures Market in Bodily Organs" (1994) 55 Ohio St L J 1.

Crespi R “An Analysis of Moral Issues Affecting Patent Inventions in the Life Sciences: A European Perspective" (2000) 6 Science and Engineering Ethics 157.

Crouch, C and C Elliott "Moral Agency and the Family: The Case of Living Related Organ Transplantation" (1999) 8 Cambridge Quarterly of Healthcare Ethics 275.

Dalton, R “When Two Tribes Go to War" (2004) 430 Nature 500.

Demetz, J “Toward a Theory of Property Rights” (1967) 57 Am econ rev 347.

Dickens, Bernard "Excised Organs Prior to Implantation: Belonging and Control" (1990) 22 Transplant proc 1000.

Dickens, Bernard "The Control of Living Body Materials" (1977) 27 U Toronto L J 142.

Dickenson, Donna "Commodification of Human Tissue: Implications for Feminist and Development Ethics" (2002) 2 Developing World Bioethics 55.

Dobson, Roger "More Women Than Men Becoming Living Donors" (2002) 325 BMJ 851.

Dodson, Michael and Robert Williamson "Indigenous Peoples and the Morality of the Human Genome Diversity Project (1999) 25 J med ethics 204.

Drahos, Peter "Indigenous Knowledge, Intellectual Property and Biopiracy: Is a Global Bio-Collecting Society the Answer?" (2001) 6 EIPR 245.

Dreschsler, C T “Annotation. Application and Effect of 'Shop Right Rule' or Licence Giving Employer Limited Rights in Employees' Inventions and Discoveries” (1958) 61 ALR 2d 356.

Dressler, R "Feeding the Hunger Artists: Legal issues in Treating Anorexia Nervosa" (1984) Wis L Rev 297. 
Dufault, Rachel M "Bone Marrow Donations by Children: Rethinking the Legal Framework in Light of Curran v Bosze" (1991) 24 Conn L Rev 211.

Durie, M H "Māori Attitudes to Sickness, Doctors and Hospitals" (1977) 86 NZMJ 483.

Dworkin, G and I Kennedy "Human Tissue: Rights in the Body and its Parts" [1993] 1 Med L Rev 291.

Dyer, Clare "Human Tissue Bill is Modified Because of Research Needs" (2004) 328 BMJ 1518.

Eisenberg, Rebecca S "Patents and the Progress of Science: Exclusive Rights and Experimental Use” (1989) 56 U Chi L Rev 1017.

Elliott, Carl "Doing Harm: Living Organ Donors, Clinical Research and the Tenth Man" (1995) $21 \mathrm{~J}$ med ethics 91.

Ellis, I and G Mannion "Humanity versus Utility in the Ethics of Research on Human Genetic Material" (2001) 1 Genetics Law Monitor 1.

Emson, H E "It is Immoral to Require Consent for Organ Donation" (2003) 29 J med ethics 125 .

Engelhardt, H T and M A Rie "Morality for the Medical-Industrial Complex: A Code of Ethics for the Mass Marketing of Health Care"(1988) 319 N Engl J Med 1086.

Erin, C and J Harris "Presumed Consent or Contracting Out" (1999) 25 J med ethics 365.

Evans, Roger W "Organ Procurement Expenditures and the Role of Financial Incentives" (1993) 269 JAMA 3113.

Feenan, Dermot “Case Commentary: A Good Harvest? Re Y (Mental Incapacity: Bone Marrow Transplant)" (1997) 9 CFLQ 305.

Feldman, D "Human dignity as a Legal Value_-Part I" [1999] Public Law 682.

Fellner, C H and J R Marshall "Kidney Donors: the Myth of Informed Consent" (1970) 126 Am j psychiatr 1245.

Feinberg, Joel "Autonomy, Sovereignty, and Privacy: Moral Ideas in the Constitution?" (1983) 58 Notre Dame L Rev 445.

Fienberg, Joel “The Mistreatment of Dead Bodies” (1985) 15 Hastings cent rep 31.

Fishbach, Gerald D and Ruth L Fishbach "Stem Cells: Science, Policy and Ethics" (2004) 114 J Clinic investig 1364. 
Friele, Minou Bernadette "Do Committees Ru(i)n the Bio-Political Culture? On the Democratic Legitimacy of Bioethics Committees” (2003) 17 Bioethics 301.

Freund, B L and K Siegel "Problems in Transition Following Bone Marrow Transplantation: Psychosocial Aspects" (1986) 56 Am j orthopsychiatr 244.

Gaber, A and others "An Assessment of the Impact of Required Request Legislation on the Availability of Cadaveric Organs for Transplantation" (1990) 22 Transplant proc 318 .

Gey, G O, W D Coffman and M T Kubicek "Tissue Culture Studies of the Proliferative Capacity of Cervical Carcinoma and Normal Epithelium" (1952) 12 Cancer res 264.

Gillon, R "Medical Treatment, Research and Informed Consent” (1989) 15 JME 3.

Gitter, Donna M “Ownership of Human Tissue: A Proposal for Federal Recognition of Human Research Participants' Property Rights in their Biological Materials" (2004) 61 Wash \& Lee L Rev 257.

Glantz, Leonard H "Research with Children” (1998) 24 Am J Law and Med 213.

Glantz, Leonard H and others 'Research in Developing Countries: Taking 'Benefit' Seriously" (1998) Hastings cent rep 38.

Gold, Richard "Owning Our Bodies: An Examination of Property Law and Biotechnology” (1995) 32 San Diego L Rev 1167.

Gorman, Christine and David Bjerklie "The Ultimate Sacrifice" (2002) 159 Time 40781.

Greely, Henry T "Breaking the Stalemate: A Prospective Regulatory Framework for Unforeseen Research Uses of Human Tissue Samples and Health Information" (1999) 34 Wake Forest L Rev 737.

Grubb, A ““I, Me, Mine”: Bodies Parts and Property” (1998) 2 Med L int 299.

Gutmann, Amy and Dennis Thompson "Deliberating About Bioethics" (1997) 27 Hastings cent rep 38.

Hammond C "Property Rights in Human Corpses and Human Tissue: The Position in Western Australia” (2002) 4 U Notre Dame Australia L Rev 97.

Hanson, Mark J "Biotechnology and Commodification within Health Care" (1999) 24 $\mathrm{J}$ med philos 267 .

Harris, John "Human Beings, Persons and Conjoined Twins: An Ethical Analysis of the Judgment in $\operatorname{Re} A$ " (2001) 9 Med L Rev 231.

Harris, John “Who Owns My Body?”(1996) 16 Oxf j leg stud 55. 
Harrison, Charlotte $\mathrm{H}$ "Neither Moore nor the Market: Alternative Models for Compensating Contributors of Human Tissue" (2002) 28 Am J Law and Med 77.

Heller, Michael A and Rebecca S Eisenberg "Can Patents Deter Innovation? The Anticommons in Biomedical Research" (1998) 280 Science 698.

Henry, Ella and Hone Pene "Kaupapa Maori: Locating Indigenous Ontology, Epistemology and Methodology in the Academy" (2001) 8 Organization 234.

Hill, Anne Nichols “Note: One Man's Trash is Another Man's Treasure, Bioprospecting: Protecting the Rights and Interests of Human Donors of Genetic Material" (2002) 5 J Health Care L \& Pol'y 259.

Ho, Cynthia "Who Deserves the Patent Pot of Gold?: An Inquiry into the Proper Inventorship of Patient Based Discoveries" (2002) Hous J Health L \& Pol'y 107.

Hoeyer, K, B-O Olofsson, T Mjorndal and N Lynoe "Informed Consent and Biobanks: A Population-based Study of Attitudes Towards Tissue Donation for Genetic Research" (2004) 32 Scandinavian Journal of Public Health 224.

Hohfeld, Wesley "Fundamental Legal Conceptions as Applied in Judicial Reasoning" (1913) 23 Yale L J 16.

Huffman, F "Coerced Donation of Body Tissues: Can We Live with McFall v Shimp? (1979) 40 Ohio St L J 409.

Huxtable, Richard "Case Commentary: Time to Remove the 'Flack Jacket'? Re M (Medical Treatment: Consent)" (2000) 12 CFLQ 83.

Irwin, K "Maori Research methods and Processes: An Exploration" (1994) 28 Sites Journal 25.

Penner J E "The "Bundle of Rights" Picture of Property" (1996) 43 UCLA Law Rev 711.

Jaffe, Erik "She's Got Bette Davis's Eyes: Assessing the Nonconsensual Removal of Cadaver Organs under the Takings and Due Process Clauses" (1981) 90 Colum L Rev 528.

Jamrozik , Konrad "The Case for a New System for Oversight of Research on Human Subjects" (2000) 26 J med ethics 334.

Jennet, B and C Hessett "Brain Death in Britain as Reflected in Renal Donors" (1981) BMJ 359-62.

Jensen, Troy R "Comment: Organ Procurement: Various Legal Systems and their Effectiveness” (2000) 22 Hous J Int'1 L 555. 
Jeungst, E "Group identity and human diversity: keeping biology straight from culture" (1998) 63 American Journal of Human Genetics 673.

Jeunst, Eric T "Commentary: What "Community Review" Can and Cannot Do" (2000) $28 \mathrm{~J}$ law med ethics 52.

Jonas, H "Philosophical Reflections on Experimenting With Human Subjects" (1969) 98 Daedelus 219.

Jones, Howard W and Lucinda Veeck "What is an Embryo?"(2002) 77 Fertility and Sterility 658.

Kappelman, Elysa R "The Dead Donor Rule and the Concept of Death: Severing the Ties that Bind Them" (2003) AJOB 1.

Karakatsanis, K G and J N Tsanakas "A Critique on the Concept of 'Brain Death"” (2002) 18 Issues law med 127.

Kaylor, Liise K and others "Gender Imbalance and Outcomes in Living Donor Renal Transplantation in the United States" (2003) 3 American Journal of Transplantation 452.

Kaylor, Liise K and others "Gender Imbalance in Living Unrelated Donor Renal Transplantation" (2002) 73 Transplantation 248.

Kennedy, I and G Dworkin "Human Tissue: Rights in the Body and its Parts" (1993) 1 Med L Rev. 291.

Keown, J "Restoring Moral and Intellectual Shape to the Law after Bland" (1997) 113 LQR 481.

Kerridge I H, P Saul, M Lowe and others "Death, Dying and Donation: Organ Transplantation and the Diagnosis of Death" (2002) 28 J med ethics 89.

Kirby, Michael "Genomics and Democracy- A Global Challenge" (2003) 31 WALR 1.

Kluge, Eike-Henner W "Patenting Human Genes: When Economic Interests Trump Logic and Ethics" (2003) 11 Health care anal 119.

Lee, Robert G and Derek Morgan "Regulating Risk Society: Stigmata Cases, Scientific Citizenship \& Biomedical Diplomacy” (2001) 23 Sydney L R 297.

Levine, Robert J "Research That Could Yield Marketable Products from Human Materials: The Problem of Informed Consent" (1986) IRB 6.

Lewis, Greg and Neil Pickering "Māori Spiritual Beliefs and Attitudes towards Organ Donation" (2003) NZ bioeth j 31. 
Lewis, Penney "Procedures That Are Against the Medical Interests of Incompetent Adults" (2002) 22 Oxf j leg stud 575.

Liddell, Kathleen and others "Medical Research Involving Incapacitated Adults: Implications of the EU Clinical Trials Directive 2001/20/EC" (2006) $14 \mathrm{Med}$ L Rev 367.

Lockemeyer, David S “At What Cost Will the Court Impose a Duty to Preserve the Life of a Child?” (1991) Clev State L Rev 577.

Luskin, Richard S and Francis L Delmonico "Assessing Organ Donation from the Dead Should Not be done by Reporting a Census of the Living" (2003) 3 American Journal of Transplantation 1185.

MacBean, Alexandra "The Patentability of Human Beings: The Effect of a Proposed Exclusion in the Patents Act 1953" (2002) 33 VUWLR 379.

Marshall, Eliot "Policy on DNA Research Troubles Tissue Bankers" (1996) 271 Science 440.

Mason, J K and G T Laurie "Consent or Property? Dealing with the Body and its Parts in the Shadow of Bristol and Alder Hey" (2001) 64 MLR 710.

Matthews, Paul "Whose Body? People as Property" (1983) 36 CLP 193.

Matthews, Paul “The Man of Property” [1995] Med L Rev 251.

McCormick, Richard A “Abortion: A Changing Morality and Policy?” (1979) Hospital Progress 36.

McDonald, Michael “Anybody Minding the Store?” (2001) 9 Health law j 1.

McHale, Jean "Waste Ownership and Bodily Products" (2000) 8 Health care anal 123.

Mead, Aroha Te Pareake "Genealogy Sacredness and the Commodities Market" (1996) 20 Cultural Survival Quarterly 46.

Merz, Jon F and others "Protecting Subject's Interests in Genetics Research" (2002) 70 Am J Hum Genet 965.

Mooney, P R “The Gene Piracy” (1994) Frontline 91.

Mossoff, Adam "What is Property? Putting the Pieces Back Together" (2003) 45 Ariz L Rev 371.

Mueller, Janice M 'No 'Dilettante Affair': Rethinking the Experimental Use Exception to Patent Infringement for Biomedical Research Tools" (2001) 76 Wash L Rev 1.

Mumford, S E "Bone Marrow Donation- The Law in Context” (1998) 10 CFLQ 13. 
Munzer, Stephen R “An Uneasy Case against Property Rights in Body Parts” (1994) 11 Social Philosophy and Policy 259.

Munzer, Stephen R “The Special Case of Property Rights in Umbilical Cord Blood for Transplantation" (1999) 51 Rutgers L Rev 493.

Neri, Rebecca M “New Organ Donations” (2002) 10 Digest 67.

O’Carroll, Thomas L “Over My Dead Body: Recognizing Property Rights in Corpses” (1996) 29 HOSPLW 238.

Owen, Allison "Death Row Inmates or Organ Donors: China's Source of Body Organs for Medical Transplantation” (1995) J Ind Int'l and Comp L Rev 495.

Pahl, Susan "Removal of Body Parts: the Legal Position" [1993] NZLJ 144.

Pallis, C “ABC of Brain Stem Death” (1983) BMJ 123.

Paul, Ellen F “Natural Rights and Property Rights” (1990) 13 Harv J L Pub Pol’y 10.

Pearson, I Y, P Bazely, T Spencer-Lane and others "A Survey of Families of Brain Dead Patients: Their Experiences, Attitudes to Organ Donation and Transplantation." (1995) 23 Anaesthesia and Intensive Care 88.

Peart, Nicola "Health Research with Children: The New Zealand Experience" (2000) 3 Current Legal Issues 421.

Pellegrino, Edmund D “The Metamorphosis of Medical Ethics: A 30-year Retrospective" (1993) 269 JAMA 1158.

Penner, J E “The 'Bundle of Rights' Picture of Property” (1996) 43 UCLA L Rev 711.

Pennisi, Christopher S "More on Moore: A Novel Strategy for Compensating the Human Sources of Patentable Cell-Line Inventions Based on Existing Law" (2001) 11 Fordham Intell Prop Media \& Ent LJ 747.

Perley, Sharon Nan "From Control Over One's Body to Control Over One's Body Parts: Extending the Doctrine of Informed Consent." (1992) 67 NYU L Rev 335.

Prainsack, Barbara "Negotiating Life': The Regulation of Human Cloning and Embryonic Stem Cell Research in Israel" (2006) 36 Social Studies of Science 173.

Price, David "From Cosmos and Damian to Van Velzen: The Human Tissue Saga Continues" (2003) 11 Med L Rev 1.

Radin, Margaret "Property and Personhood" (1982) 34 Stan L Rev 957. 
Ramsey, Sarah "UK Government Signals Cautious Go-Ahead for Stem-Cell Research" (2000) Lancet 657.

Rao, Radhika "Property, Privacy, and the Human Body" (2000) 80 BUL Rev 359.

Ravitsky, Vardit "Posthumous Reproduction Guidelines in Israel” 2004 Hastings cent rep 6.

Reed, O Lee “What is 'Property”?" (2004) 41 Am Bus LJ 459.

Resnik, David "The Human Genome Project: Ethical Problems and Solutions" (1999) 18 Politics and Life Sciences 15.

Resnik, David B “DNA Patents and Human Dignity” (2001) 29 J law med ethics 152.

Roake, Justin "Gifts of Life in Short Supply” (2002) 115 NZMJ 1159.

Robbennolt, Jennifer K, Victoria Welsz and Craig M Lawson "Advancing the Rights of Children and Adolescents to be Altruistic: Bone Marrow Donation by Minors" (1994) 9 J L\& Health 213.

Roberts, C "The Prospects of Success of the National Institute of Health's Human Genome Application" (1994) 1 EIPR 30.

Robertson, V and others "Concentrated Professional Education to Implement Routine Referral Legislation Increases Organ Donation" (1998) 30 Transplant proc 214.

Rose-Ackerman, Susan "Inalienability and the Theory of Property Rights" (1985) 85 Colum L Rev 931.

Ross, Lainie Friedman "Donating a Second Kidney: A Tale of Family and Ethics" (2000) 13 Seminars in Dialysis 201.

Ross, Lainie Friedman "Moral Grounding for the Participation of Children as Organ Donors" (2001) 21 J law med ethics 251.

Santiago-Delpin, Eduardo "Additional Guidelines on the Use of Minors as Living Kidney Donors” (2003) 3 American Journal of Transplantation 1182.

Savell, Kristin "Human Rights in the Age of Technology: Can Law Rein in the Medical Juggernaut?” (2001) 23 Sydney L R 423.

Schoeman, Ferninand "Rights of Children, Rights of Parents, and the Moral Basis of the Family" (1980) 91 Ethics 8.

Schoeman, Ferninand "Parental Discretion and Children's Rights: Background and Implications for Medical Decision-Making” (1985) 10 J Med \& Phil 48. 
Seeney, Erik B "Moore 10 Years Later- Still Trying to Fill the Gap: Creating a Personal Property Right in Genetic Material” (1998) 32 New Eng L Rev 1131.

Shann, F “A Personal Comment: Whole Brain Death Versus Cortical Death" (1995) 23 Anaesthesia and Intensive Care 14-15.

Sharp, Richard R and Morris W Foster "Community Involvement in the Ethical Review of Genetic Research: Lessons from American Indian and Alaska Native Populations" (2002) 110 Environ health perspect 145.

Shartle, Bryan "Proposed Legislation for Safely Regulating the Increasing Number of Living Organ and Tissue Donations by Minors" (2001) 61 La L Rev 433.

Sheard, Andrew "Patenting Human Genes: Reflections on the Public Debate" (2002) 8 Journal of Commercial Biotechnology 235.

Sheldon Sally and Stephen Wilkinson "On the Sharpest Horns of a Dilemma: Re A (Conjoined Twins)” (2001) 9 Med L Rev 201.

Shewmon, D Alan "The Brain and Somatic Integration: Insights Into the Standard Biological Rationale for Equating "Brain Death" with Death" (2001) 26 J Med \& Phil 457.

Skegg, D "The Removal and Retention of Cadaveric Body Parts: Does the Law Require Parental Consent?" (2000) 10 Otago L Rev 425

Skegg, P D G "Human Corpses, Medical Specimens and the Law of Property" (1975) 4 Anglo-Am L R 412.

Streat, Stephen "Clinical Review: Moral Assumptions and the Process of Organ Donation in the Intensive Care Unit" (2004) 8 Critical Care 382.

Skene, L "Proprietary Rights in Human Bodies, Body Parts and Tissue" (2002) 22 Legal Studies 102.

Spital, A “Should Children Ever Donate Kidneys?” (1997) 64 Transplantation 232.

Spital, A "Unconventional Living Kidney Donors- Attitudes and Use among Transplant Centres" (1989) 48 Transplantation 243.

Stern, K “Advance Directives” (1994) 2 Med L Rev 57.

Stone, Adam "The Strange Case of John Moore and the Splendid Stolen Spleen" (1996)

$<$ http://socrates.berkeley.edu:4050/moore.html $>$ (last accessed 10 September 2004).

Streeb, C L “A child conceived After his Father's Death?: Posthumous Reproduction and Inheritance Rights. An Analysis of Ohio Statutes" (2000) 48 Cleve St L Rev 137. 
Thomas C "Pre-Implantation Testing and the Protection of the "Saviour Sibling"" (2004) 9 Deakin L Rev 119.

Thurow, Lester "Globalization: The Product of a Knowledge Based Economy" (2000) 570 Ann Am Acad Polit Soc Sci 19.

Trouet, C "New European Guidelines for the Use of Stored Human Biological Materials in Biomedical Research" (2004) 30 J med ethics 99.

Truog, R D “Is it Time to Abandon Brain Death?” (1997) 27 Hastings cent rep 29.

Veatch, Robert M "Limits of Guardian Treatment Refusal: A Reasonableness Standard" (1983) 9 Am J Law and Med 427.

Wagner, Allen B “The Legal Impact of Patient Materials Used for Product

Development in the Biomedical Industry" (1985) 33 Clinical Res 444.

Wagner, Lynn “Tough Rules Urged for Tissue Banks” (1992) Mod Healthcare 17.

Waltz, Emily “The Body Snatchers” (2006) 12 Nature Medicine 48.

Watson, R “MEPs Protest at Patent for Breast Cancer Gene” (2001) 323 BMJ 888.

Weijer, Charles “The Quest for Legitimacy: Comment on Cox MacPherson's 'To Strengthen Consensus, Consult the Stakeholders"' (2004) 18 Bioethics 293.

Wendler, D "Informed Consent, Exploitation and Whether it is Possible to Conduct Research Without Either One" (2000) 14 Bioethics 310.

Wetzel, Randall C and others "Hemodynamic Responses in Brain Dead Organ Patients" (1985) 64 Anaesthesia \& Analgesia 125.

Williams, Christian "Combating the Problems of Human Rights Abuses and Inadequate Organ Supply through Presumed Donative Consent" (1994) 26 Case W Res J Int'l L 315.

Williamson, A R “Gene Patents: Are They Socially Acceptable Monopolies, Essential for Drug Discovery?” (2001) 6 Drug Discovery Today 1092.

Wilson, $\mathrm{P}$ "Body Crime! Human Organ Procurement and Alternatives to the International Black Market" (1991) 30 Trends and Issues in Crime and Criminal Justice 34.

Wolfslast, G "Legal Aspects of Organ Transplantation” (1992) 11 J heart lung transplant 160.

Youngner, Stuart C, C S Landefeld, CJ Coulton and others “"Brain Death' and Organ Retrieval: A Cross-sectional Survey of Knowledge and Concepts among Health Professionals" (1989) 261 JAMA 2205. 


\section{LEGISLATION}

\section{New Zealand}

Administration Act 1969.

Care of Children Act 2004.

Health and Disability Commissioner's Code of Health and Disability Services Consumers' Rights.

Crimes Act 1961.

Crown Minerals Act 1991.

Environment Act 1986.

Health (Cervical Screening (Kaitiaki) Regulations 1995.

Health (National Cervical Screening Programme) Amendment Act 2004.

Health Act 1956.

Human Assisted Reproductive Technology Act 2004.

Human Tissue Act 1964.

Human Tissue Bill.

New Zealand Bill of Rights Act 1990.

New Zealand Public Health and Disability Act 2000.

Patents Act 1953.

Protection of Personal and Property Rights Act 1988.

Resource Management Act 1991.

Treaty of Waitangi Act 1975.

Wills Act (UK) 1837.

\section{United States}

National Organ Transplant Act 42 USC §273-274 (f).

Public Health Service Act 42 USC § 264 (1994).

Uniform Anatomical Gift Act (amended 1987), 8A ULA § 19.

\section{Australia}

Human Tissue Act 1982 (NSW).

Human Tissue Act 1982 (Vic).

Human Tissue Act 1985 (Tas).

Human Tissue Amendment Act 1987 (Vic).

Human Tissue and Transplantation Amendment Act 1987 (WA).

Human Tissue Transplant Act 1979 (NT).

Reproductive Technology Act 1988.

Transplantation and Anatomy Act 1979 (Qld).

Transplantation and Anatomy Ordinance 1978 (ACT).

\section{United Kingdom}

Human Fertilisation and Embryology Act 1990.

Human Tissue Act 1961.

Human Tissue Act 2004. 


\section{CASES}

AB v Leeds Teaching Hospital NHS Trust [2004] EWHC 644 (QB).

Airedale NHS Trust v Bland [1993] AC 789 (HL).

Arnaud v Odom (1989) 870 F 2d 304 (5 $5^{\text {th }}$ Cir).

Attorney General's Reference (No 3 of 1994) [1996] QB 581 (HL).

Auckland Area Health Board v Attorney-General [1993] 1 NZLR 235 (HC).

Awa v Independent News Auckland Ltd [1995] 3 NZLR 701 (HC).

$A Z v B Z$ (2000) 431 Mass 150 (Mass Probate Ct).

Bleakley v Environmental Risk Management Authority [2001] 3 NZLR 213 (HC).

Bogert v City of Indianapolis (1859) 13 Ind 120.

Brotherton v Cleveland (1990) 923 F 2d 477 ( $6^{\text {th }}$ Cir $)$.

Brown v Regents of the University of California (1994) 866 F Supp 439 (DN Cal).

Burton v Islington HA [1992] 3 All ER 820(CA).

$C v S$ [1987] 1 All ER 1230 (QB), [1988] QB 135 (CA).

Case of Dickson v United Kingdom European Court of Human Rights, Application no 44362/04, 18 April 2006.

Clark v Landon General Omnibus Co Ltd [1906] 2 KB 648 (CA).

Colavito v New York Organ Donor Network Inc (2006) 438 F 3d 214; 2006 US app LEXIS 4309 (US App Ct).

Cornelio v Stamford Hospital (1997) WL 430619 (Conn Super Ct) aff'd by (1998) 717 A 2d 140 (Conn).

Culpepper v Pearl St Building (1994) 877 P 2d 877 (Colo).

Curran v Bosze (1990) 566 NE 2d 1319 (Ill Sup Ct).

Davis v Davis (1992) 842 SW 2d 588 (Tenn Sup Ct).

Diamond v Chakrabarty (1980) 448 US 303 (SC).

Dobson and Another v North Tyneside Health Authority and Another [1996] 4 All ER 474 (CA). 
Doodeward v Spence (1908) 6 CLR 406 (HCA).

Environmental Risk Management Authority Decision GMD02028 (ERMA, Wellington, 2002).

Environmental Risk Management Authority Decision GMF98001 (ERMA, Wellington, 2002).

Environmental Risk Management Authority Decision GMF98009 (ERMA, Wellington, 2002.

Ericka Grimes $v$ Kennedy Krieger Institute Inc; Myron Higgins a minor et al $v$ Kennedy Krieger Institute Inc (2001) 366 Md. 29; 782 A 2d 807 (Ct App Md)

Evans v Amicus Healthcare Ltd [2003] EWHC 2161 (Fam).

General Electric Co Ltd's Application (Patent) [1961] RPC 21.

Georgia Lions Eye Bank Inc v Lavant (1985) 335 SE 2d 127 (Ga).

Gillick v West Norfolk and Wisbech AHA [1986] AC 112 (HL).

Greenberg and others v Miami Hospital Research Institute and others (2003) $264 \mathrm{~F}$ Supp 2d 1064 (SD Fla).

$H v G(14$ May 1999) High Court Auckland M1868/98 Salmon J.

$H v W(1995)$ FLC 92-598 (FCA).

Hall v Fertility Institute of New Orleans (1994) 647 So 2d1348 (La Ct App).

Harrild v Director of Proceedings [2002] NZAR (HC).

Harrild v Director of Proceedings [2003] 3 NZLR 289 (CA).

Hart v Brown (1972) 289 A 2d 386 (Ill Sup Ct).

Haynes' case (1614) 12 Co Rep 113, 77 ER 1389.

Hecht v Superior Court (1993) 20 Cal Rptr 2d 275 (Ct App).

Hopkins v Blanco (1974) 320 A 2d 139 (Sup Ct Pa).

In re Guardianship of Pescinski (1975) 67 Wis 2d 4 (Wisc Sup Ct).

Kass v Kass (1998) 91 NY 2d 554 (NY Ct App).

Kingdom of the Netherlands $v$ European Parliament and Council of the European Union case C-377/98 [2000] ECR I-6229. 
Little v Little (1979) 576 SW 2d 493 (Tex Civ).

McFall v Shimp (1978) No 78-17711 10 Pa, (1978) D\&C 3d 90 (Pa).

McFarlane v Tayside Health Board [2000] 2 AC 59 (HL) 114.

Miles Inc v Scripps Clinic and Research Foundation (1991) 951 F $2 d 361$ (9 ${ }^{\text {th }}$ Cir).

Monsanto Co v Stauffer Chemical Co (No 1) (1984) 1 NZIPR 518 (HC).

Moore v Regents of the University of California (1988) 202 Cal App 3d $1230 \mathrm{Cal}$ Reptr 494 (Cal Ct App).

Moore v Regents of the University of California (1990) 793 P 2d 479; 51 cal 3d 120 (Sup Ct Cal).

Mount Isa Mines Ltd v Pusey (1970) 125 CLR 383 (HCA).

NRDC v Commissioner of Patents (1959) 102 CLR 252.

New Zealand Māori Council v Attorney General [1987] 1 NZLR 641 (CA).

Onyeanusi v Pan Am (1992) 952 F 2d 788 (3d Cir).

Paton v Trustees of BPAS and another [1978] 2 All ER 987 (CA).

Pharmaceutical Management Agency Limited v Commissioner of Patents [2000] 2 NZLR 529 (CA).

Pierce v Society of Sisters (1925) 268 US 510 (Sup Ct).

Prince v Massachusetts (1944) 321 US 158 (Sup Ct).

Quintavalle v Human Fertilisation and Embryology Authority [2005] UKHL 28 (HL).

$R$ (Quintavalle) $v$ Secretary of State for Health [2002] EWCA Civ 29, [2002] 2 All ER 625 (HC).

$R$ (Quintavalle) $v$ Secretary of State for Health [2003] UKHL 13, [2003] 2 All ER 113 (HL).

$R v$ Human Fertilisation and Embryology Authority ex $p$ Blood [1997] 2 FLR 756 (CA).

$R v$ Kelly, $R v$ Lindsay [1999] QB 621 (CA).

$R v$ Secretary of State for Health, ex parte Bruno Quintavalle (on behalf of Pro-Life Alliance) [2001] EWHC 918 (Admin) [2001] 4 All ER 1013 (HC). 
$R v$ Sharpe (1857) Dears \& Bell 160.

$R v X$ (18 October 2004) Court of Appeal CA 299/04 McGrath, Hammond, William Young JJ.

Rance v Mid-Downs Health Authority [1991] 1 QB 587 (QB).

Re A (Children) (Conjoined Twins: Surgical Separation) [2000] 4 All ER 961(CA).

Re an Unborn Child [2003] 1 NZLR 115 (HC).

Re Baby P [An Unborn Child] (1995) 13 FRNZ 472 (Fam).

$\operatorname{Re} C$ [1997] 2 FLR 180 (Fam D).

Re C (Adult Refusal of Medical Treatment) [1994] 1 WLR 290 (Fam D).

Re E (A Minor: Medical Treatment) [1993] 1 FLR 386 (Fam D).

$\operatorname{Re} F[1990] \mathrm{AC} 1$ (CA and HL).

Re F (In Utero) [1988] 2 All ER 193 (CA).

Re F (Mental Patient: Sterilisation) [1990] 2 AC 1(HL).

Re $G W W$ and $C M W(1997)$ FLC $992-748$ (FCA).

Re J (A Minor) (Wardship: Medical Treatment) [1992] 4 All ER 614 (CA).

Re J (An Infant) [1995] 3 NZLR 73 (HC).

Re M (Medical Treatment: Consent) [1999] 2 FLR 1097 (Fam D).

Re MB (Medical Treatment) [1997] 8 Med LR 217(CA).

Re C (Adult Refusal of Medical Treatment) [1994] 1 WLR 290 (Fam D).

Re R (A Minor) (Wardship: Medical Treatment) [1992] Fam1 (CA).

Re S (A Minor) (Consent to Medical Treatment) [1994] 2 FLR 1065 (Fam D).

Re W(1992) 3 WLR 758 (CA).

Re $W[1993]$ Fam 64 (Fam D).

Re X(1990) 7 FRNZ 216 (HC).

Re Y (Mental Incapacity: Bone Marrow Transplant) [1996] 2 FLR 787; [1997] 2 WLR 556 (Fam D). 
Rees v Darlington Memorial Hospital NHS Trust [2004] 1 AC 309 (HL) 349.

Renigan v Wright (1890) 25 NE 822 (Ind).

Roche $v$ Douglas as administrator of the Estate of Edward John Hamilton Rowan (Dec) [2000] WASC 146 (WASC).

$S v S ; W v$ Official Solicitor [1972] AC 24 (HL).

$S v T$ [2003] NZFLR 223 (HC).

Shortland $v$ Northland Health [1998] 1 NZLR 433 (CA).

State of Queensland v Alyssa Nolan \& Anor [2001] QSC 174 (QSC).

State v Powell (1986) 497 So 2d 1188 (Fla).

Strunk v Strunk (1969) 445 SW 2d 145 (Ky Ct App).

Swift and Company v Commissioner of Patents [1960] NZLR 775 (SC).

$T v S$ [2005] NZFLR 4 (CA) Anderson P, Hammond and William Young JJ.

Tillman v Detroit Receiving Hospital (1985) 360 NW 2d 275 (Mitch Ct App).

Tilousi v Arizona State University Board of Regents No 04-CV-1290-PCT-FJM (3 March 2005).

United States v Arora (1994) 860 F Supp 1091 (D Md).

Washington University v Catalona (2006) US Dist LEXIS 22969.

Whaley $v$ County of Tuscola (1995) 58 F 3d 1111 (6 ${ }^{\text {th }}$ Cir), cert denied (1995) $116 \mathrm{~S}$ $\mathrm{Ct} 476$.

Williams $v$ Williams [1881-5] All ER Rep 840; 20 Ch D 659.

Wisconson v Yoder (1972) 406 US 205 (Wisc Sup Ct). 


\section{TEXTS}

Adams, P Fatal Necessity: British Intervention in New Zealand 1830-1847 (Oxford University Press, Auckland, 1977).

Alderson, Priscilla Choosing for Children: Children's Consent to Surgery (Oxford University Press, Oxford, 1990).

American Medical Association Council on Ethical and Judicial Affairs Code of Medical Ethics: Current Opinions with Annotations (American Medical Association, Chicago, 2000).

Andrews, Lori B and Dorothy Nelkin Body Bazaar (Crown Publishers, New York, 2001).

Baird, D and others Whose Genes Are They Anyway? (Health Research Council of New Zealand, Auckland, 1995).

Barlow, C Tikanga Whakaaro: Key concepts in Maori Culture (Oxford University Press, Auckland, 1991).

Beauchamp, T L and J F Childress Principles of Biomedical Ethics (2 ed, Oxford University Press, New York, 1983).

Becker, Lawrence C Property Rights: Philosophic Foundations (Routledge and K Paul, London, 1977).

Bent, S A and others Intellectual Property Rights in Biotechnology Worldwide (Macmillan, Basingstoke, 1987).

Best, Elsdon Maori Escatology (Kiwi Publishers, Christchurch, 1998).

Bovenberg, Jasper A Property Rights in Blood, Genes and Data (Martinus Nijhoff, Boston, 2006).

British Medical Association Our Genetic Future: The Science and Ethics of Genetic Technology (Oxford University Press, Oxford, 1992).

Brody, Baruch The Ethics of Biomedical Research: an International Perspective (Oxford University Press, Oxford, 1998).

Beyleveld, Deryck and Roger Brownsword Human Dignity in Bioethics and Biolaw (Oxford University Press, Oxford, 2001).

Brownmiller, Susan Against Our Will: Men, Women, and Rape (Simon and Schuster, New York, 1975).

Catterall, H Judicial Cases Concerning American Slavery and the Negro (Irish University Press, Shannon, 1968). 
Chapman, A R (ed) Perspectives in Gene Patenting: Science Religion Industry and Government in Dialogue (American Association for the Advancement of Science, Washington DC, 1999).

Childress, J Who Should Decide? Paternalism in Health Care (Oxford University Press, New York, 1982).

Clerk, J F, W H B Lindsell and A M Armitage Clerk and Lindsell on Torts (17 ed, Sweet and Maxwell, London, 1995).

Coke, Sir Edward The Third Part of the Institutes of the Laws of England Concerning High Treason, and Other Pleas of the Crown and Criminal Causes (W Clarke and Sons, London, 1817).

Collins, G and others (eds) Procurement Preservation and Allocation of Vascularized Organs (Kluwer, Dordrecht, 1997).

Cornish, W R Intellectual Property: Patents, Copyright, Trade Marks and Allied Rights (Sweet and Maxwell, London, 1989).

Davis, KPD (ed) Health and Society (Oxford University Press, Auckland, 1998).

Durie, Mason Whaiora: Māori Health Development (Oxford University Press, Auckland, 1994).

Engelhardt, H T The Foundations of Bioethics (Oxford University Press, New York, 1986).

Faden, Ruth M and Tom L Beauchamp A History and Theory of Informed Consent (Oxford University Press, Oxford, 1986).

Carolyn Faulder Whose Body is it? The Troubling Issue of Informed Consent (Virago Press, London, 1985).

Frankel, S and G McLay Intellectual Property in New Zealand (Lexis Nexis Butterworths, Wellington, 2002).

Garrett, Thomas M, Harold W Baillie, Rosellen M Garrett Health Care Ethics (4 ed, Prentice-Hall, NJ, 2000).

Garwood-Gowers, A J Tingle, and T Lewis Healthcare Law: The Impact of the Human Rights Act 1998 (Cavendish, London, 2001).

Gaus, Gerald F "Property, Rights and Freedom" in Ellen Frankel Paul, Fred D Miller Jr and Jeffrey Paul (eds) Property Rights (Cambridge University Press, Cambridge, 1994).

Gervais, K Redefining Death (Yale University Press, New Haven, 1986). 
Gewirth, Alan The Community of Rights (University of Chicago Press, Chicago, 1996).

Gold, E Richard Body Parts: Property Rights and the Ownership of Human Biological Materials (Georgetown University Press, Washington DC, 1996).

Halsbury's Laws of England (4 ed, Butterworths, London, 1980) Vol XX Gifts.

Harris, J W Property and Justice (Clarendon Press, Oxford 1966).

Harris, John The Value of Life: An Introduction to Medical Ethics (Routledge \& Kegan Paul, London, 1985).

Harris, John Wonderwoman and Superman: The Ethics of Human Biotechnology (Oxford University Press, New York, 1992).

Hauboldt, Richard H Cost Implications of Human Organ and Tissue Transplantations, An Update 1996 (Milliman and Robertson Inc, Minneapolis, 1996).

Heubel, F "Defining the Functional Body and its Parts: A Review of German Law" in H Ten Have, J Welie and S Spicker (eds) Ownership of the Human Body (Kluwer, Dordrecht, 1998).

Hegel, G Philosophy of Right (T Knox trans) (Oxford University Press, Oxford, 1967).

Helmberger, Pat S Transplants: Unwrapping the Second Gift of Life (Chronimed Publishing, Minneapolis, 1992).

Hodgskin, Thomas The Natural and Artificial Right of Property Contrasted (1832) 18

Honoré, Tony Making Law Bind: Essays Legal and Philosophical (Oxford University Press, Oxford, 1987).

Hyde, Lewis The Gift: Imagination and the Erotic Life of Property (Vintage Books, New York, 1983).

Janis, I and L Mann Decision Making: A Psychological Analysis of Conflict Choice and Commitment (The Free Press, New York, 1977).

Kant, I Fundamental Principles of the Metaphysics of Morals T Abbott (trans) (Bobbs Merrill Co Inc, Indianapolis, 1946).

Kelly, J A Short History of Western Legal Theory (Oxford University Press, Oxford, 1992).

Kidney Foundation of New Zealand The Gift of Life (Kidney Foundation of New Zealand, Wellington, 1995). 
King, Michael (ed) Te Ao Hurihuri: The World Moves On (Hicks Smith \& Sons/Methuen NZ Ltd, Auckland, 1977).

Kuhse, Helga and Peter Singer (eds) A Companion to Bioethics (Blackwell Publishers Ltd, Oxford, 1998).

Lamb, David Organ Transplants and Ethics (Routledge, London, 1990).

Laslett, P (ed) Two Treatises of Government (Cambridge University Press, Cambridge, 1960).

Laurie, Graeme Genetic Privacy A Challenge to Medico-Legal Norms (Cambridge University Press, Cambridge, 2002).

Lee, Robert and Derek Morgan (eds) Death Rites: Law and Ethics at the End of Life (Routledge, New York, 1996).

Locke, John The Second Treatise of Government Thomas P Peardon (ed) (The Liberal Arts Press Inc, New York, 1952).

Locke, John An Essay Concerning Human Understanding Book II (Oxford University Press, London, 1964).

Mason, J K and R A McCall Smith Law and Medical Ethics (5 ed, Butterworths, London, 1999).

Mauss, M The Exchange of Gifts W D Halls (trans) (Routledge, London, 1990).

Morgan, Derek Issues in Medical Law and Ethics (Cavendish Publishing Limited, London, 2001).

Munzer S R A Theory of Property (CUP, Cambridge, 1990).

Narveson, Jan The Libertarian Idea (Temple University Press, Philadelphia, 1988.

Nozick, Robert Anarchy, State and Utopia (Basil Blackwell, Oxford, 1974).

Overall, C, L Code and S Muller (eds) Feminist Perspectives: Philosophical Essays on Method and Morals (University of Toronto Press, Toronto, 1988).

Pallis, C and D H Harley ABC of Brainstem Death (BMJ Publishing Group, London, 1996).

Palmer, Norman and Ewan McKendrick (eds) Interests in Goods (Lloyd's of London Press, London, 1993).

Paton, H L (ed) Groundwork of the Metaphysics of Morals (Hutchinson, London, 1953).

Paton, H L The Moral Law (Hutchinson, London, 1966). 
Penner J E The Idea of Property in Law (2ed, Clarendon Press, Oxford, 1997).

Posner R A Economic Analysis of Law (5ed, Aspen, New York, 1998).

Posy, Darrell A and Graham Dutfield Beyond Intellectual Property: Toward Traditional Resource Rights for Indigenous Peoples and Local Communities (International Development Research Centre, Ottawa, 1996).

Potts, John T and Roger Herdman Non-Heart-Beating Organ Transplantation: Medical and Ethical Issues in Procurement (National Academy Press, Washington DC, 1997).

Price, David Legal and Ethical Aspects of Organ Transplantation (Cambridge University Press, Cambridge, 2000).

Radin, Margaret Contested Commodities (Harvard University Press, Cambridge, Massachusetts, 1996).

Reich, Warren Thomas (ed) Encyclopaedia of Bioethics (2 ed, Macmillan, New York, 1995).

Ross, William David The Right and the Good (Hackett Publishing Co Inc, Indiana, 1988).

Rothman, David Strangers at the Bedside: A History of How Law and Bioethics Transformed Medical Decision Making (Basic Books, New York, 1991).

Ryan Alan, Property (University of Minnesota Press, Minneapolis, 1987).

Scott, Russell The Body as Property (Viking Press, New York, 1981).

Shortland, Edward Traditions and Superstitions of the New Zealanders (Longman Brown Green, Longmans \& Roberts, Paternoster Row, 1856).

Simmons, R and others, Gift of Life: The Effects of Organ Transplantation on Individual Family and Societal Dynamics (Transaction Books, New Brunswick, 1987).

Simmons, R and S Klein The Social and Psychological Impact of Organ Transplantation (Wiley, New York, 1977).

Singer, Peter Rethinking Life and Death (Oxford University Press, Oxford, 1994).

Spielman, B (ed) Organ and Tissue Donation: Ethical Legal and Policy Issues (Southern Illinois University Press, Carbondale, 1997).

Strahan, James Andrew A General View of the Law of Property (2 ed, Stevens and Sons Ltd, London, 1897). 
Te Whaiti, P, M McCarthy and A Durie (eds) Mai I Rangiatea: Maori Wellbeing and Development (Auckland University Press \& Bridget Williams Books, Auckland, 1997).

Thompson, Judith Jarvis The Realm of Rights (Cambridge University Press, Cambridge, 1990).

TNS Human Embryo Research Qualitative Research Report (TNS, Wellington, 2006).

Toi te Taiao The Bioethics Council The Cultural, Ethical and Spiritual Aspects of Animal-to-Human Transplantation (Bioethics Council, Wellington, 2005).

Victoria University of Wellington Department of Geography Labour Employment and Work in New Zealand (Victoria University, Wellington, 1995).

Waldron, Jeremy The Right to Private Property (Oxford University Press, New York, 1990).

Williams, Glanville Textbook of Criminal Law (2 ed, Stevens, London, 1983).

Youngner, Stuart J, Robert M Arnold, and Renie Schapiro (eds) The Definition of Death: Contemporary Controversies (The John Hopkins Press, Baltimore, 1999).

Youngner, Stuart J, Renee Fox and Lawrence O'Connell (eds) Organ Transplantation: Meanings and Realities (University of Wisconsin Press, Madison, 1977).

Zaner, R M (ed) Death: Beyond the Whole-Brain Criteria (Kluwer Academic Publishers, Dordrecht, 1988).

\section{REPORTS.}

Agreement on Trade-Related Aspects of Intellectual Property Rights: Annex 1C of Marrakesh Agreement Establishing the World Trade Organization, (15 April 1994) Marrakesh, Morocco http://www.wto.org/english/tratop_e/trips_e/t_agm0_e.htm (last accessed 8 May 2005).

Auckland District Health Board Body Parts Tissues and Substances Review Panel Report (Auckland District Health Board, Auckland, 2002).

Australian Health Ethics Committee of the National Health and Medical Research Council Ethical Issues in Donation of Organs or Tissues by Living Donors (Australian Government Publishing Service, Canberra, 1997). 
Australian Law Reform Commission Essentially yours: The Protection of Human Genetic Information in Australia (Australian Law Reform Commission, Sydney, 2003) ALRC $96<$ http://www.alrc.gov.au> (last accessed 8 May 2005).

Bioethics Council The Cultural, Ethical and Spiritual Dimensions of the Use of Human Genes in Other Organisms (Toi te Taiao, the Bioethics Council, Wellington, 2004).

Cambridge Genetics Knowledge Park and King's College Bioethics Research Centre Report of Human Tissue Workshop King's College Cambridge (Cambridge Genetics Knowledge Park, Cambridge, 2004)

$<$ http://cgkp.org.uk/topics/human_tissue/htw_report.doc $>$ last accessed 14 May 2005),.

CIOMS Round Table Conference Bankowski, Zbigniew and Robert Levine (eds)

Ethics and Research on Human Subjects: International Guidelines:

Proceedings of the XXVIth CIOMS Conference, Geneva, Switzerland, 5-7

February 1992 (CIOMS, Geneva, 1993).

Convention for the Protection of Human Rights and Dignity of the Human Being with Regard to the Application of Biology and Medicine: Convention on Human Rights and Biomedicine (4 April 1997) CETS No 164.

Council of Europe Explanatory Report to the Convention on Human Rights and Biomedicine (17 December 1996)

$<$ http://conventions.coe.int/Treaty/en/Reports/Html/164.htm $>$ (last accessed 14 February 2005).

Council of Europe Instrument on the use of archived human biological materials in biomedical research (Council of Europe, Strasbourg, 2002)

$<$ http://www.coe.int $>$ (last accessed 17 February 2005).

Council on Ethical and Judicial Affairs of the American Medical Association The Use of Minors as Organ and Tissue Donors Report 56, (American Medical Association, Chicago, 1994).

Danish Council of Ethics Report The Criteria of Death (Danish Council of Ethics, Copenhagen, 1988).

Department of Health A Code of Practice for the Diagnosis of Brain Stem Death: Including Guidelines for the Identification and Management of Potential Organ and Tissue Donors (Department of Health, London, 1988).

Department of Health Circular Memorandum No 1986/70 (Department of Health, Wellington, 1986).

Department of Health $A$ Code of Practice for Transplantation of Cadaveric Organs (Department of Health, Wellington, 1987). 
European Parliament Directive on the Legal Protection of Biotechnological Inventions Directive 98/44/EC (European Parliament, Strasbourg, 1998) $<$ http://www.europarl.eu.int $>$ (last accessed 1 April 2005).

Gibbs, N Genetically Modified Organisms and Maori Cultural and Ethical Issues Commissioned by the Ministry for the Environment (Ministry for the Environment, Wellington, 1998).

House of Commons The Royal Liverpool Children's Inquiry Report HC [session 2000-2001] 112-II (The Stationery Office, London, 2001).

House of Commons Science and Technology Committee Human Reproductive Technologies and the Law (The Stationery Office, London, 2005) $<$ http://www.publications.parliament.uk/pa/cm/cmsctech.htm\#reports $>$ (last accessed 30 March 2005).

House of Lords Stem Cell Research (HL Paper 83 (i) (Report) and 83 (ii) (Evidence) The Stationery Office, London, 2002).

House of Lords Select Committee on Science and Technology, Science and Society (HMSO, London, 2000).

Human Fertilisation and Embryology Authority Sex Selections: Options for Regulation (Human Fertilisation and Embryology Authority, London, 2003).

Human Genetics Society of Australasia Response to ALRC: Issues Paper 27 Gene Patenting and Human Health (Human Genetics Society of Australasia Victoria, 2003) <http://www.hgsa.com.au> (last accessed 1 April 2005).

Jackson, Moana The Maori and the Criminal Justice System, a New Perspective: He Whaipanga Hou Part 2 (Department of Justice Policy and Research Division, Wellington, 1988).

Law Commission Coroners: A Review (Preliminary Paper 36, Law Commission, Wellington, 1999).

Law Commission Mentally Incapacitated Adults and Decision-Making: Medical Treatment and Research (Consultation Paper no 129, Law Commission, Wellington, 1993).

Law Commission for England and Wales Mentally Incapacitated Adults and Decision-Making: Medical Treatment and Research, Consultation Paper No 129 (Law Commission, London, 1993).

Law Commission for England and Wales Consent in Criminal Law: Consultation Paper (Law Com No 139 HMSO, London, 1995). 
Law Reform Commission of Canada Procurement and Transfer of Human Tissues and Organs (Working Paper 66, Minister of Supply and Services, Ottawa, 1992).

Matthiessen-Guyader, Line (ed) Survey of Opinions from National Ethics Committees or Similar Bodies, Public Debate, and National Legislation in Relation to Human Embryonic Stem Cell Research and Use (European Commission, Brussels, September 2003) $<$ http://europa.eu.int/comm/research/biosociety/pdf/catalogue_stem_cells.pdf $>$ (last accessed 14 March 2005).

Medical Research Council Human Tissue and Biological Samples for Use in Research (Medical Research Council Ethics Series, London, 2001).

Medical Research Council Public Perceptions of the Collection of Human Biological Samples (Medical Research Council, London, 2000).

Ministerial Committee on Assisted Reproduction Technologies Assisted Human Reproduction: Navigating Our Future (Department of Justice, Wellington, 1994).

Ministry of Commerce Maori and the Patenting of Life Form Inventions: An Information Paper Produced by the Patenting of Life Forms Focus Group (Putahi Associates for the Ministry of Commerce, Wellington, 1999).

Ministry of Economic Development Review of the Patents Act 1953: Boundaries to Patentability (Ministry of Economic Development, Wellington, 2002).

Ministry of Economic Development Review of the Patents Act 1953 Stage 3: Boundaries to Patentability (Ministry of Economic Development, Wellington, 2003).

Ministry of Economic Development Memorandum to Cabinet Policy Committee: Report Back with Recommendations and Options for Addressing Genetic Material Patents (Ministry of Economic Development, Wellington, 2004).

Ministry of Health Review of the Regulation of Human Tissue and Tissue-based Therapies (Ministry of Health, Wellington, 2004).

Ministry of Health Guidelines on the Use of Human Tissue for Future Unspecified Research Purposes Discussion Document (Ministry of Health, Wellington, 2006).

Ministry of Health Cabinet Paper Review of the Regulation of Human Tissue and Tissue-based Therapies: Paper three: Additional Matters Relating to the Therapeutic and Non-therapeutic Use of Human Tissue (Ministry of Health, Wellington, 2005).

Ministry of Health Operational Standards for Ethics Committees (Ministry of Health, Wellington, 2002). 
Ministry of Health The Consent, Storage and Use of Newborn Blood Spot Cards: a Public Consultation Draft (Unpublished- copy held by author).

National Advisory Committee on Health and Disability Support Services Ethics Kāhui Matatika o te Motu Review of the Current Processes for Ethical Review of Health and Disability Research in New Zealand (Ministry of Health, Wellington, 2004).

National Bioethics Advisory Commission Ethical and Policy Issues in Research Involving Human Participants Volume 1 (National Bioethics Advisory Commission, US Department of Commerce, Virginia, 2001).

National Bioethics Advisory Commission Ethical Issues in Human Stem Cell Research (National Bioethics Advisory Commission, US Department of Commerce, Virginia, 1999).

National Bioethics Advisory Commission Research Involving Human Biological Materials Ethical Issues and Policy Guidance (National Bioethics Advisory Commission, US Department of Commerce, Virginia, 1998).

National Ethics Committee on Assisted Human Reproduction Guidelines for the Storage, Use, and Disposal of Sperm from a Deceased Man (Ministry of Health, Wellington, 2000).

New Zealand Royal Commission on Genetic Modification Report of the Royal Commission on Genetic Modification (Royal Commission, Wellington, 2001).

Ngā Kaihautu Tikanga Taiao Report on GMD02028 (transgenic cattle) (ERMA, Wellington, 2002).

Ngā Kaihautu Tikanga Taiao Report to the Environmental Risk Management Authority (GMF 98009) (ERMA, Wellington, 1999).

Ngā Kaihautu Tikanga Taiao Report to the Environmental Risk Management Authority (GMF 98001) (ERMA, Wellington, 1998).

Nuffield Council on Bioethics Report Human Tissue: Ethical and Legal Issues (Nuffield Council on Bioethics, London, 1995) $<$ http://www.nuffield.bioethics.org $>$ (last accessed 14 March 2005).

Nuffield Council on Bioethics The Ethics of Patenting DNA (Nuffield Council on Bioethics, London, 2002) <http://www.nuffield.bioethics.org $>$ (last accessed 14 March 2005).

Parliamentary Commissioner for the Environment Proposed Guidelines for Local Authority Consultation with Tangata Whenua (Parliamentary Commissioner for the Environment, Wellington, 1992). 
President's Commission for the Study of Ethical Problems in Medicine and Biomedical and Behavioral Research Defining Death: Medical Legal and Ethical Issues in the Determination of Death (Government Printing Office, Washington DC, 1981).

President's Council on Bioethics Human Cloning and Human Dignity: An Ethical Inquiry (President's Council on Bioethics, Washington DC, 2002).

Privacy Commissioner Guthrie Tests (Privacy Commissioner, Wellington, 2003).

Responsiveness Unit, State Services Commission, Partnership Dialogue: A Māori Consultation Process (State Services Commission, Wellington, 1989).

Royal College of Pathologists Consensus Statement of Recommended Policies for Uses of Human Tissue in Research Education and Quality Control (Royal College of Pathologists, London, 1999).

Royal College of Psychiatrists Guidelines for Researchers and for Research Ethics Committees on Psychiatric Research Involving Human Participants (Royal College of Psychiatrists, London, 2001).

Scottish Executive Final Report of the Independent Review on the Retention of Organs at Post Mortem (Scottish Executive, Edinburgh, 2001).

Select Committee on Science and Technology, Human Genetics: The Science and its Consequences HC 1994-95 HC Paper 41(The Stationery Office, London, 1995).

Statistics New Zealand New Zealand Now: Māori (Department of Statistics, Wellington, 1998).

Te Puni Kōkiri A Guide for Departments on Consultation with Iwi (Te Puni Kōkiri, Wellington, 1993).

Te Puni Kōkiri Hauora o te Tinana me ona Tikanga (Te Puni Kōkiri, Wellingon, 1999).

The Royal Society Stem Cell Research and Therapeutic Cloning: An Update (The Royal Society, London, 2000) <http://www.royalsoc.ac.uk> (last accessed 8 April 2005).

The United States Congress Office of Technology Assessment New Developments in Biotechnology: Ownership of Human Tissues and Cells-Special Report (US Government Printing Office, Washington DC 1987).

Third Report of the Conference of European Health Ministers (Paris, 16-17 November 1987) Organ Transplantation: Legislative Measures in Relation to Organ Transplantation and to European Cooperation (Council of Europe, Strasbourg, 1987). 
Transplant Society of Australia and New Zealand Code of Conduct for Living Liver Donation (Transplant Society of Australia and New Zealand, Sydney, 2004).

UNESCO Universal Declaration on Bioethics and Human Rights Adopted on 19 October 2005 by the $33^{\text {rd }}$ session of the General Conference of UNESCO.

United States Department of Health and Human Services Report of the Task Force on Organ Transplantation: Issues and Recommendations (United States Department of Health and Human Services, Washington DC, 1986).

Waitangi Tribunal Mangonui Sewerage Report (Waitangi Tribunal, Wellington, 1988).

Waitangi Tribunal Murwhenua Fishing Report (Waitangi Tribunal, Wellington, 1988).

Waitangi Tribunal The Taranaki Report (Waitangi Tribunal, Wellington, 1996).

Warnock Committee Report of the Committee of Inquiry into Human Fertilisation and Embryology (Cm 9314, HMSO, London, 1984).

World Health Organisation "Guiding Principles on Human Organ Transplantation" (1991) 337 Lancet 1470.

World Health Organisation and European Partnership on Patent's Rights and Citizen's Empowerment Genetic Databases: Assessing the Benefits and the Impact on Patients and Human Rights (WHO, Copenhagen, 2001).

World Medical Association Declaration of Helsinki: Recommendations Guiding Physicians in Biomedical Research Involving human Subjects Adopted by the $18^{\text {th }}$ World Medical Assembly, Helsinki, June 1964 and Adopted by the 18th WMA General Assembly, Helsinki, Finland, June 1964, and amended by the 29th WMA General Assembly, Tokyo, Japan, October 1975 35th WMA General Assembly, Venice, Italy, October 1983 41st WMA General Assembly, Hong Kong, September 1989 48th WMA General Assembly, Somerset West, Republic of South Africa, October 1996and the 52nd WMA General Assembly, Edinburgh, Scotland, October 2000 Note of Clarification on Paragraph 29 added by the WMA General Assembly, Washington 2002

Note of Clarification on Paragraph 30 added by the WMA General Assembly, Tokyo 2004

World Trade Organisation Declaration on the TRIPs Agreement and Public Health Doc. WT/MIN (01) Dec 2 (adopted 14 November 2001) $<$ http://www.wto.org $>$ (last accessed 15 May 2005).

\section{CONFERENCE PRESENTATIONS}

Durie, Mason "Mana Tangata: Culture Custom and Transgenic Research" (Deputy Vice-Chancellor's Lecture, Massey University, Wellington, 5 August 2003). 
Glover, M "Kaupapa Maori Health Research: A Developing Discipline" (Paper presented to the Hui Whakapiripiri, Whaiora Marae, Otara, Auckland, 1995).

Harris, John "The Rights to Choice in Founding a Family" (Paper presented to the Progress Educational Trust Conference: Chosen Children, 2003, Institute of Child Health, London, 2003).

Henare, M "Te tangata, te taonga, te hau: Maori Concepts of Property" (Paper presented to the Conference on Property and the Constitution, Wellington, for the Laws and Institutions in a Bicultural Society Research Project, Waikato University, 18 July 1998).

Mead, Aroha Te Pareake "How are the Values of Maori going to be Considered and Integrated in the Use of Plant Biotechnology in New Zealand?" (Paper presented to the Talking Technologies Conference on Plant Technology, Wellington, 8 May 1999).

Mead, Aroha Te Pareake "Understanding Maori Intellectual Property Rights" (Paper presented to the Inaugural Maori Legal Forum, Wellington, October 2002).

Parry, Bronwyn "From Bodies to Technological Artefacts: To What Does the New Human Tissue Bill Apply? Categorization issues and their implications." (Paper presented to the Human Tissue Conference, London, 2004).

Smith L "Toward Kaupapa Maori Research" ((Paper presented to the Matawhanui Conference, Maori University Teachers' Conference, Massey University, Palmerston North, 1995).

Solomon, Maui "Intellectual Property Rights and Indigenous Peoples Rights and Obligations"(Paper presented to the Global Biodiversity Forum 15 UNEP Headquarters, Gigiri, Nairobi, Kenya, May 2000). 